NILSON ALVES DE SOUZA

\title{
Gestão democrática e gestão financeira: o Programa de Transferência de Recursos Financeiros - PTRF - da cidade de São Paulo de 2006 a 2010
}

Dissertação apresentada à Faculdade de Educação da Universidade de São Paulo para obtenção do título de Mestre em Educação

Área de Concentração: Estado, Sociedade e Educação

Orientador: Prof. Dr. Rubens Barbosa de Camargo

São Paulo

2012 
AUTORIZO A REPRODUÇÃO E DIVULGAÇÃO TOTAL OU PARCIAL DESTE TRABALHO, POR QUALQUER MEIO CONVENCIONAL OU ELETRÔNICO, PARA FINS DE ESTUDO E PESQUISA, DESDE QUE CITADA A FONTE.

Catalogação na Publicação

Serviço de Biblioteca e Documentação

Faculdade de Educação da Universidade de São Paulo

379.5

S729g
Souza, Nilson Alves de

Gestão democrática e gestão financeira: o Programa de Transferência de Recursos Financeiros - PTRF - da cidade de São Paulo de 2006 a 2010 / Nilson Alves de Souza; orientação Rubens Barbosa de Camargo. São Paulo: s.n., 2012.

173 p. ils.; grafs.; tabs.; anexos

Dissertação (Mestrado - Programa de Pós-Graduação em Educação. Área de Concentração: Estado, Sociedade e Educação) - - Faculdade de Educação da Universidade de São Paulo.

1. Gestão democrática da educação 2. Financiamento da educação 3. Política educacional 4. Ensino (São Paulo) 5. Programa de Transferência de Recursos Financeiros I. Camargo, Rubens Barbosa de, orient. 
Nome: SOUZA, Nilson Alves de

Título: Gestão democrática e gestão financeira: o Programa de Transferência de Recursos Financeiros - PTRF - da cidade de São Paulo de 2006 a 2010

Dissertação apresentada à Faculdade de Educação da Universidade de São Paulo para obtenção do título de Mestre em Educação

Aprovado em:

Banca Examinadora

Prof. Dr. Instituição:

Julgamento: Assinatura:

Prof. Dr. Instituição:

Julgamento: Assinatura:

Prof. Dr. Instituição:

Julgamento: Assinatura: 

À minha mãe (in memoriam) por ter duvidado do meu fracasso escolar 



\section{AGRADECIMENTOS}

À Sylvie por ter me acompanhado em mais esse momento nas reflexões e nas crises. Pelo seu amor, carinho, atenção e solidariedade e por ter suportado o meu mau humor e pessimismo. Sem você seria impossível trilhar esse caminho.

Ao Prof. Dr. Rubens Barbosa de Camargo pela orientação cuidadosa, suas contestações fundamentais para o desenvolvimento da reflexão e o inspirador "toca o barco".

À Prof ${ }^{a}$ Dra. Lisete Regina Gomes Arelaro pelas valiosas contribuições na banca de qualificação, pelo dia-a-dia como exemplo de militância no comprometimento com a educação pública e pela carinhosa preocupação com o desenvolvimento da minha pesquisa.

Às Prof ${ }^{a}$ Andrea Barbosa Gouveia e Prof ${ }^{a}$ Dra. Maria Angélica Pedra Minhoto pelas preciosas contribuições apresentadas na banca de qualificação.

Aos entrevistados pela solidária e atenciosa disponibilidade.

Ao Gilson, à Nilza, ao Eufrásio e à Santa (in memoriam), minha família, pelo carinho, amor e compreensão das minhas ausências, vocês são fundamentais para mim.

À Vilma, Didier e Allan por ter aceitado esse "intruso" na família e me recebido tão bem com boa comida, boa bebida e ótimos momentos de descontração.

Ao Clóvis pela tradução do resumo para o inglês.

À Ana Paula e à Rosi pela leitura cuidadosa e imprescindíveis contribuições.

Aos Colegas do coletivo 212 e do coletivo 209 que direta ou indiretamente me auxiliaram na execução desse trabalho.

Aos Colegas de trabalho da EMEF Dr Sócrates Brasileiro por compartilharem comigo o "chão" da escola, por compreenderem algumas das minhas ausências e por estarem comigo na luta pela educação pública. 



\section{RESUMO}

SOUZA, N. A. Gestão democrática e gestão financeira: o Programa de Transferência de Recursos Financeiros - PTRF - na cidade de São Paulo de 2006 a 2009. 2012. 173 f. Dissertação (Mestrado) - Faculdade de Educação, Universidade de São Paulo, São Paulo, 2012.

Em meados de 2005, o governo municipal de São Paulo sancionou a Lei $\mathrm{n}^{\mathbf{0}} 13.991$ que criou o Programa de Transferência de Recursos Financeiros (PTRF), que consistia em transferir recursos financeiros do orçamento público por meio da Secretaria Municipal de Educação (SME) para as Associações de Pais e Mestres (APM). Essa política atendia o princípio, presente na LDB/96, de estabelecer para as escolas progressivo grau de autonomia de gestão financeira como meio para implementação da gestão democrática. O PTRF foi criado com a justificativa de ser um instrumento de ampliação da autonomia, de descentralização da administração e de participação da comunidade escolar nas tomadas de decisão nas escolas. Partindo do questionamento se o programa de fato fomentou a autonomia das escolas e em que medida criou meios para o fortalecimento da gestão democrática, esta pesquisa teve como objetivo geral analisar o PTRF da Prefeitura Municipal de São Paulo, no período de 2006 a 2010, buscando atingir dois objetivos específicos: 1) analisar se e como o PTRF pode ser uma forma de incentivo à democratização da gestão escolar e quais as repercussões do programa no cotidiano escolar e sua relação com as tomadas de decisão e 2) analisar os usos dos recursos para viabilizar o projeto político pedagógico e a relação do planejamento pedagógico com o planejamento dos gastos dos recursos. Como fundamentação teórica a pesquisa apoiouse em autores que debatem conceitos de democracia e gestão democrática, principalmente Bobbio (2009), Paro (2002), Coutinho (2000) e Benevides (1994). O estudo, de caráter qualitativo, contou com revisão bibliográfica, análise documental e entrevistas semiestruturadas em três escolas da rede municipal de São Paulo - uma creche, uma pré-escola e uma escola de ensino fundamental. O estudo permitiu traçar um panorama do Programa dentro da Secretaria Municipal de Educação de São Paulo e considerações sobre a implementação do mesmo em escolas da rede. Foi possível constatar que, no período estudado, o Programa não teve grande representação dentro do orçamento da Secretaria Municipal de Educação (menor que 1\%), sendo a taxa de crescimento dos recursos financeiros destinados para o programa inferior à taxa de crescimento dos recursos para a educação no município. As análises documentais das escolas e as entrevistas com seus profissionais demonstraram que os recursos descentralizados ajudam no desenvolvimento de suas atividades, mas são insuficientes para atender suas necessidades. Destaca-se ainda que os tramites burocráticos e a insuficiência do quadro de profissionais das escolas são dificultadores para utilização dos recursos.

Palavras-chave: Gestão democrática; gestão financeira; política educacional; Programa de Transferência de Recursos Financeiros; rede municipal de educação de São Paulo. 



\begin{abstract}
SOUZA, N. A. Democratic management and financial management: the Transfer Program of Financial Resources - PTRF - of the city of São Paulo from 2006 to 2010. 2012. 173 f. Dissertação (Mestrado) - Faculdade de Educação, Universidade de São Paulo, São Paulo, 2012.

In the middle of 2005, the city hall of São Paulo signed law 13,991 that established the Transfer Program of Financial Resources $(\boldsymbol{P T R F})$. This program was to transfer funds from the public budget by the Municipal Secretariat Education to the Parent-Teacher Associations and served the principle present in Education Law (LDB/96), to establish schools for progressive degree of autonomy of financial management as a way to implement democratic management. The PTRF was created as a justification to be an instrument of expansion of autonomy, decentralization of administration and school community participation in decision making in schools. Thus, this research questioned: the program actually promoted the autonomy of schools? And to what extent has created means for strengthening the democratic management? The overall objective was to analyze PTRF of Sao Paulo in the period 2006 to 2010 to examine two specific goals: 1) as the PTRF can be a way to encourage the democratization of school management, its impact and its relationship to decisions in everyday school 2) the uses of resources to enable the teaching plan and its relation with the planning of the expenditures of funds. To achieve these objectives this research consisted of a literature review, document analysis and semi-structured interviews in three public schools in the city of São Paulo (a daycare, a preschool and an elementary school) and relied on authors mainly Bobbio (2009), Paro (2002), Coutinho (2000) and Benevides (1994) as theoretical debate on the concepts of democracy and democratic management. Therefore this research drew a picture of the PTRF City Department of Education of Sao Paulo and made considerations about the scope of $\boldsymbol{P T R \boldsymbol { F }}$ in municipal schools. It was found that in the period studied, the PTRF not had great representation in the budget of the Municipal Education (less than $1 \%$ ), and the rate of growth of financial resources earmarked for the program was less than the growth rate of financial resources for education in the county and the result of the analysis of school documents and interviews with its employees demonstrated that decentralized financial help in the development of their daily activities, but they are insufficient to meet their needs. In conclusion still stands that bureaucratic procedures and lack of professional staff in schools are obstacles to the use of financial resources.
\end{abstract}

Keywords: democratic management; financial management; educational policy; Transfer program of financial resources; Municipal Educational System of São Paulo. 



\section{LISTA DE SIGLAS}

APM

BM

CCM

CECI

CEI

CEIJA

CEU

CF/88

CNPJ

CPF

CRECE

DCTF

DIPJ

DIRF

DRE

EF

EI

EMEE

EMEF

EMEFEM

EMEI

EUA

FGV

FMI

FNDE

FNDE/CD

GFIP

IGP-M

INEP

LDB

LOA

LOM

MDE

NA

NPC

PCdoB

PDDE

PDT
Associação de Pais e Mestres

Banco Mundial

Cadastro do Contribuinte Mobiliário

Centro de Educação e Cultura Indígena

Centro de Educação Infantil

Centro Integrado de Educação de Jovens e Adultos

Centro Educacional Unificado

Constituição Federal de 1988

Cadastro Nacional de Pessoa Jurídica

Cadastro de Pessoa Física

Colegiado Regional de Representantes de Conselhos de Escola

Declaração de Débitos e Créditos Tributários Federais

Declaração de Isenção de Imposto de Renda Pessoa Jurídica

Declaração do Imposto Retido na Fonte

Diretoria Regional de Ensino

Ensino Fundamental

Educação Infantil

Escola Municipal de Educação Especial

Escola Municipal de Ensino Fundamental

Escola Municipal de Ensino Fundamental e Ensino Médio

Escola Municipal de Educação Infantil

Estados Unidos da América

Fundação Getúlio Vargas

Fundo Monetário Internacional

Fundo Nacional de Desenvolvimento da Educação

Fundo Nacional de Desenvolvimento da Educação/Conselho Deliberativo

Guia de Recolhimento do Fundo de Garantia por Tempo de Serviço e Informações à Previdência Social

Índice Geral de Preços do Mercado

Instituto Nacional de Estudos e Pesquisas Educacionais Anísio

Teixeira

Lei de Diretrizes e Bases da Educação Nacional

Lei Orçamentária Anual

Lei Orgânica do Município

Manutenção e Desenvolvimento do Ensino

Número de Alunos Matriculados

Núcleo de Planejamento Central

Partido Comunista do Brasil

Programa Dinheiro Direto na Escola

Partido Democrático Trabalhista 


\begin{tabular}{ll} 
PL & Projeto de Lei \\
PMDB & Partido do Movimento Democrático Brasileiro \\
PMDE & Programa de Manutenção e Desenvolvimento do Ensino \\
PMSP & Fundamental \\
PT & Prefeitura Municipal de São Paulo \\
PTB & Partido dos Trabalhadores \\
PTRF & Partido Trabalhista Brasileiro \\
RAIS & Programa de Transferência de Recursos Financeiros \\
RCEM & Relação Anual de Informações Sociais \\
RG & Regime Comum das Escolas Municipais \\
SEMPLA & Registro Geral \\
SF & Secretaria Municipal de Planejamento, Orçamento e Gestão \\
SIMCE & Secretaria Municipal de Finanças \\
SINPEEM & Sistemas de Medicíon de la Calidad de la Educacion de Chile \\
& Sindicato dos Profissionais em Educação no Ensino Municipal de \\
SME & São Paulo \\
SUTEM & Secretaria Municipal de Educação \\
TFE & Subsecretaria do Tesouro Municipal \\
TIMSS & Taxa de Fiscalização do Estabelecimento \\
UE & Trends in International Mathematics and Science Study \\
UEx & Unidade Educacional \\
VF & Unidade Executora \\
VV & Valor Fixo \\
\hline
\end{tabular}




\section{LISTA DE QUADROS}

Quadro 1 - Classificação do Banco Mundial para programas de descentralização...................51

Quadro 2 - Levantamento da regulamentação do PTRF ...................................................... 76

Quadro 3 - Fórmula do cálculo para repasse do PTRF, por ano............................................. 93

Quadro 4 - Perfil dos entrevistados membros do CE ou APM das escolas-campo ................ 104

Quadro 5- Despesas em pedagógico e não pedagógico com recursos do PTRF do CEI, por

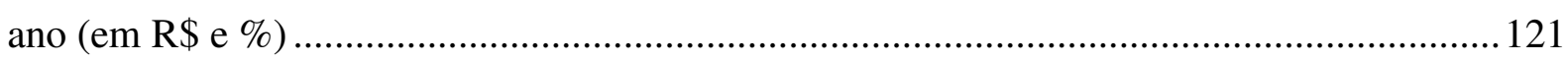

Quadro 6- Despesas em pedagógico e não pedagógico com recursos do PTRF da Emei, por

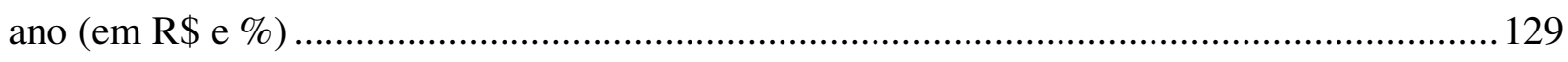

Quadro 7- Despesas em pedagógico e não pedagógico com recursos do PTRF da Emef, por

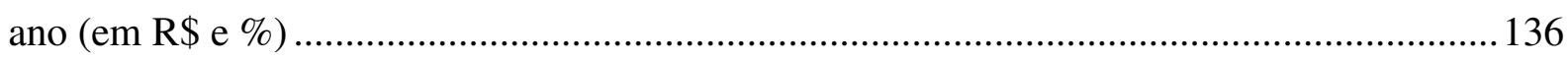





\section{LISTA DE TABELAS}

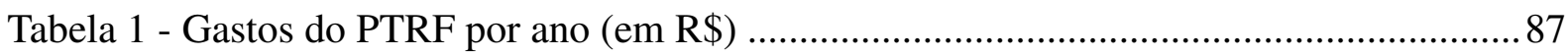

Tabela 2 - Relação do PTRF com as despesas em educação, por ano (em R\$ e \%). ...............89

Tabela 3 - Despesas do PTRF na educação infantil e no ensino fundamental por ano (em R\$ e

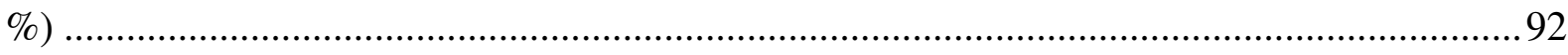

Tabela 4 - Valores totais do PTRF, por ano, e valor por aluno/por ano, 2010 …....................97

Tabela 5 - Despesas do PTRF por categoria econômica, por ano (em R \$ e \%) .......................99

Tabela 6 - Cálculo para repasse dos recursos do PDDE para as regiões sul e sudeste e o

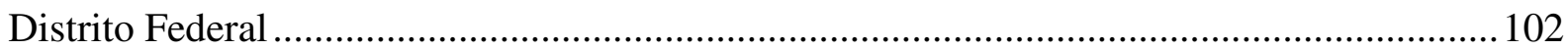

Tabela 7 - Número de reuniões dos CEs e APMs (2006-2010) .............................................. 106

Tabela 8 - Número de reuniões dos CEs e APMs que trataram do PTRF (2006-2010) ......... 106

Tabela 9 - Recursos financeiros recebidos do PTRF pelo CEI, por ano (em R\$) .................. 116

Tabela 10 - Despesas realizadas com recursos do PTRF pelo CEI, por ano (em R\$ e \%) ..... 116

Tabela 11 - Recursos financeiros recebidos do PTRF pela Emei, por ano (em R\$ e \%) ....... 124

Tabela 12 - Despesas realizadas com recursos do PTRF pela Emei, por ano (em R\$ e \%) ... 124

Tabela 13 - Recursos financeiros recebidos do PTRF pela Emef, por ano (em R\$ e \%) ........131

Tabela 14 - Despesas realizadas com recursos do PTRF pela Emef, por ano (em R\$ e \%) ... 132

Tabela 15 - Receitas totais e por aluno do PTRF, no CEI, na Emei e na Emef, por ano (em R\$)

Tabela 16 - Despesas totais e por aluno do PTRF, no CEI, na Emei e na Emef, por ano (em $\mathrm{R} \$)$

Tabela 17 - Despesas totais e por aluno do PTRF, em pedagógico, no CEI, na Emei e na Emef, por ano (em R\$) 



\section{LISTA DE GRÁFICOS}

Gráfico 1 - Taxa de crescimento das despesas em educação e do PTRF, por ano (em \%).......90

Gráfico 2 - Comportamento dos montantes de recursos, segundo os critérios para 2009 (em

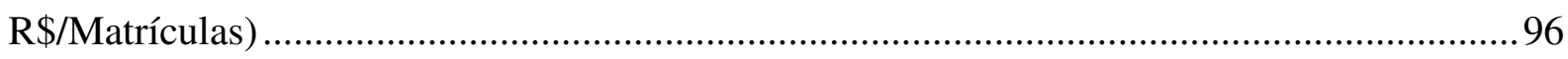

Gráfico 3 - Comportamento dos montantes de recursos, segundo os critérios para 2010 (em

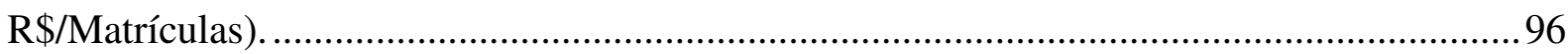

Gráfico 4 - Despesas com o PTRF e com o PDDE, por ano (em R\$) ……............................. 101

Gráfico 5 - Receita, gasto e saldo reprogramado dos recursos do PTRF do CEI por ano (em $\mathrm{R} \$)$

Gráfico 6 - Montantes de recursos gastos do PTRF por tipo de despesa no CEI, por ano (em

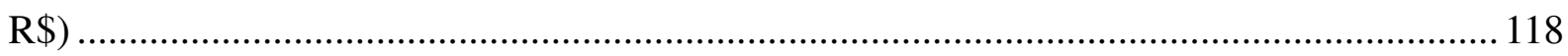

Gráfico 7 - Recursos gastos do PTRF por tipo de despesa do CEI, por ano (em \%) ............. 119 Gráfico 8 - Despesas pedagógicas e não pedagógicas com recursos do PTRF do CEI, por ano

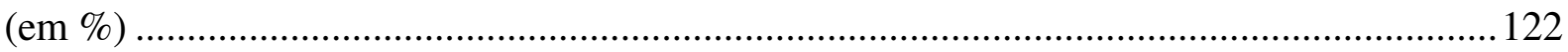

Gráfico 9 - Receita, gasto e saldo reprogramado dos recursos do PTRF da Emei, por ano (em $\mathrm{R} \$)$

Gráfico 10 - Montante de recursos gastos do PTRF por tipo de despesa na Emei, por ano (em

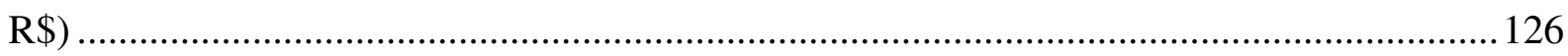

Gráfico 11- Recursos gastos do PTRF por tipo de despesa da Emei, por ano (em \%)........... 127 Gráfico 12- Despesas pedagógicas e não pedagógicas com recursos do PTRF na Emei, por ano (em \%). 130

Gráfico 13 - Receita, gasto e saldo reprogramado dos recursos do PTRF da Emef, por ano (em $\mathrm{R} \$)$

Gráfico 14 - Montante de recursos gastos do PTRF por tipo de despesa na Emef, por ano (em $\mathrm{R} \$)$

Gráfico 15 - Recursos gastos do PTRF por tipo de despesa da Emef, por ano (em \%) 134

Gráfico 16 - Despesas pedagógicas e não pedagógicas com recursos do PTRF na Emef, por ano $(\mathrm{em} \%)$. 



\section{Sumário}

INTRODUÇÃ

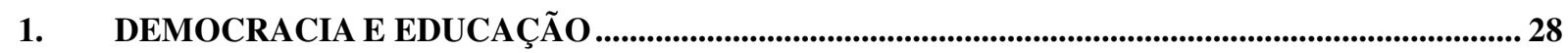

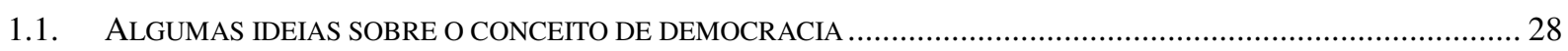

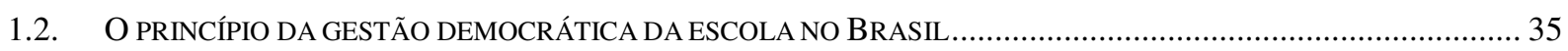

2. POLÍTICAS DE DESCENTRALIZAÇÃ

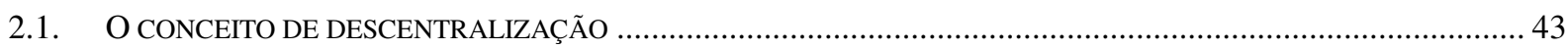

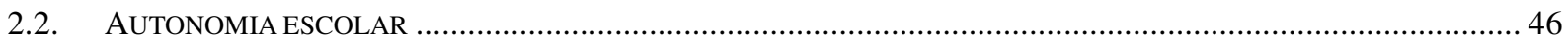

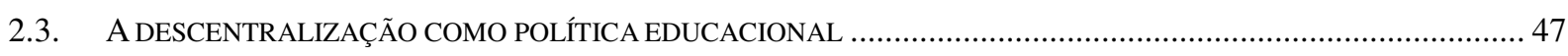

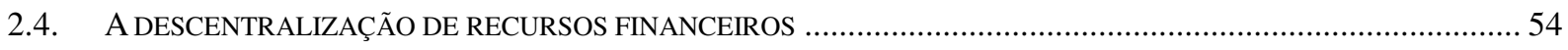

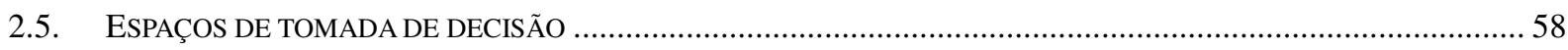

3. O PROGRAMA DE TRANSFERÊNCIA DE RECURSOS FINANCEIROS DA PMSP ................... 70

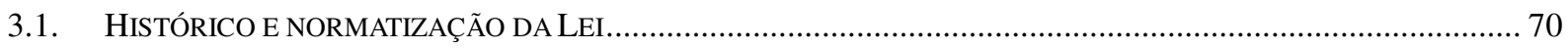

3.2. PROCEDIMENTOS PARA RECEBIMENTO DOS RECURSOS E PRESTAÇ̃̃o DE CONTAS ......................................... 79

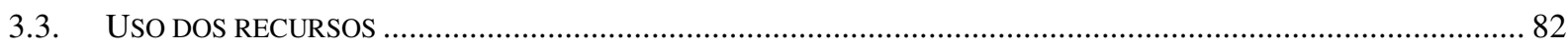

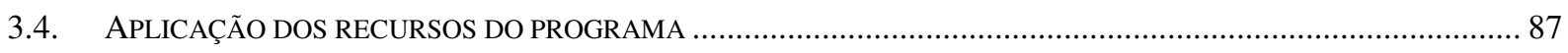

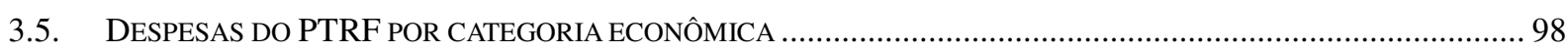

3.6. OUTRAS FORMAS DE DESCENTRALIZAÇÃO DE RECURSOS E O PTRF......................................................... 100

4. AS ESCOLAS PESQUISADAS E O PTRF ......................................................................................... 103

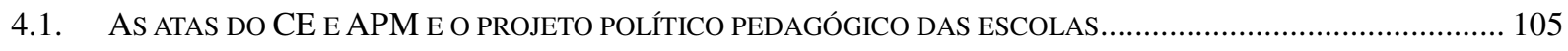

4.2. ANÁLISE DOS RECURSOS FINANCEIROS E GASTOS DO PTRF DAS ESCOLAS.................................................. 115

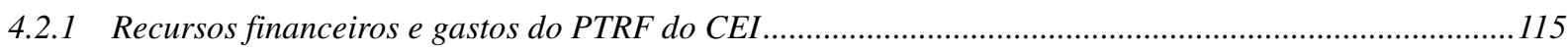

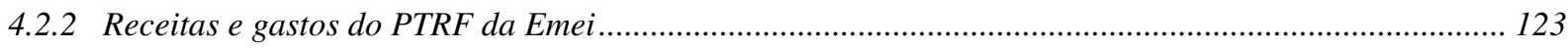

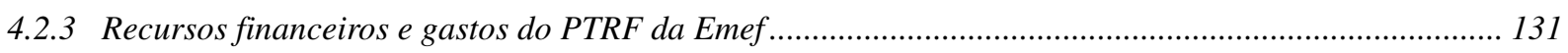

4.2.4 Algumas comparações sobre os recursos do PTRF e seus usos no CEI, na Emei e na Emef................... 138

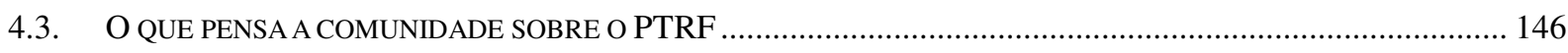

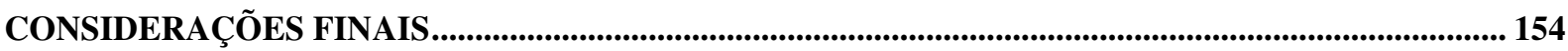

REFERÊNCIAS BIBLIOGRÁFICAS....................................................................................................... 161

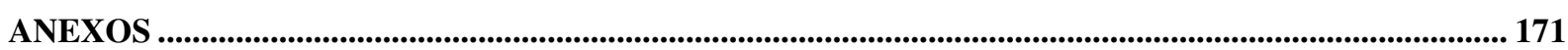





\section{INTRODUÇÃO}

Ao fim do período de ditadura militar no Brasil, os movimentos sociais, até então sufocados pela repressão, intensificaram suas lutas, tornando-se cada vez mais imperiosa a necessidade de ampliar as possibilidades de participação dos cidadãos em nosso país. Decorrente disso o texto da Constituição Federal de 1988 (CF/88) trouxe vários elementos no intuito de garantir as liberdades democráticas e a participação popular, embora muitas questões tenham trazido formulações aquém das reivindicações dos movimentos devido à ação dos setores mais conservadores. Uma demonstração dessa situação está presente no art. 206: "O ensino será ministrado com base nos seguintes princípios: [...] VI - gestão democrática do ensino público, na forma da lei" (BRASIL, 1988).

A CF/88 não estabeleceu como seria implementado o princípio de gestão democrática nos sistemas e unidades de ensino do Brasil, subentendendo-se que ficou a cabo de cada sistema de ensino proceder da forma que achasse mais conveniente. Evidentemente, houve experiências interessantes que inclusive pautaram a questão nas discussões nacionais acerca do tema.

Em 1996, foi aprovada a Lei de Diretrizes e Bases da Educação Nacional, Lei Federal $\mathrm{n}^{\text {o }} 9.394$ (LDB/96). No texto da LDB/96 novamente estava presente o princípio da gestão democrática, que estabeleceu:

\footnotetext{
Art. 14. Os sistemas de ensino definirão as normas da gestão democrática do ensino público na educação básica, de acordo com as suas peculiaridades e conforme os seguintes princípios:

I - participação dos profissionais da educação na elaboração do projeto pedagógico da escola;

II - participação das comunidades escolar e local em conselhos escolares ou equivalentes.

Art. 15. Os sistemas de ensino assegurarão às unidades escolares públicas de educação básica que os integram progressivos graus de autonomia pedagógica e administrativa e de gestão financeira, observadas as normas gerais de direito financeiro público. (BRASIL, 1996)
}

Apoiado nesses artigos da LDB/96, em 10 de julho de 2005, o governo municipal de São Paulo sancionou a Lei $n^{\circ} 13.991$, que criou o Programa de Transferência de Recursos Financeiros (PTRF), que consiste em transferir recursos financeiros do orçamento público por meio da Secretaria Municipal de Educação (SME) para as Associações de Pais e Mestres (APM) de suas unidades escolares. 
A lei foi aprovada com a justificativa de que o PTRF seria um instrumento de ampliação da autonomia, de descentralização da administração e de participação da comunidade escolar nas tomadas de decisão nas unidades escolares. Para tanto, os recursos foram destinados às despesas de custeio, tais como manutenção dos equipamentos existentes, aquisição de material de consumo necessário ao funcionamento da unidade educacional, manutenção, conservação e pequenos reparos da unidade educacional, desenvolvimento de atividades educacionais, implementação de projetos pedagógicos da unidade educacional, contratação de serviços e despesas de capital, na forma de pequenos investimentos a serem aplicados na aquisição de material permanente.

Esta pesquisa pretende analisar a implantação do PTRF na rede municipal de ensino de São Paulo, no período de 2006 a 2010, à luz do princípio da gestão democrática. A presente pesquisa, parte do questionamento se o programa de fato fomenta a autonomia das escolas e em que medida cria meios para o fortalecimento da gestão democrática por meio da investigação de como são efetivadas as tomadas de decisão dentro das escolas municipais a respeito da utilização da verba destinada pelo PTRF.

Assim sendo, essa pesquisa tem como objetivo geral analisar o Programa de Transferência de Recursos Financeiros (PTRF) da Prefeitura Municipal de São Paulo, no período de 2006 a 2010, na perspectiva de discutir os processos de democratização da gestão e a constituição da autonomia da escola. A fim de realizar essa tarefa estabeleceram-se dois objetivos específicos: 1) analisar em que medida o PTRF pode ser uma forma de incentivo à democratização da gestão escolar e quais as repercussões do programa no cotidiano escolar e sua relação com a tomada de decisão; e 2) analisar os usos dos recursos para viabilizar o projeto político pedagógico e a relação do planejamento pedagógico com o planejamento dos gastos dos recursos.

Por se tratar de um programa relativamente novo é possível analisá-lo praticamente de seu início. O período de cinco anos permite acompanhar como tem se desenhado essa política e as adaptações realizadas nesses anos iniciais. A exclusão do primeiro ano, 2005, que teve um único repasse para as unidade escolares, tem como razão a dificuldade de localizar os documentos desse ano nas escolas e por não constar nos demonstrativos de despesas os gastos do PTRF, pois sua aprovação foi no decorrer do ano de exercício do orçamento, o que significa posterior a aprovação da Lei Orçamentária Anual (LOA) do município do ano em questão. 
Como o problema em questão trata de tema relacionado ao financiamento da educação, coletaram-se dados do orçamento municipal no período de 2006 a 2010. Verificaram-se os montantes orçados e executados com o programa, a distribuição dos recursos por categoria econômica, a taxa de crescimento do orçamento para a educação, a taxa de crescimento dos recursos para o PTRF e a relação entre os montantes do PTRF e do Programa Dinheiro Direto na Escola $\left(\mathrm{PDDE}^{1}\right)$. Também, analisaram-se os critérios de cálculo dos repasses e seus desdobramentos.

Para o estudo foram selecionadas três escolas da rede municipal de São Paulo: 1 (uma) creche, que no município de São Paulo tem a denominação de Centro de Educação Infantil (CEI), 1 (uma) pré-escola, denomidas de Escola Municipal de Educação Infantil (Emei) e 1 (uma) Escola Municipal de Ensino Fundamental (Emef). A opção por esses tipos de escolas se deu pela razão do PTRF usar valores diferenciados (tanto o valor fixo como o valor por aluno) para o cálculo dos recursos por tipo de escola. Esses não são os únicos tipos de escolas existentes na rede municipal de São Paulo, mas abrange quase todos os critérios de cálculos dos recursos. As três escolas selecionadas para estudo de campo pertencem a um Centro Unificado Educacional (CEU). Os CEUs, criados a partir de 2003, são equipamentos públicos compostos por um CEI, uma Emei e uma Emef e núcleos de cultura, esporte e lazer e de educação, que promovem ações para a comunidade local, não necessariamente pertencente às escolas.

A opção por escolas de um mesmo CEU se deu pelo fato de reduzir variáveis que implicam os gastos das escolas, como por exemplo, o tempo de funcionamento das escolas. Ponderou-se também que pelo fato das escolas estarem localizadas no mesmo espaço as características socioeconômicas do público atendido seriam semelhantes.

Com o objetivo de auxiliar a compreensão da organização do programa e seu processo de tomada de decisão no âmbito da SME, realizou-se entrevista com a Presidente da Comissão Técnica do PTRF a Sra. Sônia Regina Amaral Caldas Medeiros. A comissão tem como objetivo orientar, receber, analisar e auditar as prestações de contas das Diretorias Regionais de Ensino.

Como recursos de investigação foram realizadas também entrevistas com membros do Conselho de Escola (CE) e da APM e com um dos membros das equipes gestoras das

\footnotetext{
${ }^{1}$ O PDDE, criado pelo governo federal em 1995, tem como objetivo transferir recursos orçamentários da União para as escolas de ensino fundamental das redes estaduais e municipais, e escolas especiais mantidas por organizações não governamentais sem fins lucrativos.
} 
unidades educacionais. Para investigar os processos de tomada de decisão foram analisadas as atas do Conselho de Escola e da APM, a documentação própria do programa e o Projeto Político Pedagógico de cada unidade. Far-se-á também análise das prestações de contas dessas escolas no período de 2006 a 2010, com o intuito de compreender a realização dos gastos nas escolas.

Realizou-se estudo bibliográfico a respeito do tema democracia, gestão democrática, o conceito de descentralização e os programas de transferência de recursos financeiros para as unidades escolares. Contudo, é indispensável ressaltar que este levantamento bibliográfico teve por objetivo subsidiar a análise do trabalho e não promover um "estado da arte" do tema. Também se levantou a legislação federal e municipal sobre descentralização de recursos financeiros para as escolas, mais especificamente sobre o Programa de Transferência de Recursos Financeiros.

Esta dissertação conta com quatro capítulos mais as considerações finais. O capítulo 1, intitulado "democracia e educação", apresenta algumas ideias sobre o conceito de democracia em autores que examinaram a temática. Com base em textos de Norberto Bobbio (2009) e Carlos Nelson Coutinho (2000) procura elencar importantes elementos ao processo de democratização. Reconhecendo estreita ligação entre o conceito de cidadania e de democracia, busca também apresentar uma discussão sobre o conceito de participação e como ele tem se apresentado no Brasil. O mesmo capítulo também analisa o princípio da gestão democrática na Constituição Federal de 1988 e na Lei de Diretrizes e Bases da Educação Nacional.

No segundo capítulo são discutidas as políticas de descentralização para a educação. Nesse sentido, apresenta uma conceituação do termo descentralização a fim compreender melhor as questões que o cercam, algumas características e suas tipologias. A discussão sobre descentralização envolve também a questão da autonomia, no caso a escolar, por isso são feitas algumas considerações referentes à autonomia escolar. Nesse capítulo há ainda uma descrição de como as políticas de descentralização têm ocorrido mundialmente à luz das orientações dos órgãos multilaterais, como o Banco Mundial, e ao final discute os espaços de tomada de decisão na escola. Para isso é analisado brevemente o papel dos CE e da APM.

O Capítulo 3 se dedica a detalhar o PTRF e analisá-lo. Inicialmente é descrito o histórico e normatização do programa de forma a possibilitar ao leitor a compreensão sobre as complexidades que cercam essa política. Em seguida, por se tratar de um repasse de recursos financeiros às Associações de Pais e Mestres (APMs), examinam-se os procedimentos e 
exigências para recebimento dos recursos oriundos do programa, bem como a forma de prestação de contas à qual estão sujeitos, com a descrição dos gastos possíveis de serem realizados. Considerando a rede como um todo, o capítulo analisa também a aplicação dos recursos, de forma a levantar os montantes aplicados nos anos de $2006^{2}$ a 2010 . Foram também analisados os gastos por categorias econômicas (de capital e de custeio) e a relação do PTRF com outros recursos financeiros descentralizados às unidades escolares.

O capítulo quatro faz análise dos dados obtidos a partir da pesquisa de campo. $\mathrm{O}$ capítulo está dividido em três partes. O primeiro, diz respeito à análise dos documentos próprios das escolas, sendo eles as atas de reunião das APMs e dos CEs. A segunda parte foca nos dados financeiros das escolas coletados dos processos de prestação de contas das escolas. Por último, o que pensa a comunidade sobre o PTRF. Neste capítulo buscou-se dialogar os dados conseguidos seja por meio dos documentos próprios das escolas ou dos documentos das prestações de contas com as entrevistas realizadas com os representantes dos CE ou das APM.

Por fim, as considerações finais apresentam um apanhado das análises realizadas com base nos resultados alcançados pela pesquisa. Sugere-se também abrir uma discussão sobre alternativas de mudanças necessárias no programa no sentido de contribuir para aprimorar o processo de democratização da gestão escolar.

\footnotetext{
${ }^{2}$ Como o programa foi criado em 2005, somente a partir dos demonstrativos orçamentários de 2006 que estão identificadas as despesas do PTRF, mesmo tendo sido realizadas despesas no programa no seu primeiro ano.
} 


\section{DEMOCRACIA E EDUCAÇÃO}

Tem-se por objetivo neste capítulo percorrer algumas das ideias presentes na construção do conceito de democracia. Evidentemente não se fará uma análise pormenorizada de seus conceitos fundamentais a fim de esgotar a temática ou acompanhar seu percurso histórico, mas substanciar a discussão deste trabalho de pesquisa, que pode ser resumida em: qual o papel que a descentralização de recursos financeiros ocupa no processo de democratização da educação de forma mais abrangente e da gestão escolar de forma específica?

Nesse sentido, será analisado também o princípio da gestão democrática na Constituição Federal de $1988(\mathrm{CF} / 88)$ e na Lei de Diretrizes e Bases da Educação Nacional, Lei no 9.394/96, (LDB/96) e as considerações de alguns autores sobre o tema da gestão democrática nas escolas.

\subsection{Algumas ideias sobre o conceito de democracia}

Bobbio em seu trabalho "O futuro da democracia: uma defesa das regras do jogo", com o intuito de construir uma definição mínima de democracia afirma que:

[...] o único modo de se chegar a um acordo quando se fala de democracia, entendida como contraposta a todas as formas de governo autocrático, é o de considerá-la caracterizada por um conjunto de regras (primárias ou fundamentais) que estabelecem quem está autorizado a tomar as decisões coletivas e com quais procedimentos. (BOBBIO, 2009, p. 30, grifo do autor)

Para Bobbio (2009) há três condições essenciais que julga necessárias para aceitar uma definição mínima de democracia: a) número elevado de participantes nas decisões; b) regras de procedimento na tomada de decisão e c) condições reais para decidir.

A condição "número elevado de participantes nas decisões" tem como premissa que todos os grupos sociais são obrigados a tomar decisões que recaem a todos do grupo, com o objetivo de garantir a sobrevivência do mesmo. As decisões coletivas são tomadas por indivíduos não podendo o coletivo em si tomá-las, porque este não é algo único e sim um conjunto de indivíduos, então para que sejam aceitas é necessário haver regras que estabeleçam quem tem autorização para tomar as decisões. A democracia é característica por 
conceder a um maior número de pessoas essa autorização e de tomar decisões vinculatórias para o grupo. A regra de procedimento na tomada de decisão na democracia é a regra da maioria. Mas se a posição da maioria é aceita como decisão de forma vinculatória a todos, maior é a aceitação da aprovação por unanimidade, sendo que essa somente se efetiva em grupos restritos ou homogêneos. A unanimidade é um recurso para dois casos, quando se trata de decisão muito grave onde qualquer um do grupo tem o poder de veto ou quando se trata de questão de menor importância e membros em desacordo não se manifestam expressamente. Por último, os membros autorizados a decidir tem que possuir condições reais de escolha, ou seja, garantia de liberdade de opinião, de expressão de suas opiniões, de reunir-se e de associação. O autor afirma que "as normas constitucionais que atribuem estes direitos não são exatamente regras do jogo: são regras preliminares que permitem o desenrolar do jogo" (BOBBIO, 2009, p. 32).

Bobbio trata nesse mesmo trabalho de uma questão muito importante para a discussão sobre a descentralização de recursos financeiros, os espaços de decisão para a democracia. Com a elevada intensificação da complexidade dos Estados modernos revela-se a impossibilidade da participação direta dos indivíduos em todas as decisões vinculatórias ao grupo social, que contraditoriamente poderia ocasionar apatia. Considerando o sufrágio universal já alcançado, o autor transpõe a questão da quantidade para qualidade quando diz:

[...] quando se deseja saber se houve um desenvolvimento da democracia num dado país, o certo é procurar perceber se aumentou não o número dos que têm o direito de participar nas decisões que lhes dizem respeito, mas os espaços nos quais podem exercer este direito. (Ibid., p. 40)

Quando Bobbio se refere à expansão dos espaços de participação como ampliação do processo de democratização está considerando uma passagem da democracia política para a democracia social, que considera os cidadãos em seus múltiplos papeis sociais.

Com uma expressão sintética pode-se dizer que, se hoje se pode falar de processo de democratização, ele consiste não tanto, como erroneamente muitas vezes se diz, na passagem da democracia representativa para a democracia direta quanto na passagem da democracia política em sentido estrito para a democracia social, ou melhor, consiste na extensão do poder ascendente, que até agora havia ocupado quase exclusivamente o campo da grande sociedade política (e das pequenas minúsculas, em geral politicamente irrelevantes associações voluntárias), para o campo da sociedade civil nas suas várias articulações, da escola à fábrica. (Ibid., p.67) 
Coutinho (2000) em seu trabalho "Contra a Corrente: Ensaios sobre a democracia e o socialismo" considera a democracia um valor universal. Coutinho define valor não como "norma abstrata e intemporal" onde ignoraria o contexto histórico. Pelo contrário, para sustentar essa ideia recorre à definição de Agnes Heller. Que entendemos por valor? Tudo o que faz parte do ser genérico do homem e
contribui, direta e indiretamente, para a explicitação desse ser genérico [...]. Pode-se
considerar "valor" tudo o que, em qualquer das esferas [do ser social] e em relação à
situação de cada momento, contribua para o enriquecimento daqueles componentes
essenciais. [...] O valor, portanto, é uma categoria ontológico-social e, como tal, é
algo objetivo [...], independente das avaliações dos indivíduos, mas não da atividade
dos homens, pois é expressão e resultado de relações e situações sociais. (HELLER,
$1972^{3}$ apud COUTINHO, 2000, p. 22)

Coutinho (2000) diz que o conjunto de objetivações da democracia é produzido ao longo do tempo e em processo de transformação e desenvolvimento, assim sendo, a define como democratização, pois parte da premissa que a ontologia da democracia é processual e não um estado. Acrescenta o universal ao valor por entender que as objetivações da democracia podem perfeitamente se desenvolver tanto em formações socioeconômicas capitalistas quanto socialistas.

Para ilustrar a universalidade da democracia como valor, Coutinho exemplifica que no capitalismo algumas liberdades democráticas ou instituições democráticas perduram mesmo em oposição às vontades da burguesia por meio das lutas da classe trabalhadora. Já para as experiências socialistas, mesmo considerando um processo de "unificação social" gerado pelo fim (processual) das classes, não encontraremos uma "homogeneização" total, assim é necessário garantir também uma forma de procedimento, emprestando o termo de Bobbio, para a representação política da diversidade (COUTINHO, 2000).

Então, a democracia apresenta-se como essencial para uma construção progressista seja em qual for a ordem econômico-social. Observa-se que a democracia, ou melhor, a democratização é um valor essencial na transformação da sociedade que vivemos no sentido de construir uma sociedade não mais pautada pela acumulação de capital, mas pela emancipação do homem, que se pode chamar genericamente de socialismo.

Contudo, como alerta Coutinho, não se deve concluir que a democracia socialista será uma sequência da democracia liberal. Acredita o autor que novos institutos políticos serão

${ }^{3}$ Heller, Agnes. O cotidiano e a história. Rio de Janeiro: Paz e Terra, 1972. 
criados ou desenvolvidos a partir do que hoje ainda são experiências muito primárias e que outros institutos devem ser revistos e alterados, como os parlamentos (COUTINHO, 2000).

Bobbio faz uma diferenciação entre democracia representativa e Estado parlamentar.

\begin{abstract}
A expressão "democracia representativa" significa genericamente que as deliberações coletivas, isto é, as deliberações que dizem respeito à coletividade inteira, são tomadas não diretamente por aqueles que dela fazem parte mas por pessoas eleitas para esta finalidade. Ponto e basta. O estado parlamentar é uma aplicação particular, embora relevante do ponto de vista histórico, do princípio da representação [...].

De resto, não existe hoje nenhum estado representativo em que o princípio da representação concentre-se apenas no parlamento: os estados que hoje nos habituamos a chamar de representativos [...] está estendido também as regiões. (BOBBIO, 2009, p. 44)
\end{abstract}

As organizações populares (partidos, sindicatos, organizações de bairro, organizações culturais etc.) geram uma força "de baixo para cima”, em movimento contra-hegemônico no interior da sociedade civil. Coutinho (2000) considera essas organizações populares como novos "sujeitos políticos coletivos". Para o autor, a formação dos sujeitos políticos coletivos está relacionada ao processo de socialização das forças produtivas e ocorre em dois níveis. O primeiro nível, devido à crescente divisão do trabalho, provoca em contraposição o agrupamento de pessoas em função da defesa de seus direitos. O segundo, o aumento da produtividade social do trabalho possibilitou a redução da jornada de trabalho o que implicou o aumento de tempo livre do trabalhador atendendo um condicionante para a organização dos trabalhadores ${ }^{4}$.

Os Estados liberais apresentaram tardiamente o reconhecimento da cidadania e sua concretude mínima para o exercício da democracia.

Embora, as "Declarações de Direitos Humanos" tenham afirmado, desde o século XVIII, a soberania popular - ou, em outras palavras, a extensão da cidadania a todos os membros do corpo social -, a efetiva socialização da política ocorreu tardiamente nos Estados liberais capitalistas. $\mathrm{Na}$ prática, os primeiros regimes liberais restringiram tanto o direito de associação quanto o de sufrágio, limitando as franquias políticas à camada dos proprietários. (COUTINHO, 2000, p. 26)

O sufrágio universal masculino somente foi alcançado no final do século XIX e começo do século XX (o feminino mais tardiamente) e a liberdade associativa em sindicatos

\footnotetext{
${ }^{4}$ A redução da jornada de trabalho a qual o autor se refere retoma os tempos da Revolução Industrial, sendo que ainda hoje está nas bandeiras de lutas dos trabalhadores a redução da jornada de trabalho.
} 
foi negada em favor do princípio liberal de liberdade de mercado por muito tempo (COUTINHO, 2000).

Coutinho (2000) descreve que os movimentos associativos não foram limitados àqueles que faziam parte da classe operária, mas também a setores médios assalariados, camponeses e, inclusive, aqueles que compunham a burguesia tiveram que se organizar por fora do Estado.

Um dos elementos indispensáveis à discussão sobre a democracia diz respeito à cidadania.

Maria Victoria de Mesquita Benevides, em artigo publicado pela revista Lua Nova intitulado "Cidadania e Democracia", tratou sobre a noção de cidadania e mais duas questões correlatas: "o aperfeiçoamento dos direitos políticos do cidadão pela implementação de mecanismos de democracia direta [...]; e a educação política do povo, como elemento indispensável [...] da democracia e cidadania" (BENEVIDES, 1994, p.5).

Benevides nos lembra que a ideia moderna de cidadania está fundada "nas lutas e imaginários da Revolução Francesa", sem negar também a contribuição de suas ambiguidades: "o que significa ser cidadão? Até que ponto cidadania se confunde com democracia? Como se identificam - ou não - os direitos do homem e os direitos do cidadão" (BENEVIDES, 1994, p. 6).

Para a autora tanto a perspectiva progressista quanto a perspectiva conservadora carregam certa ambiguidade.

Para a esquerda, muitas vezes cidadania é apenas aparência de democracia, pois discrimina cidadãos de primeira, segunda, terceira ou nenhuma classe, acabando por reforçar a desigualdade [...]. Para os setores da "direita", a cidadania - por implicar a ideia de igualdade, mesmo que apenas igualdade jurídica - torna-se indesejável e até ameaçadora. As elites dependem, para a manutenção de seus privilégios [...], do reconhecimento explícito da hierarquia entre os superiores e inferiores. Consideram a desigualdade legítima e "os de baixo" são as classes perigosas. (BENEVIDES, 1994, p. 6-7)

Roberto DaMatta ilustra uma questão importante sobre a ambiguidade da cidadania no caso brasileiro.

O cidadão no caso brasileiro é o sujeito por excelência das leis impessoais e universais, bem como do poder brutal da polícia, que servem sistematicamente para diferenciá-lo e explorá-lo impiedosamente, tornando-o um igual para baixo, numa nítida perversão do ideário político liberal, conforme tenho procurado estudar no meu trabalho. (DAMATTA, 1991, p. 79, grifo do autor) 
O autor afirma que, por vezes, essa cidadania se apresenta como nivelador para baixo, demonstrando que em situações concretas o "ser cidadão" significa que o indivíduo está sob as rédeas das leis, em situação pejorativa, em oposição ao indivíduo que, por condição relacional, não segue as regras a que todos estão sujeitos. Essa situação pode ser enxergada no clientelismo político, na oferta de algum benefício em troca de apoio político, ou na relação direta do Estado com os cidadãos, em que o acesso a certos benefícios é "adiantado" por dada relação com um servidor público.

DaMatta (1991) demonstra que, além das distinções e variações que ocorrem sobre o conceito de cidadania ao longo do tempo em um mesmo período histórico, a concepção de cidadania, fundada em uma mesma matriz ideal, assume significados diferentes.

Retomando o pensamento de Bobbio (2009), este declara haver seis promessas não cumpridas pela democracia, entre elas a educação para a cidadania. Durante os séculos XIX e $\mathrm{XX}$, a cidadania ativa sempre esteve presente no discurso como elemento de efetivação da cidadania. Contudo, o autor considera que não teve sucesso a premissa de que o processo de educação para a cidadania se efetivaria durante o próprio exercício da democracia. Para ele, nas democracias mais consolidadas, são crescentes os processos de apatia política e de voto clientelar, realizado pela troca de apoio político por favores pessoais.

Bobbio (2009, p. 46) ainda questiona se as "promessas da democracia" poderiam ser cumpridas. Afirma que não, em razão da complexidade da sociedade moderna, visto que "o projeto político democrático foi idealizado para uma sociedade muito menos complexa que a de hoje" e as transformações da sociedade civil geraram alguns obstáculos, dos quais destaca três: 1) Oposição entre tecnocracia e democracia. À medida que a sociedade complexificou sua economia, surgem necessidades técnicas e, em consequência, uma crescente necessidade de especialistas, o que vai de encontro ao pressuposto de que na democracia todos podem decidir; 2) Crescimento do aparato burocrático. Embora, na história, o estado democrático e o burocrático estejam ligados, para o primeiro, o poder vai da base para o vértice e, no segundo, do vértice para a base; 3) Baixo "rendimento" do estado democrático, pois à medida que o estado democrático garante as liberdades civis (liberdade de imprensa, de associação e de reunião), a possibilidade da sociedade civil gerar demandas é, e inevitavelmente será, em decorrência de processos decisórios, superior à condição do Estado de atendê-las.

Não há dúvida de que a complexidade encontrada na sociedade atual é um desafio a ser vencido. Contudo, os obstáculos elencados pelo autor passam a impressão de uma dinâmica crescente e por assim dizer um efeito motriz que nos distancia cada vez mais do ideal da 
democracia. Então, o que pensar, ou em que se apoiar para afastar essa fatalidade? Bobbio (2009) responde que, apesar dos obstáculos, estes não levaram as democracias a regimes autoritários.

Benevides concorda com a ideia de que o exercício da cidadania se aprende pela prática. Mas observa que o próprio processo eleitoral (no Brasil) é um obstáculo à cidadania, na medida em que seus vícios e distorções de representatividade, o fisiologismo, clientelismo, coronelismo, abuso de poder econômico, entre outros, são entraves para a participação popular e reforço da cultura da apatia política. Assim, a autora defende "uma complementaridade entre a representação e a participação direta, sugerindo em decorrência, a expressão “democracia semidireta” (BENEVIDES, 1994, p.10).

Embora Benevides, quando se refere à democracia semidireta, considere a ampliação da participação do povo no processo decisório, por meio dos canais institucionais, "a eleição, a votação (referendo e plebiscito) e a apresentação de projetos de lei ou de políticas públicas (iniciativas populares)" (1994, p. 10), observando a preocupação com a ampliação da participação, não nega, de forma alguma, transpor esse pensamento para as instituições que materializam a presença do Estado na vida dos cidadãos. Então, quanto maior forem os espaços e formas que permitam aos cidadãos interferirem nos rumos da política e na organização da sociedade, mais se avança no processo de democratização.

Partindo da concordância com os autores, reflete-se: em que as ideias apresentadas têm a contribuir para a análise da questão da gestão democrática da escola? Primeiramente, a gestão democrática das escolas significa ampliação de um espaço para a participação dos cidadãos, a qual intensifica sua importância, na medida em que a escola pode se configurar como instituição que exerce funções contraditórias, isto é, como espaço que contribui para a reprodução e/ou a transformação social.

À gestão democrática da escola também interessa as três condições mínimas, defendidas por Bobbio (2009) para a definição de democracia. Assumir a necessidade de que a escola deve exercer sua função, de forma a contribuir para a transformação social, ampliar o número de participantes da vida dessa instituição e definir seus objetivos e ações de modo coletivo e democrático, é condição importante para promover a discussão e despertar a consciência para tal função.

Evidentemente, o envolvimento de alunos, pais, profissionais da educação e setores organizados da sociedade civil, na decisão dos rumos da escola, exige regras e procedimentos. 
Somente assim poder-se-á possibilitar que as ações das escolas reflitam os anseios da comunidade escolar.

A efetivação de reais condições para decidir completa as duas condições anteriores. Talvez aqui esteja um dos grandes problemas da efetivação da gestão democrática da escola. Um primeiro elemento está relacionado às diferenças entre os setores para decidir, as quais estão associadas ao acesso às informações, ao nível de organização e ao domínio das normas, procedimentos e burocracia.

Compreender a democracia como processo também se aplica à gestão democrática da escola. Mesmo sendo possível estabelecer ações que criem condições para que a comunidade escolar decida, esta só aprenderá a decidir decidindo, ou seja, proporcionando espaços para a participação de alunos, pais, e profissionais da educação (estes com mais facilidade, em razão de sua história de lutas e organização, além do contato constante com a burocracia) na tomada de decisão. A participação é também condição mínima para que se construam reais condições de decidir, as quais, portanto, não devem preceder à participação. Logo, a gestão democrática da escola pressupõe espaços de decisão.

A seguir, verifica-se como o princípio da gestão democrática se insere no contexto brasileiro e suas questões adjacentes.

\subsection{O princípio da gestão democrática da escola no Brasil}

A temática da democracia e sua relação com a educação não é recente no Brasil. Anísio Teixeira, em suas contribuições como intelectual e também como "homem de governo", tratou da questão da democratização da gestão, da descentralização dos sistemas de ensino e da autonomia na educação tanto no período da ditadura de Getúlio Vargas quanto no que antecede a elaboração da LDB de 1961, então como diretor do Instituto Nacional de Estudos e Pesquisas Educacionais (Inep) (MACHADO, 2004).

Segundo o próprio autor:

Encarado o assunto do ponto de vista mais consentâneo com o progresso e o desenvolvimento da educação, nas suas linhas fundamentais, não pode, hoje, recusar ou duvidar que o controle pelas forças sociais, e não somente pela Igreja ou pelo 
Estado, seja o mais favorável à livre e plena expansão das instituições educativas. (TEIXEIRA, 1997, p. 54).

Teixeira ressalta a estreita ligação e mútua dependência entre democracia e educação: a “democracia sem educação e educação sem liberdade são antinomias, em teorias, que desfecham, na prática, em fracassos inevitáveis” (1997, p. 57). O autor assinala que a aprovação da Constituição Federal de 1934 tem o sentido de dar autonomia ao governo da educação.

\footnotetext{
Os órgãos que a vão dirigir [a educação] são, hoje, órgãos constitucionais, que retiram a sua autoridade e sua competência da própria lei magna do país. Deve, por isso mesmo, trazer características que rasguem os sistemas escolares brasileiros novos rumos para seu progresso mais eficaz e mais seguro. São esses novos rumos que as novas leis devem concretizar, dando os primeiros passos para o desenvolvimento e desdobramento dos princípios e das instituições criadas pela Constituição. Ensaiar-se-á, por esse modo, no país, o governo autônomo da educação, confiando-se os seus destinos a corporações representativas da sociedade, sem eiva de partidarismo de qualquer espécie e capazes de conduzir com segurança e estabilidade o seu progresso e desenvolvimento. (TEIXEIRA, 1997, p. 57).
}

Embora Teixeira estivesse falando sobre a democratização dos sistemas de ensino, fica clara a preocupação de que a educação deve ter a definição de seus rumos compartilhada com a sociedade. Evidentemente, a discussão não trata do envolvimento direto dos membros da comunidade nas decisões das escolas, mas aponta para a necessidade de entender a educação como questão de política pública e não política de estado, ou melhor dizendo, de governo.

Quanto às propostas de envolver os estudantes, os pais e as famílias nas escolas, cabe destacar que são, também, de longa data na história do ensino público no Brasil. Contudo, Spósito (2000) destaca que as propostas traziam orientações extremamente conservadoras. A partir da década de 1920, as teses reformistas propõem que as escolas se abram para a comunidade, mas apenas o sistema de instrução elementar (ou antigo primário), pois se destinava à população de forma mais abrangente. Os setores populares da sociedade tiveram sua integração pautada por ações de ordem sanitária, higiênica e moral-cívica. Para a escola secundária não havia proposta de integração da comunidade, pois se acreditava que não havia a necessidade de interferência com esse tipo de ações, uma vez que tal etapa da educação estaria destinada a uma pequena parcela da população, à formação da elite brasileira.

Na década de 1970, período marcado pela opressão do regime militar às organizações populares, a participação da comunidade nas escolas é estabelecida de forma compulsória. A obrigatoriedade de criação de formas de participação é concretizada por meio das APMs. 
Spósito afirma que essa participação constituía uma "cidadania sob controle", e mais: "tais intenções foram, em geral, traduzidas, em um conjunto de práticas assistencialistas, sanitárias ou de caráter cívico, [...] privilegiando a tutela e a subordinação política e cultural dos setores desprivilegiados" (SPOSITO, 2000, p. 48).

Após o período de opressão e violência do governo militar e iniciado o processo de redemocratização do País, a década de 1980 é marcada pelo acúmulo de discussões e formulações a respeito das liberdades democráticas pelos movimentos sociais, na tentativa de combater o autoritarismo do Estado daquele último período. Assim, entre as bandeiras de reivindicações dos movimentos sociais, que discutiam ou julgavam importante a educação, estava presente a gestão democrática como forma de participação da população nas tomadas de decisão.

Após o processo de redemocratização, a participação dos estudantes, por meio dos grêmios estudantis, tem regulamentação aprovada antes da $\mathrm{CF} / 88$, por intermédio da Lei federal 7.398/1985, pelo então presidente José Sarney. Sucinta, a lei trata, em seu artigo $1^{\circ}$, da questão dos grêmios estudantis:

\footnotetext{
Art. $1^{\underline{0}}$ - Aos estudantes dos estabelecimentos de ensino de $1^{\underline{0}}$ e $2^{\underline{0}}$ graus fica assegurada a organização de estudantes como entidades autônomas representativas dos interesses dos estudantes secundaristas com finalidades educacionais, culturais, cívicas esportivas e sociais.

$\S 1^{\circ}$ - (VETADO).

$\S 2^{\underline{0}}$ - A organização, o funcionamento e as atividades dos Grêmios serão estabelecidos nos seus estatutos, aprovados em Assembleia Geral do corpo discente de cada estabelecimento de ensino convocada para este fim.

$\S 3^{\mathrm{o}}$ - A aprovação dos estatutos, e a escolha dos dirigentes e dos representantes do Grêmio Estudantil serão realizadas pelo voto direto e secreto de cada estudante observando-se no que couber, as normas da legislação eleitoral. (BRASIL, 1985).
}

Silva ressalta que a aprovação na lei se dá em momento de fortalecimento das organizações da sociedade civil e processo de redemocratização do País. A autora considera que:

O grêmio poderá ser uma importante referência de exercício e de conquista de direitos, de formação de sujeitos históricos autônomos e críticos, sensíveis à prática de ações democráticas e coletivas. Esse espaço poderá, pois, garantir que os alunos discutam, criem e fortaleçam múltiplas possibilidades de ação, tanto no interior da escola como na comunidade. (SILVA, 2008, p.88)

No mesmo período, o surgimento do Fórum Nacional de Entidades em Defesa da Escola Pública, ao final da década de 1980, por meio da Campanha Nacional pela Escola Pública e Gratuita é significativo. Entre suas bandeiras de reivindicação, estão a criação de 
um Sistema Nacional de Educação, a democratização da gestão educacional e a participação popular em conselhos. A forma de pressão realiza-se mediante manifestos, produzidos pelo fórum, direcionados aos parlamentares no processo constituinte (SILVA, 2008).

No decorrer do fortalecimento das lutas dos movimentos sociais pelas liberdades democráticas, a formulação da $\mathrm{CF} / 88$ traz, pela primeira vez, a gestão democrática como princípio da educação nacional. Contudo, a redação se restringe ao ensino público e não estabelece as diretrizes sob qual o princípio seria gerido. “Art. 206. O ensino será ministrado com base nos seguintes princípios: [...] VI - gestão democrática do ensino público, na forma da lei”. (BRASIL, 1988).

A formulação, presente na $\mathrm{CF} / 88$, é feita em meio aos conflitos entre os setores progressistas e conservadores. Camargo descreve que a formulação dos setores mais democráticos e progressistas se pautava pela garantia de:

[...] uma vivência democrática na escola, ao se pretender formar cidadãos para uma sociedade participativa e igualitária, e formularam a definição no texto constitucional da seguinte maneira "gestão democrática do ensino, com participação de docentes, alunos, funcionários e comunidade”. (CAMARGO, 1997, p. 101-102)

Os setores conservadores e o "Centrão" atacaram fortemente tal formulação. O anteprojeto encaminhado para plenário trazia o conceito de gestão democrática do ensino, contudo, por meio de emenda coletiva dos setores conservadores, ao texto foi acrescido o termo "público", resultando em "gestão democrática do ensino público", o que eximiu o ensino privado de respeitar tal princípio (CAMARGO, 1997).

As movimentações sociais que tiveram forte expressão no processo constituinte na década de 1980, reivindicando mais participação, para Cury (2000) traziam três vertentes: distinção entre público e privado, característica dos Estados nacionais modernos, presente no art. 37 da CF/88; princípio da gestão democrática para educação pública; e concepção de federação em regime de colaboração ${ }^{5}$.

Cury revela que os anseios pela gestão democrática são mais abrangentes que a garantia de transparência, impessoalidade e moralidade, presentes no art. 37 da CF/88:

Ela expressa tanto a vontade de participação que tem se revelado lá onde a sociedade civil conseguiu se organizar autonomamente, quanto o empenho por reverter a tradição que confunde os espaços públicos com os privados.

\footnotetext{
5 Trata-se de uma questão complexa, mas por fugir às necessidades do trabalho não será melhor explorada. Para aprofundamento, ver: Cruz (2009); Arretche (2000); entre outros.
} 
A gestão democrática é também a presença no processo e no produto de políticas de governo. Os cidadãos querem mais do que ser executores de políticas, querem ser ouvidos e ter presença nos momentos de elaboração. (CURY, 2000, p. 55)

As diretrizes de implantação do princípio da gestão democrática do ensino público são enviadas para a LDB, promulgada somente oito anos depois. Assim, fica a cabo dos sistemas de ensino implantarem a gestão democrática segundo seus entendimentos. (ADRIÃO; CAMARGO, 2002; SILVA, 2008)

A presença do princípio da gestão democrática na $\mathrm{CF} / 88$, embora tenha colaborado com a disseminação de algumas práticas democráticas já existentes na década de 1980 (como os conselhos escolares, eleições para diretores e incentivo aos grêmios estudantis, experimentadas em algumas redes), não garante maior participação efetiva da população na tomada de decisão das políticas das redes de ensino (ADRIÃO; CAMARGO, 2002).

Na elaboração da LDB, a conjuntura expressava condições desfavoráveis na correlação de forças para os setores progressistas, resultando em uma redação ambígua em inúmeras matérias, expressando influência dos setores conservadores e lobistas das instituições educacionais privadas.

Silva (2008) descreve que o Fórum Nacional em Defesa da Escola Pública declara que o projeto do senador Cid Sabóia (PMDB) estava de acordo com os princípios que defendiam e criticavam efusivamente o projeto substitutivo apresentado pelo senador Darcy Ribeiro (PDT) em pactuação com o MEC, considerando-o um retrocesso nas discussões da LDB.

No que diz respeito à gestão democrática, o texto aprovado da LDB/96 (Lei 9.394/1996), em seu art. $3^{\circ}$, praticamente repete a formulação da CF/88, acrescida da sujeição

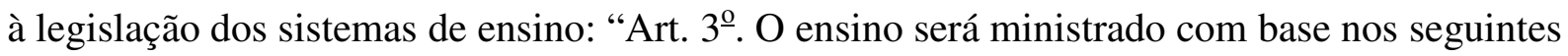
princípios: [...] VIII - gestão democrática do ensino público, na forma desta Lei e da legislação dos sistemas de ensino.” (BRASIL, 1996).

Há também menção no art. 14, que reafirma a transferência aos sistemas de legislarem sobre a questão. Os princípios são genéricos, não determinam sobre o que podem decidir, a forma, e nem declara se os conselhos escolares possuem caráter deliberativo.

Art. 14. Os sistemas de ensino definirão as normas da gestão democrática do ensino público na educação básica, de acordo com as suas peculiaridades e conforme os seguintes princípios:

I - participação dos profissionais da educação na elaboração do projeto pedagógico da escola;

II - participação das comunidades escolar e local em conselhos escolares ou equivalentes. (BRASIL, 1996). 
Ainda sobre gestão democrática, é preciso lembrar da eleição como forma de escolha de diretores de escola, questão não menos importante que polêmica, e que ficou fora da LDB/96. Paro (2003) destaca que democratização social significa distribuição do poder concentrado no Estado, em especial para as instâncias que mantêm interface direta entre este e os cidadãos. É inevitável que a tradição política brasileira, bem como outros Estados modernos liberais, tendem a relutar contra essa disseminação do poder pelas instituições estatais, ainda mais propiciar aos usuários dos serviços públicos a participação nas tomadas de decisão, no caso a escolha dos dirigentes.

O autor também discorre sobre os diversos argumentos contrários à eleição, muitos dos quais impõem condicionantes anteriores ao processo de escolha por eleição, por exemplo, a necessidade de primeiro democratizar a sociedade. Essas ideias espelham os argumentos mais conservadores que se opõem à participação popular e pregam que a população "não sabe votar". Claro que se para o argumento de negação da soberania popular se diz que "votar se aprende votando", o mesmo pode ser dito para as eleições de dirigentes das escolas. Outro argumento contrário diz que a eleição pode gerar dentro da escola a "instabilidade". Justamente esse é um argumento favorável à eleição de diretores, pois a temida instabilidade pode significar explicitação dos conflitos e das contradições presentes no interior das escolas e de nossa sociedade, e só podemos dar respostas aos problemas, à medida que os reconhecemos.

Como já foi apresentado, embora a LDB/96 não delimite o princípio da gestão democrática, apresenta mais um elemento a ser construído, a autonomia escolar.

Art. 15. Os sistemas de ensino assegurarão às unidades escolares públicas de educação básica que os integram progressivos graus de autonomia pedagógica e administrativa e de gestão financeira, observadas as normas gerais de direito financeiro público. (BRASIL, 1996)

Paro (2002) alerta para as ambiguidades presentes no texto da LDB, que representam armadilhas para a implantação do princípio da gestão democrática. O autor apresenta uma preocupação em a autonomia administrativa ser implementada somente no aspecto da desconcentração de tarefas e, no que tange a gestão financeira, as escolas sejam responsáveis pelo seu próprio financiamento.

Compreendendo as complexidades do processo histórico que alicerçaram as políticas para a educação no Brasil, é importante discutir qual significado a gestão democrática tem na disputa dos rumos da educação. Segundo Ferreira: 
A análise das possibilidades da administração da educação como prática educacional destinada não à manutenção, mas à construção coletiva e organizacional da instituição educativa vinculada ao projeto político pedagógico da escola, tendo como referencial o contexto global e as teorias contemporâneas que valorizam a potencialidade e a capacidade participativa do ser humano, ressignificam o valor dessa prática, conferindo à gestão da educação uma práxis que tenderá a superar nas organizações educacionais, as fraquezas institucionais e humanas que resultam em exclusão, desigualdades e injustiça. (FERREIRA, 2000, p. 297)

Embora muito se tenha acumulado sobre a concepção de gestão democrática e algumas experiências já permeiem as práticas escolares, trata-se de um processo que envolve a construção de uma cultura diferente da historicamente construída em nosso País.

Todavia é realidade, ainda, que a compreensão teórico-prática da gestão democrática da educação ainda está se fazendo, no próprio processo de construção do projeto político-pedagógico e da autonomia da escola, que embora já seja uma convicção e uma prática em desenvolvimento, ainda não é uma realidade da vida social e profissional. (FERREIRA, 2000, p. 297)

Para Luz (2000), o princípio da gestão democrática na educação abarca pelo menos três elementos: administração descentralizada com participação dos diferentes segmentos sociais na política educacional e na gestão da escola; propostas pedagógicas e projeto político pedagógico devem ser discutidos por todos, permitindo a interferência dos segmentos sociais no processo; e participação e fiscalização dos diferentes segmentos sociais sobre o financiamento da educação.

Pode-se ao menos afirmar que, na medida em que esses elementos tornam-se parte da cultura escolar, o processo de construção de uma cidadania participativa avança. Para Melo (2000), existem seis indicadores fundamentais ao processo: a autonomia escolar; a descentralização do poder; a representatividade social dos Conselhos de Escola; o controle social da gestão educacional; a escolha dos dirigentes escolares por processos de eleição; e a inclusão de todos os segmentos da comunidade escolar.

Ao questionar a difusão do papel da gestão escolar como racionalizadora dos recursos financeiros, Aguiar expõe três aspectos que são reservados ao papel da gestão escolar:

1. A organização da sociedade civil. A escola, na medida em que envolve a comunidade na gestão, [...] contribui com a própria organização da sociedade civil. Isso significa dizer que o efeito da gestão participativa da escola pode repercutir na organização da sociedade fora da escola. [...] 2. A formação do sujeito social. [...] A gestão da escola participa na formação do sujeito social como membro decisório do cotidiano administrativo da escola ou como ator aluno. [...] 3. O fortalecimento do local em contraposição ao global. Os paradigmas da sociedade em rede demonstram o efeito dialético da globalização no fortalecimento das identidades locais. [...] A 
escola, na medida em que participa da formação do sujeito social, organiza, fortalece e constrói a identidade social local. ( AGUIAR, 2000, p. 237-238)

Como concepção norteadora das análises deste trabalho, entende-se para efetivação do princípio da gestão democrática: que se trata de um processo e não de um estado; que envolve a inclusão do maior número de participantes possível; que os participantes tenham condições reais para decidir; que a discussão e a elaboração do projeto político pedagógico da escola propiciem a participação de toda a comunidade escolar; que haja participação nos processos de decisão e fiscalização dos diferentes segmentos da comunidade escolar sobre o financiamento da educação; que a escolha dos dirigentes escolares seja realizada por eleição.

Portanto, a tarefa de construir a gestão democrática inclui vários fatores. Contudo, pensar a implementação da gestão democrática sem a garantia da autonomia da gestão financeira seria impossível, pois limitaria as ações das unidades escolares. Mas, como problematizado anteriormente, isso não significa responsabilizar as escolas pela captação de recursos para sua manutenção, mas garantir as condições mínimas para fazer valer a autonomia das escolas e implementação de seu projeto político pedagógico. Desse modo, os mecanismos de descentralização financeira são extremamente relevantes na discussão da questão da gestão democrática.

\section{POLÍTICAS DE DESCENTRALIZAÇÃo}

Neste capítulo, pretende-se esclarecer conceitualmente o termo da descentralização, examinando suas possíveis formas e manifestações, como esforço teórico para substanciar a análise do PTRF.

Para tanto, será feito um exame das formas com que a descentralização tem ocorrido na educação. No bojo da discussão, será observada a questão da descentralização de recursos financeiros e suas possibilidades no Brasil. 


\title{
2.1. O conceito de descentralização
}

Preliminarmente, para delimitar o conceito de descentralização, é necessário compreender que não se trata de instituição única e definida em si mesma. Roversi destaca que:

\footnotetext{
A centralização e a Descentralização (sic) em geral (e também a centralização e a Descentralização (sic) administrativa) não são instituições jurídicas únicas, mas fórmulas contendo princípios e tendências, modos de ser de um aparelho político ou administrativo, são, portanto, diretivas de organização no sentido mais lato e não conceitos imediatamente operativos. (ROVERSI, 1992, p. 329)
}

Outra premissa elementar a ser considerada, derivada da anterior, é que a descentralização (ou centralização) não pode ser capturada a priori por determinado marco ideológico, ou seja, não traz em si uma identificação com determinada ideologia. Para Casassus:

\begin{abstract}
A descentralização não é um fim em si mesma: a descentralização (ou centralização) é uma política para alcançar certos fins. Em si, ela não é boa nem má, não é progressista ou conservadora. É uma política que pode ser boa ou má, progressista ou conservadora, dependendo de quem a utilize e se contribui ou não para resolver os problemas. (CASASSUS, 1995, p. 39)
\end{abstract}

A descentralização, embora possa parecer categoria dicotômica à centralização, só pode ser entendida em sua totalidade no plano da ideia. Por mais que haja esforços para uma centralização total, a complexidade da sociedade moderna a torna impossível. O mesmo podese atribuir à descentralização, ao ponto de que pensar uma descentralização absoluta implica a própria negação da noção de Estado (ROVERSI, 1992).

Ao conceito de descentralização podem ser feitas algumas distinções, às vezes de caráter específico das ciências jurídicas, outras, de uso mais comum. A descentralização administrativa e a política, por exemplo, além de suas naturezas diferentes, observa-se que a primeira está relacionada à execução das diretrizes do Estado, à forma organizativa e derivada dos poderes administrativos do aparelho estatal, enquanto que a segunda relaciona-se à elaboração de decisão política do Estado e ao direito autônomo que incide na garantia de autonomia e poderes a espaços não centralizados, assim podendo se opor à instituição central (ROVERSI, 1992). 
Outra distinção é a desconcentração, ou descentralização hierárquica, que, para Roversi (1992), consiste na descentralização para instituições locais sem que isso comprometa a hierarquia, ou seja, a instituição central ainda resguarda o poder de se sobrepor às decisões periféricas e impor a sua decisão. Assim, as medidas de desconcentração apontam mais para desafogar a administração pública central do que a efetiva autonomia das instituições locais ou periféricas.

Para Cretella Junior, no que diz respeito ao direito administrativo, desconcentração é “a irradiação de poderes da mão de um para a de muitos", e descentralização, "a transferência de atribuições em maior ou menor número dos órgãos centrais para os órgãos locais ou para pessoas físicas ou jurídicas" (CRETELLA JUNIOR, 1973, p. 89). O autor afirma que não há confusão entre ambos os termos, pois a descentralização "é vocabulário eminentemente técnico".

Para a abordagem da temática da descentralização de recursos financeiros, é interessante observar o que Cretella Junior (1973) chama de "descentralização por colaboração", tipologia que se refere à transferência de atribuições do Estado para pessoas físicas ou pessoas jurídicas de direito público ou privado. Isso ocorre por meio de delegação, de concessão ou por autarquias.

Casassus (1995) considera que as políticas ditas de descentralização são, na prática, políticas de desconcentração e que é comum enxergá-las como processo contínuo. A desconcentração seria uma primeira fase, antecedente à descentralização. Embora possa ocorrer, o autor acredita que esse pensamento leva à nebulização da natureza dos processos. Assim, considera mais proveitoso analisar as políticas de descentralização a partir da perspectiva territorial.

\footnotetext{
Nesse aspecto, [...] a desconcentração é uma perspectiva e uma política que reflete os interesses do poder central, com seu desejo de levar as decisões para mais perto do lugar em que ocorre o ato educacional. Por esse prisma, a desconcentração é uma política que reflete a lógica do poder central. Do ponto de vista do sentido, a desconcentração poderia ser desenhada como uma flecha que vai de cima para baixo. (CASASSUS, 1995, p. 40)
}

Rivas (1991), em seu estudo Política de descentralización en la educación básica y media en América Latina: Estado del Arte, adota a seguinte definição de desconcentração:

Por desconcentração se entende a administração do sistema em que o Estado central delega determinadas funções a entidades regionais ou locais que dependem diretamente dos ministérios centrais, mas mantendo concentrado em seu poder a tomada de decisão sobre todos os aspectos antes mencionados [financiamento, 
contratação de pessoal, elaboração de planos de gestão e currículos, supervisão etc.] e a faculdade para outorgar, alterar ou retirar atribuições dos funcionários destes departamentos ou simplesmente removê-los. A delegação de funções operativas se faz a organismos que não são autônomos, mas que estão sob a dependência direta do poder central. (RIVAS, 1991, p. 20, tradução nossa ${ }^{6}$ ).

Outra dimensão que podemos encontrar de descentralização é a fiscal, relacionada à distribuição das receitas e despesas entre o governo central, os governos regionais e os locais. Há uma crescente participação dos governos locais nos gastos públicos a partir dos finais dos anos 70. Contudo, conforme estudo de Rodden (2005), isso não pode ser generalizado. Posteriormente aos anos 90, os governos centrais passam a retomar o controle dos gastos públicos, sendo que a descentralização fiscal permanece em países como a Espanha e parte da América Latina.

É importante diferenciar a descentralização política da fiscal, pois elas não têm implicação direta entre si, embora ambas se confundam no processo. Podem-se encontrar situações em que os governos locais têm autonomia para arrecadar, mas o governo central ainda possui o poder de regular a arrecadação de "recursos próprios", determinando alíquotas ou bases tributárias. Assim, resta aos governos locais apenas o papel de arrecadar segundo as determinações do governo central (RODDEN, 2005).

Roversi (1992) traz também distinções tipológicas da descentralização, como a autárquica, que consiste na existência de instituições autônomas dentro da estrutura administrativa estatal, e a de serviços, fundamentada na divisão em entidades com personalidade jurídica autônoma por setor de atividades homogêneas. Tais tipos de descentralização estão ligados à ideia de descentralização administrativa, mas não em perspectiva vertical, mas sim horizontal das funções.

Para esta pesquisa se adotará como definição do termo descentralização a sua forma mais genérica de distribuição de atividades/funções/atribuições centralizadas para o âmbito local. Em relação às diferenciações e tipologias apresentadas anteriormente, serão tomadas como referências (ou categorias) para análise do processo. Assim, em vez de se tentar classificar ou diferenciar o tipo de descentralização, será observado na política do PTRF seus aspectos políticos, administrativos e jurídicos.

\footnotetext{
${ }^{6}$ No original: "Por desconcentración se entiende la administración del sistema en que el Estado central delega determinadas funciones a entidades regionales o locales que dependen directamente de los ministerios centrales, pero manteniendo concentrado em su poder la toma de decisiones sobre todos los aspectos antes señalados y la facultad para otorgar, modificar o retirar atribuciones a los funcionários de estas reparticiones o simplemente removerlos. La delegación de funciones operativas se hace a organismos que no son autónomos sino que están bajo la dependência directa del poder central." (RIVAS, 1991, p. 20).
} 


\title{
2.2. Autonomia escolar
}

Em oposição à concepção taylorista, ou de administração científica, somado ao modo de produção fordista, que se fundamenta na divisão entre a concepção e a execução na produção, surgem os movimentos autônomos e/ou pela ampliação de participação de trabalhadores nas empresas. Inicialmente como negociações coletivas entre patrões e trabalhadores, mediadas por diretorias de sindicatos ou associações. Nesse contexto de conflito, outras formas aparecem, como a cogestão, em que os trabalhadores passam a influir nas tomadas de decisões no processo de produção, e a autogestão (a partir do final do século XIX), que consiste na autoadministração pelos trabalhadores, estes detendo o poder de decidir. A primeira experiência de gestão de empresa, intitulada como autogestão, ocorre na Iugoslávia, a partir de 1951. Anos mais tarde, passa a ocupar questões na academia e no sindicato (MARTINS, 2002).

Martins (2002) localiza em outras línguas termos equivalentes, como: democracia industrial, autogoverno, autodeterminação, cogestão, participação e autonomia. No entanto, ressalta que é difícil demarcar os limites conceituais entre movimentos autogestionários, participativos e autônomos.

\begin{abstract}
Torna-se complexo estabelecer um rígido limite conceitual entre termos equivalentes, pois, via de regra, a reivindicação pela autonomia que pontuou a Comuna de Paris, a Revolução Espanhola entre 1936 e 1939, o socialismo no caminho próprio da Iugoslávia e o movimento sindical na Polônia nos anos 1970 expressava os ideais de movimentos exemplares de trabalhadores que reivindicavam uma mudança valorativa na representação política, adquirindo, como forma de participação institucional, a dinâmica autogestionária. Invariavelmente, todos esses movimentos têm sido movidos pela mesma substância política e social, pois, historicamente, reivindicam a ampliação das bases que sustentam a democracia no que tange à representação política e, consequentemente, à distribuição de poder, bem como uma organização coletiva baseada na livre associação de trabalhadores ou produtores. (MARTINS, 2002, p. 18, grifos do autor)
\end{abstract}

O conceito de autonomia na educação é objeto de debate de longa data. A partir das contribuições dos educadores que formularam o que passou a se chamar de movimento Escola Nova, questionando-se a concepção da escola tradicional sobre a relação entre professor e aluno, pondo em xeque a hierarquização dessa relação.

A autora aponta uma tendência internacional, que pode ser verificada pelas orientações dos organismos multilaterais e nos programas de governo, por formas mais livres de organização dos sistemas educativos, realizadas por meio da descentralização e autonomia 
escolar. Contudo, nos alerta que "essa perspectiva [...] vem construindo uma noção de autonomia esvaziada de seu significado original." (MARTINS, 2002, p. 48).

Também considera que o termo autogestão não está mais substantivamente presente nas diretrizes das políticas educacionais, podendo-se até dizer que sumiram do horizonte destas.

No debate da área educacional, o conceito de autonomia vem sofrendo um processo de sacralização e, ao que tudo indica, encontra-se reduzido à redefinição de procedimentos administrativos e financeiros da rede de escolas, com significativa ampliação de encargos e responsabilidades para elas. (MARTINS, 2002, p. 48)

Barroso (1996) vai chamar as políticas de descentralização, no sentido de cima para baixo das transferências de poderes, obrigações e competências para os níveis locais, como autonomia decretada. Afirma, porém, que não há como se decretar uma autonomia, pois o que ocorre são apenas normas e regras formais para regularem as competências, obrigações e a distribuição dos poderes entre os níveis de administração, e "essas normas podem favorecer ou dificultar a 'autonomia da escola' mas são, só por si [...], incapazes de a criar ou a destruir.” (BARROSO, 1996, p. 186)

$\mathrm{O}$ autor considera também que, independentemente da autonomia decretada, as escolas no seu cotidiano "desenvolvem (e sempre desenvolveram) formas autônomas de tomada de decisão, em diferentes domínios, que consubstanciam aquilo que pode ser designado por autonomia construída.” (BARROSO, 1996, p. 185)

\subsection{A descentralização como política educacional}

A história da educação na América Latina está imbricada ao processo de formação do Estado nação independente. $\mathrm{O}$ processo de construção da identidade de nação apoia-se na educação para auxiliar na execução dessa tarefa. Com tal intenção é que na maioria dos países da América Latina surgem os sistemas nacionais de educação pública de forma centralizada. Essa centralização se mantém até o final da década de 1970 (CASASSUS, 1995; RIVAS, 1991). 
Após a crise econômica de 1930 e a Segunda Guerra Mundial, o Estado passa a assumir papel ativo no desenvolvimento econômico, por base no keynesianismo, na substituição das importações, na industrialização e na planificação. Contudo, nas décadas seguintes, o Estado planificador sofre duras críticas. O aparelho burocrático é identificado como ineficiente e oneroso, e os problemas de desemprego aumentam à medida que se torna cada vez mais difícil manter as altas taxas de crescimento (RIVAS, 1991).

$\mathrm{Na}$ época, diferentemente dos EUA e Canadá, também afetados pelas crises, os países da América Latina têm seus Estados modernos estruturados sobre uma economia basicamente agrária e, por isso, a maior parte da população estava na área rural, havia alta estratificação social e um embrionário processo de industrialização. Outro elemento que agravava a situação desses países está relacionado ao fato de serem Estados capitalistas dependentes, o que é característico por grande parte do poder econômico ser exógeno, assim dificultando a construção do Estado soberano (RIVAS, 1991).

Após o primeiro momento de criação dos sistemas de ensino centralizados, alguns dos países da América Latina passam por novo momento de reorganização dos sistemas de ensino. Fundado na leitura de que o Estado é o epicentro da crise, e não o capital, muitos países sofrem processo de reforma do Estado.

É nesse contexto, associado às declarações ${ }^{7}$ dos ministros da educação de que os sistemas educacionais da região estavam esgotados, que a forma de gestão dos sistemas deveria ser mudada e a ideia de imbricamento da qualidade com descentralização, que são propostas as reformas educacionais nos anos 80 e 90 (RIVAS, 1991), as quais tiveram caráter uniformizador e padronizador. Os estudos analisados, entretanto, demonstram que, mesmo sob as mesmas diretrizes, as mudanças ocorrem de formas diferenciadas, o que expressa a complexidade do contexto histórico, político e social ao qual cada País estava inserido.

O Brasil, a exceção da maioria dos países da América Latina, desde o período do império tem seu sistema de ensino descentralizado. Contudo, isso não significou que o país não passasse pelas reformas educacionais sob as mesmas diretrizes que os seus países vizinhos.

Na definição do conceito de descentralização, observa-se que não guarda em si relação direta com determinada orientação ideológica, mas é concretizada em determinados valores e contextos.

\footnotetext{
${ }^{7}$ No Promedlac IV (sigla atribuída à Reunião do Comitê Regional Intergovernamental do Projeto Principal de Educação, América Latina e Caribe), em 1992, na cidade de Quito.
} 
O esgarçamento dos sistemas educativos centralizados para responder a questões surgidas com a expansão dos sistemas, ampliação do atendimento, a discussão sobre as funções do Estado, bem como a questão da qualidade levam a depositar as atenções na ideia da descentralização educacional na América Latina.

Casassus (1995) aponta cinco "promessas" das políticas de descentralização: maior possibilidade de participação, consequentemente maior democratização; maior eficiência derivada da ampliação do controle social; mais recursos com a participação da sociedade civil, atraindo recursos do setor privado; desburocratização e aumento da eficiência dos recursos por conta do maior controle social; e maior qualidade na educação pela aproximação da comunidade e atenção às necessidades locais.

Rivas (1991) considera que se pode encontrar algumas lógicas que são usadas como justificativa para tal política: a) racionalidade neoliberal quando as propostas de descentralização seguem uma necessidade de reduzir os gastos públicos e privatizar o máximo de escolas; b) racionalidade geopolítica, quando fundamentada na ideia de ocupação do território e desenvolvimento local, propiciando integração das regiões separadas do conjunto do país; c) racionalidade da eficiência administrativa (também presente na anterior), que consiste na desconcentração para garantir processos administrativos mais eficientes sem ceder o poder de orientar as ações; d) lógica democrática participativa, que deriva da ideia de transferir para instâncias locais maior poder, recursos e autonomia para decidir.

Dessa forma, as diferentes modalidades que adquirem os processos de
descentralização respondem a diferentes lógicas com as quais se enfrentam as crises
do Estado, lógicas que, por sua vez, resultam da luta e relativa hegemonia de
distintos grupos de interesses e gestão no interior de seus aparatos. Não é raro,
então, que seja distinta a maneira de conceitualizar os problemas que levam aos
processos de descentralização, nas dimensões que os enfatizam, os papeis do Estado
que a ele se atribui e, mesmo, que seja diferente até o próprio conceito de
descentralização. (RIVAS, 1991, p. 16, tradução nossa ${ }^{8}$ )

As lógicas podem ser encontradas nos objetivos oficiais declarados. Os processos de descentralização educacional, conforme estudo de Rivas (1991), traziam três objetivos: melhorar a eficiência e modernizar a administração dos sistemas educacionais; melhorar a gestão administrativa, incluindo mais atores sociais aos processos de decisão; e aumentar a

\footnotetext{
${ }^{8}$ No original: "De esta manera, las diferentes modalidades que adquiren los procesos de descentralización responden a diferentes lógicas com que se enfreta la crisis del Estado, lógicas que a su vez resultam de la lucha y relativa hegemonia de distintos grupos de presión y gestión al interior de sus aparatos. No es raro, entonces, que sea distinta la manera de conceptualizar los problemas que collevam los procesos de descentralización, lãs dimensiones que se enfatizan de ellos, los papeles que al Estado se Le asignan e, incluso, que sea diferente hasta el próprio concepto de descentralización”.
} 
efetividade do sistema. Cada objetivo responde a orientações ou racionalidades diferentes, mas não excludentes entre si, e podem estar presentes em um mesmo discurso.

Em relação ao objetivo de diminuir a burocratização, os efeitos podem ser justamente o contrário. Não foram raros os casos em que a descentralização significou uma reprodução das instituições burocráticas antes centralizadas, havendo também aumento de pessoal para responder às necessidades das novas administrações.

Quanto à eficiência, esta não tem relação direta ou causal com a estrutura. Podem-se encontrar níveis aceitáveis em relação à qualidade, aos recursos ou à burocracia em sistemas tanto centralizados quanto descentralizados. Casassus (1995) cita como exemplo de sistemas descentralizados, os da Alemanha, do Reino Unido e dos EUA, e de centralizados, os da França, da Coreia do Sul e do Japão.

$\mathrm{Na}$ América Latina, podem-se encontrar três modalidades de descentralização educacional: a nuclearização, a regionalização e a municipalização. A primeira parte da ideia de agrupar escolas, que muitas vezes possuem um único professor, por regiões determinadas. Essa área, ou região, pode ser determinada por critérios demográficos, topográficos, socioeconômicos etc. Muitas dessas experiências adotaram uma escola como coordenadora do núcleo educacional. Algumas com essas características foram realizadas no Peru, na Argentina, na Costa Rica, no Equador, na Nicarágua, no Panamá, entre outros países. Opostamente à nuclearização, a regionalização não parte de um movimento das bases sociais para o governo central, mas sim como instrumento técnico-burocrático de planejamento nacional, envolvendo todas as instituições do Estado, distribuindo responsabilidades dos órgãos centrais, sem deixar de ter o controle, para instâncias regionais, caracterizando-se mais como movimento de desconcentração do que de descentralização. A municipalização assume caráter mais descentralizador, pois, diferentemente da regionalização, a educação municipalizada possui maior autonomia em relação ao governo central. Dois fortes casos, distintos entre si, são o do Brasil e do Chile (RIVAS, 1991; CASASSUS, 1995).

Apoiados na justificativa de modernizar as estruturas arcaicas e ineficientes do Estado, foram propostos e incentivados, por meio das organizações internacionais com o Fundo Monetário Internacional (FMI) e o Banco Mundial (BM), processos de reformas educacionais.

Os documentos do BM denominam o processo de descentralização como School Based Management, que consiste em descentralizar a autoridade dos órgãos centrais para as escolas. Entre seus projetos para a educação, entre 2000 e 2005, 10,8\% foram direcionados a School 
Based Management, sendo que foi destinado 1,7 bilhão, correspondente a 22,9\% do montante aplicado em projetos educacionais (THE WORLD BANK, 2007).

Souza destaca que:

O gerenciamento dos recursos financeiros, na avaliação do banco, deve ser de responsabilidade mais descentralizada/desconcentrada, incentivando-se as instituições educacionais a se tornarem o mais autônomas possível. Este gerenciamento deve ser balizado por um conjunto de indicadores, padronizados por aquela metodologia gerencial que ficou conhecida como "gestão da qualidade". (SOUZA, 2003, p.20)

O BM considera, em seu documento, uma classificação de acordo com a intensidade de transferência de autonomia para as escolas, balizado por cinco elementos de descentralização: gestão de pessoal, gestão pedagógica, manutenção e infraestrutura, orçamento e acompanhamento e avaliação. O Quadro 1 ilustra a classificação:

Quadro 1 - Classificação do Banco Mundial para programas de descentralização

\begin{tabular}{|c|l|}
\hline $\begin{array}{c}\text { Classificação } \\
\text { (Very strong) }\end{array}$ & $\begin{array}{c}\text { Descrição } \\
\text { Controle quase total das escolas por seus conselhos ou administradores de } \\
\text { escola, que, inclusive, têm a possibilidade de criar novas escolas. }\end{array}$ \\
\hline $\begin{array}{c}\text { Forte } \\
\text { Strong) }\end{array}$ & $\begin{array}{l}\text { Alto grau de autonomia dado aos Conselhos de Escola sobre o orçamento, } \\
\text { pessoal etc.. Controle sobre os orçamentos (ou seja, as instituições } \\
\text { recebem financiamentos fixos ou subsídios). }\end{array}$ \\
\hline $\begin{array}{c}\text { Um pouco } \\
\text { forte } \\
\text { strong })\end{array}$ & $\begin{array}{l}\text { Os conselhos de escola têm autoridade para contratar e demitir } \\
\text { professores e/ou diretores e definir o currículo, mas possuem autonomia } \\
\text { limitada sobre finanças e controle de recursos. }\end{array}$ \\
\hline $\begin{array}{c}\text { Moderada } \\
\text { Moderate })\end{array}$ & $\begin{array}{l}\text { Os conselhos escolares foram criados, mas exercem um papel consultivo } \\
\text { ou têm autonomia limitada para o planejamento e fins estratégicos. }\end{array}$ \\
\hline $\begin{array}{c}\text { Fraco } \\
\text { (Weak) }\end{array}$ & $\begin{array}{l}\text { Sistema público de ensino é descentralizado para o nível municipal ou } \\
\text { regional, mas as escolas não têm praticamente nenhuma autonomia para } \\
\text { tomar qualquer decisão administrativa ou curricular. }\end{array}$ \\
\hline
\end{tabular}

Fonte: Elaborado pelo autor, com base no documento do BM (THE WORLD BANK, 2007). 
O programa de descentralização da Nova Zelândia é considerado um dos casos "fortes". As escolas não possuem autonomia apenas para interferir nos itens de decisão do calendário escolar, do estabelecimento de cobrança de mensalidades e da supervisão e avaliação dos professores (THE WORLD BANK, 2007).

Por outro lado, os processos desencadeados na Argentina e no Chile são classificados como "fracos", por possuírem processos de descentralização para os estados ou governos locais, mas não estabelecerem autonomia para as escolas (THE WORLD BANK, 2007).

O Brasil, segundo os critérios do BM, está classificado como "moderado", como aqueles que possuem conselhos escolares, mas apenas consultivos, sendo que dos elementos analisados apresenta somente os itens de supervisão orçamentária, atividades administrativas e decisões pedagógicas.

Dentre os argumentos apresentados pelos defensores da descentralização, a questão da qualidade do ensino é colocada como fator significativo para essa mudança organizacional dos sistemas educacionais. Casassus (1999), em seu artigo Descentralización de la gestión a las escuelas y calidad de la educación: ¿mitos o realidades?, traz importantes considerações sobre os impactos da descentralização na qualidade de educação. $\mathrm{O}$ autor afirma que não é possível discutir os impactos das estratégias adotadas pelas políticas educacionais na qualidade da educação sem antes discutir o que isso significa. Entendendo-se que qualidade é um termo complexo e também ambíguo, variando por qual objetivo se guia, pelo contexto histórico entre outros fatores. O autor faz distinção entre uma definição profissional, que tem objetivo pedagógico/curricular específico, e uma definição não profissional, que consiste em uma abordagem mais ampla, que não é medida, ou melhor, não é considerada em muitos dos processos avaliativos existentes.

Considerando que as estratégias propostas de descentralização difundidas na década de 1990 se fundamentam nos resultados das avaliações educacionais, em especial no que diz respeito ao rendimento escolar, Casassus (1999) contesta a ligação entre as estratégias de descentralização e a melhora de qualidade da educação. Para tanto, destaca que na literatura voltada para a questão são poucos os estudos que analisam essa relação e os que o fazem não possibilitam que se estabeleça associação entre a estratégia de descentralização e a melhoria da qualidade. O autor considerou os estudos preliminares do Estúdio Internacional Del Laboratório Latinoamericano de Evaluación de La Calidaded em Educación, com avaliação focada na linguagem e matemática, e o estudo internacional do Tercer Estúdio de Matemática y Ciência (Timss), que avaliou o desempenho de estudantes nas áreas de ciências e 
matemática, e constatou que os melhores índices de acertos pertenciam a países de organização centralizada.

Para aprofundar a complexidade da questão, discute os resultados do Chile nos Sistemas de Medición de la calidad de la educación de Chile (Simce), em que as escolas privadas tiveram os melhores resultados, seguida pelas escolas subvencionadas. As escolas públicas tiveram os piores resultados nessa avaliação. Do ponto de vista do rendimento escolar pode-se entender que a gestão privada produz melhores resultados. Contudo, deve-se ponderar que as instituições privadas e subvencionadas podem selecionar os alunos, garantindo altos índices de rendimento, enquanto que as públicas atendem às classes mais populares e aos alunos “rejeitados" pelas escolas privadas (CASASSUS, 1999).

Barroso (1996), ao se reportar à estratégia de descentralização, classifica-a em duas frentes: de fundamentação científico-pedagógica e de fundamentação político-gestionária. Os argumentos baseados na primeira partem da tentativa de aplicação dos resultados, frutos das pesquisas nas "escolas eficazes".

$\mathrm{O}$ autor destaca duas gerações de pesquisas, derivadas dessa fundamentação. A primeira é originária dos esforços em medir os efeitos dos programas de democratização e integração racial nos EUA, no final dos anos 50. Essa geração opta por seguir um modelo de análise por input-output, portanto não consistia em examinar os processos no interior das escolas, mas sim observar os resultados obtidos pelos alunos nos exames e pela escola que eles frequentavam. Os estudos apontaram para uma interferência inexpressiva nos resultados em relação à maneira como eram alocados os recursos.

A segunda geração de estudos não considera a escola como "unidade de produção", mas a enxerga como "organização social", fazendo uma crítica à fase anterior, principalmente aos exames de inteligência usados como medida e ao sistema de input-output, que desconsiderava os processos escolares interessando somente os resultados do produto final. Assim, optam por adentrarem nas escolas na busca de indicadores para seus estudos, obtendo, dessa forma, modelos de "escolas eficazes". O autor também destaca que algumas administrações, em especial os EUA e a Inglaterra, tomam os resultados como modelos de "escola ideal" e os transformam em programas para as demais escolas, sem considerar uma análise mais substancial desses estudos (BARROSO, 1996).

$\mathrm{Na}$ abordagem político-gestionária, os que defendem essa estratégia de gestão, apoiados nos argumentos da "eficiência" e "eficácia", propõem que a lógica da competição e da concorrência sejam elementos propulsores da melhora na qualidade da educação. Com isso, 
há um forte investimento na transferência de práticas gerenciais de empresas para as escolas. $\mathrm{O}$ autor destaca que, mesmo entre os defensores desse tipo de descentralização, há a necessidade de algum controle:

\footnotetext{
Esta é uma situação paradoxal (o Estado cria o mercado, mas não confia totalmente nele) que vários autores têm analisado no quadro do que definem ser um "sistema escolar como um sistema de economia mista" (ver a este propósito Thomas, 1994). Isto é, um sistema em que se procura conciliar as "chamadas" vantagens do mercado (a competição e a racionalidade econômica) com as vantagens do não-mercado (facilidades do controlo e da subordinação a certas normas), permitindo assim, no dizer dos seus defensores satisfazer, simultaneamente, os "interesses individuais" e os "interesses coletivos".

$[\ldots]$

Contudo, nos tempos actuais, o que é mais significativo nesta preocupação gestionária não é a importância que é dada à gestão, mas sim o facto de se pretender reduzir os problemas das escolas a problemas de gestão, como forma de escamotear a complexidade da escola enquanto organização e conflitualidade ideológica, política e social a ela inerentes. (BARROSO, 1996, p. 182-184)
}

Como se pode observar, a discussão sobre a descentralização nas políticas educacionais tem estado em questão em seus diferentes aspectos.

\subsection{A descentralização de recursos financeiros}

A descentralização de recursos financeiros na educação (mas também podem ser entendidas em outras áreas) pode ser observada por diferentes lentes. Pode-se considerar seu processo de transferência de recursos dos governos centrais para os governos regionais ou locais, de órgãos centrais para órgãos periféricos, ou mesmo da transferência direta às escolas.

É importante destacar que a descentralização de recursos financeiros para as escolas não necessariamente ocorre em sistemas descentralizados, ou que não se possa ter transferência de recursos em sistemas centralizados. Além de não haver empecilhos para que governos centrais repassem recursos diretamente para escolas, sob responsabilidade de governos regionais ou locais, adiante será mostrado um exemplo dessa forma, no caso brasileiro, com o Programa Dinheiro Direto na Escola.

A descentralização financeira pode ser realizada de diversas formas. Pode ter caráter meramente administrativo, com o objetivo de desafogar a administração central ou local, ou reduzir os processos burocráticos. Assim, é uma ação com vistas a atender de forma mais rápida as necessidades do cotidiano, no caso escolar, sem atender às exigências que os órgãos 
centrais possuem para realização de gastos que, por vezes, tornam o processo complexo e moroso. Ainda assim, os órgãos, as instâncias administrativas, ou governos locais e centrais, podem deter o controle sobre as formas e orientações dos gastos.

Contudo, pode trazer ainda uma possibilidade de maior autonomia. A transferência de recursos pode abarcar ou estar atrelada a uma política de descentralização também da tomada de decisão.

Ao analisar as políticas de descentralização de recursos financeiros, um dos elementos a serem observados é se seu caráter está mais ligado a uma perspectiva de desconcentração ou de autonomia. No entanto, cabe ressaltar desde já que, assim como se alertou anteriormente, a perspectiva de desconcentração e a de autonomia não são necessariamente opostas ou contraditórias e, inclusive, podem coexistir.

Voltando-se o olhar para como a questão da descentralização de recursos financeiros para as escolas tem se apresentado no Brasil, no que tange à autonomia de gestão financeira das escolas, Polo (2001) destaca que a formulação apresentada na LDB/96, no artigo 15, tem por finalidade garantir que a escola, sendo reconhecida como instituição fundamental da educação, não seja sempre dependente das administrações dos sistemas de ensino e seus processos muito lentos. Entretanto, essa autonomia não tem o intuito de estabelecer total independência das escolas.

Com isso, o autor entende que a autonomia de gestão financeira deve estar atrelada ao princípio da gestão democrática presente na $\mathrm{CF} / 88$ e na LDB/96:

\begin{abstract}
Assim, é esse princípio democrático que deve ser o orientador maior das diversas formas que a autonomia financeira pode vir a tomar nas diferentes escolas e diferentes municípios. Desse princípio não se pode fugir, e é dele que deve vir a inspiração para tornar todos os atos relacionados com o planejamento e o uso dos recursos financeiros em atos de aprendizagem e de exercício da cidadania. (POLO, 2001, p. 283)
\end{abstract}

Algumas formas de descentralização de recursos financeiros para as escolas foram implementadas no Brasil. Uma delas é o Programa Dinheiro Direto na Escola (PDDE), iniciativa do governo federal com recursos oriundos do Salário-Educação ${ }^{9}$, com o objetivo de repassar recursos para as escolas, de acordo com o número de alunos matriculados no ensino fundamental $^{10}$, havendo distinção pela região onde se localizam as escolas, como forma de

9 Ver OLIVEIRA, R. P. de. O Financiamento da Educação. In: ADRIÃO, T. (Orgs.). Gestão, financiamento e direito à educação. São Paulo: Xamã, 2007.

${ }^{10}$ Após a aprovação do Fundeb, o programa passou a destinar recursos também para as creches e pré-escolas. 
discriminação positiva. O valor destinado às escolas do Norte, Nordeste e Centro-Oeste é superior ao das regiões Sul e Sudeste e do Distrito Federal. Os recursos podiam, inicialmente, ser utilizados apenas para custeio das despesas escolares. Vale ressaltar que vários estados e municípios criaram seus próprios programas influenciados por esse modelo de descentralização de recursos financeiros.

Em relação a esse tipo de transferência de recursos destinados diretamente para as escolas, Peroni (2006) apresenta algumas preocupações, por exemplo, a forma que o PDDE estabelece para que as escolas recebam os recursos.

Desde a sua criação, em 1995, quando ainda se chamava Programa de Manutenção e Desenvolvimento do Ensino Fundamental (PMDE), até 1997, o recebimento de recursos pelas Unidades Executoras $^{11}$ (UEx) era uma possibilidade. Entretanto, em 1997, passa a ser condicionado à criação de tais figuras jurídicas. Assim, para a autora, ao

[...] analisamos a obrigatoriedade de todas as escolas terem unidades executoras para receber os recursos da União, verificamos que, por um lado, há uma centralização por parte do ente federativo União, retirando a autonomia dos municípios e estados de construírem seus processos de gestão democrática e, por outro lado, um avanço no processo de implantação de organizações sociais, que são parte da passagem das políticas públicas para o público não-estatal, entendido no Plano Diretor da Reforma do Estado como descentralização da execução de políticas sociais, do Estado para a sociedade. (PERONI, 2006, p. 342)

Igualmente, Peroni (2006) questiona a forma de implementação de políticas públicas, por meio do público não estatal, que pode configurar uma desresponsabilização do Estado. Somado a isso, tem-se, novamente, a possibilidade da contaminação da lógica de mercado para a educação. Outro problema desse tipo de descentralização de recursos financeiros, que foi dado no Brasil, liga-se à possibilidade de captação de recursos pelas UEx.

Em seus estudos, Souza (2006) traz importante contribuição sobre a questão do público versus privado na descentralização de recursos financeiros. As APMs, forma mais difundida no Brasil para o gerenciamento de recursos descentralizados, também é responsável por diversos tipos de arrecadação, como bingos, festas, sorteios, entre outros, como a cobrança de taxas, maneira muito complicada que a APM lança mão, mas, na medida em que é uma associação, pode cobrar de seus associados. Isso, de alguma forma, abre espaço para condicionar o direito à educação ao pagamento de taxas. Evidentemente, condicionar, de

\footnotetext{
${ }^{11}$ Unidade Executora é uma nomenclatura adotada pelo Ministério da Educação (MEC) para as entidades da sociedade civil de direito privado e sem fins lucrativos, ligadas às escolas públicas, como exemplo podemos encontrar: Caixa Escolar, Associação de Pais e Professores, APM e Círculo de Pais e Mestre.
} 
qualquer forma, o direito à educação a alguma contribuição para as APMs é ilegal e fere a $\mathrm{CF} / 88$ e a LDB/96.

O autor questiona a característica desses recursos, se são públicos ou privados. Assim, entende que podem ser compreendidos de dois modos: privados, fugindo da natureza da escola pública; ou "quase públicos", uma vez que a arrecadação só se efetiva pelo caráter público da escola e, em geral, está ao seu serviço.

Desta forma, se compreendermos os recursos arrecadados pela escola como recursos privados, teremos que combater sua presença no interior da escola. Se compreendermos tais recursos como recursos quase públicos, precisaríamos discutir a necessidade, e quiçá o próprio poder público, controlar sua arrecadação e sua aplicação. (SOUZA, 2006, p. 258)

Entretanto, Souza (2006) considera que se o poder público optasse por atender as necessidades mais cotidianas das escolas, que por vezes é o maior impulsionador da arrecadação própria, não seria grande o esforço da parte do poder público para suprir essa complementação.

Outra forma de descentralizar recursos para as escolas no Brasil pode ser realizada por meio de regime de adiantamento, quando os recursos destinados são entregues ao servidor, como previsto na Lei federal 4.320/1964, com o objetivo de evitar o trâmite demorado de compras. Assim, respeitando a determinação da legislação local, poderá o diretor, por exemplo, fazer pequenos reparos no prédio; comprar materiais escolares e pedagógicos ou materiais de limpeza e higiene não existentes no almoxarifado; contratar pequenos serviços, inclusive palestras, e transporte para atividades externas etc. (POLO, 2001).

Entretanto, a utilização dessa estratégia possui algumas questões complexas. Se, por um lado, não se tem a complicação da destinação de verbas para instituições de direito privado, por outro, ao ser entregue sob a responsabilidade de um servidor, pode advir um entendimento de que, em virtude de este responder nominalmente pelo recurso, tem o direito de decidir sobre como será a sua utilização, ou ainda, no temor de utilizá-lo de forma inapropriada, simplesmente não o faz.

Polo (2001) traz proposições sobre a aplicação dessa estratégia. Como a lei determina que o regime de adiantamento deve ser regulamentado por lei local, o autor oferece proposta de minuta, para servir de base para que os prefeitos possam discutir a regulamentação do mecanismo de descentralização de recursos. 
Com o intuito de garantir um processo mais participativo, Polo sugere que "a utilização dos recursos definidos para cada escola deverá ser objeto de um plano de aplicação a ser elaborado pelo respectivo diretor, ouvido o Conselho Escolar" (POLO, 2001, p. 292). No entanto, mesmo estabelecendo que o conselho seja ouvido, não há garantias de que a decisão sobre a utilização do recurso seja definida por esse órgão coletivo da escola.

Outra forma possível de descentralização de recursos financeiros para as escolas é transformar o Conselho de Escola em pessoa jurídica e celebrar convênio com as secretarias de educação. Santo André optou por essa última forma, aprovando a Lei 8.376, de 27 de junho de 2002.

\begin{abstract}
Art. $1^{\circ}$ - O artigo $1^{\circ}$ da Lei $n^{\circ} 7.854$, de 30 de junho de 1999, passa a vigorar com a seguinte redação:

"Art. $1^{\circ}$ - Fica instituído o Conselho de Escola, sociedade civil com personalidade jurídica própria, sem fins lucrativos, vinculado a cada unidade escolar municipal, com espaço supremo de decisões, de acordo com o artigo 257 da Lei Orgânica do Município, artigo 45 do Capítulo XV do Estatuto do Magistério, artigo 205 do Capítulo III da Constituição Federal e artigo 14, inciso II, da Lei $n^{\circ}$ 9.394/96, que institui as Diretrizes e Bases da Educação Nacional." (SANTO ANDRÉ, 2002)
\end{abstract}

Posteriormente, o município aprovou também a Lei 8.805, de dezembro de 2005, que autoriza convênios com os Conselhos de Escola para descentralizar recursos financeiros para as escolas.

\begin{abstract}
Art. $1^{\circ}$. Fica o município de Santo André, por intermédio da Secretaria de Educação e Formação Profissional, autorizado a celebrar convênios com os Conselhos de Escola, instituídos pela Lei $\mathrm{n}^{\circ} 7.854$, de 30 de junho de 1999 , alterada pela Lei ${ }^{\circ}$ 8.376 , de 27 de junho de 2002, objetivando a gestão de recursos financeiros repassados pelo Município, para o atendimento de despesas de pequeno vulto, na unidade escolar a que tiver vinculado o Conselho. (SANTO ANDRÉ, 2005)
\end{abstract}

Essa opção por transformar o CE em pessoa jurídica pode auxiliar em dois problemas: o conflito de atribuições na existência de dois espaços de tomada de decisão (CE e APM) e a distorção da representatividade em decorrência das composições dos dois espaços.

\title{
2.5. Espaços de tomada de decisão
}

Pode-se dizer que a política de descentralização de recursos financeiros para as escolas é uma política de intersecção, a qual abarca, primeiramente, o encontro de duas grandes áreas, 
a da gestão escolar e a do financiamento da educação. Outro cruzamento está na característica de tal política de pressupor dois âmbitos de tomada de decisão, as decisões do Estado, de forma mais geral, e as decisões locais.

No capítulo 3, será observada a questão da tomada de decisão do ponto de vista mais geral. Neste item, pois, analisam-se os espaços de tomada de decisão local, no caso nas escolas, e sua relação com a gestão democrática.

$\mathrm{Na}$ perspectiva de discutir como o PTRF impacta a gestão democrática das escolas, faz-se necessário refletir sobre o exercício de poder dentro das escolas.

Para Max Weber, há distinção entre poder e dominação.

Entende-se por poder a oportunidade existente dentro de uma relação social que permite a alguém impor a sua própria vontade mesmo contra a resistência e independentemente da base na qual esta oportunidade se fundamenta.

Por dominação entende-se a oportunidade de ter um comando de um dado conteúdo específico, obedecido por um dado grupo de pessoas. (WEBER, 2002, p. 97)

Segundo Paro, o poder ${ }^{12}$ pode ser entendido em duas perspectivas: "como capacidade de agir sobre as coisas e o poder como capacidade de determinar o comportamento de outros" (PARO, 2008, p. 32). E pode se manifestar de três modos: coerção, manipulação e persuasão. A coerção acontece quando um obedece às vontades do outro, por meio da coação ou ameaça; a manipulação, quando um induz o outro a suas necessidades/vontades, ocultando seus reais interesses e informações; e a persuasão parte da premissa do convencimento do outro de sua ideia/vontade, distinguindo-se da manipulação pela exposição dos seus interesses para o convencimento, o que pressupõe a possibilidade de acontecer o inverso, sendo ele convencido.

A seguir, apresenta-se uma breve descrição e análise de três espaços (não são os únicos espaços) de exercício do poder nas escolas: a Direção Escolar, os Conselhos de Escola e, por fim, as APMs.

Na rede municipal de ensino de São Paulo, diretor de escola é um cargo com ingresso por meio de concurso de provas e títulos. Após a aprovação da Lei 14.660/2007, o provimento do cargo se mantém por concurso, só que exclusivamente por acesso de professores que já compõem o quadro do magistério da rede municipal.

Paro (2003, p. 19) destaca que um dos argumentos tradicionalmente empregados para a defesa do provimento do cargo de diretor de escola, por meio de concurso, está ligado à

\footnotetext{
12 Paro (2008), em seu texto, trata apenas do conceito de poder na perspectiva do homem como sujeito desse processo, deixando de lado os aspectos do poder relacionado às coisas e fenômenos naturais.
} 
"defesa da moralidade pública na escolha dos funcionários do Estado e com a adoção de critérios técnicos para preenchimento dos cargos". O autor identifica que, na literatura, as principais virtudes encontradas em defesa do concurso público são a objetivação, a contenção do clientelismo e mensuração do conhecimento técnico.

É sobre esse aspecto que a ocupação dos cargos de diretor escolar, por meio de concurso, ganha força no interior da rede municipal de ensino, pois na sua origem ocupar funções por "apadrinhamento político" se mostrou muito danosa à rede e provocou muita tensão entre os servidores (FICHMANN, 1988).

Contudo, Paro (2003) destaca também as insuficiências do concurso, na medida em que se mostra ineficaz para aferir a capacidade de liderança e legitimidade perante os trabalhadores das escolas e seus usuários.

No processo de escolha, por concurso, estabelece-se a vinculação do diretor à escola como um direito do ocupante do cargo. Após optar pela unidade educacional de lotação, o servidor somente sairá da instituição de ensino por aposentadoria ou processo de concurso de remoção, o que só ocorre se ele assim o desejar e se inscrever. Isso contribui para que as necessidades da comunidade escolar sejam postas de lado.

Para quem examina em profundidade o funcionamento real da escola pública onde o concurso para o cargo de diretor é a regra [...] não é difícil perceber a intensidade com que essa estabilidade quase vitalícia do cargo concorre para determinar o descompromisso do diretor com objetivos educacionais articulados com interesses dos usuários e induz à negligência para com formas democráticas de gestão. (PARO, 2003, p. 24)

Nessa condição de escolha do diretor de escola por concurso eleva-se o caráter técnico da função. Retoma-se aqui a discussão, apresentada no capítulo 1, de que não basta a incorporação das pessoas no processo, é necessário também que haja condições reais para se decidir. Bobbio considera que:

Tecnocracia e democracia são antitéticas: se o protagonista da sociedade industrial é o especialista, impossível que venha a ser o cidadão qualquer. A democracia sustenta-se sobre a hipótese de que todos podem decidir a respeito de tudo. A tecnocracia, ao contrário, pretende que sejam convocados para decidir apenas aqueles poucos que detêm conhecimentos específicos. (BOBBIO, 2009, p. 46)

Camargo, com base nas considerações de Paro sobre os condicionantes institucionais, diz que o diretor, 
[...] ao ser considerado como a autoridade máxima da escola, o mesmo passa a ser o "culpado primeiro" e não o "responsável último". Por isso centraliza as decisões, atendendo um excesso de exigências burocráticas (sendo levado a considerar quase tudo o que ocorre na escola, aparentemente, como uma questão técnica e não política). Por este procedimento, é ele um dos que mais dificultam o estabelecimento de relações democráticas e a participação da comunidade na escola, fazendo com que as pessoas se voltem contra a pessoa do diretor e não contra a natureza de seu cargo. (CAMARGO, 1997, p. 165, grifo do autor)

Aqui se observa uma primeira tensão no interior das escolas em relação à direção escolar e ao estabelecimento de uma gestão democrática. Então, torna-se necessário o exame de algumas questões sobre outros dois espaços de tomada de decisão no interior das escolas municipais. Por isso, a análise se volta, inicialmente, para os Conselhos de Escola, na medida em que hoje se caracterizam como instâncias máximas de decisão no interior das unidades educacionais; depois, para as APMs, essas como entidade auxiliar da escola.

Segundo Camargo (1997), no sistema de ensino municipal de São Paulo, a primeira aparição em norma legal dos Conselhos de Escolas ocorre com a aprovação da Portaria 9517, de 30 de dezembro de 1982. O autor afirma que se tratava de uma elaboração de gabinete, com a concepção de uma participação controlada e o caráter do conselho de escola era consultivo.

Em 1985, na gestão de Mario Covas Junior, houve uma reformulação do Regimento Comum das Escolas Municipais (RCEM). Embora, por um curto período, apenas dois dias, houve discussão nas escolas e possibilidade de apresentarem propostas de alteração. Esse processo resulta no Decreto 21.811/1985, constando no texto o caráter deliberativo do Conselho de Escola (PEPE, 1995).

Outro elemento importante, presente no regimento de 1985, pode ser ilustrado na afirmação de Pepe:

\footnotetext{
Pela primeira vez estabeleceu-se a diferença entre gestão e direção da unidade escolar. A primeira compreendia o processo de elaboração de metas e diretrizes para a atividade escolar, bem como o acompanhamento e avaliação das mesmas. No entanto, não era especificado o instrumento a ser utilizado para tais ações. Já a direção da escola era entendida como o processo de integração das ações desencadeadas na escola, sendo exercida pelo Diretor da unidade escolar. A gestão da escola englobava sua direção. Nas entrelinhas evidenciava-se a dimensão política da gestão escolar. (PEPE, 1995, p. 31):
}

Contudo, a eleição de Jânio Quadros para a prefeitura retrocede as conquistas. É revogado o Decreto 21.811/1985 e volta a vigorar o texto de 1982. Pepe (1995) mostra que, segundo os interesses da gestão em questão, opta-se por investir em obras viárias, chegando a 
ignorar a vinculação constitucional de aplicação dos $20 \%$ em educação e se restabelece fortemente a hierarquia e a centralização na Secretaria Municipal de Educação. A autora destaca que os professores manifestaram seu descontentamento com as alterações, o que levou o professorado da rede municipal a uma greve de 19 dias. A gestão da prefeitura reprimiu violentamente e perseguiu os manifestantes e diretores, que se negaram a entregar os nomes dos grevistas.

Posteriormente, a gestão de Luiza Erundina (1989-1992), na época filiada ao Partido dos Trabalhadores (PT), aprova o RCEM de 1991. Houve ampla participação da comunidade escolar, conforme Pepe:

\begin{abstract}
O processo de apreciação pelas escolas da versão preliminar constou de 4 etapas. A primeira, envolvendo todos os segmentos da comunidade escolar - trabalhadores em educação e usuários - consistiu na apresentação e na discussão do novo texto em reuniões por escola coordenadas pelas equipes de NAEs. A segunda consistiu na discussão e levantamento de dúvidas, organizada e restrita aos membros da comunidade escolar da qual foram eleitos 2 representantes por escola (um da equipe escolar e outro de usuários) para compor uma plenária regional de caráter deliberativo, coordenadas pelos respectivos NAEs e onde as propostas de cada escola foram apresentadas e defendidas por seus representantes. Deste fórum saíram 10 representantes eleitos responsáveis por apresentar e defender as propostas de suas regiões num fórum municipal. Esta última instância foi coordenada pela DOT e composta pelos representantes regionais, por entidades da sociedade civil que acompanharam o processo e por membros do governo. (PEPE, 1995, p. 72-73)
\end{abstract}

De outro lado, em 1992, por meio da Lei 11.229, de 26 de junho de 1992, é aprovado o Estatuto do Magistério da rede municipal de São Paulo, que também traz a caracterização do Conselho de Escola como deliberativo e suas competências muito próximas às estabelecidas no Regime Comum de 1991.

Em 2007, a aprovação da Lei 14.660, que consolida o Estatuto dos Profissionais da Educação Municipal, mantém a definição do Conselho de Escola, conforme o seu artigo 117, como "colegiado com função deliberativa e direcionada à defesa dos interesses dos educandos e das finalidades e objetivos da educação pública do Município de São Paulo.” (SÃO PAULO, 2007a).

No Estatuto do Magistério (Lei 11.229/1992), o artigo 109 define as competências dos Conselhos de Escola, estabelecendo 14 atribuições. Em 2007, com a aprovação da Lei 14.660, o artigo 117 é que passa a defini-las, com 13 atribuições.

Comparativamente, a maior parte das atribuições é igual. Contudo, destacam-se duas diferenças importantes: a primeira está presente no item VI das leis. No Estatuto de 1992, competia ao conselho escolher servidores que ocupariam certas funções, entre elas a de 
assistente de direção, já na Lei 14.660, essa competência recai sobre o diretor de escola (Anexo I da Lei 14.660/2007). A alteração significa uma redução de poder que os Conselhos de Escola tinham sobre a direção das escolas. A segunda diferença é a ausência do item XIV na Lei de 2007, que estabelece como competência dos Conselhos de Escola eleger os representantes para o Colegiado Regional de Representantes de Conselhos de Escola (Crece).

\begin{abstract}
O Crece era uma instância regional, não institucionalizada, porém incentivada pela administração petista, entendido como um canal de participação e comunicação dos representantes de Conselhos de Escola entre si e com a SME (e vice-versa), um espaço de exercício da cidadania e organização da população, um espaço de trocas sobre a forma e o funcionamento das escolas e de seus CEs numa dada região e um espaço de discussão de problemas das escolas e proposição de alternativas, inclusive estabelecendo, em conjunto com o NAE [Núcleo de Ação Educativa], as prioridades da região. (CAMARGO, 1997, p. 185)
\end{abstract}

Assim, pode-se dizer que, por um lado, os Conselhos de Escola se mantiveram como instâncias de deliberação das escolas, mas por outro lado houve uma redução das atribuições e a retirada de um canal (os Creces) de formação, troca de experiências e espaço para expor os problemas, que muitas vezes são sufocados no interior da escola por não ter, ou serem muito restritos, os meios para isso.

Cabe ressaltar que em ambas as leis está presente a competência dos Conselhos de Escola de decidir sobre procedimentos relativos à priorização de aplicação de verbas.

Os recursos financeiros (em sua maioria), porém, são arrecadados por instituições auxiliares das escolas, ou transferidos a estas pelo Poder Público. No caso da rede municipal de ensino de São Paulo, são as APMs as instituições auxiliares. Examina-se, agora, um pouco da história dessas entidades e suas atribuições.

Bueno (1987) escreve sua tese de doutorado sobre as APMs na escola pública do Estado de São Paulo. A autora diz que, embora não se tenha de forma muito precisa informações sobre a existência de APMs antes da década de 1930, é a partir das reformas do ensino estabelecidas por Lourenço Filho, em 1931, que se localiza precisamente a existência das APMs nas escolas do Estado de São Paulo.

Cabe ressaltar que, nesse momento, não existe a rede municipal de ensino de São Paulo. Entretanto, na década de 1940, são firmados dois convênios entre o município e o governo do estado. O primeiro tem duração entre os anos de 1943 a 1948, com o objetivo principal de ampliar os parques infantis. O segundo convênio, vigente no período de 1948 a 1951, foca-se na ampliação do atendimento a demanda pelo ensino primário (PEPE, 1995). 
Em 1953, a partir do estabelecimento de eleições diretas para prefeito, acirram-se as disputas entre os governos estadual e local (FICHMANN, 1988; PEPE, 1995).

Em 1954, Jânio da Silva Quadros, ex-prefeito da capital, é eleito governador pela coligação PTN (Partido Trabalhista Nacional) e PSB (Partido Socialista Brasileiro), estando à frente da prefeitura da cidade Lino de Matos, senador pelo Partido Social Progressista (PSP), licenciado para o exercício no executivo e vinculado a Adhemar de Barros, histórico opositor do então governador. Como consequência da ferrenha disputa e enfretamento entre os dois níveis de governo, envolvendo inclusive denúncias de ambas as partes quanto à efetivação de suas responsabilidades nos convênios para instalação do ensino primário, o terceiro convênio é inviabilizado. (PEPE, 1995, p. 14)

Em meio ao crescimento desenfreado da população na metrópole, aos conflitos entre o poder estadual e o municipal, e à vinculação orçamentária da Constituição Federal de 1946, o Decreto 3.185, de 2 de agosto de 1956, só então institui o ensino municipal.

Assim, o processo de surgimento das APMs na rede estadual também é base para a formação delas no ensino municipal. Bueno (1987) destaca que as APMs faziam parte dos fundamentos da reforma conduzida por Lourenço Filho, que se apoiava nos ideais escolanovistas.

\footnotetext{
É que a criação de instituições auxiliares da escola era ingrediente necessário e imprescindível para a realização das propostas escolanovistas, e as Associações de Pais e Mestres, por terem um papel fundamental a cumprir na concretização da "escola socializada" - a escola em estreita conexão com o meio social, tal como preconizavam os ideólogos do movimento renovador - gozaram de relevância entre as demais. (BUENO, 1987, p. 15-16, grifos da autora)
}

Naquele momento, a essas APMs não são estabelecidos estatutos ou normas padronizadas ou rígidas, apenas oito diretrizes gerais: sugerir ao menos a criação de uma APM em cada município; formular regulamentação especial de acordo com as condições locais e sem obrigação de qualquer contribuição em dinheiro para os pais participarem; constituir um conselho diretor de sete membros (quatro pais e três professores em exercício); promover a manutenção e o desenvolvimento de instituições auxiliares: caixas de assistência e cooperativas; melhoria das escolas e encaminhamento dos alunos concluintes para novos estudos ou aprendizado de profissão; realizar reuniões ao menos uma vez por mês sobre higiene e puericultura; possibilidade de a direção ou os professores exporem os processos educativos realizados nas escolas para despertar o interesse dos pais; possibilidade de escolha, semestral ou anualmente, de um problema particular da localidade para tratar; e publicação 
dos trabalhos produzidos pelas APMs, como forma de incentivo e considerados como relevantes (BUENO, 1987).

Das diretrizes estabelecidas, fica clara a preocupação com a aproximação dos pais com o trabalho da escola e salta aos olhos o fato de estabelecerem que o Conselho Diretor da APM tivesse na sua composição a maioria de pais.

O entusiasmo com o trabalho das APMs se restringe à gestão de Lourenço Filho, à frente da Diretoria de Ensino Estadual. Segundo Bueno (1987), em 1931, são registradas 1.002 associações; em 1933, o número era de apenas 340, o que significa que muitas delas apenas foram fundadas, mas não funcionaram. Segue à gestão de Lourenço Filho (27/10/1930 - 23/11/1931), a de Sud Mennucci (24/11/1931 - 26/5/1932), que não partilhava dos mesmos ideais do seu antecessor, por isso, não dá prosseguimento ao seu trabalho. Já na gestão de Fernando de Azevedo (28/12/1932 - 25/7/1933), é publicado o Código de Educação do Estado de São Paulo, com o objetivo de resgatar os princípios de Lourenço Filho.

O Código trazia, em seu texto, os elementos presentes nas diretrizes de 1931. Contudo, fica de fora o caráter de flexibilização às condições locais. Ao contrário, estabelece-se um caráter mais burocrático e padronizador.

Diferentemente, ou talvez traindo os objetivos aparentes da primeira proposta, deslocou a ênfase para a constituição de patrimônio financeiro e sobre sua forma de aplicação, que deveria ser, desde que possível, em bibliotecas, gabinetes dentários, assistência médica e "prêmio em dinheiro para o melhor aluno de cada seção". (BUENO, 1987, p. 25, grifos da autora)

A autora, no entanto, diz que o fato de as associações não vingarem está relacionado a fatores mais amplos. Os objetivos de criação das associações estão intimamente ligados e condizentes com os objetivos escolanovistas, mas

\footnotetext{
A evolução dos fatos mostrou que esse projeto estava assentado em bases falsas. O Brasil, tendo se encaminhado para uma formação social extremamente estratificada, não favoreceu a democratização da sociedade e, por conseguinte, da escola. Os renovadores percebiam as desigualdades sociais, mas desejavam adequar a escola à nova ordem social, sem questioná-la. Voltavam-se contra a escola tradicional, mas não contra o Estado Burguês. Por isso geraram tantas inconsistências. (BUENO, 1987, p. 38)
}

Por outro lado, as Caixas Escolares, que consistiam em instituições auxiliares com o objetivo principal de captar recursos para as escolas, mantiveram-se presentes e por serem espaços fortemente burocratizados não interferiam nas questões educacionais. Em 1941, tornam-se obrigatórias nos grupos escolares estaduais. 
No decorrer dos anos, as associações vão deixando de lado as questões educacionais e se estruturando como alternativa, de forma similar às Caixas Escolares, para a captação de recursos financeiros, uma vez que os recursos oriundos dos poderes públicos não acompanham a crescente ampliação da demanda pelo ensino.

Paulatinamente a obrigatoriedade de contribuir foi se instalando nos períodos de matrícula e a tal ponto que as contribuições passaram a ser designadas naturalmente como taxas. Isto é, elas passaram a ter o sentido de um tributo e não mais de uma contribuição. (BUENO, 1987, p. 76)

Um dos efeitos das arrecadações obrigatórias nas escolas é sintetizado pela autora: "Daí o círculo vicioso que se inicia: escolas de clientelas pobres, APMs pobres, ensino deficiente, escolas de clientelas ricas, APMs ricas, melhor atendimento ao ensino." (BUENO, 1987, p. 76).

Bueno (1987) relata inúmeras denúncias feitas sobre as cobranças de taxas pelas escolas e o desvirtuamento da função das APMs. Somente em 1983, os estabelecimentos oficiais de ensino são proibidos de cobrarem taxas.

O histórico das APMs no estado de São Paulo dá uma ideia das tensões vividas entre essas entidades e as escolas. A criação da rede de ensino municipal só é realizada em 1956, mas herda essas tensões apresentadas entre as escolas e as entidades auxiliares.

Mais adiante, em 1997, por conta da criação do PDDE, passa-se a ser exigir das escolas a criação de uma UEx para o recebimento dos recursos financeiros do programa. Esse movimento generaliza algumas atribuições das APMs. As UEx, entidades da sociedade civil, constituídas de pessoa jurídica de direito privado, sem fins lucrativos, apresentam as seguintes atribuições:

\footnotetext{
Administrar recursos transferidos por órgãos federais, estaduais, distritais e municipais;

Gerir recursos advindos de doações da comunidade e de entidades privadas;

Controlar recursos provenientes da promoção de campanhas escolares e de outras fontes;

Fomentar as atividades pedagógicas, a manutenção e conservação física de equipamentos e a aquisição de materiais necessários ao funcionamento da escola; e Prestar contas dos recursos repassados, arrecadados e doados. (BRASIL, 2009a, p.3)
}

A preocupação das atribuições das UEx está ligada à forma de gerir os recursos destinados pelo Poder Público (do município, do estado e da União), bem como sua captação de outras fontes. Não está expresso a quem compete decidir sobre cada item a que lhe foram designadas atribuições. 
Em 2005, o município, por meio do Decreto 46.230, de 23 de agosto de 2005, que regulamenta o PTRF, estabelece, em Anexo Único, o Termo de Compromisso a ser firmado entre a SME e as APMs, o qual traz como obrigações das associações:

\footnotetext{
São obrigações da Associação de Pais e Mestres, enquanto unidade executora do PTRF:

I - aplicar os recursos recebidos exclusivamente na execução do objeto deste Termo de Compromisso na unidade beneficiária até o último dia útil do período;

II - zelar para que o custo dos serviços e materiais adquiridos sejam compatíveis, em valor e qualidade, com os praticados no mercado;

III - apresentar à unidade gestora, a cada período, prestação de contas da aplicação dos recursos recebidos na forma estabelecida mediante portaria editada pela Secretaria Municipal de Educação;

IV - manter à disposição das unidades da Secretaria Municipal de Educação e demais órgãos de controle da Administração Municipal, pelo prazo de 5 (cinco) anos, a contar da aprovação das contas pela unidade gestora e de controle, em boa ordem, os documentos comprobatórios das despesas realizadas com os recursos recebidos;

V - afixar nas dependências da escola, em local visível e de acesso ao público, o Quadro Demonstrativo de Aplicação dos Recursos;

VI - manter registros específicos do fluxo de recursos recebidos à conta do PTRF, destacando a receita, as eventuais aplicações financeiras e os respectivos rendimentos, bem como as despesas realizadas;

VII - devolver, no prazo determinado e por meio de processo administrativo, os valores transferidos nos seguintes casos:

a) quando não forem aplicados para a finalidade a que se refere o objeto deste instrumento;

b) omissão de prestação de contas no prazo exigido, salvo quando decorrente de caso fortuito ou motivo de força maior devidamente comprovados. (SÃO PAULO, 2005a).
}

Observa-se que as obrigações das APMs têm caráter burocrático administrativo em relação aos recursos do PTRF. São preocupações muito importantes para se garantir minimamente o controle dos gastos de recursos públicos, sobretudo por se tratar de transferência para entidades de direito privado sem fins lucrativos. Contudo, não se nota a mesma preocupação para garantir o controle dos próprios usuários. A unidade gestora, à qual a APM tem que reportar a prestação de contas, é a Diretoria Regional de Educação (DRE). Não há menção à obrigatoriedade de as APMs discutirem ou apresentarem as prestações de contas ao Conselho de Escola, instância máxima de decisão nas escolas.

A Portaria 2810/2006 estabelece o Estatuto Padrão das APMs, no município de São Paulo. O Anexo Único da Portaria define:

Art. $2^{\circ}$ - A APM (completar com a denominação social da Unidade), respeitada a legislação vigente, se propõe:

I - auxiliar a unidade educacional a atingir seus objetivos educacionais, contribuindo para a construção do seu Projeto Pedagógico; 
II - representar as aspirações da comunidade e dos pais dos alunos, junto à unidade educacional;

III - constituir-se elo de ligação entre equipe escolar, família e, comunidade, contribuindo para:

a) o diálogo e a ação conjunta;

b) o diagnóstico e a solução de problemas relativos à inter-relação dos diversos grupos.

IV - mobilizar os recursos humanos, materiais e financeiros da Associação e aplicar verbas oriundas dos setores público ou privado, para auxiliar a unidade escolar, provendo condições que propiciem:

a) a melhoria do ensino;

b) o desenvolvimento de atividades assistenciais prestadas aos alunos;

c) a conservação e manutenção do prédio, dos equipamentos e das instalações;

d) a programação de atividades cívicas, culturais, desportivas, sociais, comunitárias e de lazer em que se empenhe a unidade educacional.

$\mathrm{V}$ - manter contatos com entidades pública ou privada, direta ou indiretamente relacionadas aos interesses da unidade educacional, recebendo, gerindo, aplicando e prestando contas dos recursos financeiros que lhe forem disponibilizados, observando a destinação apropriada e de acordo com a legislação em vigor.

VI - colaborar, no âmbito de sua competência, na promoção de alunos que se destacarem, pelas suas atuações, em atividades escolares, competições culturais, cívicas e desportivas.

VII - colaborar com as demais instituições auxiliares da unidade educacional no desenvolvimento de suas atividades.

VIII - firmar parcerias, convênios ou contratar a prestação de serviços determinados de empresas, com reserva antecipada e empenho do recurso do fundo financeiro próprio.

IX - divulgar, por todos os meios, os eventos da entidade e incentivar a participação da comunidade. (SÃO PAULO, 2006a)

Pelos itens estabelecidos como propósitos das APMs, percebe-se uma sobreposição aos estabelecidos como competência dos Conselhos de Escolas. Observa-se, também, que não há dispositivo que obrigue subordinação às decisões dos Conselhos de Escolas, que têm caráter deliberativo sobre algumas questões presentes para as atividades das APMs. A sobreposição de competências se acentua nos artigos 10 e 18 do Anexo Único:

Art. 10 - Compete à Diretoria Executiva:

I. elaborar o Plano Anual de Atividades e o Plano Orçamentário Anual, da Associação, bem como Plano de aplicação dos recursos externos disponibilizados, e relatório anual de atividades apresentando-os à Assembleia Geral, em reunião ordinária;

[...]

VI. abrir conta em instituição da Rede Bancária Nacional, em nome da Associação de Pais e Mestres, na qual deverão ser preservados os valores recebidos, devendo a referida conta ser movimentada, conjuntamente, pelo Presidente da Diretoria Executiva e pelo $1^{\circ}$ Tesoureiro;

VII. apresentar ao Conselho Fiscal, bimestralmente, o balancete e, anualmente, ao final do mandato, o balanço e o relatório anual das atividades da Associação, acompanhados das contas do exercício, inclusive.

[...]

Art. 18 - Compete ao Conselho Fiscal:

[...] 
III. elaborar, juntamente com a Diretoria Executiva, o Plano Anual de Atividades e o Plano Orçamentário Anual da Associação, bem como da aplicação de recursos externos disponibilizados, coordenado, conjuntamente, sua execução; [...]

VIII. acompanhar e fiscalizar a gestão financeira da Associação de Pais e Mestres; (SÃO PAULO, 2006a)

Novamente, não aparece nenhuma menção à competência que cabe aos Conselhos de Escola de decidir procedimentos relativos à priorização de aplicação de verbas (presente tanto no artigo 109, da Lei 11.229/1992, quanto no artigo 118 da Lei 14.660/2007). Cabe observar que essa ambiguidade já ocorreu no início da criação das APMs, em relação às Caixas Escolares (BUENO, 1987). 


\section{O PROGRAMA DE TRANSFERENCIA DE RECURSOS FINANCEIROS DA PMSP}

Neste capítulo, por meio da documentação que regulamenta e normatiza o PTRF, pretende-se analisar: a) o processo de aprovação da legislação que instituiu o programa; b) os procedimentos necessários para que as APMs das escolas recebam os recursos e também como prestam contas dos recursos financeiros transferidos; c) as possibilidades e proibições de uso desses recursos; d) a aplicação, no período de análise da pesquisa, no âmbito da SME; e) a divisão dos recursos financeiros, por categoria econômica, capital e custeio; f) a relação dos recursos financeiros do PTRF com outras formas de descentralização de recursos financeiros que as escolas da rede municipal recebem.

Assim, nesta parte do trabalho, são utilizados documentos oficiais, fontes primárias de arquivos públicos. Para Marconi e Lakatos: "Documentos oficiais constituem geralmente a fonte mais fidedigna de dados. Podem dizer respeito a atos individuais, ou, ao contrário, atos da vida política, de alcance municipal, estadual ou nacional.” (MARCONI; LAKATOS, 1996, p. 60-61)

As autoras alertam, porém, sobre algumas preocupações na utilização desse tipo de fonte: "O cuidado do pesquisador diz respeito ao fato de que não exerce controle sobre a forma como os documentos foram criados. Assim, deve não só selecionar o que lhe interessa, como também interpretar e comparar o material, para torná-lo utilizável” (MARCONI; LAKATOS, 1996, p. 61).

Nesse sentido, utiliza-se também como recurso metodológico entrevista com a presidente da Comissão Técnica do PTRF e os documentos orçamentários da Secretaria Municipal do Planejamento, Orçamento e Gestão (Sempla) para confrontar os documentos.

\subsection{Histórico e normatização da Lei}

Em 10 de junho de 2005, é promulgada, no Município de São Paulo, a Lei 13.991, que institui o PTRF às APMs das unidades educacionais da rede municipal de ensino de São 
Paulo. A lei não foi encaminhada pelo Poder Executivo, mas foi uma propositura do vereador Paulo Frange, filiado ao Partido Trabalhista Brasileiro (PTB).

O Projeto de Lei (PL), que viria a se tornar a Lei 13.991/2005, é encaminhado para discussão na Câmara Municipal de São Paulo em fevereiro de 2002, como PL 155/2002, no governo Marta Suplicy, do PT. Contudo, não é o primeiro PL para estabelecer repasse de recursos, por meio de convênio com as APMs das escolas. O mesmo vereador, em 2000, propõe o PL 119/2000, aprovado pelo plenário da Câmara, mas vetado na íntegra, pelo Executivo da época. Em 2001, o vereador Cláudio Fonseca (então filiado ao Partido Comunista do Brasil - PCdoB), também presidente do Sindicato dos Profissionais em Educação do Ensino Municipal de São Paulo (Sinpeem), apresenta o PL 47/2001, abordando a mesma questão. Ambos os PLs apresentam redação quase idênticas.

O PL 155/2002 tinha como objetivo instituir na SME o programa Gestão Participativa de Recursos da Escola Municipal, que consistia em "fortalecer a participação da comunidade no processo de construção da autonomia das escolas municipais", por meio de transferência de recursos para as APMs. Os montantes seriam estabelecidos pelo orçamento anual e utilizados exclusivamente em despesas de material de consumo, serviços e material permanente para atender o desenvolvimento de projetos pedagógicos específicos e manutenção e conservação dos prédios escolares (SÃO PAULO, 2002a).

A justificativa do PL fundamentou-se na LDB (Lei 9.394/96), que estabeleceu que as escolas deveriam alcançar progressivos graus de autonomia pedagógica, administrativa e de gestão financeira (art. 15). Sobre a LDB, considerou a justificativa do PL: "é uma Lei cujo espírito é, sobretudo, o da descentralização efetiva não só dos trabalhos mas também de recursos com intuito de ser garantida a qualidade de ensino" (SÃO PAULO, 2002a). Ainda abordou que "a descentralização de recursos, enquanto as unidades escolares não se tornarem unidades orçamentárias, somente é possível via convênio com as Associações de Pais e Mestres" (SÃO PAULO, 2002a).

Para que as unidades escolares tornem-se uma unidade orçamentária é necessário que passem por processo de descentralização autárquica, como ocorre no caso das universidades. Contudo, não é verdade que somente dessa forma é possível a descentralização de recursos. Há outras formas, como visto no capítulo 2. Inclusive, Polo (2001) tem uma minuta de proposta para que os municípios, se assim o desejarem, utilizem o adiantamento bancário para tal. Mas também não há impeditivos, por exemplo, de o Conselho de Escola se tornar pessoa 
jurídica e celebrar convênio com as secretarias de educação, como o município de Santo André $(2002 ; 2005)$.

A justificativa do PL reconheceu o Conselho de Escola como instância máxima "de elaboração, deliberação, acompanhamento e avaliação do planejamento e do funcionamento da unidade escolar" e lhe atribuiu tarefa de fiscalizar, com a SME, o cumprimento da lei (SÃO PAULO, 2002a).

Dentre as considerações da justificativa, o programa teria um caráter desburocratizante, pois

Com a compra do material escolar a cargo das Associações de Pais e Mestres, estes poderão fazer larga pesquisa no mercado, adquirindo daquele que oferecer o melhor preço e condições, afastando os riscos de licitações espúrias e impugnadas que só atrasam o processo de compra, sem benefícios para as crianças. (SÃO PAULO, 2002a)

A qualidade de ensino também é uma questão presente, e julgou-se que a descentralização de recursos financeiros pode contribuir para atingi-la. No texto da justificativa do PL, é atribuída à educação uma função de reparação ou amenização dos efeitos da estratificação social: "Este projeto de Lei tem como principal meta a viabilização da educação, visto a dificuldade progressiva da população mais carente de acompanhar o custo de vida, proporcionalmente aos aumentos legais de salários e o desemprego crescente." (SÃO PAULO, 2002a).

Em 29 de julho de 2002 é publicado o Parecer 888/2002 da Comissão de Constituição e Justiça sobre o PL 155/2002. Considerando a CF/88, a LDB/96, a Constituição do Estado de São Paulo e a Lei Orgânica do Município (LOM), a comissão vota pela legalidade e constitucionalidade contra um voto pela ilegalidade e inconstitucionalidade.

O voto contrário julgou que a matéria era de competência exclusiva do Executivo, assim ferindo a LOM, no seu artigo 37.

Art. 37 - A iniciativa das leis cabe a qualquer membro ou Comissão permanente da Câmara Municipal, ao Prefeito e aos cidadãos, na forma e nos casos previstos nesta Lei Orgânica.

[...]

$\S 2^{\circ}$ - São de iniciativa privativa do Prefeito as leis que disponham sobre:

[...]

IV - organização administrativa e matéria orçamentária; (SÃO PAULO, 1990) 
Avaliou também que o PL 0155/2002 imporia ao Executivo celebrar convênios, afetando, dessa forma, seu direito de decidir se quer realizar as compras ou transferi-las a outros. Tal medida também afetaria, segundo o relator, o que determina o seguinte artigo:

Art. 69 - Compete privativamente ao Prefeito, além de outras atribuições previstas nesta Lei:

$[\ldots]$

XVI - propor à Câmara Municipal projetos de leis sobre criação, alteração das Secretarias Municipais e Subprefeituras, inclusive sobre suas estruturas e atribuições. (SÃO PAULO, 1990)

Contudo, o Parecer apreciou que:

\begin{abstract}
A presente propositura não invade a competência privativa do Executivo, uma vez que não pode ser entendida como serviço público, porque, o que temos aqui é uma ação de utilidade pública, que deve o Município garantir através da celebração de convênios para repasse de recursos às APMs, destinados exclusivamente à cobertura de despesas com material de consumo, serviços e material permanente, necessários ao desenvolvimento de projetos pedagógicos e educacionais e não serviço público, tal como mencionam os artigos 196 a 198 da Constituição Federal. (SÃO PAULO, 2002b).
\end{abstract}

E apoiou-se também na própria LOM:

Art. 13 - Cabe à Câmara, com sanção do Prefeito, não exigida esta para o especificado no artigo 14, dispor sobre as matérias de competência do Município, especialmente:

$[\ldots]$

XV - dispor sobre convênios com entidades públicas, particulares e autorizar consórcios com outros municípios. (SÃO PAULO, 1990)

Em 11 de setembro de 2003, é publicado o Parecer 1220 da Comissão de Administração Pública sobre o então PL 0155/2002, expondo que a legislação da época não permitiria o repasse de verbas orçamentárias às APMs, mas era uma questão abrandada por conta do Programa Dinheiro Direto na Escola do governo federal usar esse mecanismo para repasse de recursos às escolas. Então, o Parecer foi favorável, mas sugeriu alteração na redação somente para facilitar o trâmite processual.

A Comissão de Educação, Cultura e Esportes se coloca favorável, por meio do Parecer 1539/2003, ao projeto com as adequações da redação sugeridas pela Comissão da Administração Pública. Não traz grandes considerações sobre a matéria, somente que o repasse de recursos está presente nas discussões da comunidade escolar e atende a LDB/96. 
Em 17 de maio de 2005, mais de três anos depois da proposição do PL 155/2002, é publicado o Parecer, sem número, da Comissão de Finanças e Orçamento. Este não proporciona objeções, mas traz uma proposta de substitutivo para adequar às regras de técnica legislativa previstas na Lei Complementar federal 95/1998.

Uma das sugestões de alteração foi sobre a denominação de Gestão Participativa de Recursos da Escola Municipal para Programa de Transferência de Recursos Financeiros. Foi também excluída qualquer menção aos Conselhos de Escola. Portanto, a relação se dá somente entre a APM e SME, o que pode significar uma fiscalização muito mais técnica e de, alguma maneira, não incentivando a participação da comunidade escolar. Essas questões podem ser sintomas de uma lógica de descentralização mais administrativa e menos política, ou seja, podem indicar um caráter mais técnico do que incentivo à participação da comunidade na construção da autonomia escolar.

Na sugestão de substitutivo da Comissão de Finanças Públicas e Orçamento, é incluída, para a elaboração do cálculo do repasse, a utilização dos dados oficiais do Censo Escolar do ano anterior e determinada a competência à prefeitura de regulamentar "a cada exercício financeiro, a forma de cálculo, o valor e a periodicidade das transferências, às UEx, bem como as orientações e instruções necessárias à execução do programa, observada a disponibilidade orçamentária". Há também um detalhamento maior sobre os usos dos recursos. (SÃO PAULO, 2005b).

Em 10 de junho de 2005, é aprovada a Lei 13.991, que institui o PTRF às APMs das unidades educacionais da rede municipal de ensino, cujo objetivo era "fortalecer a participação da comunidade escolar no processo de construção da autonomia das Unidades Educacionais da Rede Municipal de Ensino, em conformidade com o art. 15 da Lei no 9.394, de 20 de dezembro de 1996." (SÃO PAULO, 2005c). O texto da lei aprovada tem a mesma redação da sugestão de substitutivo da Comissão de Finanças Públicas e Orçamento.

Os usos dos recursos deveriam ser utilizados conforme a lei determina.

Art. $3^{\circ}$ - Os recursos transferidos ao Programa destinam-se à cobertura de despesas de custeio, manutenção dos equipamentos existentes, conservação das instalações físicas do sistema de ensino, e de pequenos investimentos, de forma a contribuir, supletivamente, para a garantia do funcionamento das unidades educacionais, devendo ser aplicados:

I - na aquisição de material permanente;

II - na aquisição de material de consumo necessário ao funcionamento da Unidade Educacional;

III - na manutenção, conservação e pequenos reparos da Unidade Educacional;

IV - no desenvolvimento de atividades educacionais;

$\mathrm{V}$ - na implementação de projetos pedagógicos da unidade educacional 
VI - na contratação de serviços.

$\S 1^{\mathrm{O}}$ - É vedada a aplicação dos recursos do Programa em gastos com pessoal do Quadro Geral do Pessoal da Prefeitura do Município de São Paulo ou contratado pelos órgãos públicos da Administração Direta ou Indireta.

$\S 2^{\underline{0}}$ - Não poderão ser realizadas obras, instalações elétricas e hidráulicas, e ainda reformas estruturais, de qualquer vulto, sem a prévia aprovação da área competente da Secretaria de Educação do Município de São Paulo.

$\S 3^{0}$ - Toda manutenção de prédio escolar deverá assegurar as características originais da edificação, no que se refere ao projeto arquitetônico, fachada e elementos estruturais, observadas as exigências da legislação vigente. (SÃO PAULO, 2005b; 2005c).

No que diz respeito ao uso dos recursos e suas finalidades, há uma questão importante sobre a aquisição de material permanente. Isso significa maior flexibilidade, em oposição aos processos de compras centralizados, por vezes lentos e que nem sempre atendem as especificidades de cada escola, permitindo às escolas um planejamento para aquisição de equipamentos, de acordo com as necessidades dos seus projetos pedagógicos.

Foi determinado pelo artigo $4^{\underline{0}}$ da Lei 13.991/2005 às APMs prestarem contas, conforme estabelecido pela LOM, e que cada nova parcela dos recursos somente seja liberada mediante prestação de contas da liberação anterior.

Houve veto do Executivo ao artigo $5^{\circ}$, que constava com a seguinte redação:

Art. 5ำ - A fiscalização da execução do Programa e da aplicação dos recursos financeiros é de competência da Secretaria Municipal de Educação que delegará aos órgãos competentes a realização de auditorias, inspeções e análise de processos de prestação de contas. (SÃO PAULO, 2005d)

A justificativa do veto esclarece que a pasta, no caso a SME, não pode delegar a competência de fiscalizar as contas, pois são de sua atribuição.

Posterior à aprovação da Lei 13.991/2005, sucedem-se algumas regulamentações e a elaboração de um manual intitulado Procedimentos para Aplicação dos Repasses Referentes ao Programa de Transferência de Recursos Financeiros - PTRF. Publicado em 2008, continha as orientações, passo a passo, dos procedimentos para firmar convênio entre APM e SME, as recomendações para a utilização e orientações para a prestação de contas.

No levantamento documental, obteve-se os atos legais relacionados no Quadro 2. 
Quadro 2 - Levantamento da regulamentação do PTRF

\begin{tabular}{|c|c|c|}
\hline Documento & Descrição / Ementa & Tema abordado \\
\hline $\begin{array}{l}\text { DECRETO } \\
46.230 \\
23 / 8 / 2005\end{array}$ & $\begin{array}{l}\text { Regulamenta a Lei } 13.991 \text {, de } 10 \text { de junho de } 2005 \text {, que institui o PTRF às APMs das unidades } \\
\text { educacionais da rede municipal de ensino. }\end{array}$ & $\begin{array}{l}\text { - } \\
\text { Uso dos recursos; } \\
\text { - } \quad \text { Temo de Compromisso; } \\
\text { Prestação de contas; e } \\
\text { Fiscalização. }\end{array}$ \\
\hline $\begin{array}{l}\text { PORTARIA SME } \\
6475 \\
4 / 10 / 2005\end{array}$ & $\begin{array}{l}\text { Estabelece os procedimentos para transferência e prestação de contas dos recursos destinados à } \\
\text { execução do PTRF, às APMs das unidades educacionais da rede municipal de ensino. }\end{array}$ & $\begin{array}{ll}\text { - } & \text { Procedimentos para a transferência dos recursos; } \\
\text { - } & \text { Periodicidade de liberação dos recursos; e } \\
\text { Atribuições e composição da Comissão } \\
\text { Específica de fiscalização da prestação de contas. }\end{array}$ \\
\hline $\begin{array}{c}\text { PORTARIA } \\
6686 / 2005-\text { SME }\end{array}$ & $\begin{array}{l}\text { Divulgar os valores a serem repassados às unidades educacionais à conta do PTRF, no corrente } \\
\text { exercício. }\end{array}$ & $\begin{array}{l}\text { Valores de repasse dos recursos; e } \\
\text { Período de realização das despesas. }\end{array}$ \\
\hline $\begin{array}{c}\text { PORTARIA } \\
6889 / 2005-\text { SME }\end{array}$ & Alterar o item 4 da Portaria 6.686, de 19 de outubro de 2005. & Utilização dos recursos \\
\hline $\begin{array}{c}\text { PORTARIA } \\
819 / 2006-\text { SME }\end{array}$ & Constitui Comissão Técnica referente à prestação de contas PTRF para as APMs. & Nomeação dos membros da Comissão Técnica \\
\hline $\begin{array}{c}\text { PORTARIA } \\
1845 / 2006-\text { SME }\end{array}$ & $\begin{array}{l}\text { Repasse de recursos às APMs das unidades educacionais - aplicação de 50\%, no mínimo, ao } \\
\text { desenvolvimento de atividades educacionais, conforme Lei 13991/2005. }\end{array}$ & Utilização dos recursos \\
\hline $\begin{array}{c}\text { PORTARIA } \\
2254 / 2006-\text { SME }\end{array}$ & Divulgar os valores do segundo, terceiro e quarto repasses. & $\begin{array}{l}\text { Valores de repasse dos recursos; e } \\
\text { Período de realização das despesas. }\end{array}$ \\
\hline $\begin{array}{c}\text { PORTARIA } \\
2990 / 2006-\text { SME }\end{array}$ & Constitui Comissão Técnica referente à prestação de contas do PTRF. & Nomeação dos membros da Comissão Técnica \\
\hline $\begin{array}{c}\text { PORTARIA } \\
2991 / 2006-\text { SME }\end{array}$ & Revogar, na íntegra, a Portaria SME 1.845, de 30/3/2006, que trata da aplicação das verbas do PTRF. & Utilização dos recursos \\
\hline
\end{tabular}




\begin{tabular}{|c|c|c|}
\hline Documento & Descrição / Ementa & Tema abordado \\
\hline $\begin{array}{l}\text { DECRETO } \\
47837 / 2006\end{array}$ & $\begin{array}{l}\text { Confere nova redação ao caput do artigo } 2^{-} \text {, do Decreto } 46230 \text {, de } 23 \text { de agosto de } 2005 \text {, que } \\
\text { regulamenta a Lei } 13991 \text {, de } 10 \text { de junho de } 2005 \text {, instituidora do PTRF às APMs das unidades } \\
\text { educacionais da rede municipal de ensino. }\end{array}$ & Utilização dos recursos \\
\hline $\begin{array}{c}\text { PORTARIA } \\
4351 / 2006-\text { SME }\end{array}$ & Altera o item 4 da Portaria SME 2.254, de 10/5/2006. & Utilização dos recursos \\
\hline \begin{tabular}{c|} 
PORTARIA \\
$7 / 2007-$ \\
Sutem/SF
\end{tabular} & $\begin{array}{l}\text { Divulgar a criação de itens de despesa para utilização orçamentária da Administração direta/indireta e } \\
\text { fundações. }\end{array}$ & Orçamento municipal \\
\hline $\begin{array}{c}\text { PORTARIA } \\
1876 / 2007-\text { SME }\end{array}$ & $\begin{array}{l}\text { Divulgar os valores do primeiro repasse às APMs das unidades educacionais, à conta do PTRF, do } \\
\text { corrente exercício de } 2007 \text {. }\end{array}$ & $\begin{array}{l}\text { - } \quad \text { Valores de repasse dos recursos; e } \\
\text { Período de realização das despesas. }\end{array}$ \\
\hline \begin{tabular}{c|} 
PORTARIA \\
$3615 / 2007-$ SME
\end{tabular} & $\begin{array}{l}\text { Divulgar os valores relativos ao segundo e terceiro repasse às APMs das unidades educacionais, do } \\
\text { PTRF, do corrente exercício. }\end{array}$ & $\begin{array}{l}\text { Valores de repasse dos recursos; e } \\
\text { Período de realização das despesas. }\end{array}$ \\
\hline $\begin{array}{l}\text { PORTARIA } \\
3887 / 2007\end{array}$ & Constitui Comissão Técnica, referente à prestação de contas do PTRF das APMs. & Nomeação dos membros da Comissão Técnica \\
\hline $\begin{array}{c}\text { PORTARIA } \\
4450 / 2007-\text { SME }\end{array}$ & $\begin{array}{l}\text { Substitui quadros anexos a p 6475/2005 utilizados para prestação de contas recursos destinados às } \\
\text { APMs das unidades educacionais. }\end{array}$ & Procedimentos para a transferência dos recursos \\
\hline $\begin{array}{l}\text { PORTARIA } \\
5678 / 2007\end{array}$ & $\begin{array}{l}\text { Critérios para repasse de recursos adicionais quando atingidas as metas de redução de água/energia } \\
\text { pelas unidades educacionais. }\end{array}$ & $\begin{array}{l}\text { Repasse de recursos adicionais; e } \\
\text { Critérios específicos para esse repasse. }\end{array}$ \\
\hline $\begin{array}{c}\text { PORTARIA } \\
1505 / 2008-\text { SME }\end{array}$ & Divulga os valores dos repasses às APMs das unidades educacionais, à conta do PTRF, para 2008. & $\begin{array}{l}\text { - } \quad \text { Valores de repasse dos recursos; } \\
\text { - } \quad \text { Período de realização das despesas; e } \\
\text { custeio e a capital. }\end{array}$ \\
\hline $\begin{array}{c}\text { PORTARIA } \\
4554 / 2008-\text { SME }\end{array}$ & $\begin{array}{l}\text { Estabelece procedimentos para transferência e prestação de contas dos recursos destinados à execução } \\
\text { do PTRF, às APMs das unidades educacionais da rede municipal de ensino, e divulga quadros para a } \\
\text { execução do PTRF. }\end{array}$ & $\begin{array}{l}\text { Procedimentos para a transferência dos recursos; } \\
\text { - } \quad \text { Periodicidade de liberação dos recursos; e } \\
\text { Específica de fiscalização da prestação de contas. }\end{array}$ \\
\hline
\end{tabular}




\begin{tabular}{|c|c|c|}
\hline Documento & Descrição / Ementa & Tema abordado \\
\hline $\begin{array}{c}\text { PORTARIA } \\
4721 / 2008-\text { SME }\end{array}$ & $\begin{array}{l}\text { Divulga o repasse de recursos adicionais às unidades educacionais da rede municipal de ensino que } \\
\text { atingiram as metas resultantes da redução do consumo de água e energia elétrica. }\end{array}$ & $\begin{array}{l}\text { Valor do repasse de recursos adicionais; } \\
\text { Uso dos recursos adicionais; e } \\
\text { Procedimentos para prestação de contas. }\end{array}$ \\
\hline $\begin{array}{c}\text { PORTARIA } \\
1758 / 2009-\text { SME }\end{array}$ & $\begin{array}{l}\text { Divulga valores do PTRF às APMs, das unidades educacionais da rede municipal de ensino para o } \\
\text { ano de } 2009 .\end{array}$ & $\begin{array}{l}\text { Valores de repasse dos recursos; } \\
\text { - } \quad \text { Período de realização das despesas; e } \\
\text { custeio e a capital. }\end{array}$ \\
\hline $\begin{array}{c}\text { PORTARIA } \\
2251 / 2009-\text { SME }\end{array}$ & $\begin{array}{l}\text { Estabelece a inclusão das APMs das unidades educacionais da rede municipal de ensino, recém- } \\
\text { criadas no PTRF. }\end{array}$ & $\begin{array}{l}\text { Repasse de recursos para escolas recém-criadas; } \\
\text { - } \quad \text { Critério específico para essas escolas no cálculo } \\
\text { do valor. }\end{array}$ \\
\hline $\begin{array}{c}\text { PORTARIA } \\
4023 / 2009-\text { SME }\end{array}$ & Constitui Comissão Técnica referente à prestação de contas do PTRF das APMS. & Nomeação dos membros da Comissão Técnica \\
\hline $\begin{array}{c}\text { PORTARIA } \\
2001 / 2010-\text { SME }\end{array}$ & $\begin{array}{l}\text { Divulga valores do PTRF às APMS das unidades educacionais da rede municipal de ensino para o ano } \\
\text { de } 2010 \text {. }\end{array}$ & $\begin{array}{l}\text { Valores de repasse dos recursos; } \\
\text { - } \quad \text { Período de realização das despesas; e } \\
\text { custeio e a capital. }\end{array}$ \\
\hline $\begin{array}{c}\text { PORTARIA } \\
3664 / 2010-\text { SME }\end{array}$ & $\begin{array}{l}\text { Divulga valores do PTRF às Associação de Pais, Mestres, Servidores, Usuários e Amigos dos Centros } \\
\text { Educacionais Unificados (APMSUACS) para } 2010 .\end{array}$ & $\begin{array}{l}\text { Inclusão da APMSUACS no PTRF; } \\
\text { Valores de repasse dos recursos; e } \\
\text { Divisão das despesas em percentual referente a } \\
\text { custeio e a capital. }\end{array}$ \\
\hline
\end{tabular}


A pesquisa levantou 25 atos legais, entre portarias e decretos posteriores à aprovação da lei que instituiu o PTRF até o ano de 2010. Em sua maioria, os documentos tratavam dos Termos de Compromisso a serem firmados entre as APMs e a SME, dos usos dos recursos, da prestação de contas, da fiscalização e dos cálculos e valores a serem transferidos para as APMs. As normas estabelecidas pela legislação serão analisadas no decorrer dos itens subsequentes.

\subsection{Procedimentos para recebimento dos recursos e prestação de contas}

O Decreto 46.230, de 23 de agosto de 2005, regulamenta a Lei 13.991/2005, determinando que a transferência de recursos oriundos do PRTF seja feita por meio de Termo de Compromisso assinado entre a Coordenadoria de Educação ${ }^{13}$, em nome da SME, e a APM da unidade educacional.

O Termo tinha como objetivo formalizar as obrigações de prestação de contas, do uso dos recursos dentro das finalidades determinadas na lei, e as formas de fiscalização presentes no próprio Decreto 46.230/2005. Contudo, é interessante notar que a Cláusula Terceira estabelece que o prazo de validade do Termo de Compromisso seja igual ao do mandato dos membros da APM, ou seja, de um ano; mas, quando o presidente for o diretor da escola, o Termo será valido enquanto o diretor ocupar o cargo na unidade escolar. Quanto a essa cláusula, pode-se observar certo estímulo a que a presidência da APM seja ocupada pelo diretor, evitando, assim, mais um processo administrativo.

A Portaria 4554/2008, que estabelece os procedimentos para transferência e prestação de contas dos recursos destinados à execução do PTRF, determina em seu Anexo I que as APMs deveriam apresentar, para fim de cadastro, às Diretorias Regionais de Educação (DRE), os seguintes documentos:

\footnotetext{
13 A partir da Lei 14.660/2007, a Coordenadoria de Educação passa a se chamar Diretoria Regional de Educação (DRE).
} 
a) Ofício de encaminhamento da APM à DRE, solicitando o cadastro;

b) Ficha Cadastro da APM e do Presidente da Diretoria Executiva;

c) Cópia do cartão atualizado do Cadastro Nacional de Pessoa Jurídica (CNPJ) da APM;

d) Cópia, registrada em cartório, do Estatuto da APM;

e) Cópia, registrada em cartório, da Ata da Assembleia Geral que elegeu a Diretoria

Executiva e o Conselho Fiscal;

f) Cópia do CPF e RG do Presidente da Diretoria Executiva da APM;

g) Cópia do recibo de entrega da:

- Declaração de Isenção de Imposto de Renda Pessoa Jurídica (DIPJ);

- Relação Anual de Informações Sociais (Rais) negativa;

- Declaração de Débitos e Créditos Tributários Federais (DCTF);

- Declaração do Imposto Retido na Fonte (Dirf);

- Guia de Recolhimento do Fundo de Garantia por Tempo de Serviço e Informações à Previdência Social (GFIP);

h) Cópia do comprovante de pagamento da Taxa de Fiscalização do Estabelecimento (TFE). (SÃO PAULO, 2008a)

Na Portaria 6475/2005, a SME também exige uma série de documentos necessários como parte dos procedimentos de transferência dos recursos. Eram os mesmos da Portaria 4554/2008 dos itens “a” ao "f", e somente a DIPJ e a Rais negativa do item "g”.

A documentação deveria ser atualizada sempre que necessário, por determinação legal ou alteração da situação da APM. Não havendo a regulamentação da documentação, os repasses dos recursos seriam suspensos.

Segundo a Portaria 4554/2008, após a apresentação dos documentos exigidos (acima descritos), deveria ocorrer o processamento da nota de empenho ${ }^{14}$ e a autorização do titular da unidade orçamentária. Somente então, o Termo de Compromisso seria encaminhado para assinatura do diretor da DRE, do presidente da diretoria executiva da APM, de um membro do conselho fiscal, de um representante da unidade educacional e de duas testemunhas. $\mathrm{Na}$ primeira liberação dos recursos era necessário requerimento de solicitação de pagamento. Se não for o primeiro repasse, com a aprovação da prestação de contas, a DRE processaria a nota de liquidação ${ }^{15}$ e pagamento.

Os recursos provindos do PTRF seriam repassados para conta bancária específica em instituição financeira definida pela PMSP e discriminada no Termo de Compromisso. Se não

\footnotetext{
14 Nota de empenho é o documento emitido em nome do favorecido que atesta o registro no sistema de contabilidade da despesa a ser realizada e deduzida do saldo da dotação orçamentária própria.

15 Nota de liquidação é o documento que atesta a verificação formal das exigências (entrega dos bens, realização dos serviços ou atendimento das condições no termo de concessão ou contrato para o convênio, no caso específico) para realização das despesas.
} 
houvesse previsão de utilização dos recursos transferidos no período de um mês, estes deveriam ser aplicados em caderneta de poupança, e os recursos gerados da aplicação financeira deveriam ser, obrigatoriamente, considerados como receitas do PTRF na dotação de custeio.

A Portaria 4554/2008, em seu Anexo I, estabelece que a prestação de contas a ser encaminhada para a DRE pela APM deve obedecer aos seguintes itens:

a) Ofício de encaminhamento da prestação de contas à Diretoria Regional de Educação com as justificativas cabíveis;

b) Demonstrativo da Execução da Receita e da Despesa e de Pagamentos Efetuados [...];

c) Relação de Bens Adquiridos ou Produzidos [...], quando houver;

d) Demonstrativo da Conciliação Bancária [...], quando necessário;

e) Termo de Doação [...], quando houver;

f) Extrato da conta bancária em que os recursos foram depositados, evidenciando a movimentação de todos os cheques emitidos;

g) Cópia da Ata de reunião da Associação de Pais e Mestres contendo o Plano de Aplicação dos Recursos transferidos à conta do PTRF, onde serão pormenorizados os critérios de gastos, de acordo com os princípios desta Portaria;

h) Cópia do Parecer do Conselho Fiscal da Associação de Pais e Mestres sobre a regularidade das contas e dos respectivos documentos comprobatórios, com a aprovação lavrada em Ata. (SÃO PAULO, 2008a)

Observa-se que na prestação de contas há a necessidade de apresentação da Ata de Reunião da APM, contendo o Plano de Aplicação dos Recursos do PTRF e a aprovação do Conselho Fiscal, o que revela certa preocupação de discussão sobre o uso dos recursos e seus critérios. No entanto, essa exigência não estabelece uma cobrança clara de que a discussão também se realize no Conselho de Escola. Mesmo não sendo um empecilho que as unidades educacionais adotem a prática de fazer essa discussão no Conselho de Escola, causa, no mínimo, estranhamento o fato de a APM não ser obrigada a apresentar a prestação de contas ao órgão máximo de deliberação da unidade educacional.

A Portaria estabelece que o prazo para a prestação de contas seja de até cinco dias após o encerramento do período de utilização dos recursos. Mas se a documentação não fosse enviada ou aprovada, a DRE estabeleceria o prazo máximo de dez dias para regularização. No caso da não regularização, prevê a tomada de contas especial. Determina também que os originais deveriam ser guardados por dez anos na unidade educacional, a partir da aprovação de contas, e que estivessem à disposição da DRE, da SME e de órgãos de controle interno e 
externos para eventuais auditorias. A cada exercício financeiro, a SME realizaria auditoria por sistema de amostragem, inclusive com inspeção nas unidades educacionais.

As DREs deviam prestar contas à SME, e em caso do não cumprimento a SME suspenderia o repasse de recursos a todas as unidades educacionais, que estivessem sob a responsabilidade da DRE com a prestação de contas pendente.

Referente ao controle dos gastos, o Decreto 46.230/2005 estabelece também que:

Art. $5^{\mathrm{O}}$ - A fiscalização da aplicação dos recursos financeiros relativos ao Programa de que trata este decreto será exercida pela Secretaria Municipal de Educação, por meio das Coordenadorias de Educação e respectivos órgãos competentes, mediante verificação que ateste a utilização dos recursos exclusivamente aos fins admitidos, auditoria, inspeção in loco e análise dos processos que originaram as respectivas prestações de contas.

$\S 1^{\circ}$. A verificação das contas será realizada por comissão específica constituída pelas Coordenadorias de Educação, da Secretaria Municipal de Educação. (SÃO PAULO, 2005a).

Tanto a Portaria 6475/2005 quanto a Portaria 4554/2008 determinam que as comissões específicas fossem compostas por, no mínimo, três membros, com um dos servidores obrigatoriamente tendo formação em ciências contábeis e com registro no Conselho Regional de Contabilidade. É designado como função da comissão específica emitir parecer técnico conclusivo sobre as prestações de contas e encaminhá-las ao Diretor da DRE para apreciação e deliberação.

A SME cria, também, por meio da Portaria 819/2006, a Comissão Técnica para orientar as equipes das DREs a receber, analisar, orientar e auditar as prestações de contas. As Portarias 2990/2006, 3887/2007 e 4023/2009 apenas alteraram a composição da Comissão Técnica.

\subsection{Uso dos recursos}

Além de se observar os procedimentos para o recebimento dos recursos do PTRF e as obrigações às quais as APMs estão submetidas, é importante analisar a que essa 
descentralização de recursos se destina, ou melhor, em que os recursos financeiros podem ser gastos.

A Lei 13.991/2005 determina que os gastos oriundos dos repasses do PTRF sejam utilizados para:

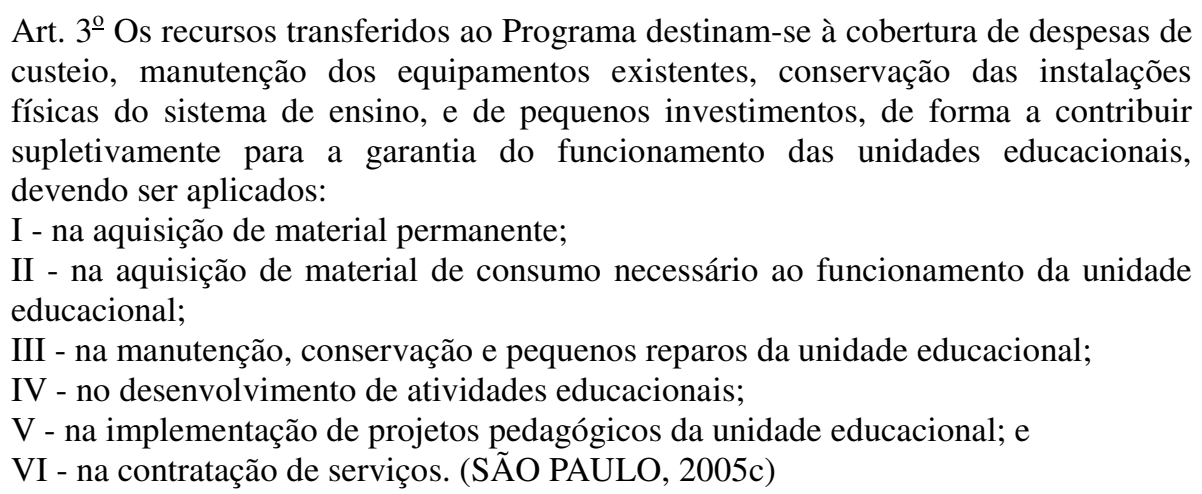

A Lei Federal 4.320, de 17 de março de 1964, que institui as normas gerais de direito financeiro para elaboração e controle dos orçamentos e balanços da União, dos estados, dos municípios e do Distrito Federal, em seu artigo 12, define que as despesas sejam classificadas em duas categorias econômicas: despesas correntes (despesas de custeio e transferências correntes) e despesas de capital (investimentos, inversões financeiras e transferências de capital). A definição presente na lei do PTRF permitia a realização de gastos nas duas categorias econômicas, mais especificamente em despesas de custeio e investimentos. $\mathrm{O}$ artigo 12, da Lei 4.320/1964 conceitua que:

Art. $12[\ldots]$

$\S 1^{\underline{0}}$ Classificam-se como Despesas de Custeio as dotações para manutenção de serviços anteriormente criados, inclusive as destinadas a atender a obras de conservação e adaptação de bens imóveis.

[...]

$\S 4^{0}$ Classificam-se como investimentos as dotações para o planejamento e a execução de obras, inclusive as destinadas à aquisição de imóveis considerados necessários à realização destas últimas, bem como para os programas especiais de trabalho, aquisição de instalações, equipamentos e material permanente e constituição ou aumento do capital de empresas que não sejam de caráter comercial ou financeiro. (BRASIL, 1964.)

Contudo, o Decreto 46.230 de 23 de agosto de 2005, que regulamenta a lei do PTRF, em seu artigo $2^{\circ}$, diz: 


\begin{abstract}
Art. $2^{\underline{o}}$ - Os recursos transferidos, à conta do PTRF, serão destinados apenas à cobertura das despesas de custeio enumeradas nos incisos I a VI do artigo $3^{\circ}$ da Lei $\mathrm{n}^{\mathrm{o}}$ 13.991, de 2005, observando-se as seguintes disposições:

I - a aquisição de bens, bem como a contratação de serviços para o desempenho das atividades e pleno funcionamento da unidade educacional da rede municipal de ensino serão realizadas em conformidade com as normas que regem licitações e contratos da Administração Pública, notadamente com a Lei Federal nº 8.666, de 21 de junho de 1993, a Lei n⿳⺈ 13.278 , de 7 de janeiro de 2002, e com os respectivos decretos regulamentares; [...] (SÃO PAULO, 2005a)
\end{abstract}

No artigo $2^{-}$do Decreto há uma clara contradição, pois ao afirmar que os recursos deveriam ser utilizados "apenas à cobertura de despesas de custeio" significa que não se poderia aplicar os recursos no item I do mesmo artigo, como prevê o item I do artigo $3^{\underline{0}}$ da Lei $13.991 / 2005$.

Posteriormente ao Decreto 46.230/2005, a Portaria 6475/2005 prevê que os recursos seriam utilizados em "aquisição de material de consumo e permanente". O item 15 dessa Portaria também revela a preocupação com o controle das despesas de capital:

15. Os bens patrimoniais adquiridos ou produzidos com recursos transferidos à conta do PTRF deverão ser incorporados ao patrimônio da Prefeitura Municipal e destinados ao uso dos respectivos estabelecimentos de ensino beneficiados, cabendo-lhes a responsabilidade pela guarda e conservação dos bens. (SÃO PAULO, 2005a)

Talvez a limitação no Decreto 46.230/2005 tenha sido apenas um problema de redação, haja vista que em 31 de outubro de 2006 é editado o Decreto 47.837/2006, unicamente para corrigir a limitação dos gastos com custeios. Contudo, o fato de o orçamento de 2006 ter previsto apenas recursos para "Outros Serviços de Terceiros - Pessoa Jurídica" e R\$ 0,00 para "Equipamentos e Material Permanente" não impediu que valores fossem liquidados nessa despesa.

Outro indício de que a questão sobre os gastos do PTRF em despesas de capital é complexa, está presente na Portaria da Sutem/SF 7/2007, que cria novo item de despesa para o PTRF para aquisição de materiais permanentes.

É previsto na Portaria 4554/2008 que os recursos do PTRF poderiam ser gastos com serviços contábeis, reativação do Cadastro do Contribuinte Mobiliário (CCM) e taxas destinadas à manutenção da regularidade das APMs. Por um lado, essa possibilidade de gasto 
garante que as APMs não voltem seus esforços para a arrecadação de recursos para sua manutenção e regularidade, por outro lado, constitui-se como uma parcela dos recursos que não pode ficar de fora das prioridades dos gastos.

A Portaria 1845, de 30 de março de 2006, determina que, no mínimo, 50\% dos recursos do PTRF deveriam ser utilizados no "desenvolvimento de atividades educacionais e na implementação de projetos pedagógicos da Unidade Educacional” (SÃO PAULO, 2006b). Entretanto, é revogada pela Portaria 2991, de 28 de junho de 2006. Em entrevista ${ }^{16}$, Sônia Regina Amaral Caldas Medeiros, presidente da Comissão Técnica, cujo objetivo é orientar, receber, analisar e auditar as prestações de contas das DREs, ao ser questionada sobre a revogação da vinculação de, no mínimo, 50\%, responde que a revogação da Portaria é feita por solicitação das próprias escolas, sob a justificativa que tal medida "engessava" a aplicação dos recursos financeiros descentralizados.

Sobre a justificativa cabem alguns questionamentos: "engessa" por que não possibilita que as escolas decidam em que utilizar? Ou "engessa" por que os recursos são utilizados em despesas de outra ordem que não as pedagógicas?

A DRE Butantã da SME de São Paulo produziu uma lista de serviços, materiais de consumo e bens permanentes que podem ser utilizados ou adquiridos com os recursos do PTRF; embora todos os itens listados sejam necessários ao andamento das atividades das escolas, boa parte deles não tem direta ligação às atividades pedagógicas. Muitos deles são imprescindíveis ao funcionamento de todas as escolas, como limpeza da caixa d'água, carga de extintores e limpeza de fossas, mas não são gastos com o pedagógico. Então, como as escolas terão condições de decidir se os recursos cobrem necessidades imprescindíveis e predeterminadas a todas as unidades educacionais?

Viu-se, até aqui, como podem ser utilizados os recursos do PTRF, então, é interessante observar suas limitações e proibições. No texto da Lei 13.991/2005, em seu artigo $3^{0}$ diz:

$\S 1^{\mathrm{o}}$ É vedada a aplicação dos recursos do Programa em gastos com pessoal do Quadro Geral do Pessoal da Prefeitura do Município de São Paulo ou contratado pelos órgãos públicos da Administração Direta ou Indireta.

\footnotetext{
${ }^{16}$ Entrevista realizada em 15/12/2010, em conjunto com o Projeto de Pesquisa Gestão Financeira Escolar como Política Pública: análise de procedimentos legais e administrativos, processos participativos e montantes dos recursos financeiros destinados às escolas de redes públicas, sob a coordenação do Prof. Dr. Rubens Barbosa de Camargo.
} 
$\S 2^{\underline{0}}$ Não poderão ser realizadas obras, instalações elétricas e hidráulicas, e ainda reformas estruturais, de qualquer vulto, sem a prévia aprovação da área competente da Secretaria de Educação do Município de São Paulo.

$\S 3^{0}$ Toda manutenção de prédio escolar deverá assegurar as características originais da edificação, no que se refere ao projeto arquitetônico, fachada e elementos estruturais, observadas as exigências da legislação vigente. (SÃO PAULO, 2005c)

As limitações postas nos parágrafos $2^{0}$ e $3^{0}$ têm clara preocupação com a manutenção dos projetos arquitetônicos originais das escolas. Contudo, cabe ressaltar que muitas das escolas da rede municipal de ensino, por ação da própria SME, passaram por reformas de ampliação dos espaços, os chamados anexos, ou popularmente chamados "puxadinhos", para atender a demanda. Em decorrência dessas alterações, não são poucos os problemas e inadequações dos espaços, pois, em sua maioria, as ampliações visavam aumentar o número de salas de aulas, por vezes, ignorando a necessidade de adequação de espaços comuns, como refeitório, banheiros, laboratórios, entre outros.

No parágrafo $1^{\underline{0}}$, percebe-se a preocupação em não duplicar o pagamento para o quadro do pessoal. Exigência que está em consonância com o princípio da separação da esfera pública e da esfera privada, o combate ao clientelismo e à extração de vantagens pessoais do Estado.

Sendo o propósito do PTRF, garantir o funcionamento das unidades de ensino, e podendo os recursos serem utilizados para o desenvolvimento de atividades educacionais, a implementação de projetos pedagógicos da unidade educacional e a contratação de serviços, os recursos do PTRF poderiam ser utilizados para assessoria pedagógica aos professores?

Em entrevista, a presidente da Comissão Técnica, Sônia Medeiros, afirma que os recursos não podem ser utilizados para tais serviços, pois a SME possui setor responsável pela formação. Contudo, há limitações dos setores responsáveis em atenderem às necessidades das escolas, em especial nas especificidades de seus projetos próprios. Para atender uma rede como a municipal de ensino de São Paulo, seria necessário um quadro muito grande de profissionais (que a rede não possui) para assessorar as escolas em seus projetos. Isso pode indicar que as formações e assessorias que a rede oferece têm como característica uma ação mais geral e uniforme. Dessa forma, a autonomia das escolas pode significar uma dificuldade, na medida em que não devem buscar, fora da SME, instituições ou especialistas para auxiliálas nos seus projetos. 


\subsection{Aplicação dos recursos do programa}

Estudos sobre políticas educacionais e gestão escolar consideram que a progressiva autonomia pedagógica, administrativa e de gestão financeira, princípio presente na LDB/96, pode apresentar ambiguidades e armadilhas (PARO, 2002; PERONI, 2006).

Deve-se analisar, se as políticas de descentralização, no bojo da reestruturação do papel do Estado, propagadas a partir da década 1990, não significam desresponsabilização das obrigações estatais.

Para verificar isso, um dos primeiros aspectos a ser observado deve ser o montante de recursos destinados ao programa, ou seja quanto do orçamento da educação é utilizado para viabilizar tal política. A Tabela 1 registra os valores utilizados no período de 2006 a 2010 no PTRF.

Tabela 1 - Gastos do PTRF por ano (em R\$)

\begin{tabular}{l|rrrrr}
\hline Ano & $\mathbf{2 0 0 6}$ & $\mathbf{2 0 0 7}$ & $\mathbf{2 0 0 8}$ & $\mathbf{2 0 0 9}$ & $\mathbf{2 0 1 0}$ \\
\hline Total nominal & 36.785 .864 & 39.779 .311 & 41.799 .599 & 41.719 .275 & 46.532 .847 \\
Total deflacionados & 45.939 .684 & 47.406 .672 & 46.467 .109 & 44.523 .111 & 46.532 .847 \\
\hline
\end{tabular}

Fonte: Elaborada pelo autor, com base nos dados da Sempla. Valores deflacionados para 12/2010, pelo Índice Nacional de Preços ao Consumidos (INPC), medido pelo Instituto Brasileiro de Geografia e Estatísticas (IBGE).

A partir de 2006, os gastos no PTRF mantiveram movimento crescente, se considerarmos os valores nominais, menos em 2009. Contudo, ao observarem-se os valores corrigidos para dezembro de 2010, nota-se que no ano de 2007 destinaram-se mais recursos para o programa, cerca de $\mathrm{R} \$ 47$ milhões. Em 2009, os recursos aplicados foram menores que os praticados em 2006.

No ano de 2005, conforme a Portaria 6686, publicada em 19 de outubro de 2005, as APMs que se registrassem até o dia 28 de outubro de 2005 receberiam repasse, e as despesas deveriam ser realizadas até o dia 31 de dezembro de 2005. No Quadro Detalhado da Despesa da Execução Orçamentária 2005, não consta registro de despesas pelo PTRF, pois a criação do programa é posterior a LOA. 
Observado o volume de despesas realizadas pelo PTRF, torna-se indispensável compreender o quanto esses valores representam no orçamento da educação.

A CF/88 determina que os municípios nunca destinem montante inferior a $25 \%$ das receitas de impostos e transferências para a manutenção e desenvolvimento do ensino (MDE). As despesas em MDE são regulamentadas pela LDB/96, em seu artigo 70, bem como o que não pode ser considerado como despesas de MDE consta no artigo 71.

Art. 70. Considerar-se-ão como de manutenção e desenvolvimento do ensino as despesas realizadas com vistas à consecução dos objetivos básicos das instituições educacionais de todos os níveis, compreendendo as que se destinam a:

I - remuneração e aperfeiçoamento do pessoal docente e demais profissionais da educação;

II - aquisição, manutenção, construção e conservação de instalações e equipamentos necessários ao ensino;

III - uso e manutenção de bens e serviços vinculados ao ensino;

IV - levantamentos estatísticos, estudos e pesquisas visando precipuamente ao aprimoramento da qualidade e à expansão do ensino;

$\mathrm{V}$ - realização de atividades-meio necessárias ao funcionamento dos sistemas de ensino;

VI - concessão de bolsas de estudo a alunos de escolas públicas e privadas;

VII - amortização e custeio de operações de crédito destinadas a atender ao disposto nos incisos deste artigo;

VIII - aquisição de material didático-escolar e manutenção de programas de transporte escolar.

Art. 71. Não constituirão despesas de manutenção e desenvolvimento do ensino aquelas realizadas com:

I - pesquisa, quando não vinculada às instituições de ensino, ou, quando efetivada fora dos sistemas de ensino, que não vise, precipuamente, ao aprimoramento de sua qualidade ou à sua expansão;

II - subvenção a instituições públicas ou privadas de caráter assistencial, desportivo ou cultural;

III - formação de quadros especiais para a administração pública, sejam militares ou civis, inclusive diplomáticos;

IV - programas suplementares de alimentação, assistência médico-odontológica, farmacêutica e psicológica, e outras formas de assistência social;

V - obras de infraestrutura, ainda que realizadas para beneficiar direta ou indiretamente a rede escolar;

VI - pessoal docente e demais trabalhadores da educação, quando em desvio de função ou em atividade alheia à manutenção e desenvolvimento do ensino. (BRASIL, 1996)

A LOM de São Paulo em 1990 previa, no mínimo, 30\%, percentual superior ao determinado pela CF/88, para MDE. Mas, em 2001, com a aprovação da Emenda 24, a vinculação de receitas da LOM passa para $31 \%$.

Art. 208 - O Município aplicará, anualmente, no mínimo $31 \%$ (trinta e um por cento) da receita resultante de impostos, compreendida a proveniente de 
transferências, na manutenção e desenvolvimento do ensino fundamental, da educação infantil e inclusiva. (SÃO PAULO, 1990, grifo nosso)

Contudo, os 31\% não são destinados exclusivamente para MDE. A Emenda 24/2001 acrescenta a expressão "educação inclusiva" e a define.

\begin{abstract}
Art. 203 - É dever do Município garantir:
[...]

IV - educação inclusiva que garanta as pré-condições de aprendizagem e acesso aos serviços educacionais, a reinserção no processo de ensino de crianças e jovens em risco social, o analfabetismo digital, a educação profissionalizante e a provisão de condições para que o processo educativo utilize meios de difusão, educação e comunicação; (SÃ̃ PAULO, 1990)
\end{abstract}

Entre os gastos da educação inclusiva estão uniformes que a prefeitura fornece a todas as crianças matriculadas, material para as crianças e merenda escolar.

Art. 200 - A educação ministrada com base nos princípios estabelecidos na Constituição da República, na Constituição Estadual e nesta Lei Orgânica, e inspirada nos sentimentos de igualdade, liberdade e solidariedade, será responsabilidade do Município de São Paulo, que a organizará como sistema destinado à universalização do ensino fundamental e da educação infantil.

[...]

$\S 4^{\underline{o}}$ - O Plano Municipal de Educação atenderá ao disposto na Lei Federal $\mathrm{n}^{\mathrm{o}}$ 9.394/96 e será complementado por um programa de educação inclusiva cujo custeio utilizará recursos que excedam ao mínimo estabelecido no artigo $212, \S 4^{\circ}$, da Constituição Federal. (SÃO PAULO, 1990)

Observado o disposto na LOM de São Paulo, a Tabela 2 identifica a representação do PTRF nas despesas da educação.

Tabela 2 - Relação do PTRF com as despesas em educação, por ano (em R\$ e \%).

\begin{tabular}{|c|c|c|c|c|c|}
\hline Ano & $\begin{array}{l}\text { MDE-25\% } \\
\text { (R\$) }\end{array}$ & $\begin{array}{l}\text { MDE e Ed. } \\
\text { Inclusiva } \quad(\mathbf{R} \$)\end{array}$ & $\begin{array}{l}\text { PTRF } \\
\text { (R\$) }\end{array}$ & $\begin{array}{c}\text { PTRF/MDE } \\
\text { (\%) }\end{array}$ & $\begin{array}{c}\text { PTRF/MDE e Ed. } \\
\text { Inclusiva } \\
(\%) \\
\end{array}$ \\
\hline 2006 & 4.944 .940 .470 & 5.689 .641 .361 & 45.939 .684 & 0,93 & 0,81 \\
\hline 2007 & 5.297 .747 .464 & 6.305.722.685 & 47.406 .672 & 0,89 & 0,75 \\
\hline 2008 & 5.929 .658 .964 & 6.836 .708 .145 & 46.467 .109 & 0,78 & 0,68 \\
\hline 2009 & 5.959 .308 .267 & 6.681 .117 .242 & 44.523.111 & 0,75 & 0,67 \\
\hline 2010 & 6.243 .545 .983 & 7.121.867.731 & 46.532 .847 & 0,75 & 0,65 \\
\hline
\end{tabular}

Fonte: Elaborada pelo autor, com base nos dados da Sempla. Valores deflacionados para 12/2010, pelo INPC (IBGE). 
Conforme se pode observar na Tabela 2, os recursos destinados ao PTRF não chegam a $1 \%$ do total das despesas com educação, mesmo comparando apenas aos $25 \%$ destinados à MDE. Portanto, não se trata de um programa que visa a substituir o papel do Estado em gerir os gastos em educação. A Lei 13.991/2005, que institui o PTRF, determina que:

Art. $3^{\text {o }}$ Os recursos transferidos ao Programa destinam-se à cobertura de despesas de custeio, manutenção dos equipamentos existentes, conservação das instalações físicas do sistema de ensino, e de pequenos investimentos, de forma a contribuir supletivamente para a garantia do funcionamento das unidades educacionais [...]. (SÃO PAULO, 2005c, grifo nosso)

Objetivamente, o comprometimento do orçamento para a educação com o PTRF, em termos de montantes, não representa uma transferência significativa para que se possa alegar que é uma ação de desresponsabilização do Estado. Inclusive, percentualmente às despesas em educação, os recursos gastos no programa têm diminuído, conforme demonstra a Tabela 2.

Ao se comparar a taxa de crescimento das despesas do PTRF, de MDE (25\%) e de MDE mais as despesas com a Educação Inclusiva (31\%), representadas no Gráfico 1, percebe-se que o comportamento dos gastos assume movimentação oposta. Enquanto estas têm crescido, as despesas com o PTRF têm se mantido muito próximas dos valores iniciais do programa.

Gráfico 1 - Taxa de crescimento das despesas em educação e do PTRF, por ano (em \%)

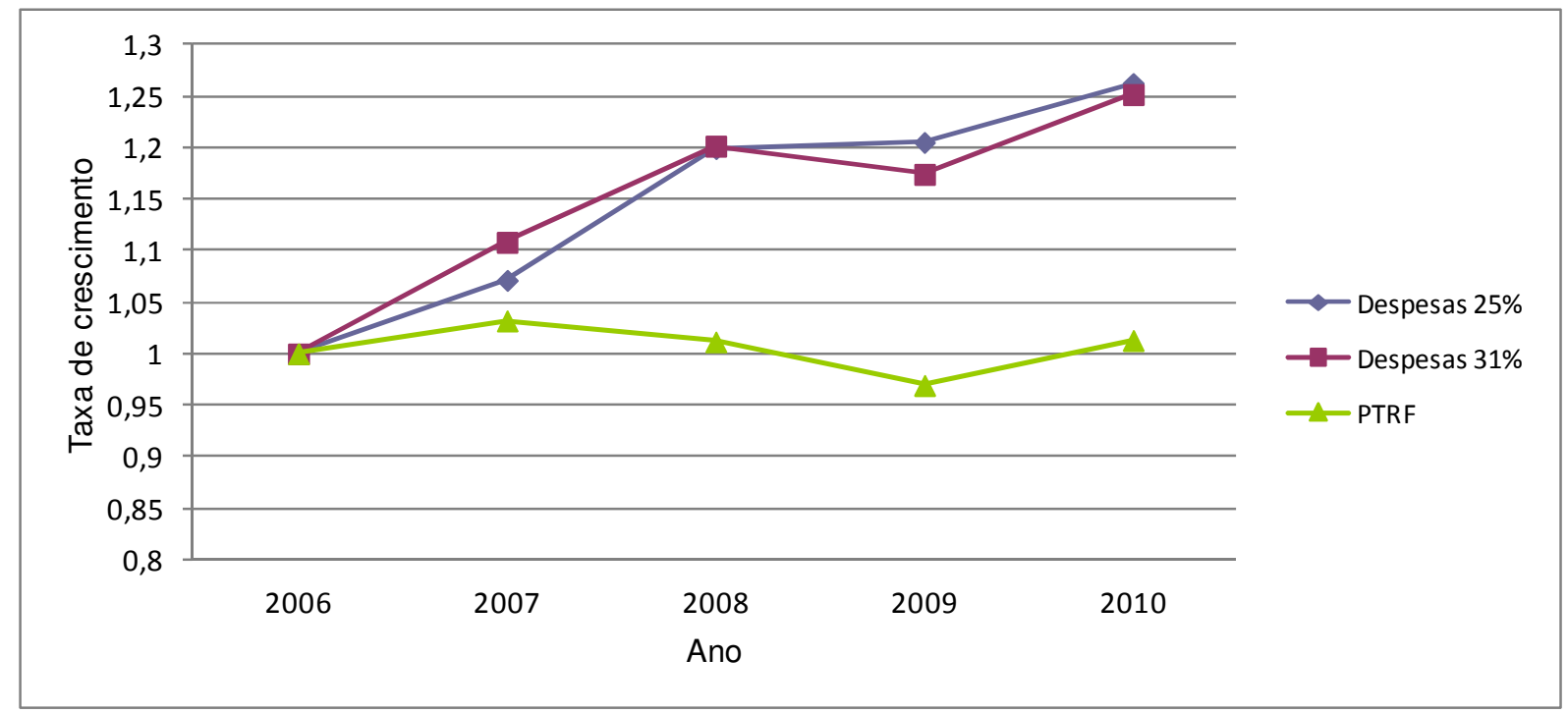

Fonte: Elaborado pelo autor, com base nos dados da Sempla. Valores deflacionados para 12/2010, pelo INPC (IBGE). 
Evidentemente, o crescimento das despesas tem também relação com o aumento da arrecadação de receitas de impostos. As despesas com o PTRF, porém, não assumem a mesma lógica.

Observado o comportamento da taxa de crescimento das despesas, deve-se refletir se esses recursos são suficientes para cobrir as despesas a que se pretende. Ao destinar para as escolas um valor insuficiente para arcar com as atribuições também transferidas, pode, de certa forma, desresponsabilizar o Estado em garantir o direito à educação de qualidade e deixar as escolas a sua própria sorte. A pesquisa de campo ajuda a investigar se esses recursos financeiros transferidos para as escolas são suficientes para realizar as atribuições a elas imputadas.

No âmbito geral do programa, surgem as questões: quem decide os totais de recursos para o programa? Quais critérios são utilizados para essa tomada de decisão? Ao ser questionada sobre essas questões, a presidente da Comissão Técnica, Sônia Medeiros, disse que quem define os montantes é a Sempla. Contudo, também disse que anualmente o secretário discute com o Núcleo de Planejamento Central (NPC), com base nas considerações trazidas pelas escolas e então faz sugestões à Sempla.

Sônia Medeiros afirmou, ainda, em entrevista, que havia uma expectativa de redução nos recursos, pois o NPC já havia anunciado cortes. À época da entrevista, não havia saído a previsão orçamentária para a LOA. Contraditoriamente, na previsão orçamentária para 2011, as despesas com a Secretaria de Educação aumentaram em torno de 1 bilhão em termos nominais, passando de 5,967 bilhões, em 2010, para 6,978 bilhões, em $2011^{17}$. Inclusive, o cálculo dos montantes de repasse do PTRF para o ano de 2011 foi maior.

Ao ser questionada sobre quais eram as solicitações das escolas sobre o programa, a presidente da Comissão Técnica respondeu que somente as Emeis e os CEIs reivindicaram aumento dos recursos do PTRF. Na Tabela 3, pode-se observar a divisão dos montantes destinados à educação infantil e ao ensino fundamental.

\footnotetext{
${ }^{17}$ Trata-se de previsão orçamentária, pois, em 2010, foram executados 6,243 bilhões. Dados obtidos no site da Sempla. Disponível em: <http://sempla.prefeitura.sp.gov.br/orc_homenew.php>. Acesso em: 21 mar. 2011.
} 
Tabela 3 - Despesas do PTRF na educação infantil e no ensino fundamental por ano (em R $\$$ e $\%)$

\begin{tabular}{|c|c|c|c|c|c|}
\hline \multirow{2}{*}{ Ano } & \multicolumn{2}{|c|}{ Educação Infantil } & \multicolumn{2}{|c|}{ Ensino Fundamental* } & \multirow{2}{*}{$\begin{array}{c}\text { Total } \\
\text { (R\$) }\end{array}$} \\
\hline & $(\mathbf{R} \$)$ & (\%) & $(\mathrm{R} \$)$ & (\%) & \\
\hline 2006 & 20.552 .299 & 45 & 25.387 .385 & 55 & 45.939 .684 \\
\hline 2007 & 21.757 .198 & 46 & 25.649 .474 & 54 & 47.406 .672 \\
\hline 2008 & 22.258 .412 & 48 & 24.208 .697 & 52 & 46.467 .109 \\
\hline 2009 & 20.894 .892 & 47 & 23.628 .218 & 53 & 44.523 .111 \\
\hline 2010 & 22.203 .168 & 48 & 24.329 .679 & 52 & 46.532 .847 \\
\hline
\end{tabular}

* As 8 escolas de ensino médio da rede municipal estão incluídas aqui, pois são Escolas Municipais de Ensino Fundamental e Ensino Médio (Emefem).

Fonte: Elaborada pelo autor, com base nos dados da Sempla. Valores deflacionados para 12/2010, pelo INPC (IBGE).

Conforme a Tabela 3, os gastos do PTRF com o ensino fundamental é ligeiramente superior aos gastos com a educação infantil. O ano de 2006 registrou a maior diferença entre educação infantil (45\%) e ensino fundamental (55\%), e a menor foi em 2008 e 2010, quando a educação infantil realizou $48 \%$ dos gastos contra $52 \%$ pelo ensino fundamental. É interessante notar que a rede municipal de ensino possuía, em 2011, 864 escolas de educação infantil e 541 escolas de ensino fundamental ${ }^{18}$. Para compreender o porquê dessa proporção invertida, devem-se observar os critérios de cálculo dos repasses, organizados no Quadro 3.

\footnotetext{
${ }^{18}$ Dados da SME. Disponível em: <http://portalsme.prefeitura.sp.gov.br/AnonimoSistema/BannerTexto.aspx?MenuBannerID=22>. Acesso em: 21 mar. 2011.
} 
Quadro 3 - Fórmula do cálculo para repasse do PTRF, por ano.

\begin{tabular}{|c|c|c|c|c|c|c|c|c|c|c|c|c|c|c|c|c|c|c|c|c|}
\hline Ano & \multicolumn{5}{|c|}{2006} & \multicolumn{6}{|c|}{2007} & \multicolumn{3}{|c|}{2008} & \multicolumn{3}{|c|}{2009} & \multicolumn{3}{|c|}{2010} \\
\hline Portarias & \multicolumn{2}{|c|}{$\begin{array}{c}\text { Portaria } 6686 / 05 \\
\left(1^{\circ} \text { repasse }\right)\end{array}$} & \multicolumn{3}{|c|}{$\begin{array}{c}\text { Portaria } 2254 / 06\left(2^{\circ}, 3^{0} \mathrm{e}\right. \\
\left.4^{\circ} \text { repasse }\right)\end{array}$} & \multicolumn{3}{|c|}{$\begin{array}{c}\text { Portaria 1876/07 (10 } \\
\text { repasse) }\end{array}$} & \multicolumn{3}{|c|}{$\begin{array}{c}\text { Portaria } 3615 / 07\left(2^{\circ} \text { e } 3^{0}\right. \\
\text { repasse })\end{array}$} & \multicolumn{3}{|c|}{ Portaria 1505/08 } & \multicolumn{3}{|c|}{ Portaria 1758/09 } & \multicolumn{3}{|c|}{ Portaria 2001/10 } \\
\hline Variáveis & $\begin{array}{l}\text { №de } \\
\text { alunos }\end{array}$ & $\begin{array}{l}\text { Valor } \\
\text { por UE }\end{array}$ & $\begin{array}{c}\text { №de } \\
\text { alunos }\end{array}$ & VF & VV & $\begin{array}{l}\text { Node } \\
\text { alunos }\end{array}$ & VF & VV & $\begin{array}{l}\text { №de } \\
\text { alunos }\end{array}$ & VF & VV & \begin{tabular}{|c|} 
№de \\
alunos \\
\end{tabular} & VF & VV & $\begin{array}{l}\text { №de } \\
\text { alunos }\end{array}$ & VF & VV & \begin{tabular}{|l|} 
\\
Node \\
alunos
\end{tabular} & VF & VV \\
\hline \multirow{2}{*}{$\begin{array}{l}C \\
E \\
I\end{array}$} & \multirow[b]{2}{*}{$\begin{array}{l}40 a \\
400\end{array}$} & \multirow[b]{2}{*}{5000} & Até 200 & 2500 & \multirow{2}{*}{$\begin{array}{c}\mathrm{NA} \times \mathrm{R} \$ \\
1,00\end{array}$} & Até 200 & 2500 & \multirow{2}{*}{$\begin{array}{c}N A \times R \$ \\
1,00\end{array}$} & Até 200 & 3750 & \multirow{2}{*}{$\begin{array}{c}\mathrm{NA} \times \mathrm{R} \$ \\
1,50\end{array}$} & Até 200 & 3333 & \multirow{2}{*}{$\begin{array}{c}\mathrm{NA} \times \mathrm{R} \$ \\
1,35\end{array}$} & Até 200 & 3333 & \multirow{2}{*}{$\begin{array}{c}\mathrm{NA} \times \mathrm{R} \\
1,35\end{array}$} & Até 200 & 4000 & \multirow{2}{*}{$\begin{array}{c}N A \times R \$ \\
2,00\end{array}$} \\
\hline & & & $\begin{array}{l}\text { Acima } \\
\text { de } 200\end{array}$ & 3000 & & $\begin{array}{l}\text { Acima } \\
\text { de } 200\end{array}$ & 3000 & & $\begin{array}{l}\text { Acima } \\
\text { de } 200\end{array}$ & 4500 & & $\begin{array}{l}\text { Acima } \\
\text { de } 200\end{array}$ & 4000 & & $\begin{array}{l}\text { Acima } \\
\text { de } 200\end{array}$ & 4000 & & $\begin{array}{l}\text { Acima } \\
\text { de } 200\end{array}$ & 4800 & \\
\hline \multirow{3}{*}{$\begin{array}{c}E \\
M \\
E \\
I\end{array}$} & 400 & 6500 & Até 400 & 6500 & \multirow{3}{*}{$\begin{array}{c}N A \times R \$ \\
1,50\end{array}$} & Até 400 & 6500 & \multirow{3}{*}{$\begin{array}{c}N A \times R \$ \\
1,50\end{array}$} & Até 400 & 9750 & \multirow{3}{*}{$\begin{array}{c}N A \times R \$ \\
2,25\end{array}$} & Até 400 & 8667 & \multirow{3}{*}{$\begin{array}{c}N A \times R \$ \\
2,00\end{array}$} & Até 400 & 8667 & \multirow{3}{*}{$\begin{array}{c}N A \times R \\
2,00\end{array}$} & Até 400 & 9100 & \multirow{3}{*}{$\begin{array}{c}N A \times R \$ \\
2,00\end{array}$} \\
\hline & $\begin{array}{l}401 \mathrm{a} \\
800\end{array}$ & 7500 & $\begin{array}{l}401 a \\
800\end{array}$ & 7500 & & $\begin{array}{l}401 \mathrm{a} \\
800\end{array}$ & 7500 & & $\begin{array}{l}401 \mathrm{a} \\
800\end{array}$ & 11250 & & $\begin{array}{l}401 a \\
800\end{array}$ & 10000 & & $\begin{array}{l}401 a \\
800\end{array}$ & 10000 & & $\begin{array}{l}401 \mathrm{a} \\
800\end{array}$ & 10500 & \\
\hline & \begin{tabular}{|l|}
$801 \mathrm{a}$ \\
1131
\end{tabular} & 8500 & $\begin{array}{l}\text { Acima } \\
\text { de } 800\end{array}$ & 8500 & & $\begin{array}{l}\text { Acima } \\
\text { de } 800\end{array}$ & 8500 & & $\begin{array}{l}\text { Acima } \\
\text { de } 800\end{array}$ & 12750 & & $\begin{array}{l}\text { Acima } \\
\text { de } 800\end{array}$ & 11333 & & $\begin{array}{l}\text { Acima } \\
\text { de } 800\end{array}$ & 11333 & & $\begin{array}{l}\text { Acima } \\
\text { de } 800\end{array}$ & 11800 & \\
\hline \multirow{5}{*}{$\begin{array}{c}\mathrm{E} \\
\mathbf{M} \\
\mathbf{E} \\
\mathbf{F} \\
/ \\
\mathbf{E} \\
\mathbf{M}\end{array}$} & 800 & 7500 & Até 800 & 7500 & \multirow{5}{*}{$\begin{array}{c}N A \times R \$ \\
2,00\end{array}$} & Até 800 & 7500 & & Até 800 & 11250 & & Até 800 & 10000 & & Até 800 & 10000 & & Até 800 & 10800 & \\
\hline & $801 \mathrm{a}$ & & $801 \mathrm{a}$ & & & $801 \mathrm{a}$ & & & $801 \mathrm{a}$ & & & $801 \mathrm{a}$ & & & $801 \mathrm{a}$ & & & $801 \mathrm{a}$ & & \\
\hline & 1500 & 8500 & 1500 & 8500 & & 1500 & 8500 & & 1500 & 12750 & & 1500 & 11333 & & 1500 & 11333 & & 1500 & 12200 & \\
\hline & $\begin{array}{l}1501 \mathrm{a} \\
2200\end{array}$ & 9500 & $\begin{array}{l}1501 \mathrm{a} \\
2200\end{array}$ & 9500 & & $\begin{array}{l}1501 \mathrm{a} \\
2200\end{array}$ & 9500 & $\begin{array}{c}2,00 \\
2,00\end{array}$ & $\begin{array}{l}1501 \mathrm{a} \\
2200\end{array}$ & 14250 & 3,00 & $\begin{array}{l}1501 \mathrm{a} \\
2200\end{array}$ & 12667 & 2,65 & $\begin{array}{l}1501 \mathrm{a} \\
2200\end{array}$ & 12667 & 2,65 & $\begin{array}{l}1501 \mathrm{a} \\
2200\end{array}$ & 13500 & $\begin{array}{l}3,00 \times \bar{\phi} \\
3,00\end{array}$ \\
\hline & $\begin{array}{l}2201 \mathrm{a} \\
3500\end{array}$ & 10500 & $\begin{array}{l}\text { Acima } \\
\text { de } 2200\end{array}$ & 10500 & & $\begin{array}{l}\text { Acima } \\
\text { de } 2200\end{array}$ & 10500 & & $\begin{array}{l}\text { Acima } \\
\text { de } 2200\end{array}$ & 15750 & & $\begin{array}{l}\text { Acima } \\
\text { de } 2200\end{array}$ & 14000 & & $\begin{array}{l}\text { Acima } \\
\text { de } 2200\end{array}$ & 14000 & & $\begin{array}{l}\text { Acima } \\
\text { de } 2200\end{array}$ & 15000 & \\
\hline & $\begin{array}{l}150 \mathrm{a} \\
250\end{array}$ & 7500 & Até 250 & 7500 & & Até 250 & 7500 & & Até 250 & 11250 & & Até 250 & 10000 & & Até 250 & 10000 & & Até 250 & 10800 & \\
\hline$E$ & $251 a$ & & $251 a$ & & $N A \times R \$$ & $251 \mathrm{a}$ & & $N A \times R \$$ & $251 \mathrm{a}$ & & $N A \times R \$$ & $251 \mathrm{a}$ & & $N A \times R \$$ & $251 \mathrm{a}$ & & $N A \times R$ & $251 \mathrm{a}$ & & $N A \times R \$$ \\
\hline$M$ & 350 & 8500 & 350 & 8500 & 2,00 & 350 & 8500 & 2,00 & 350 & 12750 & 3,00 & 350 & 11333 & 2,65 & 350 & 11333 & 2,65 & 350 & 12200 & 3,00 \\
\hline $\begin{array}{l}E \\
E\end{array}$ & $\begin{array}{l}351 \mathrm{a} \\
500\end{array}$ & 9500 & $\begin{array}{l}\text { Acima } \\
\text { de } 350\end{array}$ & 9500 & & $\begin{array}{l}\text { Acima } \\
\text { de } 350\end{array}$ & 9500 & & $\begin{array}{l}\text { Acima } \\
\text { de } 350\end{array}$ & 14250 & & $\begin{array}{l}\text { Acima } \\
\text { de } 350\end{array}$ & 12667 & & $\begin{array}{l}\text { Acima } \\
\text { de } 350\end{array}$ & 12667 & & $\begin{array}{l}\text { Acima } \\
\text { de } 350\end{array}$ & 13500 & \\
\hline
\end{tabular}

Legenda: $\mathbf{U E}=$ unidade educacional; $\mathbf{V F}=$ valor fixo; $\mathbf{V V}=$ valor variável; $\mathbf{N A}=$ Número de alunos matriculados.

Fonte: Elaborado pelo autor, com base nas Portarias citadas. 
Para o cálculo dos recursos financeiros do PTRF, são utilizadas quatro categorias: a) que compreendem os Centros de educação infantil (CEIs), os quais atendem crianças de 0 a 3 anos; b) que compreendem as Escolas Municipais de Educação Infantil (Emeis, as quais atendem crianças de 4 a $6 \operatorname{anos}^{19}$; c) que compreendem as Escolas Municipais de Ensino Fundamental (Emefs), as quais atendem alunos do ensino regular e também na modalidade de educação de jovens e adultos no ensino fundamental e as Escolas Municipais de Ensino Fundamental e Ensino Médio (Emefems), que atendem ao ensino fundamental e também ao ensino médio; d) que compreendem as Escolas Municipais de Educação Especial (Emee), que atendem alunos surdos e, a partir de 2012, passam a se chamar Escolas Municipais de Educação Bilíngue para Surdos (Emebs).

No primeiro ano do PTRF, o critério adotado para o cálculo do repasse foi "valor fixo", por faixa de número de matrículas do ano anterior apuradas pelo Censo Escolar/Inep 2004 e por tipo de estabelecimento. A partir do segundo repasse, de 2006, é acrescido ao cálculo um "valor variável”, que corresponde a um determinado valor por matrícula.

Para cada categoria de escola, foram atribuídas faixas de número de alunos (no período analisado, as faixas não tiveram alterações), que correspondiam a um valor fixo. Os CEIs tinham duas: até 200 e acima de 200 alunos; as Emeis tinham três: até 400, de 401 a 800, e acima de 800 alunos; as Emefs e Emefems tinham quatro: até 800, de 801 a 1.500, 1.501 a 2.200, e acima de 2.200 alunos; e as Emees tinham três faixas: até 250, de 251 a 350 , e acima de 350 .

Conforme o Quadro 3, no ano 2010, os CEIs têm o seu maior valor por aluno matriculado ( $\mathrm{R}$ \$ 2) e também o valor fixo ( $\mathrm{R} \$ 4$ mil para escolas com até 200 alunos e R\$ 4.800,00, acima de 200 alunos). As Emeis têm seu maior valor por aluno matriculado (R\$ 2,25 ) e valor fixo ( $\mathrm{R} \$ 9.750,00$, para escolas com até 400 alunos; $\mathrm{R} \$ 11.250,00$, de 401 a 800 alunos; e R\$12.750,00, acima de 800 alunos) no $2^{\circ}$ e $3^{\circ}$ repasses do ano de 2007. As Emefs e Emefems têm seu maior valor por aluno matriculado (R\$3) no $2^{\underline{o}}$ e $3^{\mathrm{o}}$ repasses do ano de 2007 e também no ano de 2010 , e o maior valor fixo atribuído é registrado no $2^{\underline{0}}$ e $3^{\circ}$ repasses de 2007 (R \$ 11.250,00 para escolas com até 800 alunos; $\mathrm{R} \$ 12.750,00$, de 801 a 1.500 alunos; R\$ 14.250,00, de 1.501 a 2.200 alunos; e R\$15.750,00, acima de 2.200 alunos). As Emees têm seu maior valor por aluno matriculado (R\$ 3) no $2^{\circ}$ e $3^{\circ}$ repasses do ano de 2007 e também no ano de 2010, e o maior valor fixo atribuído é registrado no $2^{\underline{o}}$ e $3^{\underline{o}}$ repasses de

\footnotetext{
${ }^{19}$ A partir de 2010, a rede municipal de São Paulo implementou o ensino fundamental de nove anos com início aos seis anos de idade.
} 
2007 (R\$ 11.250,00, para escolas com até 250 alunos; $\mathrm{R} \$ 12.750,00$, de 251 a 350 alunos; e $\mathrm{R} \$ 14.250,00$, acima de 350 alunos).

Segundo os dados disponibilizados pela SME, dos 357 CEIs, $85 \%$ têm até 200 alunos, concentrando na primeira faixa de critério em todos os anos para repasse dos recursos do PTRF. Das Emeis, 59\% têm até 400 alunos, enquadrando-se na primeira faixa do critério de repasse, e 31\% têm de 401 até 800 alunos, correspondentes à segunda faixa. No ensino fundamental, as escolas se concentram na segunda faixa de critério, de 801 a 1.500 alunos, com 54\% das Emefs, mas há também um número significativo de escolas que estão na primeira faixa de até 800 alunos, $31 \%$ (Anexo A). Os dados das Emees e Emefems não foram registrados aqui, porque não fazem parte da pesquisa de campo.

A fórmula dos repasses atribui valores inferiores para a educação infantil, em relação ao ensino fundamental, tanto no "valor fixo" quanto no "valor variável". Essa situação agrava-se, ao comparar os valores de repasse para os CEIs em relação às Emefs.

Em 31 de março de 2010, logo após a aprovação da Portaria 2001, de 26 de março de 2010, a Prefeitura de São Paulo publica em seu site que os recursos do PTRF teriam aumento de 41,7 milhões para 46,7 milhões. Mas, como identificado na Tabela 1 e no Gráfico 1, o aumento anunciado de 2009 para 2010, se deflacionados, é pouco significativo e inferior ao praticados no ano de 2007. Na mesma matéria, destaca-se o aumento de $20 \%$ para os CEIs, $5 \%$ para as Emeis e 8\% para as Emefs.

Para exemplificar o comportamento dos montantes anuais calculados para cada escola, realizou-se a projeção dos recursos por tipo de escola. Atribuiu-se um intervalo de crescimento arbitrário de 35 alunos para produzir a tendência dos montantes, por escola, que gerou o Gráfico 2, referente aos critérios estabelecidos para o ano de 2009, e o Gráfico 3, sobre os critérios estabelecidos para o ano de 2010. 
Gráfico 2 - Comportamento dos montantes de recursos, segundo os critérios para 2009 (em $\mathrm{R} \$$ /Matrículas)

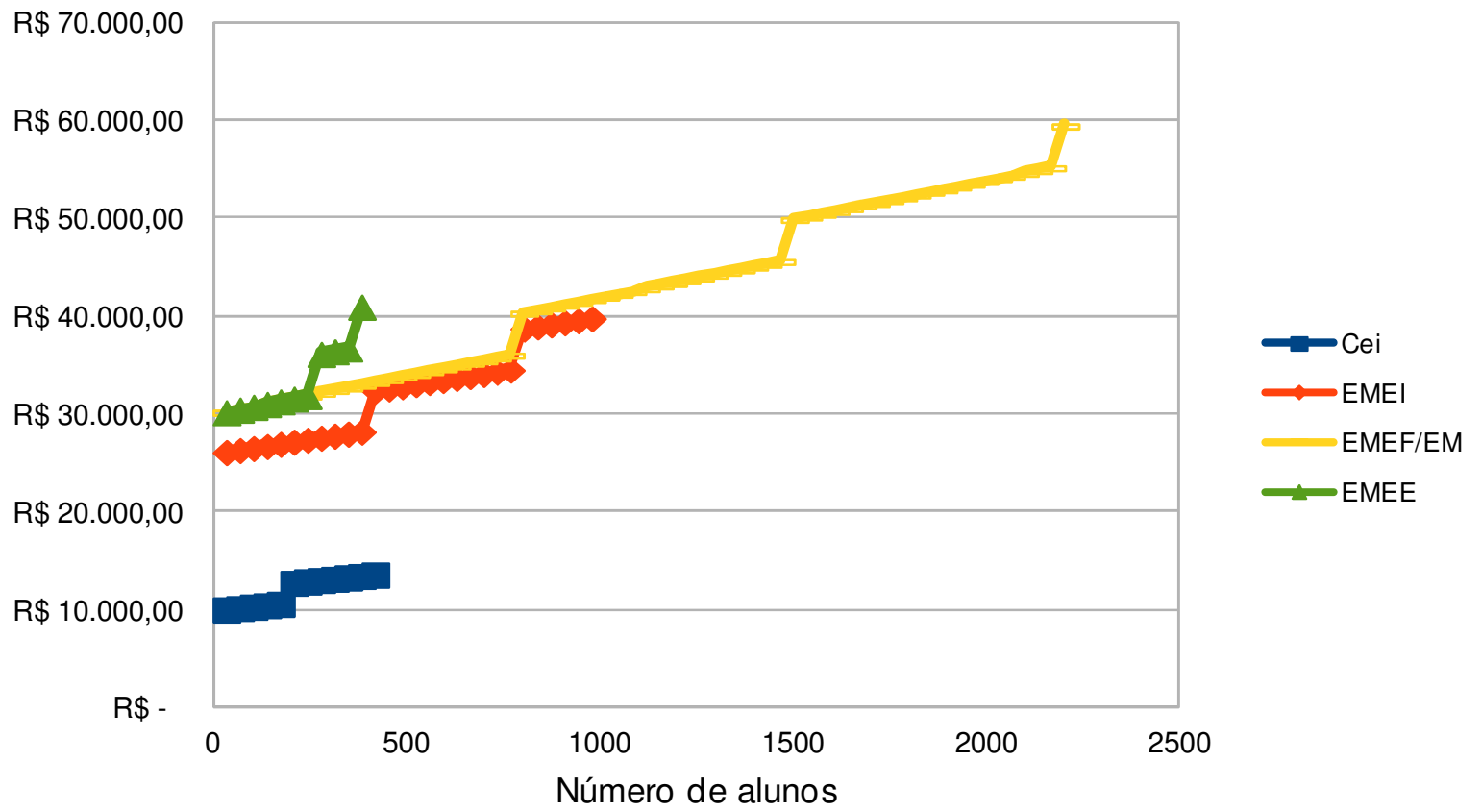

Fonte: Elaborado pelo autor, com base nos critérios da Portaria SME 1758/2009, considerando uma escala hipotética de alunos por escola com intervalos de 35 alunos.

Gráfico 3 - Comportamento dos montantes de recursos, segundo os critérios para 2010 (em $\mathrm{R} \$$ /Matrículas)

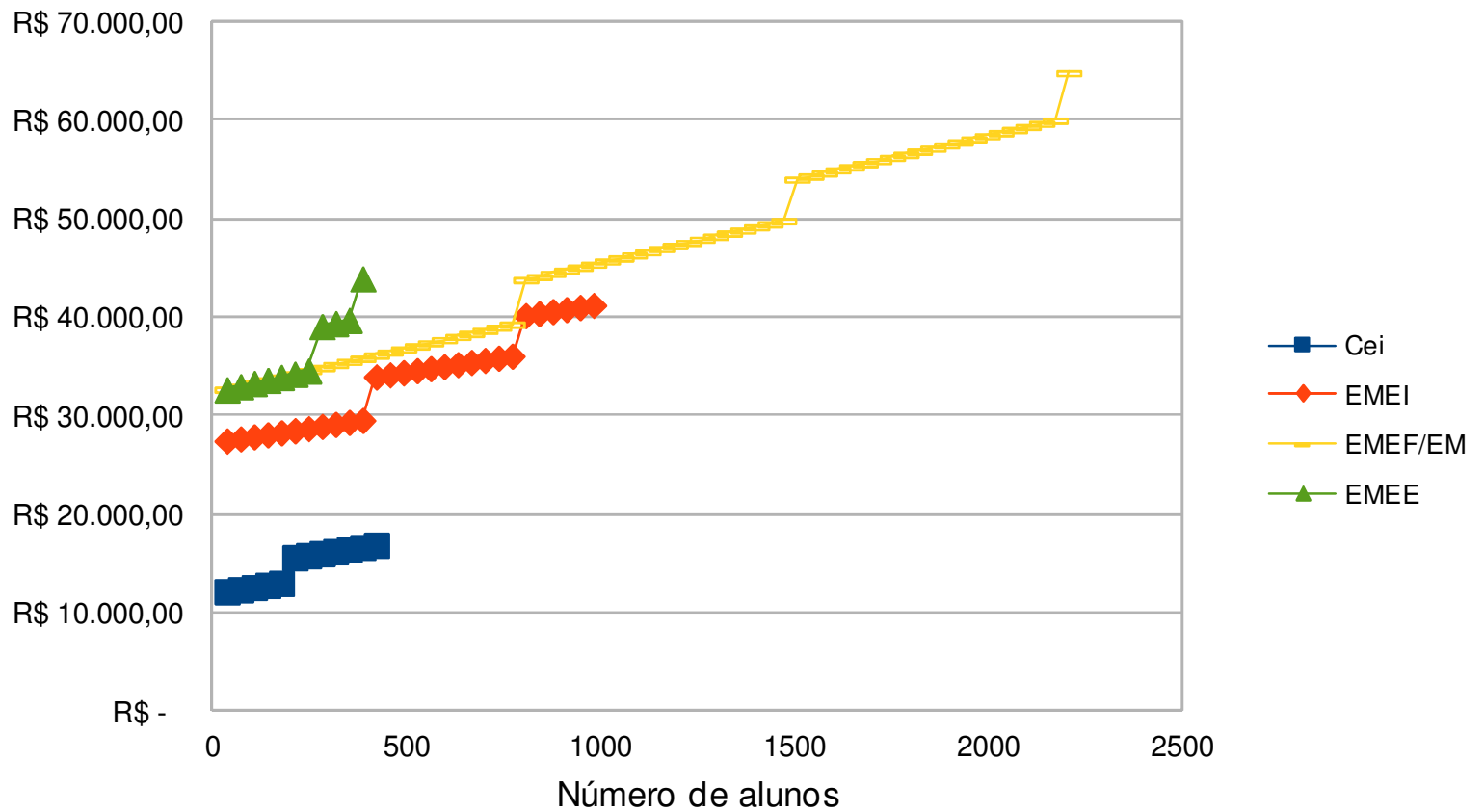

Fonte: Elaborado pelo autor, com base nos critérios da Portaria SME 2001/2010, considerando uma escala hipotética de alunos por escola com intervalos de 35 alunos. 
O Gráfico 2 e o Gráfico 3 ilustram o comportamento dos repasses para a escola para os anos de 2009 e 2010, quando se observa uma tendência de crescimento com alguns "saltos", produzidos pela mudança de faixa de alunos. Assim, do final de uma faixa para o início de outra, há crescimento no montante, devido aos valores fixos atribuídos.

Observa-se, também, um aumento do valor do repasse do ano de 2009 para 2010, contudo, o comportamento dos montantes dos repasses não se altera e os repasses para os CEIs continuam muito inferiores aos outros praticados.

Contudo, ao realizarem-se os cálculos por aluno-ano, considerando o número máximo de alunos da primeira faixa do repasse do PTRF, para o ano de 2010, obtemos valores superiores para a Emei e para o CEI em relação às Emefs, conforme demonstra a Tabela 4.

Tabela 4 - Valores totais do PTRF, por ano, e valor por aluno/por ano, 2010

\begin{tabular}{cccc}
\hline $\begin{array}{c}\text { Tipo de } \\
\text { escola }\end{array}$ & $\begin{array}{c}\text { Número de } \\
\text { alunos }\end{array}$ & $\begin{array}{c}\text { Total por } \\
\text { escola/ano } \\
\text { (R\$) }\end{array}$ & $\begin{array}{c}\text { Valor por } \\
\text { aluno/ano } \\
\text { (R\$) }\end{array}$ \\
\hline CEI & 200 & 13200 & 66 \\
EMEI & 400 & 29700 & 74 \\
EMEF & 800 & 39600 & 50 \\
EMEE & 250 & 34650 & 139 \\
\hline
\end{tabular}

Fonte: Elaborado pelo autor, com base nos critérios da Portaria SME 2001/2010

É importante ressaltar que, embora a educação infantil atenda um número menor de alunos, o período de permanência nas escolas é superior ao do ensino fundamental, e muitas das necessidades de serviços para manutenção do prédio são equivalentes, independentemente das características específicas dos tipos de unidade educacionais. Assim, ao se igualar o número de alunos nas escolas para 200, os valores seriam: R\$ 66 para o CEI; R \$ 142,50 para a Emei; R\$ 171 para a Emef; e R \$ 171 para a Emee. Logo, pode-se verificar uma distorção no cálculo entre a educação infantil e o ensino fundamental. Observando-se os montantes, por ano, fica mais clara ainda a desproporção, na medida em que o CEI recebe, por ano, 33\% e a Emei, $75 \%$ do valor destinado à Emef.

Além das comparações entre o cálculo para destinação de recursos financeiros entre os tipos de escola, torna-se importante discutir se esses montantes estão dentro de uma condição aceitável para atender às necessidades que o próprio programa se propõe a cobrir. Para 
estabelecer um parâmetro de comparação, será utilizado parte do cálculo do Custo AlunoQualidade Inicial (CAQi).

O CAQi é uma proposta da Campanha Nacional pelo Direito à Educação com vistas a colaborar com a construção do Custo Aluno-Qualidade, previsto na CF/88, na LDB/96, na lei do Fundef e no Plano Nacional de Educação (Lei 10.172/2001). Por meio de oficinas, a Campanha Nacional pelo Direito à Educação estabeleceu discussão com especialistas, lideranças da sociedade civil e autoridades governamentais. Fruto dessas oficinas, Denise Carreira e José Marcelino Rezende Pinto produziram uma síntese e proposta publicada, em 2007, no livro Custo Aluno-Qualidade Inicial: rumo à educação pública de qualidade no Brasil.

Como custo de bens e serviços, o CAQi considera um valor de R \$ 100/aluno-ano para desenvolvimento de projetos de ações pedagógicas para todos os tipos de escolas (creche, préescola/ $1^{\underline{a}}$ a $4^{\underline{a}}$ série e $5^{\mathrm{a}}$ a $8^{\mathrm{a}}$ série/ensino médio) (CARREIRA; PINTO, 2007). Comparado aos recursos financeiros que o PTRF disponibiliza para as escolas, o único valor aluno-ano que supera é o da Emee, no valor de R \$ 138,60. Contudo, projetos de ações pedagógicas são somente parte dos itens que o PTRF se propõe a realizar, restando, ainda, a manutenção e adequação predial, a aquisição de bens materiais, o material de expediente para a secretaria, entre outros.

Portanto, do ponto de vista da construção de uma educação pública, gratuita e de qualidade, os recursos do PTRF se mostram insuficientes. Evidentemente, não é o programa que resolverá essa questão no Brasil, mas a inversão da opção política dos governos de não investir em educação. Constatar que as escolas recebem recursos insuficientes, bem como o aumento de suas atribuições, no entanto, fortalecem a tese de que a escola pública continua sendo sucateada.

\subsection{Despesas do PTRF por categoria econômica}

Outra questão importante a ser analisada sobre a aplicação dos recursos do PTRF é a possibilidade de gastos na categoria econômica de custeio e capital. A divisão das despesas, por categoria econômica, pode ser vista na Tabela 5. 
Tabela 5 - Despesas do PTRF por categoria econômica, por ano (em R\$ e \%)

\begin{tabular}{|c|c|c|c|c|c|c|c|c|c|c|}
\hline \multirow[b]{2}{*}{ Despesas } & \multicolumn{2}{|l|}{2006} & \multicolumn{2}{|l|}{2007} & \multicolumn{2}{|l|}{2008} & \multicolumn{2}{|l|}{2009} & \multicolumn{2}{|l|}{2010} \\
\hline & $(\mathrm{R} \$)$ & (\%) & $(\mathrm{R} \$)$ & (\%) & $(\mathrm{R} \$)$ & (\%) & $(\mathrm{R} \$)$ & (\%) & $(\mathrm{R} \$)$ & (\%) \\
\hline Total em custeio & 43.502 .874 & 95 & 37.808 .490 & 80 & 37.160 .587 & 80 & 35.608 .013 & 80 & 36.920 .463 & 79 \\
\hline Total em capital & 2.436 .810 & & 9.598 .182 & 20 & 9.306 .522 & $20^{\circ}$ & 8.915 .098 & 20 & 9.612 .384 & 21 \\
\hline Total & 45.939 .684 & 100 & $47.406 .672^{\prime}$ & 100 & $46.467 .109^{r}$ & 100 & $44.523 .111^{\circ}$ & 100 & 46.532 .847 & 100 \\
\hline
\end{tabular}

Fonte: Elaborada pelo autor, com base nos dados da Sempla. Valores deflacionados para 12/2010, pelo INPC (IBGE).

Conforme apresentado no item 3.3 deste capítulo, tanto para o ano de 2005 quanto para o de 2006 havia discrepâncias na legislação sobre o gasto em despesas de capital. Então, pode-se verificar pelos percentuais das despesas por categoria econômica: uma interpretação de que os recursos não se destinavam para despesas de capital, gerando uma insegurança na execução do gasto.

Em 2006, no $4^{0}$ repasse, algumas escolas recebem os recursos financeiros divididos em custeio e capital, como se pode constatar pela pesquisa de campo. Contudo, somente a Portaria 1876/2007, que estabelece o cálculo para repasse do PTRF e o período para realização das despesas, determina mais claramente que os recursos eram para "cobertura das despesas de custeio e aquisição de bens permanentes" (SÃO PAULO, 2007b). Mesmo assim, em 29 de junho de 2007, a SME edita a Portaria 3615/2007, que institui maior prazo para a realização do $2^{\underline{0}}$ e do $3^{0}$ repasses. Também determina, no item 2.1.1, do Anexo I, que os valores seriam divididos em $80 \%$ para custeio e $20 \%$ para capital, correspondendo aos percentuais apurados na Tabela 5.

Em 2008 e 2009, as portarias que determinam os cálculos dos repasses trazem a definição de $80 \%$ para despesas de custeio e $20 \%$ para despesas de capital, novamente confirmada na apuração pela Tabela 5 .

Em 2010, a Portaria SME 2001/2010 determina que:

4.1. no $1^{-}$(primeiro) repasse as Unidades Educacionais receberão $20 \%$ (vinte por
cento) do valor previsto na dotação de capital e o restante na dotação de custeio;
4.2. para o segundo e terceiro repasses, o responsável pela Associação informará os
percentuais pretendidos em cada uma das dotações, através do Anexo VI, integrante
desta;
4.3. o montante cabível para o repasse deverá apresentar nas respectivas dotações,
variações iguais a múltiplos de dez, a partir de $10 \%$. (SÃO PAULO, 2010a)

Foi uma novidade na organização do PTRF, as escolas poderem determinar a divisão dos recursos por categoria econômica.

As categorias econômicas das despesas do PTRF não parecem ser uma questão menor (algumas problemáticas já foram levantadas no item 3.3). Na entrevista realizada, a presidente 
da Comissão Técnica apresenta como um dos problemas do uso indevido dos recursos o gasto de despesas de capital em custeio.

Relata, ainda, que na prestação de contas houve casos em que a DRE percebeu o desvio de uma categoria para a outra. Então, os procedimentos são: restituir os recursos ao tesouro; a DRE abre processo administrativo, podendo chegar à penalidade (e, inclusive, conta que já houve casos). Mas a presidente também afirma que, atualmente, o fluxo de informações é melhor do que no início do programa e que estão reduzindo os casos que chegam à Comissão Técnica, sendo, por vezes, resolvidos localmente, nas próprias DREs.

\subsection{Outras formas de descentralização de recursos e o PTRF}

Embora não seja objeto desta pesquisa, é importante saber que as escolas da rede municipal recebem recursos de três formas: do PTRF, do regime de adiantamento e do PDDE. Os dois primeiros têm seus recursos oriundos das receitas do município e os do último vêm da União. Além desses, as APMs, por serem entidades de direito privado sem fins lucrativos, podem captar recursos, geralmente feita em atividades promovidas nas escolas, como festas juninas, da primavera etc..

Em 1995, é criado pela Resolução 12, de 10 de maio de 1995, sob a responsabilidade do Fundo Nacional de Desenvolvimento da Educação (FNDE), o Programa de Manutenção e Desenvolvimento do Ensino Fundamental (PMDE), posteriormente denominado de Programa Dinheiro Direto na Escola (PDDE).

O PDDE destinou-se a transferir recursos para as escolas de ensino fundamental das redes estaduais e municipais, e escolas especiais mantidas por organizações não governamentais sem fins lucrativos. Para o recebimento das verbas, era necessário transformar os Conselhos de Escola, APMs, ou a Caixa Escolar, em UEx, entidades de direito privado sem fins lucrativos, como já ressaltado.

Posteriormente, em 14 de dezembro de 1998, com a edição da Medida Provisória (MP) 1.784, o PDDE é instituído com os critérios de repasse dos recursos financeiros do Programa Nacional de Alimentação Escolar, e reeditado na MP 2.178 de 24 de agosto de 2001. Em 16 de junho de 2009, é promulgada a Lei federal 11.947, passando o PDDE a 
atender todas as escolas da educação básica públicas e as filantrópicas, com convênio com o Estado.

Pelos montantes aplicados do PDDE, no período de 2006 a 2009, demonstrados pelo Gráfico 4, fica clara a ampliação do atendimento. Em 2006, os recursos transferidos às escolas da rede municipal de São Paulo eram por volta de 5,3 milhões, já em 2009, chegam a 10,2 milhões, ou seja, um aumento de quase $100 \%$.

Gráfico 4 - Despesas com o PTRF e com o PDDE, por ano (em R\$)

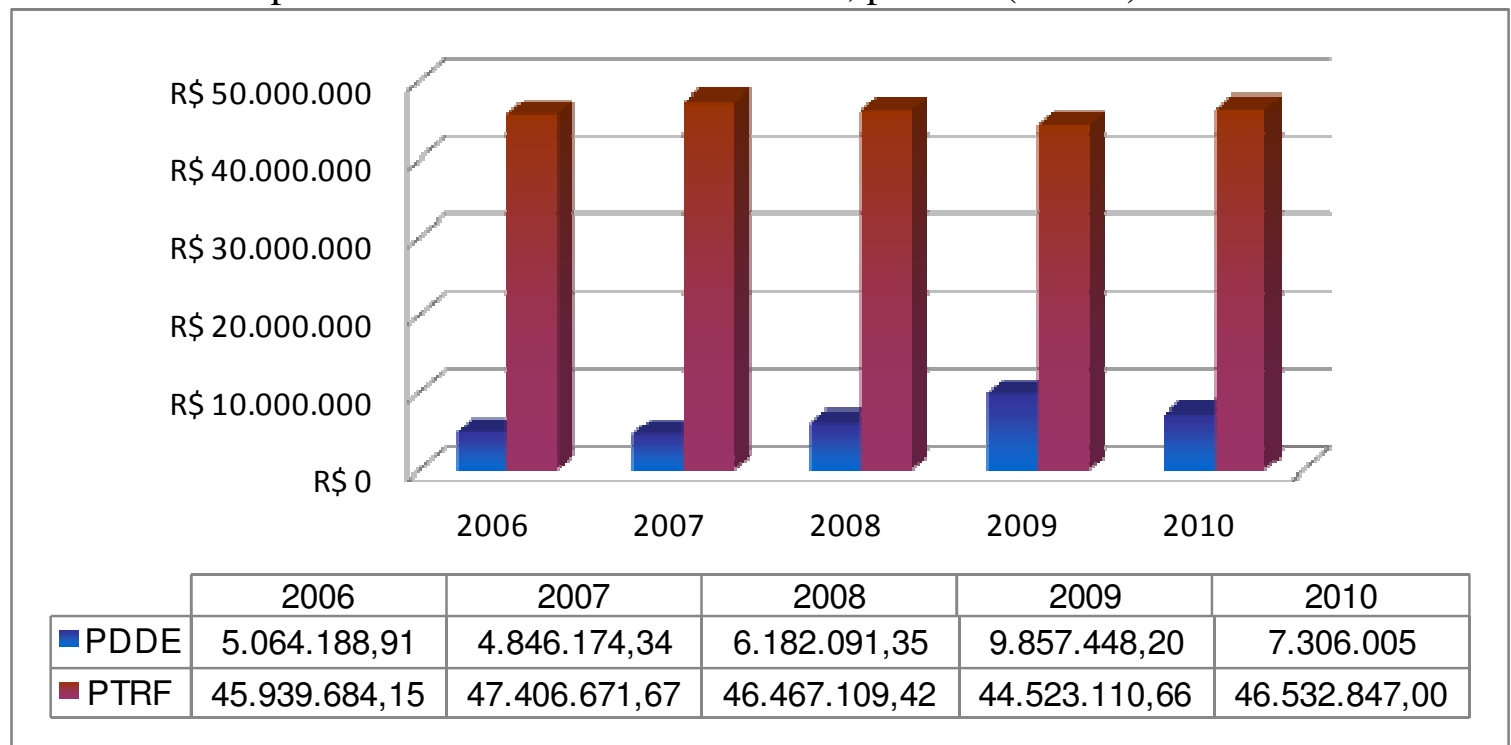

Fonte: Elaborado pelo autor, com base nos dados da Sempla. Valores deflacionados para 12/2010, pelo INPC (IBGE).

Entretanto, os recursos transferidos da União às escolas municipais são muito inferiores aos distribuídos pelo PTRF, conforme se observa no Gráfico 4. Os recursos do PDDE representam 10\% em 2006, 9\% em 2007, 12\% em 2008, 18\% em 2009 e 14\% em 2010, da somatória dos dois recursos (PTRF e PDDE). Em 2009, mesmo os recursos tendo dobrado o volume, ainda assim foram bem inferiores aos do PTRF.

A Lei federal 11.947/2009, em seu artigo 23, determina que os recursos do PDDE "serão destinados à cobertura de despesas de custeio, manutenção e de pequenos investimentos, que concorram para a garantia do funcionamento e melhoria da infraestrutura física e pedagógica dos estabelecimentos de ensino.” (BRASIL, 2009b). A Resolução/FNDE/CD/ 043, de 11 de novembro de 2005, define o critério para cálculo do repasse para as escolas, conforme Tabela 6. 
Tabela 6 - Cálculo para repasse dos recursos do PDDE para as regiões sul e sudeste e o Distrito Federal

\begin{tabular}{|c|c|c|c|}
\hline \multirow{2}{*}{$\begin{array}{l}\text { INTERVALO DE } \\
\text { CLASSE DE } \\
\text { NÚMERO DE } \\
\text { ALUNOS }\end{array}$} & \multicolumn{3}{|c|}{$\begin{array}{l}\text { REGIÃO } \\
\text { S/SE/DF }\end{array}$} \\
\hline & $\begin{array}{c}\text { VALOR BASE }^{(1)} \\
(R \$ 1,00)\end{array}$ & $\begin{array}{c}\text { FATOR DE } \\
\text { CORREÇÃO } \\
\end{array}$ & $\begin{array}{c}\text { VALOR TOTAL }^{(3)} \\
(R \$ 1,00)\end{array}$ \\
\hline 21 a 50 & 500 & $(X-21) \times K$ & $500+(X-21) \times K$ \\
\hline 51 a 99 & 1.100 & $(X-51) \times K$ & $1.100+(X-51) \times K$ \\
\hline 100 a 250 & 1.800 & $(X-100) \times K$ & $1.800+(X-100) \times K$ \\
\hline 251 a 500 & 2.700 & $(X-251) \times K$ & $2.700+(X-251) \times K$ \\
\hline 501 a 750 & 4.500 & $(X-501) \times K$ & $4.500+(X-501) \times K$ \\
\hline 751 a 1.000 & 6.200 & $(X-751) \times K$ & $6.200+(X-751) \times K$ \\
\hline 1.001 a 1.500 & 8.200 & $(X-1.001) \times K$ & $8.200+(X-1.001) \times K$ \\
\hline 1.501 a 2.000 & 11.000 & $(X-1.501) \times K$ & $11.000+(X-1.501) \times K$ \\
\hline Acima de 2.000 & 14.500 & $(X-2.000) \times K$ & $14.500+(X-2.000) \times K$ \\
\hline
\end{tabular}

(1) Valor Base: parcela mínima a ser destinada à instituição de ensino que apresentar quantidade de alunos matriculados, segundo o censo escolar, igual ao limite inferior de cada Intervalo de Classe de Número de Alunos, no qual o estabelecimento de ensino esteja situado.

${ }^{(2)}$ Fator de Correção: resultado da multiplicação da constante K pela diferença entre o número de alunos matriculados na escola e o limite inferior de cada Intervalo de Classe de Número de Alunos, no qual o estabelecimento de ensino esteja situado - (X - Limite Inferior) x $\mathrm{K}$ - representando $\mathrm{X}$ o número de alunos da escola, segundo o censo escolar, e $\mathrm{K}$ o valor adicional por aluno acima do limite inferior de cada Intervalo de Classe de Número de Alunos.

(3) Valor Total: resultado, em cada intervalo de classe, da soma horizontal do Valor Base mais o Fator de Correção.

Fonte: Resolução/FNDE/CD/ 043, de 11 de novembro de 2005.

Outra forma de descentralização de recursos financeiros na rede municipal de São Paulo é realizado por meio do regime de adiantamento, instituído pela Lei federal 4.320/1964, com regulamentação no Município de São Paulo pela Lei 10.513/1988, que consistiu em repasse de recursos ao servidor municipal para despesas de pronto pagamento.

O regime de adiantamento não se restringe à SME. Todas as transferências são precedidas de empenho, onerando dotação própria. Os recursos são destinados a despesas de pequeno vulto, manutenção de bens móveis, conservação e adaptação de bens imóveis, entre outros.

Nas escolas, as verbas utilizadas pelo regime de adiantamento são exclusivas para situações de emergência, sem a possibilidade de formar estoque ou aquisição de bens permanentes, e, geralmente, são concedidas a um servidor da equipe gestora. A utilização desses recursos não necessita de discussão em nenhum espaço como a APM ou o Conselho Escolar.

Como pode ser utilizado por qualquer unidade orçamentária, não foi possível localizar no orçamento municipal as despesas realizadas por esse mecanismo, especificamente na SME. 


\section{AS ESCOLAS PESQUISADAS E O PTRF}

Este capítulo deter-se-á ao estudo do PTRF nas escolas-campo, no período de 2006 a 2010. Assim, está organizado da seguinte maneira: análise do material documental das escolas, abarcando as atas do CE e da APM, e o projeto político pedagógico; descrição e análise dos recursos financeiros e das despesas realizadas pelas unidades; e relato da opinião dos membros da comunidade escolar sobre o programa e sua interferência no trabalho das três escolas.

Para facilitar ao leitor e garantir o sigilo das fontes de informação, serão utilizadas, para a identificação das escolas, apenas denominações genéricas: "o CEI", "a Emei" e "a Emef". Com relação aos entrevistados, pelo mesmo motivo, será empregada denominação composta, pelo segmento ao qual pertence o entrevistado, seguido de sua escola, por exemplo: "a diretora da Emei", "a mãe do CEI" etc..

As três escolas selecionadas para estudo de campo pertencem a um CEU, situado na região noroeste da cidade de São Paulo, no bairro São Leopoldo ${ }^{20}$. É constituído por um terreno de $69.466 \mathrm{~m}^{2}$ e $12.548 \mathrm{~m}^{2}$ de área construída, e iniciou seu funcionamento a partir de setembro de 2003, fazendo parte dos primeiros CEUs construídos na cidade de São Paulo, na gestão do PT (2001-2004). O CEI atende cerca de 290 crianças, a Emei, 690 e a Emef, 1.100 alunos.

Como parte da metodologia de pesquisa, foram realizadas 13 entrevistas, sendo dez com representantes dos segmentos da comunidade escolar que participam ou participaram do CE ou da APM das instituições, e três com diretoras de escola, que são membros natos dos conselhos e representantes do segmento de gestão. A seguir, no Quadro 4, está registrado o breve perfil dos dez entrevistados.

\footnotetext{
${ }^{20}$ Para manter o sigilo das fontes de informação o nome do bairro é fictício.
} 
Quadro 4 - Perfil dos entrevistados membros do CE ou APM das escolas-campo

\begin{tabular}{|c|c|c|c|c|c|c|c|}
\hline Escola & Segmento & Idade & Sexo & Escolaridade & \begin{tabular}{|lr} 
Quantos anos \\
está nessa escola
\end{tabular} & $\begin{array}{l}\text { Quantas gestões } \\
\text { do CE participou }\end{array}$ & $\begin{array}{l}\text { Quantas gestões do } \\
\text { APM participou }\end{array}$ \\
\hline \multirow{3}{*}{ CEI } & Responsáveis & 25 & $\mathrm{~F}$ & Ensino Médio & 8 & 4 & 4 \\
\hline & $\begin{array}{l}\text { Quadro de } \\
\text { apoio }\end{array}$ & 46 & $\mathrm{~F}$ & Ensino Médio & 3 & 1 & 1 \\
\hline & Docente & 49 & $\mathrm{~F}$ & $\begin{array}{l}\text { Ens. Sup. } \\
\text { Completo }\end{array}$ & 8 & 2 & 1 \\
\hline \multirow{3}{*}{ EMEI } & Responsáveis & 37 & $\mathrm{~F}$ & $\begin{array}{l}\text { Ens. Sup. } \\
\text { Completo }\end{array}$ & 3 & 3 & 3 \\
\hline & $\begin{array}{l}\text { Quadro de } \\
\text { apoio }\end{array}$ & 61 & $\mathrm{~F}$ & Ensino Médio & 9 & 8 & 0 \\
\hline & Docente & & $\mathrm{F}$ & $\begin{array}{l}\text { Ens. Sup. } \\
\text { Completo }\end{array}$ & 7 & 5 & 1 \\
\hline \multirow{4}{*}{ EMEF } & Discente & 11 & M & $6^{\mathrm{a}}$ série & 6 & 2 & 0 \\
\hline & Responsáveis & 34 & $\mathrm{~F}$ & $6^{a}$ série & 8 & 6 & 2 \\
\hline & $\begin{array}{l}\text { Quadro de } \\
\text { apoio }\end{array}$ & 38 & $\mathrm{~F}$ & $\begin{array}{l}\text { Ens. Sup. } \\
\text { Completo }\end{array}$ & 8 & 5 & 3 \\
\hline & Docente & 48 & $\mathrm{~F}$ & $\begin{array}{l}\text { Ens. Sup. } \\
\text { Completo }\end{array}$ & 7 & 7 & 7 \\
\hline
\end{tabular}

Fonte: Elaborado pelo autor.

Buscou-se entrevistar pessoas que já tivessem alguma experiência em participação em CE ou diretoria de APM, de preferência no período de análise desta pesquisa.

A diretora do CEI ingressou na prefeitura em 1998, por meio de concurso que ofereceu vagas para Diretor de Equipamento Social antes das creches passarem para a Secretaria de Educação do Município de São Paulo. É formada em Serviço Social e possui pós-graduação lato sensu em Gestão Educacional, que foi oferecida pela própria prefeitura, no processo de transformação do cargo.

A diretora da Emei ingressou como diretora efetiva em 1995. Antes disso, era professora de história da rede estadual. De 2001 a 2004 trabalhou na Coordenadoria de Ensino e Ação Educativa, gestão do PT. A partir de 2005, assumiu a direção da Emei, que é uma das escolas-campo.

A diretora da Emef iniciou a atuação na educação como professora de história da rede estadual de São Paulo em 1981. Em 1986, ingressou como comissionada na rede municipal de São Paulo, efetivando-se em 1992 e foi coordenadora pedagógica de 1995 a 2001. No período de 2001 a 2004, trabalhou como coordenadora regional de educação na Coordenadoria de 
Ensino e Ação Educativa e, a partir de 2005, assumiu o cargo de diretora de escola na Emef da escola-campo.

Como fonte para a análise financeira, foram coletados dados em instrumento preenchido conforme as informações presentes nas prestações de contas das três escolas, que são compostas por formulários próprios do PTRF, extratos bancários e comprovantes da realização das despesas, por exemplo, notas fiscais, recibos etc..

As fontes documentais foram as atas tanto dos Conselhos de Escola como das APMs e os projetos políticos pedagógicos. Os documentos foram analisados e sistematizados em instrumentos elaborados pela pesquisa. Por se tratar de documentos que não podem ser retirados das escolas, a fim de proporcionar a leitura e análise mais detalhada desses documentos optou-se por escanear ou fotografar as atas, conforme exemplo no Anexo B.

Para permitir melhor compreensão da interferência do PTRF no cotidiano escolar, buscou-se estabelecer diálogo entre as fontes de informação, como procedimento de pesquisa. Assim, as informações encontradas nos documentos são contrapostas com as entrevistas dos diferentes membros da comunidade escolar.

\subsection{As atas do CE e APM e o projeto político pedagógico das escolas}

Nas três escolas, foram recolhidas e analisadas as atas da APM e do CE, no período da pesquisa (2006-2010). Na Tabela 7, estão registrados os números de reuniões das APM e dos $\mathrm{CE}$ e o número de reuniões que foram realizadas de forma conjunta. 
Tabela 7 - Número de reuniões dos CEs e APMs (2006-2010)

\begin{tabular}{c|ccc|ccc|ccc}
\hline & \multicolumn{4}{|c|}{ CEI } & \multicolumn{3}{c|}{ EMEI } & \multicolumn{3}{c}{ EMEF } \\
& $\begin{array}{c}\text { Reuniões } \\
\text { CE }\end{array}$ & $\begin{array}{c}\text { Reuniões } \\
\text { APM }\end{array}$ & $\begin{array}{c}\text { Reuniões } \\
\text { conjuntas }\end{array}$ & $\begin{array}{c}\text { Reuniões } \\
\text { CE }\end{array}$ & $\begin{array}{c}\text { Reuniões } \\
\text { APM }\end{array}$ & $\begin{array}{c}\text { Reuniões } \\
\text { conjuntas }\end{array}$ & $\begin{array}{c}\text { Reuniões } \\
\text { CE }\end{array}$ & $\begin{array}{c}\text { Reuniões } \\
\text { APM }\end{array}$ & $\begin{array}{c}\text { Reuniões } \\
\text { conjuntas }\end{array}$ \\
\hline 2006 & 7 & 4 & 1 & 13 & 16 & 11 & 12 & 11 & 7 \\
2007 & 3 & 8 & 0 & 13 & 10 & 9 & 13 & 10 & 3 \\
2008 & 3 & 7 & 0 & 8 & 9 & 5 & 10 & 10 & 4 \\
2009 & 11 & 5 & 0 & 11 & 13 & 8 & 10 & 8 & 5 \\
2010 & 11 & 5 & 1 & 13 & 11 & 10 & 9 & $\mathbf{8}$ & 6 \\
Total & $\mathbf{3 5}$ & $\mathbf{2 9}$ & $\mathbf{2}$ & $\mathbf{5 8}$ & $\mathbf{5 9}$ & $\mathbf{4 3}$ & $\mathbf{5 4}$ & $\mathbf{4 7}$ & $\mathbf{2 5}$ \\
\hline
\end{tabular}

Fonte: Elaborada pelo autor, com base nas atas de CEs e APMs.

Nota-se que a Emei teve um número elevado de reuniões em alguns anos, com mais de uma reunião por mês. O CEI realizou menos reuniões no período, contudo, pelo fato de quase não realizar reuniões conjuntas, o número é expressivo, sendo que o ano em que realizou menos foi 2008, com dez reuniões no total.

Pelos dados levantados, a Emei foi a escola que mais realizou reuniões conjuntas, num total de 11. A diretora da Emei justifica: "Faço reunião conjunta. No mesmo dia eu faço as duas, por quê? Uma cuida basicamente da formalização da prestação de contas, o outro delibera sobre a destinação de recursos. Então, já faz tudo de uma vez só." Essa saída minimiza a questão de sobrepor atribuições da APM com as do CE, ponto que já se chamou a atenção no Capítulo 3. A Emef, ao longo do período analisado, foi reduzindo o número de reuniões tanto do CE como da APM, sendo que o ano de 2006 registrou o maior número de reuniões conjuntas, ao passo que, em 2007, foram apenas três; contudo, nos anos seguintes, há um aumento, chegando a seis no ano de 2010.

$\mathrm{Na}$ Tabela 8, estão registradas as reuniões que tiveram na pauta alguma questão relacionada ao PTRF.

Tabela 8 - Número de reuniões dos CEs e APMs que trataram do PTRF (2006-2010)

\begin{tabular}{|c|c|c|c|c|c|c|c|c|c|}
\hline & \multicolumn{3}{|c|}{ CEI } & \multicolumn{3}{|c|}{ EMEI } & \multicolumn{3}{|c|}{ EMEF } \\
\hline & $\begin{array}{c}\text { Reuniões } \\
\text { CE }\end{array}$ & $\begin{array}{c}\text { Reuniões } \\
\text { APM }\end{array}$ & $\begin{array}{l}\text { Reuniões } \\
\text { conjuntas }\end{array}$ & $\begin{array}{c}\text { Reuniões } \\
\text { CE }\end{array}$ & $\begin{array}{c}\text { Reuniões } \\
\text { APM }\end{array}$ & $\begin{array}{l}\text { Reuniões } \\
\text { conjuntas }\end{array}$ & $\begin{array}{c}\text { Reuniões } \\
\text { CE }\end{array}$ & $\begin{array}{c}\text { Reuniões } \\
\text { APM }\end{array}$ & $\begin{array}{l}\text { Reuniões } \\
\text { conjuntas }\end{array}$ \\
\hline 2006 & 1 & 4 & 1 & 6 & 10 & 6 & 6 & 9 & 5 \\
\hline 2007 & 0 & 7 & 0 & 6 & 7 & 5 & 5 & 8 & 2 \\
\hline 2008 & 0 & 7 & 0 & 6 & 5 & 4 & 3 & 6 & 1 \\
\hline 2009 & 1 & 3 & 0 & 7 & 10 & 6 & 4 & 6 & 4 \\
\hline 2010 & 3 & 4 & 1 & 4 & 7 & 4 & 3 & 4 & 2 \\
\hline Total & 5 & 25 & 2 & 29 & 39 & 25 & 21 & 33 & 14 \\
\hline
\end{tabular}

Fonte: Elaborada pelo autor, com base nas atas de CE e APM. 
Nos anos de análise o CEI, a Emei e a Emef realizaram 28, 43 e 40 reuniões, respectivamente, que tiveram na pauta o PTRF. No geral, as da APM foram as que mais abordaram a questão do PTRF, exceto a Emei, no ano de 2008, que teve mais reuniões do CE que trataram da questão do PTRF. Pelo número de reuniões desse tipo, infere-se que o CEI optou por deixar a cargo da APM tratar das questões do PTRF.

Ao longo do período de análise da pesquisa, a Emei foi a escola que teve mais reuniões conjuntas abordando questões do programa, somando 25. O CEI realizou apenas duas e a Emef um total de 14 reuniões.

Há de se ponderar que o fato de existir um número elevado de reuniões é interessante, porque promove espaços para a troca de informações e tomadas de decisão mais frequentes. Contudo, pelo depoimento das diretoras, das professoras e dos funcionários do quadro de apoio exige muito esforço para viabilizar as reuniões e não há indícios de que isso implique maior participação.

No tocante aos registros das atas do CE do CEI em todos os anos, apenas cinco (5) tratam do programa, ficando clara a opção por deixar a cargo da APM a gestão dos recursos financeiros. Apenas uma reunião versou sobre as prioridades, as quais estão listadas e sem justificativa, e uma reunião abordou a prestação de contas, que apresenta somente os valores dos gastos. No entanto, encontra-se registrado duas considerações relevantes sobre os recursos: a primeira é que os gastos dos recursos (não estão especificados quais) estavam a serviço do desenvolvimento das crianças e a segunda é que havia recursos do PTRF para comprar brinquedos, ou seja, trata-se de indícios da orientação para os gastos dos recursos do programa, o que se verifica, mais adiante, com a análise da execução das despesas do programa para o período analisado.

Nas atas das reuniões da APM do CEI, em relação às prestações de contas, está registrado que as contas foram apresentadas e aprovadas. Somente na reunião de abril de 2009, porém, há detalhamento dos valores do repasse, do saldo reprogramado e as despesas realizadas, inclusive discriminadas por categoria econômica. A partir dessa reunião não foram encontrados mais registros no livro ata da APM que tratassem da prestação de contas. Observou-se que os processos de prestação de contas possuíam atas, com formato padrão, fornecidas pela SME.

No que diz respeito à priorização dos recursos financeiros do PTRF, as atas da APM do CEI traziam listagens com os materiais, serviços e bens a serem adquiridos, ou 
contratados, e, na maioria dos casos, com breve justificativa da opção do item para priorização. Também foram encontradas menções à contemplação das prioridades e algumas justificativas do seu não alcance.

Em setembro de 2006, na ata da APM do CEI consta que a diretora informa que a escola não receberá os recursos do Adiantamento Bancário. Assim, a APM decide por utilizar os recursos do PTRF para a manutenção do prédio (desentupimento de vasos sanitários, reparos em divisórias, instalação de ventiladores, recolocação das tomadas). As prioridades estão enumeradas e os brinquedos pedagógicos estão listados como último item, entre cinco. Entretanto, ainda em setembro, em outra reunião da APM, foi declarado que não haveria tempo para realizar as despesas, mas foi informado que os recursos do Adiantamento Bancário seriam depositados e, portanto, seriam utilizados unicamente para a compra dos brinquedos pedagógicos. Vê-se que a vontade da escola era realizar a manutenção predial, mas se fosse necessário destinaria os recursos do PTRF para cobrir essas despesas. Em outros momentos, será observada a recorrência dessa interferência da urgência e adequações do espaço físico na decisão das prioridades dos recursos.

No caso da Emei, na maior parte das atas do CE, do período analisado, que tem na pauta os recursos financeiros não há registro da discussão e remete para a ata da APM. Em apenas oito reuniões, havia o detalhamento dos itens priorizados para o uso dos recursos financeiros do PTRF. Nas atas da APM, em sua maioria, estavam registrados o saldo anterior, valores recebidos, valores gastos e saldo a ser reprogramado. Em algumas das reuniões também foram apresentados orçamentos para a escolha do serviço ou material a ser adquirido.

Na reunião de julho de 2006, está registrado na ata da APM da Emei que mais de 95\% dos recursos desse período seria "destinado ao desenvolvimento de atividades educacionais e implementação do projeto pedagógico da escola". Contudo, segundo o orçamento apresentado, $82 \%$ dos recursos seriam utilizados para colocação de cortinas externas do tipo roll-on, que configura uma adequação do prédio para proteger as crianças das intempéries. Essa necessidade de colocar cortinas para fechar o pátio perdura por anos. Em 2010, a escola optou por ampliar o percentual de recursos com capital de $20 \%$ para $40 \%$, apontando como justificativa a necessidade de adequar o espaço do pátio com esse tipo de cortinas.

Trata-se de um problema de projeto de construção da escola, na medida em que não é possível acreditar que essa questão não poderia ser prevista anteriormente; além disso, no momento em que o problema foi constatado, a SME deveria ter buscado uma alternativa para solucioná-lo, evitando, assim, que as escolas fossem obrigadas a cobrir esse custo com os 
recursos destinados para o desenvolvimento do projeto político pedagógico e para equipar a escola. É evidente que a legislação também prevê que os recursos servirão para realizar a manutenção predial, mas o problema apresentado não é de manutenção e sim de adequação dos espaços, ou quem projetou a escola não tinha conhecimento sobre o clima brasileiro? $\mathrm{Ou}$, pior, não sabia que quem utilizaria o espaço seriam crianças?

A maioria das atas do CE da Emef remete o registro da pauta sobre o PTRF para as atas da APM. Quando a pauta previa a discussão das prioridades do programa, o registro é vago e em poucos casos tem enumerado quais são as prioridades. Nas atas da APM da Emef, de 2006 a 2008, os registros das prestações de contas apresentam informações incompletas, em algumas constam os valores recebidos, em outras não; às vezes mostra o saldo, incluindo o reprogramado, às vezes, não. Essas lacunas são superadas a partir de 2009, quando os registros passam a detalhar os saldos anteriores, os valores recebidos, os valores realizados e o saldo final. Nas atas das reuniões de prioridades, de 2009 e 2010, apresentam-se os valores disponíveis. É importante notar que o fato de estarem presentes os recursos disponíveis para a discussão das prioridades é fundamental, pois é muito diferente estabelecer as prioridades de quem dispõe de um dado valor e de quem dispõe de 1000 vezes esses esse valor. Ter essas informações possibilita à comunidade escolar fazer suas escolhas e tomar as decisões de forma mais segura e com mais opções de realizar o seu planejamento, além de conseguir ajustar da melhor forma possível suas necessidades com suas possibilidades.

Assim como a Emei, a Emef, em 2010, opta por ampliar o percentual de recursos com capital de $20 \%$ para $30 \%$, apontando como justificativa a necessidade de adequar o espaço do pátio com cortinas do tipo roll-on para proteger os alunos das intempéries. Novamente, observa-se o problema do projeto arquitetônico da escola.

Além das atas que trataram especificamente do PTRF, a do CE da Emei, de julho de 2006, constou o registro de uma dinâmica de sensibilização para a responsabilidade dos participantes do CE e APM. Foram estabelecidos eixos de formação: gestão democrática, abordando conceitos de gestão, democracia e participação; limites e regras; e função social do CEU. Estabeleceu-se que essas formações seriam realizadas no horário das reuniões ordinárias. Na reunião de setembro de 2006, os membros (não estão especificados quais) apresentaram as informações que levantaram sobre o tema Participação. Não há detalhamento da discussão, mas tem os subitens que foram discutidos: participação ativa, passiva, 
conquistada, consentida; e tríade da participação, fazer parte, ter parte e tomar parte. Esses foram os únicos registros sobre formação dos conselheiros.

A formação dos conselheiros é um aspecto importante relacionado a uma das condições essenciais que Bobbio (2009) julga necessário para uma definição mínima de democracia, isto é, condições reais para decidir. A rede de ensino do Município de São Paulo tem pouquíssimos mecanismos de fomentar a formação dos conselheiros e, no geral, são direcionadas aos servidores, segmento da comunidade escolar que até por conta das suas atribuições de ofício já estão mais habituados a alguns tipos de discussões e trâmites processuais. Há a necessidade de se abrir essa discussão entre a comunidade escolar e criar mecanismos e espaços de formação para conselheiros, com o intuito de efetivar as condições para o controle social das atividades das escolas e do poder público de forma geral.

Outro aspecto importante da análise são os projetos político pedagógicos das escolas. Ferreira (2000) ressalta que o processo de construção do projeto político pedagógico é importante para efetivação da gestão democrática nas escolas. Luz (2000) considera o processo de construção coletiva do projeto político pedagógico um dos três elementos fundamentais para o princípio da gestão democrática.

Embora, o projeto político pedagógico seja o conjunto das ações desenvolvidas por cada escola, revelando sua concepção de educação, de sociedade e de função social da escola, exprimindo também suas contradições, o que se analisa aqui é apenas o registro, que fornece alguns indícios de como esse processo ocorre, mesmo não sendo capaz de expressar toda sua riqueza e complexidade. Além disso, o exame será focado no PTRF e, para auxiliar, procurase estabelecer um diálogo com as entrevistas realizadas.

O projeto político pedagógico do CEI é intitulado A Criança e a Descoberta do Mundo. À pesquisa foi fornecido um documento sucinto de apenas duas páginas, com breve introdução, objetivos, plano de ação e participantes, o qual sintetiza a concepção de infância e do trabalho pedagógico da seguinte forma:

PROPOSTA PEDAGÓGICA: significar a educação das crianças, respeitando sua organização própria e ao mesmo tempo dialogando com o planejamento de suas atividades, seus diferentes ritmos e necessidades, levando em conta suas histórias de vida e suas vivências. Para os educadores, pensar as relações entre infância e cultura abre um importante campo de reflexão.

Sabemos que o desenvolvimento integral das crianças ocorre através das interações sociais, que garantem o brincar com os companheiros, investigar o meio para instigar sua curiosidade, aprender a cuidar de si, do outro e do ambiente, apreciar e apropriar-se das múltiplas linguagens que fazem parte de sua realidade, bem como ampliar o acesso às diversas manifestações culturais, de modo a construir sua própria cultura de infância. 
O documento não revela explicitamente a existência, a utilização ou a necessidade de recursos financeiros para a implementação do projeto político pedagógico da escola. Para contribuir com a análise, foi perguntado à diretora do CEI: o projeto político pedagógico da escola explicita as necessidades de recursos financeiros para se viabilizar?

\begin{abstract}
Na realidade, o projeto político da unidade na Educação Infantil acaba sendo muito amplo e difícil de ser compreendido até pelo contador, pelo pessoal da diretoria. O projeto fala das habilidades de uma forma muito generalizada. A criança precisa brincar, a criança precisa aprender ludicamente. A gente acaba tentando enfiar no projeto político da escola todas as coisas que vão sustentar e fazer com que a criança tenha autonomia. Então, como eu podia dizer para você? Ele acaba vinculado a partir do momento que se tem uma visão do que é necessário para a Educação Infantil, que é uma idade específica.

[...] Ele aprende e brinca ao mesmo tempo, então é brincando que se aprende e é aprendendo que se brinca. Está tudo incluso nesse projeto. Tem que ter uma visão muito aberta para quem lê um projeto político da Educação Infantil. Não vai colocar lá: recurso para informática, recurso para isso. Não, é recurso para que ele adquira autonomia, que ele seja cidadão, é a busca do protagonismo da infância. E esse protagonismo da infância acaba te abrindo um leque de possibilidades e infinitos recursos para serem adquiridos com isso.
\end{abstract}

Concordando com a concepção de que as crianças aprendem brincando, tanto a diretora como a professora do CEI disseram que a maior demanda da escola é a compra e manutenção de brinquedos - a verificação dessa relação entre a concepção apresentada no documento com as despesas realizadas será apresentada no item de análise das prestações de conta do CEI.

Em relação ao projeto político pedagógico da Emei, à pesquisa foi concedido o Plano Anual da escola. O projeto pedagógico, como é chamado no documento da Emei, está contido no Plano Anual, que se intitula "Infância e Cidadania: Buscando um Mundo Melhor". O projeto pedagógico define:

A criança é um sujeito social e histórico e faz parte de uma organização familiar que está inscrita em uma sociedade, com uma determinada cultura em um momento histórico. É profundamente marcada pelo meio social em que se desenvolve, mas também o marca como produtora de cultura.

É interessante observar o reconhecimento da criança como sujeito e sua relação com o meio social ao qual faz parte. Contudo, não há formas de envolver as crianças nas tomadas de decisão. No documento, está registrado que a participação se dá por meio dos representantes dos segmentos no Conselho de Escola. A diretora da Emei reconhece que não possuem formas de participação das crianças, mas reconhece a necessidade e até menciona uma experiência que ela tem conhecimento. 
Em pesquisa pioneira sobre consulta da qualidade da Educação Infantil, realizada em quatro Estados brasileiros, Cruz e Campos discorrem sobre importância de envolver as crianças e considerar suas opiniões sobre as realidades vividas nas instituições.

\begin{abstract}
A escuta das opiniões das crianças que frequentam creches e pré-escolas foi incluída nesta Consulta como estratégia fundamental para ampliar o repertório relativo ao direito e à qualidade da educação infantil, considerando pontos de vista que geralmente são excluídos do processo de discussão sobre políticas e práticas educacionais. Nos últimos anos, vem sendo construída a ideia da criança competente, com possibilidades antes insuspeitas de trocas interindividuais, de levantar hipóteses explicativas, de estabelecer relações entre fatos, de se comunicar. [...] As informações que as crianças podem oferecer são relevantes não apenas para se conhecer melhor o que se passa nas instituições que deveriam acolher todas as crianças, cuidando-as e educando-as com respeito, mas também para entender como elas veem, como se sentem, o que temem e o que desejam na sua experiência educativa. Isso é fundamental para que a creche e a pré-escola sejam espaços de enriquecimento, de desenvolvimento e de prazer para todas as crianças. (CRUZ, 2006, p. 67, grifo nosso)
\end{abstract}

Outro elemento importante, presente no Plano Anual, diz respeito aos recursos financeiros para a implementação do projeto pedagógico da escola. No documento, estão previstos os recursos próprios gerados por contribuição dos pais em campanhas e festas promovidas pela escola, os recursos do adiantamento bancário e os recursos do PTRF. Entretanto, não há detalhamento de como os recursos podem ser usados para implementar o projeto pedagógico da escola.

Perguntou-se à diretora da Emei se o projeto político pedagógico explicita as necessidades de recursos financeiros para sua viabilização? Ela responde que:

Não explicita. Não. O que nós temos é assim, o que nós queremos é um espaço para o melhor atendimento possível para a criança. E aí, vamos prover aquilo que é necessário. Eu acho que está implícito, mas de maneira explícita não está.

Assim, foi questionado também quais seriam as principais demandas do projeto político pedagógico para a utilização desses recursos financeiros?

Se a gente pensar que desde 2005, que eu estou aqui, a primeira questão, o projeto pedagógico que a gente foi construindo, focava no quê? No protagonismo infantil, no espaço voltado para que as crianças sejam felizes. Existe um estudo de realidade local que nós fazemos permanentemente e que explicita que as nossas crianças moram em cubículos, palafitas em cima de rios, não tem espaço para brincadeira. $\mathrm{O}$ espaço para essa criança brincar é aqui na Emei. Tendo isso, claro, o que acontece? $\mathrm{O}$ espaço da escola tem que ser um espaço rico em oportunidades formativas, um ambiente rico, estimulante. Então, isso, é claro, para toda a equipe. Isso é o cerne do projeto pedagógico. 
Então, quais são os espaços de atividades lúdicas que temos? Não tínhamos nenhum. Então, playground, prioridade, vamos montar o playground. Montado o playground, o centro recreativo? O centro recreativo. Salas de aula precisam também de ambiência? Então, composição. Percebe? Então vai sempre girando em função disso. - E, agora, o que a nossa criança precisa, o que está faltando para o melhor atendimento das nossas crianças?

A professora da Emei também concorda que a maior demanda é material para as salas de aula, em especial brinquedos, fantasias, entre outros. A diretora, porém, revela que há também outras demandas para os recursos.

\begin{abstract}
Desde agosto do ano passado, há a chamada gestão mista da merenda. A Secretaria Municipal de Educação, através do abastecimento, encaminha os gêneros alimentícios e existe uma empresa terceirizada que responde só pela preparação dos alimentos. Então, a escola passou a ter uma maior gestão sobre a montagem do cardápio e tudo o mais. - Então, o que está faltando para a gente melhorar a qualidade dessa merenda? A gente pode estar comprando um moedor de carne industrial para dar conta. Aí, a gente oferece a carne que vem para essa merenda para a criança não só picadinha, como é feito regularmente, mas pode fazer moída, que vai ter uma maior aceitação. Mas é sempre assim: - O que é melhor para a criança, o que a gente pode fazer para eles? É sempre assim que é pensada a coisa.
\end{abstract}

Por um lado, é interessante que as escolas tenham condições de melhorar as refeições fornecidas para as crianças, mas, por outro, novamente, os recursos do PTRF acabam cobrindo despesas que não estão diretamente relacionadas ao desenvolvimento de atividades pedagógicas. Lembrando que a merenda não está entre os gastos considerados como manutenção e desenvolvimento do ensino (LDB/96), inclusive há os recursos específicos para esse fim previstos no orçamento da prefeitura.

Quanto ao projeto político pedagógico da Emef, o documento fornecido à pesquisa se intitula "Identidade e Cidadania: Formando Protagonistas". Trata-se de um registro extenso, com descrição das atividades realizadas pela escola em anos anteriores e o processo de construção do projeto político pedagógico. A concepção apresentada expressa a relevância da contextualização do espaço social ao qual a comunidade escolar se insere e o incentivo e reconhecimento dessas pessoas como sujeitos desse contexto social.

No contexto socioambiental investigado, foram selecionados temas significativos para a comunidade escolar e que foram considerados no planejamento de alguns professores para as ações diagnósticas e organização de sequências didáticas no decorrer do ano letivo. Nos horários coletivos foi necessária uma reelaboração do Plano Especial de Ação para a construção de uma proposta metodológica investigativa com o objetivo de desenvolver a práxis cidadã para o sujeito se identificar como agente nesse processo. E, desse modo, possibilitar o desenvolvimento de atitudes de respeito, tolerância e inclusão e das diversas formas 
de expressão e escrita, vinculada ao contexto local e global do aluno, uma vez que a percepção, compreensão, reflexão e ação são fundamentais para a organização do pensamento e apropriação de conhecimentos significativos, necessários ao ato protagonista.

No projeto político pedagógico da escola, não há menção aos recursos do PTRF, nem de outras fontes. Contraditoriamente, ao questionar a diretora da Emef se o projeto explicitava a necessidade de recursos financeiros, ela responde:

Coloco, coloca sim. Para cada ação, qual o investimento que a gente vai fazer. Para a rádio, para o projeto cinema, para a festa poética, para as avaliações conjuntas que a gente faz interdisciplinares vai também, há um investimento nisso de xerox, de papel, de tudo. A gente estima tudo, a gente coloca isso, sim.

Da mesma forma, a professora da Emef também afirma que está previsto o uso dos recursos.

Explicita. Sempre. Porque dentro do projeto político pedagógico tem os projetos, a dinâmica dos projetos que envolvem material específico da área. De geografia, por exemplo, o pessoal pede muito para comprar bússola. Tem sempre um material diferenciado, que a verba propicia isso. Porque ela é toda voltada para o aluno. Tudo que é benefício para o aluno, então ela faz parte.

Parece que há uma naturalização da necessidade de recursos financeiros para desenvolver as atividades, mas isso não consta nos registros. De certa forma, complica a realização do planejamento da realização das despesas e, por consequência, assume-se uma dinâmica reativa às demandas cotidianas, atendendo de acordo com o surgimento.

Outra possível justificativa para essa dinâmica, pode estar no fato de existir certa regularidade nas necessidades. Por exemplo, a diretora da Emef apresenta como maior demanda para os recursos financeiros as despesas com "papelaria, equipamento eletroeletrônico, muitas vezes. Adequação de espaços para isso. A gente está fazendo uma brinquedoteca". 


\subsection{Análise dos recursos financeiros e gastos do PTRF das escolas}

Nesta parte do texto, analisam-se os recursos financeiros recebidos pelas três escolas do programa, bem como as despesas realizadas no período de 2006 a 2010. A análise, primeiramente, será detida em cada escola, para, posteriormente, encerrar com algumas comparações entre elas.

Os dados orçamentários foram retirados das prestações de contas em instrumento elaborado pelo "Projeto de Pesquisa Gestão Financeira Escolar como Política Pública: análise de procedimentos legais e administrativos, processos participativos e montantes dos recursos financeiros destinados às escolas de redes públicas”.

As prestações de contas apresentavam, em formulário próprio, o detalhamento das receitas e despesas por repasse, bens adquiridos e ata de aprovação de contas. Os dados presentes nos formulários próprios foram confrontados com as notas fiscais e extratos bancários disponibilizados pelas escolas. Para garantir a comparabilidade dos dados levantados, os valores foram deflacionados para dezembro de 2010, pelo INPC (IBGE).

Com o intuito de aprofundar a análise, as despesas foram classificadas em pedagógicas e não pedagógicas. Para esta pesquisa, foram determinadas como despesas pedagógicas aquelas realizadas para uso no trabalho pedagógico diretamente com os alunos (expediente pedagógico, que seriam os materiais de papelaria de uso cotidiano e coletivo, equipamentos, brinquedos, transporte para estudo do meio, material esportivo etc.). Como não pedagógico, foram consideradas todas as despesas com serviços e material de manutenção predial, adequação dos espaços, taxas e tarifas, serviços contábeis, expediente de secretaria, entre outros.

\subsubsection{Recursos financeiros e gastos do PTRF do CEI}

No período estabelecido para análise desta pesquisa, o CEI recebeu o montante de R \$ 73.547,54. Para o cálculo dos repasses, foi considerado o número de 296, 297, 297, 295 e 280 matrículas para os anos de 2006, 2007, 2008, 2009 e 2010, respectivamente. Portanto, o CEI 
recebeu os montantes totais e os distribuídos, por ano e categoria econômica, registrados na Tabela 9.

Tabela 9 - Recursos financeiros recebidos do PTRF pelo CEI, por ano (em R\$)

\begin{tabular}{lcrrrrr}
\hline Ano & $\mathbf{2 0 0 6}$ & $\mathbf{2 0 0 7}$ & $\mathbf{2 0 0 8}$ & $\mathbf{2 0 0 9}$ & $\mathbf{2 0 1 0}$ & Total \\
\hline Custeio (R\$) & $8.189,75$ & $12.573,35$ & $11.741,71$ & $15.107,17$ & $12.864,00$ & $60.475,98$ \\
Capital (R\$) & - & $3.143,34$ & $2.935,43$ & $3.776,79$ & $3.216,00$ & $13.071,56$ \\
Total (R\$) & $8.189,75$ & $15.716,69$ & $14.677,13$ & $18.883,96$ & $16.080,00$ & $73.547,54$ \\
\% para custeio & 100 & 80 & 80 & 80 & 80 & 82 \\
\% para capital & 0 & 20 & 20 & 20 & 20 & 18 \\
\hline
\end{tabular}

Fonte: Elaborada pelo autor, com base nos dados levantados na pesquisa de campo. Valores deflacionados para 12/2010, pelo INPC (IBGE).

Em 2006, o CEI recebeu menos recursos financeiros por conta da demora em regularizar sua APM e a documentação exigida para recebê-los. Entretanto, possuía um saldo reprogramado do ano anterior de $\mathrm{R} \$ 4.073,57$. Em 2009, o CEI recebeu o maior montante de recursos, mesmo não sendo o ano com o maior número de matrículas, nem com maior valor nos critérios de cálculo. Isso se deve ao fato de a escola ter recebido também os recursos adicionais, neste ano, por economia de água e energia elétrica.

A Tabela 10 registra as despesas realizadas pela escola nos anos analisados.

Tabela 10 - Despesas realizadas com recursos do PTRF pelo CEI, por ano (em R\$ e \%)

\begin{tabular}{lrrrrrr}
\hline Ano & $\mathbf{2 0 0 6}$ & $\mathbf{2 0 0 7}$ & $\mathbf{2 0 0 8}$ & $\mathbf{2 0 0 9}$ & $\mathbf{2 0 1 0}$ & Total \\
\hline Despesas em Custeio (R\$) & $4.057,85$ & $6.328,07$ & $19.755,00$ & $15.233,54$ & $12.081,28$ & $57.455,73$ \\
Despesas em Capital (R\$) & - & - & 330,16 & $3.399,12$ & 358,80 & $4.088,08$ \\
Total(R\$) & $4.057,85$ & $6.328,07$ & $20.085,17$ & $18.632,66$ & $12.440,08$ & $61.543,82$ \\
\% de custeio & 100 & 100 & 98 & 82 & 97 & 93 \\
\% de capital & 0 & 0 & 2 & 18 & 3 & 7 \\
\hline
\end{tabular}

Fonte: Elaborada pelo autor, com base nos dados levantados na pesquisa de campo. Valores deflacionados para 12/2010 pelo INPC (IBGE).

Em termos de montantes, a escola realizou seus gastos, predominantemente, na categoria de custeio. Do total de receitas disponíveis no período, $\mathrm{R} \$ 13.071,56$, para despesas com capital apenas $\mathrm{R} \$ 4.088,08$ foram gastos, ou seja, apenas 31\%. Somente em 2009, a escola realizou $18 \%$ das despesas com capital, valor próximo ao destinado nesse ano. O Gráfico 5 compara os recursos financeiros recebidos e os realizados pela escola, bem como o saldo reprogramado. As despesas em custeio, a partir de 2006, foram crescendo até 2008, quando atinge o maior valor, aproximadamente $\mathrm{R} \$ 20$ mil. Nos anos seguintes, as despesas diminuem para cerca de R\$15 mil, em 2009, e R\$ 12 mil, em 2010. 
Gráfico 5 - Receita, gasto e saldo reprogramado dos recursos do PTRF do CEI por ano (em $\mathrm{R} \$)$

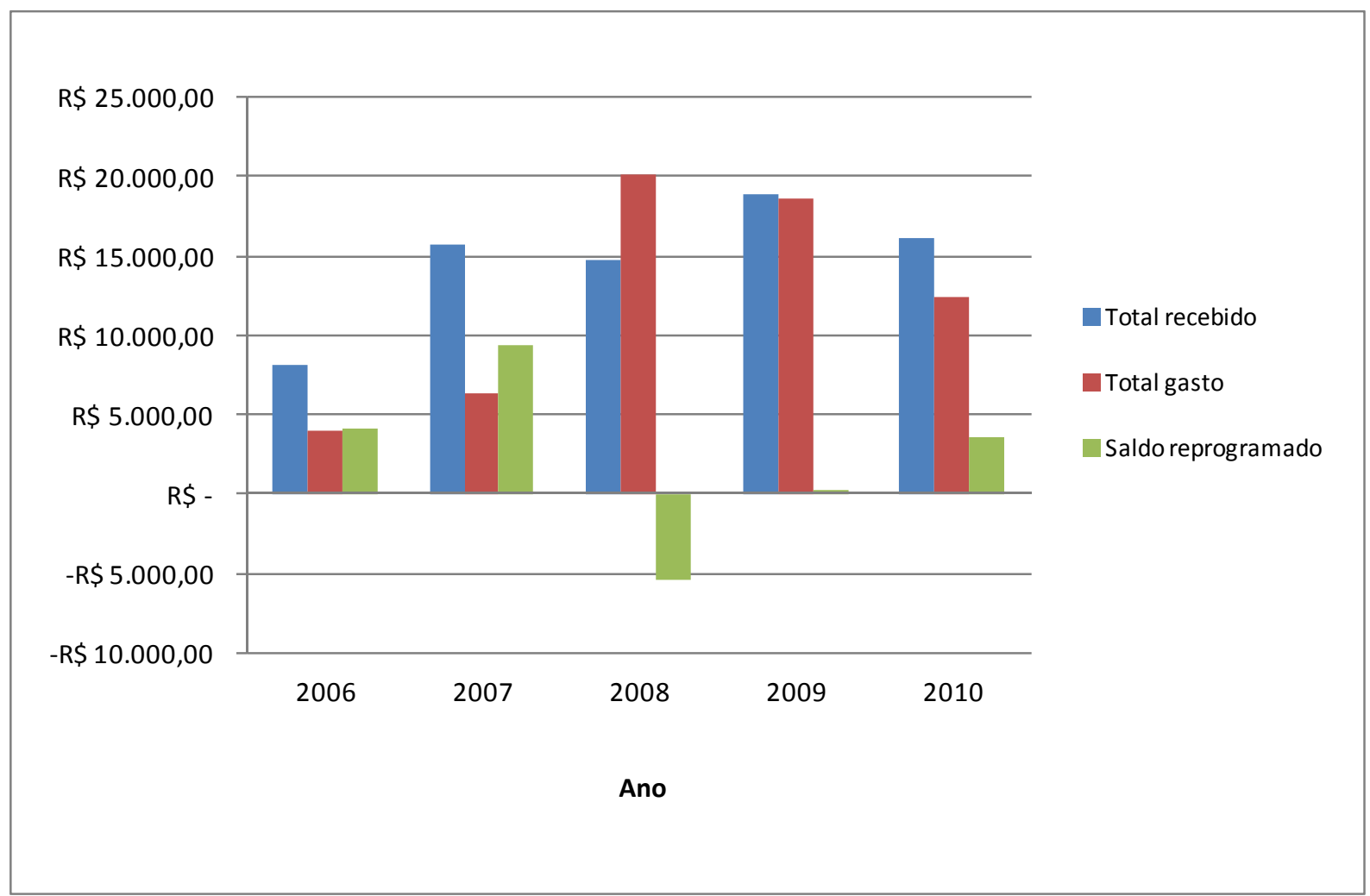

Fonte: Elaborado pelo autor, com base nos dados levantados na pesquisa de campo. Valores deflacionados para 12/2010 pelo INPC (IBGE).

No ano de 2006, além dos recursos repassados para o ano havia o saldo de R\$ 4.073,57, de 2005, que foi reprogramado para o ano. Consta em ata da APM que os recursos foram recebidos, mas não houve tempo hábil para a realização das despesas. Observando o Gráfico 5, é possível notar que, em 2009, o CEI gastou praticamente todo o recurso recebido, mas, em 2006, 2007 e 2010, houve recursos que não foram gastos e reprogramados para os anos seguintes. O ano de 2008 foi o único que excedeu os recursos recebidos para o ano, tendo, assim, que utilizar dos recursos reprogramados do ano anterior. Dos $\mathrm{R} \$ 73.547,54$ disponíveis para realizar despesas no período de análise da pesquisa, $\mathrm{R} \$ 61.543,82$ foram gastos, restando um saldo reprogramado de $\mathrm{R} \$ 12.003,72$. Esse valor é significativo, pois representa cerca de $16 \%$ dos recursos disponibilizados para o período de análise da pesquisa, ou cerca de $74 \%$ dos recursos recebidos pela escola para o ano de 2010.

A diretora do CEI ressalta a dificuldade de atender as necessidades da escola com os procedimentos de utilização dos recursos do PTRF. 
[...] Porque a gente não tem a liberdade de gastar o recurso exatamente como a gente necessita. Vou dar um exemplo simples: se a DRE fez uma compra de cadernos, é um exemplo bem simples, e lá está escrito que comprou caderno brochura, tal. Se ela comprou, deve ter comprado cem cadernos e isso não vai dar para distribuir para toda a diretoria. Mas eu aqui preciso desses cadernos também e eles não têm como me fornecer, eu tenho que primeiro verificar se eu vou poder comprar, geralmente eu não posso comprar, porque a DRE já efetuou essa compra, então, eu fíco amarrada, não posso gastar dinheiro com caderno [...].

A diretora do CEI reconhece que a questão é complexa, mas aponta os limites desse procedimento e suas implicações para a escola.

São coisas que parecem pequenas, mas quando você vai ver, acaba limitado a uma série de compras. Eu entendo que o ideal seria a gente ter o recurso e ter liberdade de utilização com as devidas prestações de contas. Se eu preciso comprar uma garrafa térmica, eu vou lá, compro a garrafa térmica e mostro a nota da garrafa térmica. Mas por conta de toda a burocracia e talvez de tantos problemas que enfrentem quando se tem recursos na mão de terceiros, eles acabam limitando tanto que a gente acaba muito amarrada.

Então, às vezes, a não utilização dos recursos são exemplos de dificuldades de conciliar os procedimentos estabelecidos pelo programa e as necessidades reais das escolas.

Observam-se, no Gráfico 6, os gastos realizados por tipo de despesa. As despesas foram classificadas em material de consumo, material permanente, serviços de terceiros e tarifas, taxas, etc.

Gráfico 6 - Montantes de recursos gastos do PTRF por tipo de despesa no CEI, por ano (em $\mathrm{R} \$)$

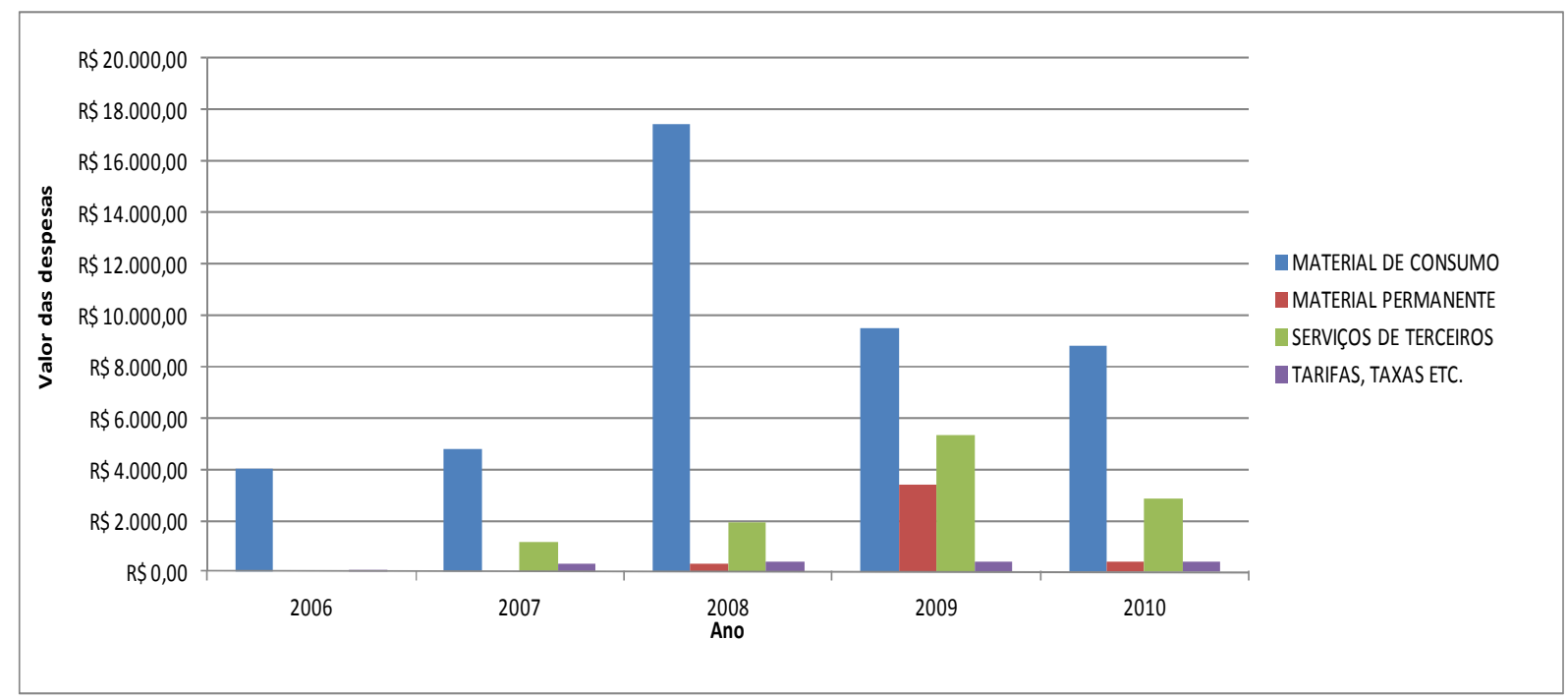

Fonte: Elaborado pelo autor, com base nos dados levantados na pesquisa de campo. Valores deflacionados para 12/2010, pelo INPC (IBGE). 
Em todos os anos, o tipo de despesa que proporcionou o maior gasto foi material de consumo. No decorrer do período, a despesa em serviços de terceiros também passa a ser significativa, em 2009, com mais de R 5 mil. No mesmo ano, os gastos realizados na compra de material permanente foram de aproximadamente $\mathrm{R} \$ 3,5$ mil.

No Gráfico 7, as despesas realizadas por tipo estão em percentual do total gasto por ano.

Gráfico 7 - Recursos gastos do PTRF por tipo de despesa do CEI, por ano (em \%)

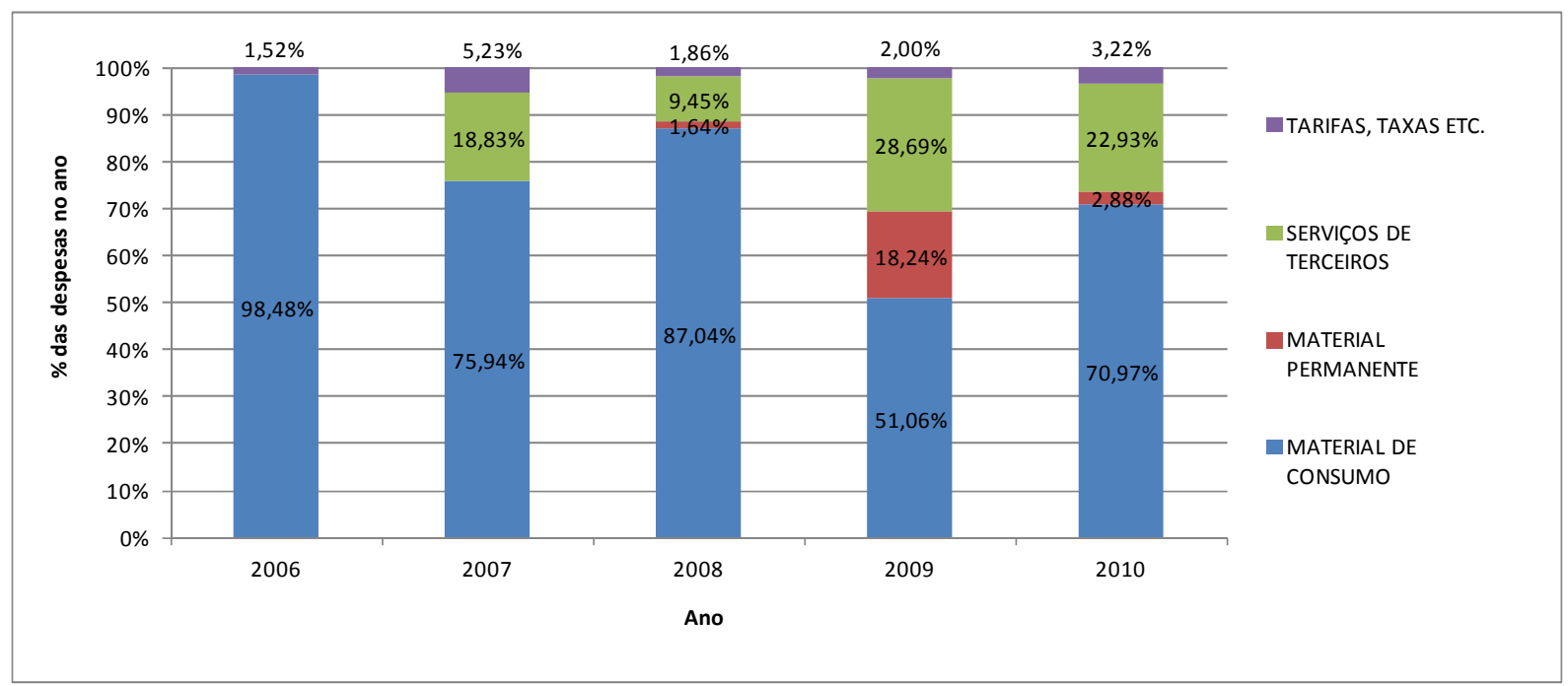

Fonte: Elaborado pelo autor, com base nos dados levantados na pesquisa de campo. Valores deflacionados para 12/2010, pelo INPC (IBGE).

Como se nota, as despesas em material de consumo configuram o maior percentual. Contudo, apresentou certa variação no período, devido ao crescimento de outras despesas como os serviços de terceiros, que, em 2009, chegou a representar cerca de 30\% das despesas e da aquisição de material permanente, que, no mesmo ano, chegou a aproximadamente $20 \%$.

No ano de 2010, observa-se que os recursos gastos em material permanente compreenderam cerca de $3 \%$ do total das despesas realizadas, não chegaram a $10 \%$ do valor disponível para essa categoria econômica nesse ano. Nas atas de APM, está registrado que a escola não quis alterar o percentual das despesas para capital e custeio. Segundo a diretora do CEI, a maior demanda para os recursos financeiros do PTRF “é brinquedo. [...] Eu acho que é isso, são os recursos mais relacionados à Educação Infantil, faixa etária até 4 anos, que são brinquedos, as motocas, as bonecas, os carrinhos." Ao questionar uma mãe do CEI, se a 
escola tem muitas despesas em manutenção, ela respondeu que sim e completa afirmando que a unidade sempre conserta o que está quebrado o mais rápido possível para que as crianças não sejam prejudicadas.

Tanto a professora do CEI como a funcionária do CEI entrevistadas concordam que a maior demanda é com brinquedos e manutenção, no caso, na categoria econômica de custeio, embora a escola não tenha optado por alterar os percentuais de recursos destinados para custeio e capital. Pela análise dos gastos realizados e os depoimentos, essa flexibilidade implementada a partir de 2010 no programa é muito importante, pois proporciona mais liberdade para as escolas adequarem os recursos às suas necessidades.

O Quadro 5 explicita as despesas realizadas no período de análise, classificando-as em pedagógicas e não pedagógicas. As despesas com o pedagógico foram: brinquedos pedagógicos, livros, expediente pedagógico (material de papelaria de uso direto com os alunos) e compra e manutenção de equipamento de uso direto com os alunos. E as despesas com o não pedagógico referem-se a: taxas e tarifas, manutenção e adequação do espaço físico, material de expediente para secretaria e serviço contábil. 
Quadro 5- Despesas em pedagógico e não pedagógico com recursos do PTRF do CEI, por ano (em R\$ e \%)

\begin{tabular}{|c|c|c|c|c|}
\hline Ano & Classificação & Descrição & Despesa & $\%$ \\
\hline \multirow{3}{*}{2006} & Pedagógico & Brinquedos pedagógicos. & $R \$ 3.996,29$ & $98,48 \%$ \\
\hline & Não pedagógico & Tarifa de manutenção de conta bancária e CPMF. & $\mathrm{R} \$ 61,56$ & $1,52 \%$ \\
\hline & & Total & $\mathrm{R} \$ 4.057,85$ & $100 \%$ \\
\hline \multirow{3}{*}{2007} & Pedagógico & $\begin{array}{l}\text { Brinquedos pedagógicos; coleção de livros; expediente } \\
\text { pedagógico. }\end{array}$ & $\mathrm{R} \$ 4.352,75$ & $68,78 \%$ \\
\hline & Não pedagógico & $\begin{array}{l}\text { Material de primeiros socorros; conserto de armários; } \\
\text { Tarifa de manutenção de conta bancária e CPMF. }\end{array}$ & $\mathrm{R} \$ 1.975,31$ & $31,22 \%$ \\
\hline & & Total & $\mathrm{R} \$ 6.328,07$ & $100 \%$ \\
\hline \multirow{3}{*}{2008} & Pedagógico & $\begin{array}{l}\text { brinquedos pedagógicos; material de expediente } \\
\text { pedagógico; conserto de tv e som; aparelho de DVD e } \\
\text { microfone. }\end{array}$ & $\mathrm{R} \$ 11.477,99$ & $57,15 \%$ \\
\hline & Não pedagógico & $\begin{array}{l}\text { Material e instalação de divisórias e tela de proteção; } \\
\text { confecção de canaleta de drenagem; material de } \\
\text { expediente secretaria; Tarifa de manutenção de conta } \\
\text { bancária e CPMF; CCM da APM. }\end{array}$ & $\mathrm{R} \$ 8.607,18$ & $42,85 \%$ \\
\hline & & Total & $\mathrm{R} \$ 20.085,17$ & $100 \%$ \\
\hline \multirow{3}{*}{2009} & Pedagógico & $\begin{array}{l}\text { Material de expediente pedagógico, tapete de EVA, } \\
\text { brinquedos pedagógicos e aparelho de som. }\end{array}$ & $\mathrm{R} \$ 8.146,41$ & $43,72 \%$ \\
\hline & Não pedagógico & $\begin{array}{l}\text { Vidros para janelas; divisórias e instalação de divisórias; } \\
\text { tela de proteção e instalação da tela; material elétrico } \\
\text { para instalação de ventiladores; ventiladores; escada; } \\
\text { serviços contábeis; montagem do quiosque; conserto de } \\
\text { fechaduras; conserto de forno micro-ondas; } \\
\text { manutenção da conta bancária ; Taxa de Fiscalização de } \\
\text { Estabelecimento. }\end{array}$ & $\mathrm{R} \$ 10.486,25$ & $56,28 \%$ \\
\hline & & Total & $\mathrm{R} \$ 18.632,66$ & $\begin{array}{r}56, \angle 8 \% \\
100 \% \\
\end{array}$ \\
\hline \multirow{4}{*}{2010} & Pedagógico & $\begin{array}{l}\text { Material de expediente pedagógico; livros para as } \\
\text { crianças; boneco de inclusão; brinquedo pedagógico; } \\
\text { conserto de som. }\end{array}$ & $\mathrm{R} \$ 8.955,20$ & $71,99 \%$ \\
\hline & Não pedagógico & $\begin{array}{l}\text { Material de expediente para secretaria; furador e } \\
\text { encadernadora; serviços contábeis; tarifa de } \\
\text { manutenção da conta bancária; Taxa de Fiscalização de }\end{array}$ & & \\
\hline & & Estabelecimento. & $\mathrm{R} \$ 3.484,88$ & $28,01 \%$ \\
\hline & & Total & $\mathrm{R} \$ 12.440,08$ & $100 \%$ \\
\hline
\end{tabular}

Fonte: Elaborada pelo autor, com base nos dados levantados na pesquisa de campo. Valores deflacionados para 12/2010 pelo INPC (IBGE).

No ano de 2006, o CEI realizou quase o total das despesas no que se classificou como despesas em pedagógico (98\%). Esse ano, entretanto, foi o que a escola realizou o menor gasto, com R\$3.996,29. Em 2009, registra-se o menor percentual em despesas com pedagógico, apenas $44 \%$. Em termos de montantes, porém, foi o terceiro maior, com $\mathrm{R} \$$ 8.146,41. O maior montante de despesas com pedagógico ocorre em 2008, com R $\$ 11.477,99$. 
As despesas classificadas como não pedagógico assumiram uma dinâmica de crescimento no período, com exceção do último ano. O menor valor foi registrado no ano de 2006, com apenas R \$ 61,56, ao passo que o maior valor, R \$ 10.486,25, é registrado em 2009. Observa-se que, no ano de maior despesa com o não pedagógico, estão presentes serviços de adequação dos espaços físicos da escola.

O Gráfico 8 ilustra a divisão das despesas em pedagógico e não pedagógico em percentuais. Em 2006, os gastos com pedagógico chegaram quase à totalidade das despesas e, nos anos seguintes, as despesas com não pedagógico aumentou. Contudo, somente no ano de 2009 superou os $50 \%$ do total das despesas.

Gráfico 8 - Despesas pedagógicas e não pedagógicas com recursos do PTRF do CEI, por ano $(\mathrm{em} \%)$

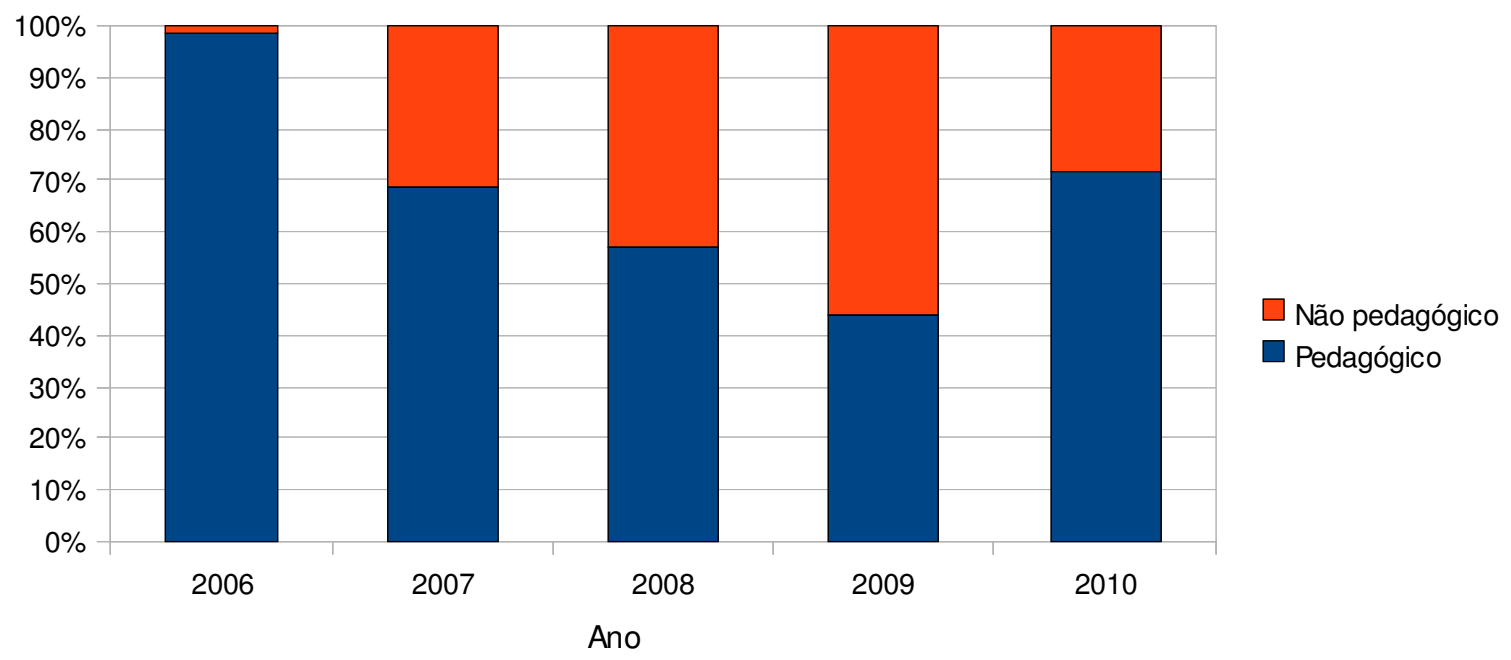

Fonte: Elaborado pelo autor, com base nos dados levantados na pesquisa de campo. Valores deflacionados para 12/2010, pelo INPC (IBGE).

O aumento dos gastos com adequação dos espaços e manutenção foi o responsável pela elevação das despesas em não pedagógico, em 2009. Quanto à manutenção, a diretora relata que:

Nós temos adiantamento bancário que é para manutenção do equipamento. Mas essa verba é de mil reais, apenas, ao mês. Então a gente tem que fazer milagres para, ao mês, conseguir consertar tudo. Porque entupimento [vasos sanitários], por exemplo, eles acontecem mais de duas vezes por mês. [...] A grande maioria [dos recursos do PTRF] é para o pedagógico. Agora, se precisa, temos que usar o PTRF, porque senão o prédio começa a deteriorar. 
Então, à medida que aumenta a necessidade de recursos para a manutenção, dada à necessidade de os recursos do PTRF cobrirem a manutenção predial, o que é bem oneroso, reduzem-se os recursos que podem ser utilizados para o trabalho pedagógico, dificultando o planejamento dos gastos e, de certa forma, condicionando as tomadas de decisões às emergências.

Outro fator para o aumento dos gastos em não pedagógico, deve-se ao fato de a construção de um quiosque ter sido incluída nesse tipo de despesas, para que as crianças pudessem brincar ou ouvir histórias em um dos pátios externos sem estarem expostas ao clima. Pode-se pensar que esse gasto deveria ter sido classificado como despesa em pedagógico, pois se trata de criar um espaço para uso direto com as crianças, com finalidade pedagógica. Entretanto, isso mascararia uma questão muito importante. Como se trata de um prédio planejado e construído com o intuito de abrigar uma escola, por que é entregue para funcionamento e atendimento à população, sem ter as condições adequadas para isso? Não estamos falando de uma rede de ensino nova que nunca fez uma escola e não conhece os seus problemas. É muito complexo deixar a cargo da escola a realização das adequações de médio e grande portes dos imóveis com o pouco recurso financeiro que administra diretamente e sem funcionários em quantidade adequada e sem conhecimento técnico.

\subsubsection{Receitas e gastos do PTRF da Emei}

Desde o primeiro ano do programa (2005), a Emei já havia firmado o Termo de Compromisso e recebeu os recursos financeiros desse ano, sendo que utilizou os recursos, restando um saldo de $\mathrm{R} \$ 37,49$, que foi reprogramado para o ano de 2006. Para o cálculo dos repasses, foram considerados os seguintes números de matrículas: 695 para o ano de 2006; 708 para 2007; 689 para 2008; 697 para 2009 e 646 para 2010.

Na sequência, a Tabela 11 explicita os recursos do programa recebidos por categoria econômica e por ano. 
Tabela 11 - Recursos financeiros recebidos do PTRF pela Emei, por ano (em R\$ e \%)

\begin{tabular}{lrrrrrr}
\hline Ano & $\mathbf{2 0 0 6}$ & $\mathbf{2 0 0 7}$ & $\mathbf{2 0 0 8}$ & $\mathbf{2 0 0 9}$ & $\mathbf{2 0 1 0}$ & Total \\
\hline Custeio (R\$) & $39.237,33$ & $32.651,82$ & $30.356,43$ & $34.306,02$ & $23.584,00$ & $160.135,59$ \\
Capital (R\$) & $2.133,64$ & $8.162,96$ & $7.589,11$ & $8.576,50$ & $11.792,00$ & $38.254,21$ \\
Total (R\$) & $41.370,97$ & $40.814,78$ & $37.945,54$ & $42.882,52$ & $35.376,00$ & $198.389,81$ \\
\% para custeio & 95 & 80 & 80 & 80 & 67 & 81 \\
\% para capital & 5 & 20 & 20 & 20 & 33 & 19 \\
\hline
\end{tabular}

Fonte: Elaborada pelo autor, com base nos dados levantados na pesquisa de campo. Valores deflacionados para 12/2010, pelo INPC (IBGE).

Nos anos analisados, a Emei foi enquadrada na segunda faixa de número de matrículas para o cálculo dos repasses (de 401 a 800 matrículas). Em 2009, recebeu o maior montante de recursos financeiros no período analisado. Assim como o CEI, esse não foi o ano em que a escola registrou o maior número de matrículas e tampouco é o período em que o programa transferiu mais recursos por matrícula. Contudo, a escola recebeu os recursos adicionais em razão da economia do consumo de água e de energia elétrica.

Em 2010, a escola optou por alterar para o $2^{\underline{0}}$ e $3^{\underline{0}}$ repasses os percentuais destinados para despesas de custeio e capital para $60 \%$ e $40 \%$, respectivamente. Pelo registro em ata do CE, de 30/11/2010, consta a deliberação sobre os percentuais de recursos para capital e custeio para $60 \%$ e $40 \%$, respectivamente. A justificativa registrada na ata foi fechar os corredores com as cortinas rollon-on (despesa que pode se caracterizar como adequação de imóvel), para evitar que as crianças ficassem expostas a ação do vento, da chuva e do frio, por razão do clima do local e as características do prédio (pátio e corredores externos abertos).

Tabela 12 - Despesas realizadas com recursos do PTRF pela Emei, por ano (em R\$ e \%)

\begin{tabular}{lrrrrrr}
\hline Ano & $\mathbf{2 0 0 6}$ & $\mathbf{2 0 0 7}$ & $\mathbf{2 0 0 8}$ & $\mathbf{2 0 0 9}$ & $\mathbf{2 0 1 0}$ & Total \\
\hline Despesas em Custeio (R\$) & $21.558,54$ & $26.750,52$ & $27.931,61$ & $40.157,57$ & $27.250,90$ & $143.649,14$ \\
Despesas em Capital (R\$) & $9.065,33$ & $4.075,76$ & $6.601,06$ & $12.559,96$ & $7.840,00$ & $40.142,11$ \\
Total(R\$) & $30.623,87$ & $30.826,28$ & $34.532,67$ & $52.717,53$ & $35.090,90$ & $183.791,25$ \\
\% de custeio & 70 & 87 & 81 & 76 & 78 & 78 \\
\% de capital & 30 & 13 & 19 & 24 & 22 & 22 \\
\hline
\end{tabular}

Fonte: Elaborada pelo autor, com base nos dados levantados na pesquisa de campo. Valores deflacionados para 12/2010, pelo INPC (IBGE).

As despesas em custeio tiveram menor montante, $\mathrm{R} \$ 21.558,54$, no ano de 2006, mesmo sendo a segunda maior transferência no período analisado. A maior realização de gastos em custeio, com o valor de $\mathrm{R} \$ 40.157,57$, ocorreu em 2009, coincidindo com o ano com maior montante de recursos transferidos para a APM da escola. 
Como destacado anteriormente, em 2006 não havia clareza na legislação sobre a execução de recursos do programa, na categoria econômica de capital e, portanto, observamos um montante menor de despesas realizadas nos gastos totais do programa. Entretanto, nesse mesmo ano, a Emei teve uma interpretação diferente e registrou $\mathrm{R} \$$ 9.065,33 em despesas de capital, mesmo a escola recebendo apenas a ordem de $\mathrm{R} \$ 2.133,64$, explicitamente para as despesas com capital. O reconhecimento dessa ambiguidade na legislação no período em questão permitiu a aprovação das contas do CEI sem maiores problemas.

Em 2009 e 2010, as despesas em capital foram superiores aos 20\% do total. Há dois fatores que permitem isso: a) por haver saldo reprogramado dos repasses de 2007 e de 2008; b) em 2010, a Emei fez opção por alterar os percentuais do $2^{\underline{0}}$ e $3^{\underline{o}}$ repasses para $40 \%$ de recursos para despesas com capital.

O Gráfico 9 compara as receitas oriundas do PTRF, as despesas realizadas e os saldos reprogramados por ano.

Gráfico 9 - Receita, gasto e saldo reprogramado dos recursos do PTRF da Emei, por ano (em $\mathrm{R} \$)$

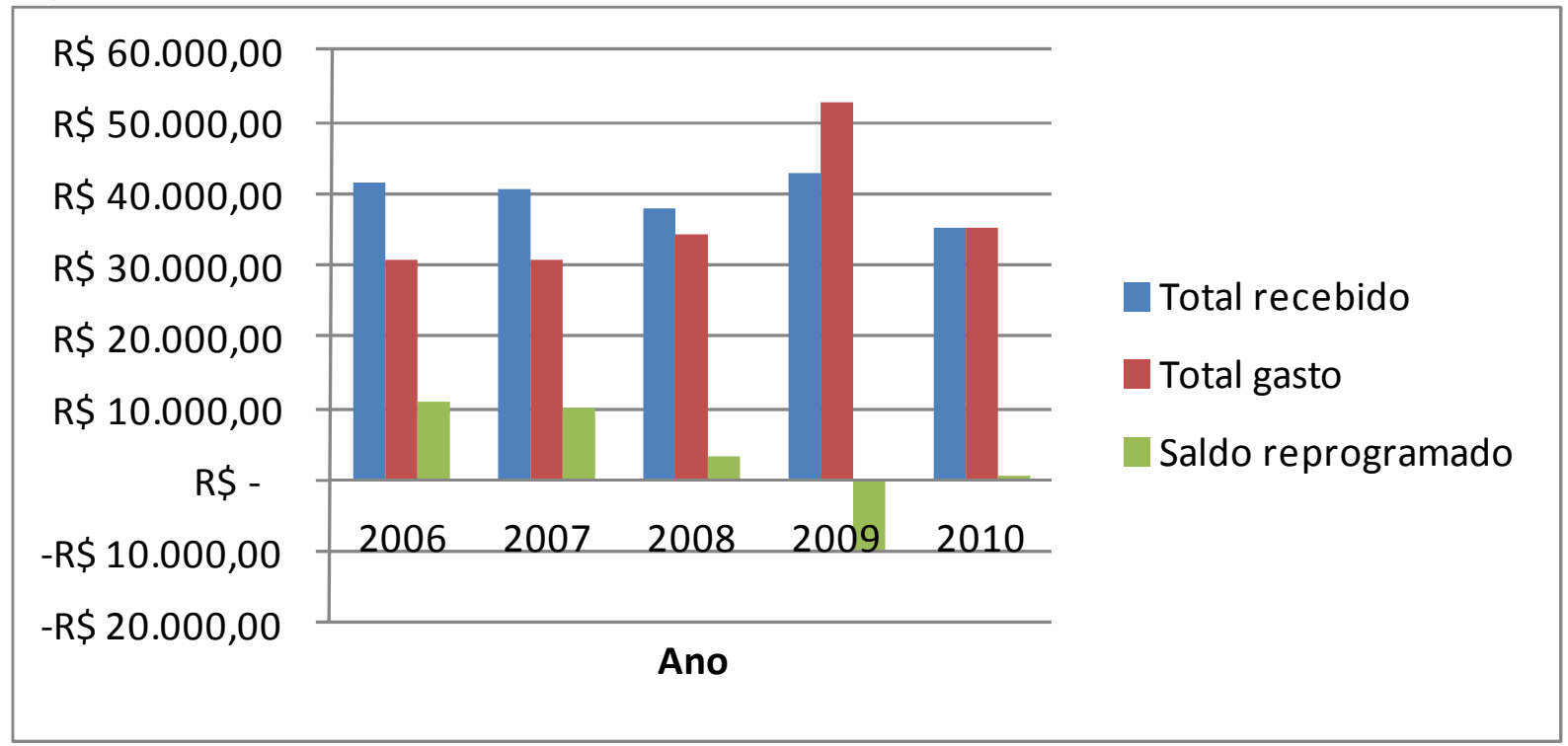

Fonte: Elaborado pelo autor, com base nos dados levantados na pesquisa de campo. Valores deflacionados para 12/2010, pelo INPC (IBGE).

Em 2006, os recursos disponibilizados contam com o saldo reprogramado de $\mathrm{R} \$ 46,82$ de 2005, além dos repasses correntes do ano. A Emei, em todos os anos da pesquisa, executou valor inferior ao recebido, com exceção de 2009. Nos cinco anos, a escola recebeu o montante 
de $\mathrm{R} \$ 198.436,62$, realizando as despesas na ordem de $\mathrm{R} \$ 183.791,25$ e restando um saldo de $\mathrm{R} \$ 14.645,37$, valor reprogramado para 2011.

Os recursos não utilizados, no período de análise da pesquisa, são significativos. Considerando o total de recursos disponibilizado para o período, o saldo reprogramado é de $7,4 \%$, ou cerca de $40 \%$ dos recursos repassados para o ano de 2010. A diretora da Emei apresentou algumas dificuldades em realizar as despesas. Ao ser questionada se o PTRF atendia às especificidade da Emei, ela respondeu que algumas amarras postas pelos responsáveis, no âmbito regional pela prestação de contas, atrapalhavam a autonomia da escola e se não fosse isso os recursos poderiam atender melhor as necessidades da escola.

Novamente, esbarra-se em dificuldades do processo de utilização dos recursos que acabam trazendo uma demanda extra para a escola, que, em vez de ajudar a criar soluções próprias para seus problemas acaba criando mais um problema para a escola.

O Gráfico 10 mostra os valores das despesas em material de consumo, material permanente, serviços de terceiros, transporte, tarifas e taxas.

Gráfico 10 - Montante de recursos gastos do PTRF por tipo de despesa na Emei, por ano (em $\mathrm{R} \$)$

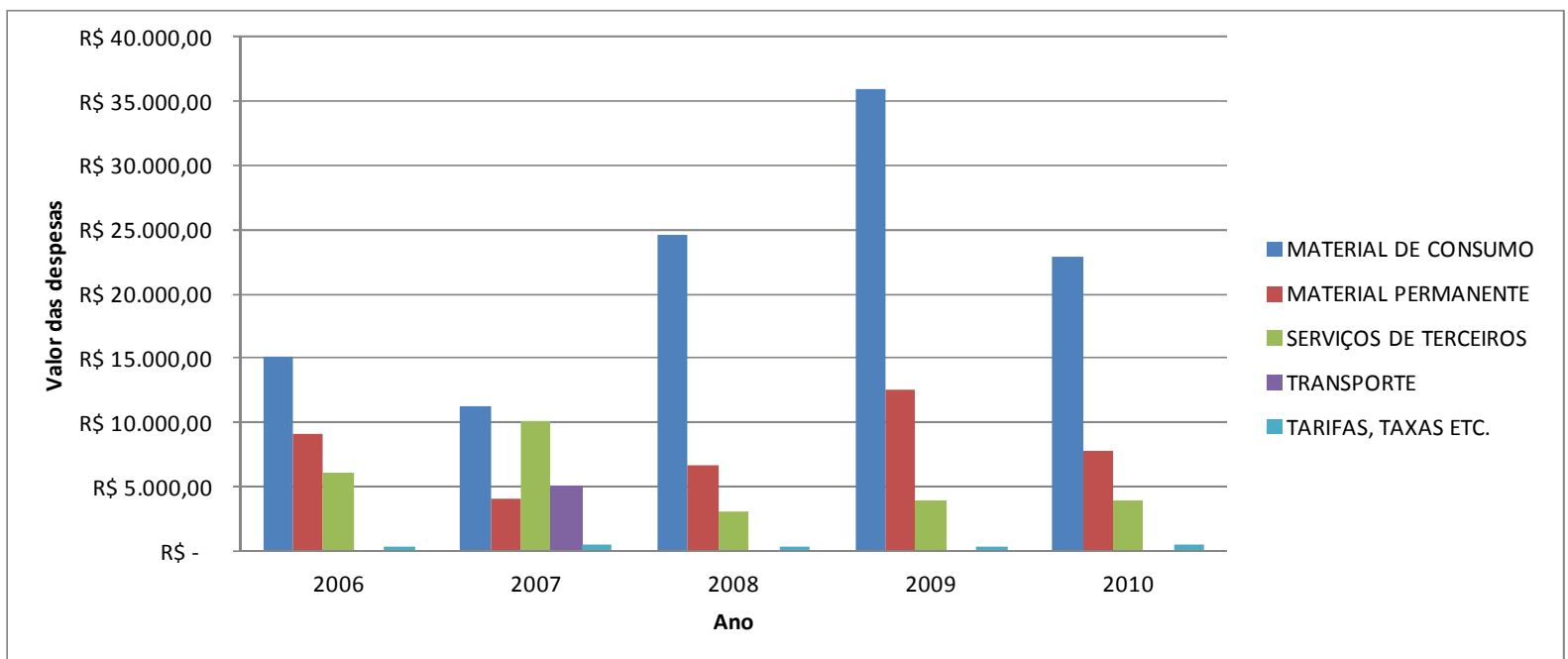

Fonte: Elaborado pelo autor, com base nos dados levantados na pesquisa de campo. Valores deflacionados para 12/2010, pelo INPC (IBGE).

No período de análise da pesquisa, a despesa com material de consumo foi a maior. A despesa com material permanente teve seu maior valor no ano de 2009, acima de R\$ 12 mil, e o menor, em 2007, inferior a $\mathrm{R} \$ 5$ mil. A despesa com serviços de terceiros nos dois primeiros anos tiveram os maiores valores, acima dos R 5 mil, sendo que em 2007 o valor chegou a R\$ 
10 mil. Nos anos seguintes, há uma redução de despesas nesse item, com valores inferiores aos R $\$ 5$ mil. Observa-se que as despesas em transporte foram realizadas somente no ano de 2007. A diretora da Emei justifica essa situação.

\begin{abstract}
Contratação de ônibus para levar os alunos para atividades externas. Teve uma vez que a gente pôde levar. Depois disso, eles começaram a criar empecilhos. Se você olhar lá no PTRF está previsto, mas eles colocam que não, porque existem atas de tomadas de preço e tem que ter solicitação. Só que você solicita ônibus na Diretoria de Ensino, você consegue dois no semestre, em uma escola que tem 600 alunos, você precisa de quantos? Você precisa de 12 ônibus, então não dá conta. E se você aluga, eles ainda vão questionar. E corre o risco de ter que devolver.
\end{abstract}

No Gráfico 11, pode-se observar o comportamento das despesas realizadas por tipo, em percentuais por ano.

Gráfico 11- Recursos gastos do PTRF por tipo de despesa da Emei, por ano (em \%)

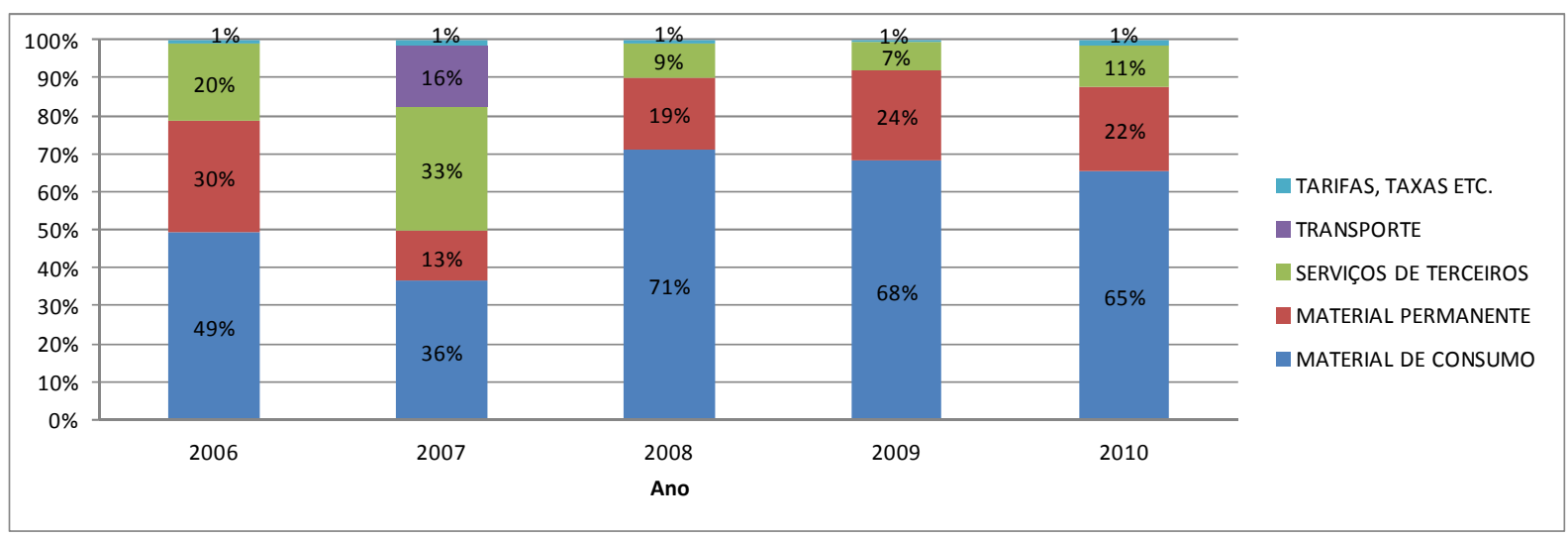

Fonte: Elaborado pelo autor, com base nos dados levantados na pesquisa de campo. Valores deflacionados para 12/2010, pelo INPC (IBGE).

O ano de 2007 apresenta uma variação significativa em relação aos outros, que se deve, principalmente, pelos gastos em transporte e à elevação dos gastos em serviços de terceiros; nesse ano, os dois tipos de despesas representam 49\% do total. A partir de 2008, os gastos apresentam uma tendência mais estável.

Uma das demandas colocadas por todos os entrevistados da Emei foi fechar os corredores com cortinas roll-on, caracterizado como material permanente e deduzido dos recursos para capital. Inclusive a mãe da Emei salienta que foi necessário que a escola se programasse para poder realizar esse gasto: "[...] quando a gente faz um levantamento de prioridades, de necessidades, você vê que não dá, aí fala que vai deixar pro ano que vem, 
esperava dois repasses pra fazer. Por exemplo, os toldos da escola foram colocados em quatro anos".

No caso da Emei, pelas entrevistas, evidencia-se uma necessidade de mais recursos para a aquisição de materiais permanentes, nesse sentido, a escola fez a opção, em 2010, por alterar para $40 \%$ os recursos para capital do $2^{\circ}$ e do $3^{\circ}$ repasse.

É muito interessante que a direção da escola aponte as necessidades da instituição, com base no projeto político pedagógico. Contudo, isso revela outra questão (já apontada também no caso do CEI): que escola é essa que a rede está disponibilizando para a população? A escola é aberta, recebe as crianças, mas não tem as condições para atendê-las, são necessárias inúmeras adequações do espaço físico e materiais para desenvolver o trabalho pedagógico. Retomando a fala da mãe, foram necessários quatro anos para garantir que as crianças não ficassem à mercê das intempéries do clima. Assim, surge outra indagação: essas adequações deveriam ser responsabilidade da escola? Ou seria responsabilidade da SME?

O Quadro 6 explicita as despesas realizadas no período de análise, classificando-as em pedagógicas e não pedagógicas. As despesas com o pedagógico foram: brinquedos pedagógicos, equipamentos multimídias, brinquedos para o parque, transporte de alunos, expediente pedagógico (material de papelaria de uso direto com os alunos), brinquedos com a temática da inclusão e manutenção de equipamento de uso direto com os alunos. E as despesas com o não pedagógico foram realizadas com: taxas e tarifas, manutenção e adequação do espaço físico, material de expediente para secretaria, talheres para sistema de self-service e serviço contábil. 
Quadro 6- Despesas em pedagógico e não pedagógico com recursos do PTRF da Emei, por ano (em R\$ e \%)

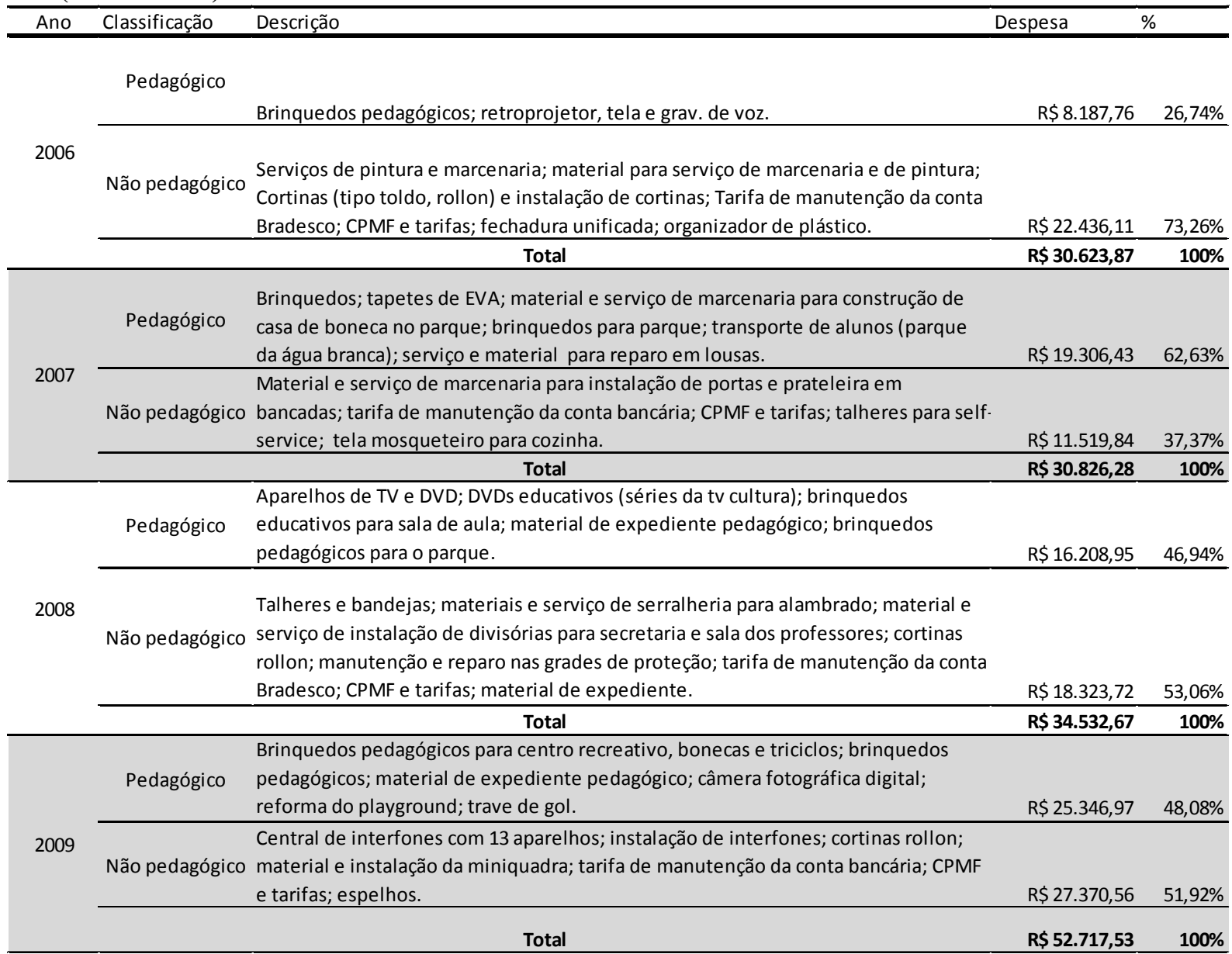

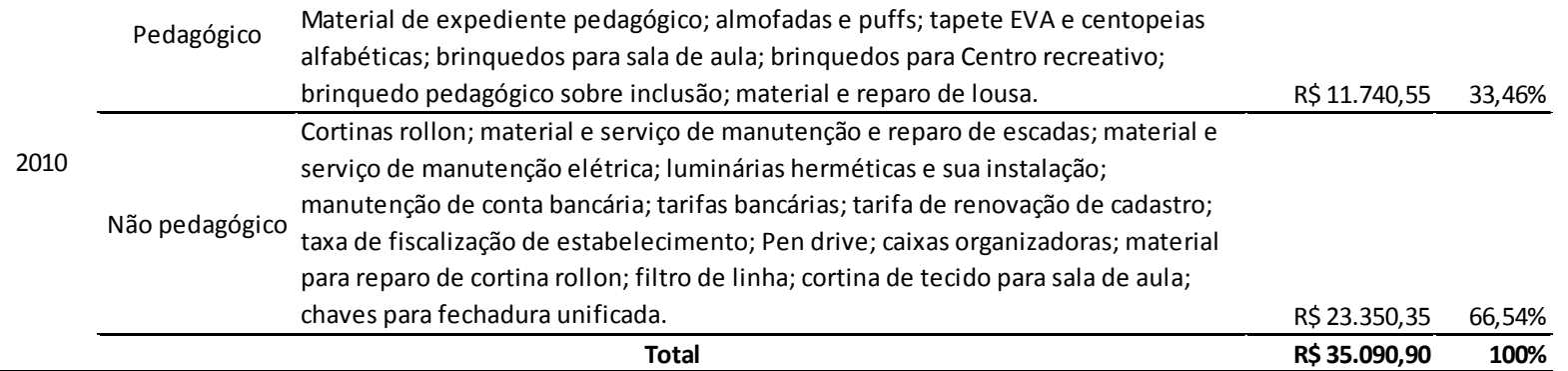

Fonte: Elaborada pelo autor, com base nos dados levantados na pesquisa de campo. Valores deflacionados para 12/2010, pelo INPC (IBGE).

As despesas com o pedagógico tiveram o menor montante em 2006, com cerca de $\mathrm{R} \$ 8$ mil, ano em que a Emei realizou o menor montante de despesas. Com o não pedagógico foi registrado o menor montante em 2007, R \$ 11 mil. Em 2009, a escola apresentou o maior valor em despesas desse tipo, aproximadamente R $\$ 25$ mil. No mesmo ano, atinge o maior montante de despesas no período, quando também coincide o maior valor em despesas com o não pedagógico, por volta de $\mathrm{R} \$ 27$ mil. 
Gráfico 12- Despesas pedagógicas e não pedagógicas com recursos do PTRF na Emei, por ano $(\mathrm{em} \%)$

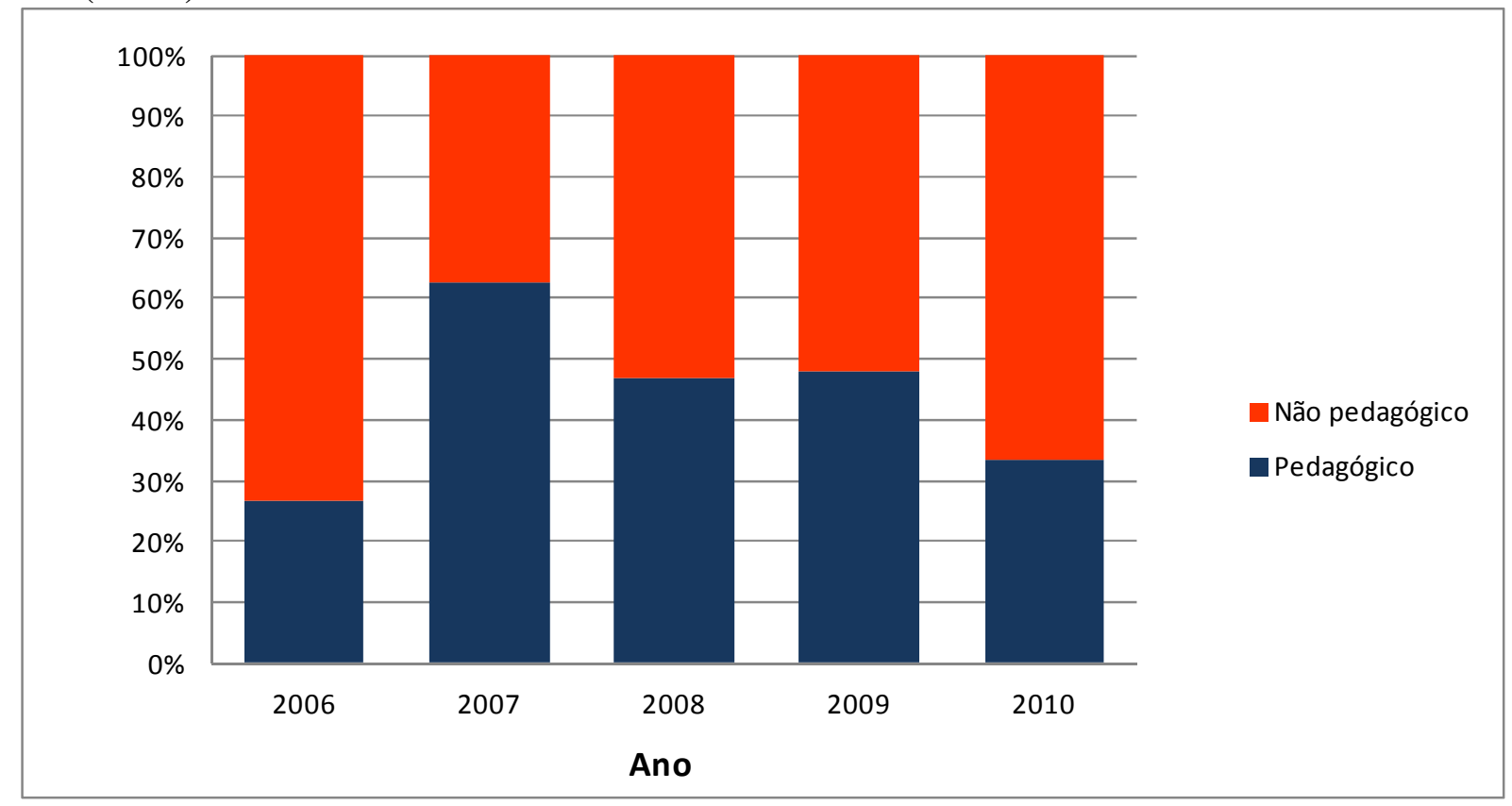

Fonte: Elaborado pelo autor, com base nos dados levantados na pesquisa de campo. Valores deflacionados para 12/2010, pelo INPC (IBGE).

O Gráfico 12, com a divisão das despesas em pedagógico e não pedagógico, em percentuais, demonstra que 2006 foi o ano em que mais se utilizou recursos em despesas não pedagógicas, chegando a quase $75 \%$. Em contrapartida, o ano que mais utilizou recursos com despesas pedagógicas foi o de 2007, com cerca de 60\%. Em 2008 e 2009, as despesas foram realizadas de forma equilibrada, próximas dos 50\% para cada categoria. Em 2010, volta a aumentar os gastos com não pedagógico, com aproximadamente $65 \%$.

Um dos fatores que acabam por determinar que a Emei utilize mais recursos em despesas não pedagógicas está ligado à necessidade de adequação dos espaços. Esses serviços, em geral, são bem onerosos. Observadas as despesas realizadas no período, nota-se que a escola instalou cortinas do tipo roll-on para proteger as crianças das intempéries, pois segundo o relato dos membros da comunidade escolar, do contrário, elas ficariam expostas à chuva e ao vento, ou "presas" nas salas de aula.

No ano de 2009, a miniquadra não está considerada como pedagógico, porque se trata de adequação/construção de espaço. Embora o uso da quadra seja pedagógico, há uma diferença em equipar um espaço para desenvolver as atividades e construir um espaço. Partese do pressuposto que a construção tinha como finalidade de ser uma escola. Portanto, cabe à SME garantir que o espaço tenha as características necessárias e não transferir essa responsabilidade para a escola, depois de iniciadas as atividades. Em situação análoga, é 
diferente a escola usar os recursos descentralizados para equipar uma sala de aula preexistente com aparelhos multimídias, do que ter que construir uma nova sala.

\subsubsection{Recursos financeiros e gastos do PTRF da Emef}

No período de análise da pesquisa, foram considerados para a Emef os seguintes números de matrículas: 1.200, para o ano de 2006; 1.091, para 2007; 959, para 2008; 1.216, para 2009 e 1.063, para 2010. Obedecendo-se aos critérios estipulados para cada ano e o número de matrículas computadas, a

Tabela 13 traz os recursos do PTRF recebidos, por categoria econômica e total por ano, no período em que a pesquisa aborda. No ano de 2006 conta como saldo de R\$ 648,11, que foi reprogramado do ano de 2005.

Tabela 13 - Recursos financeiros recebidos do PTRF pela Emef, por ano (em R\$ e \%)

\begin{tabular}{lrrrrrr}
\hline Ano & $\mathbf{2 0 0 6}$ & $\mathbf{2 0 0 7}$ & $\mathbf{2 0 0 8}$ & $\mathbf{2 0 0 9}$ & $\mathbf{2 0 1 0}$ & Total \\
\hline Custeio $(\mathrm{R} \$)$ & $48.729,76$ & $40.736,60$ & $37.016,68$ & $44.537,72$ & $35.394,70$ & $206.415,45$ \\
Capital $(\mathrm{R} \$)$ & $2.722,47$ & $10.184,15$ & $9.254,17$ & $11.134,43$ & $10.772,30$ & $44.067,52$ \\
Total & $51.452,24$ & $50.920,75$ & $46.270,85$ & $55.672,14$ & $46.167,00$ & $250.482,98$ \\
\% para custeio & 95 & 80 & 80 & 80 & 77 & 82 \\
\% para capital & 5 & 20 & 20 & 20 & 23 & 18 \\
\hline
\end{tabular}

Fonte: Elaborada pelo autor, com base nos dados levantados na pesquisa de campo. Valores deflacionados para 12/2010, pelo INPC (IBGE).

O total de receitas para custeio, no período, foi da ordem de $\mathrm{R} \$ 206$ mil e de $\mathrm{R} \$ 44$ mil para capital, perfazendo um total de $\mathrm{R} \$ 250$ mil. O ano com o menor montante de recursos foi 2010, com R\$35.394,70. Em 2009, a Emef recebeu o maior montante de recursos, o que ocorreu devido ao fato de que nesse ano apresentou o maior número de matrículas para efeito de cálculo e recebeu também os recursos adicionais por economia de energia e água. Em relação à divisão nas categorias econômicas, os anos de 2007, 2008 e 2009 apresentaram os percentuais definidos na normatização legal do período. Os que apresentaram diferenças na divisão têm duas razões: em 2006, os recursos destinados para despesas em capital somente foram regulamentados no último repasse; e, em 2010, a legislação permitia que as escolas optassem por alterar os percentuais para cada categoria econômica. 
Tabela 14 - Despesas realizadas com recursos do PTRF pela Emef, por ano (em R\$ e \%)

\begin{tabular}{lrrrrrr}
\hline Ano & $\mathbf{2 0 0 6}$ & $\mathbf{2 0 0 7}$ & $\mathbf{2 0 0 8}$ & $\mathbf{2 0 0 9}$ & $\mathbf{2 0 1 0}$ & Total \\
\hline Despesas em Custeio $(\mathrm{R} \$)$ & $25.965,47$ & $32.991,86$ & $28.877,01$ & $53.264,44$ & $38.435,73$ & $179.534,51$ \\
Despesas em Capital $(\mathrm{R} \$)$ & $9.620,63$ & $1.855,24$ & $10.338,48$ & $10.438,77$ & $10.678,70$ & $42.931,82$ \\
Total $(\mathrm{R} \$)$ & $35.586,10$ & $34.847,11$ & $39.215,48$ & $63.703,21$ & $49.114,43$ & $222.466,33$ \\
$\%$ de custeio & 73 & 95 & 74 & 84 & 78 & 81 \\
\% de capital & 27 & 5 & 26 & 16 & 22 & 19 \\
\hline
\end{tabular}

Fonte: Elaborada pelo autor, com base nos dados levantados na pesquisa de campo. Valores deflacionados para 12/2010, pelo INPC (IBGE).

Pela Tabela 14, que traz a relação das despesas do PTRF em custeio e em capital e total, por ano, pode-se considerar que a Emef entendeu que os recursos poderiam ser gastos em despesas de capital no ano de 2006, sendo superior ao montante de R $2.722,47$, destinados à despesa de capital do $4^{\underline{0}}$ repasse. Em 2007, a execução das despesas foi, predominantemente, realizada na categoria de custeio, com somente $5 \%$ gastos em despesas de capital. Entretanto, no ano de 2008, o percentual de recursos com capital chegou a $26 \%$ das despesas, inclusive superior ao repasse para o ano, tendo, assim, que utilizar os recursos reprogramados do ano anterior. Em 2009, as despesas de capital foram inferiores aos 20\%; contudo, o valor executado foi muito próximo do repassado para o ano. Esse movimento evidencia uma necessidade expressiva de investimento de bens permanentes; podendo-se notar inclusive pela opção da escola em aumentar os percentuais do $3^{-0}$ repasse dos recursos financeiros para a despesa de capital de $20 \%$ para $30 \%$. Nesse ano, a escola despendeu R $\$$ $10.678,70$ dos $\mathrm{R} \$ 10.772,30$ transferidos. O Gráfico 13, que representa os montantes recebidos do programa, o total das despesas e os saldos reprogramados, nos anos de análise da pesquisa, mostra que, em 2006, a escola contou também com R\$ 809,39 de saldo reprogramado do ano anterior. Nos três primeiros anos analisados, a escola realizou um total de despesas inferior aos montantes repassados pelo PTRF. Já nos anos seguintes, os valores foram superiores. Nesse período, a escola recebeu do programa o total de R $\$ 251.292,36$ e realizou a despesa total de $\mathrm{R} \$ 222.466,33$, restando um saldo de $\mathrm{R} \$ 28.826,03$ a ser reprogramado para o ano de 2011. Os recursos perfazem a ordem de $11 \%$ dos recursos disponibilizados, ou cerca de $60 \%$ dos repassados no ano de 2010, o que mostra que não são desprezíveis os recursos que são reprogramados. 
Gráfico 13 - Receita, gasto e saldo reprogramado dos recursos do PTRF da Emef, por ano (em R\$)

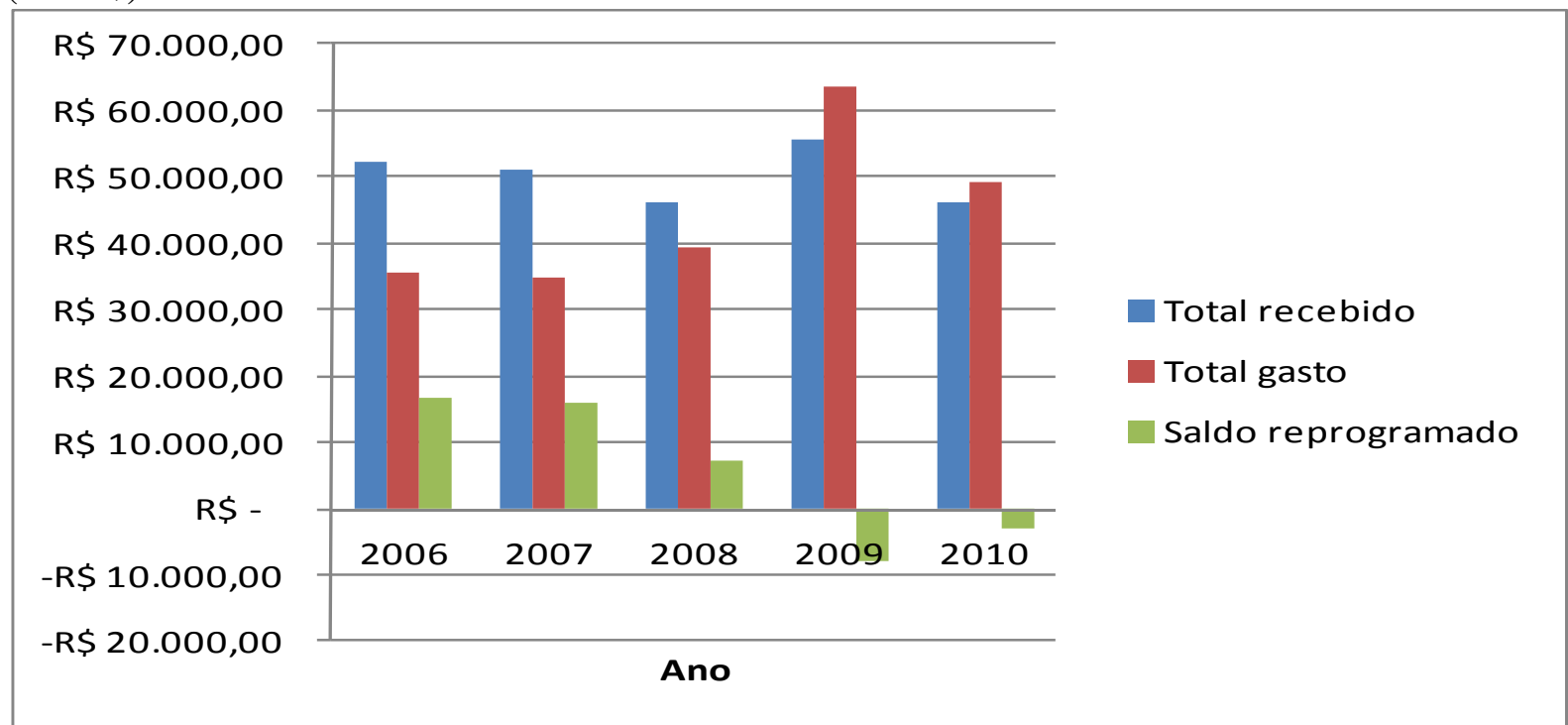

Fonte: Elaborado pelo autor, com base nos dados levantados na pesquisa de campo. Valores deflacionados para 12/2010, pelo INPC (IBGE).

O Gráfico 14 ilustra as despesas em quatro itens: material de consumo, material permanente, serviços de terceiros e tarifas e taxas. No período analisado, o material de consumo foi o item que mais despendeu recursos. Em 2009, tem-se um aumento de cerca de $240 \%$ nas despesas com serviços de terceiros, passando de $\mathrm{R} \$ 6.517,69$, em 2008, para $\mathrm{R} \$$ 22.471,41, em 2009.

Gráfico 14 - Montante de recursos gastos do PTRF por tipo de despesa na Emef, por ano (em $\mathrm{R} \$)$

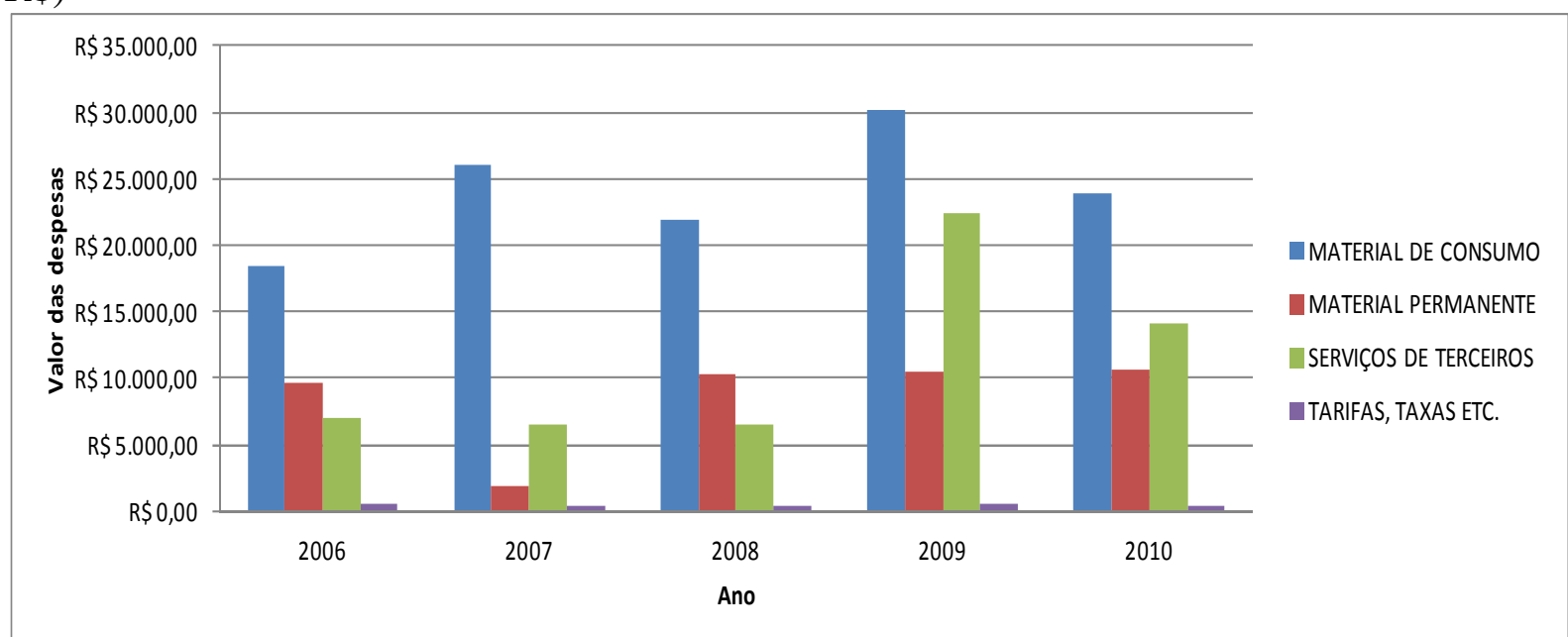

Fonte: Elaborado pelo autor, com base nos dados levantados na pesquisa de campo. Valores deflacionados para 12/2010, pelo INPC (IBGE). 
No Gráfico 15, pode-se observar quanto cada item representa no total das despesas em cada ano. Com exceção de 2007, o gasto em materiais de consumo tem se mantido em torno dos $50 \%$. Já as despesas com serviços de terceiros têm se elevado, visto que nos três primeiros anos estava abaixo dos 20\%, em 2009, chega aos 35\% e, em 2010, fica em 29\% do total.

Quanto à aquisição de material permanente, é interessante notar que, mesmo no ano de 2006, com uma insegurança jurídica sobre realizar despesas de capital, na Emef, os gastos foram da ordem de $27 \%$. Com exceção de 2007, com gastos de apenas $5 \%$, em todos os outros anos, as aquisições foram bem próximas do total de recursos disponibilizados para capital no ano. Inclusive, em 2010, a escola fez a opção no $3^{\circ}$ repasse por alterar o montante de recursos para capital de $20 \%$ para $30 \%$.

Gráfico 15 - Recursos gastos do PTRF por tipo de despesa da Emef, por ano (em \%)

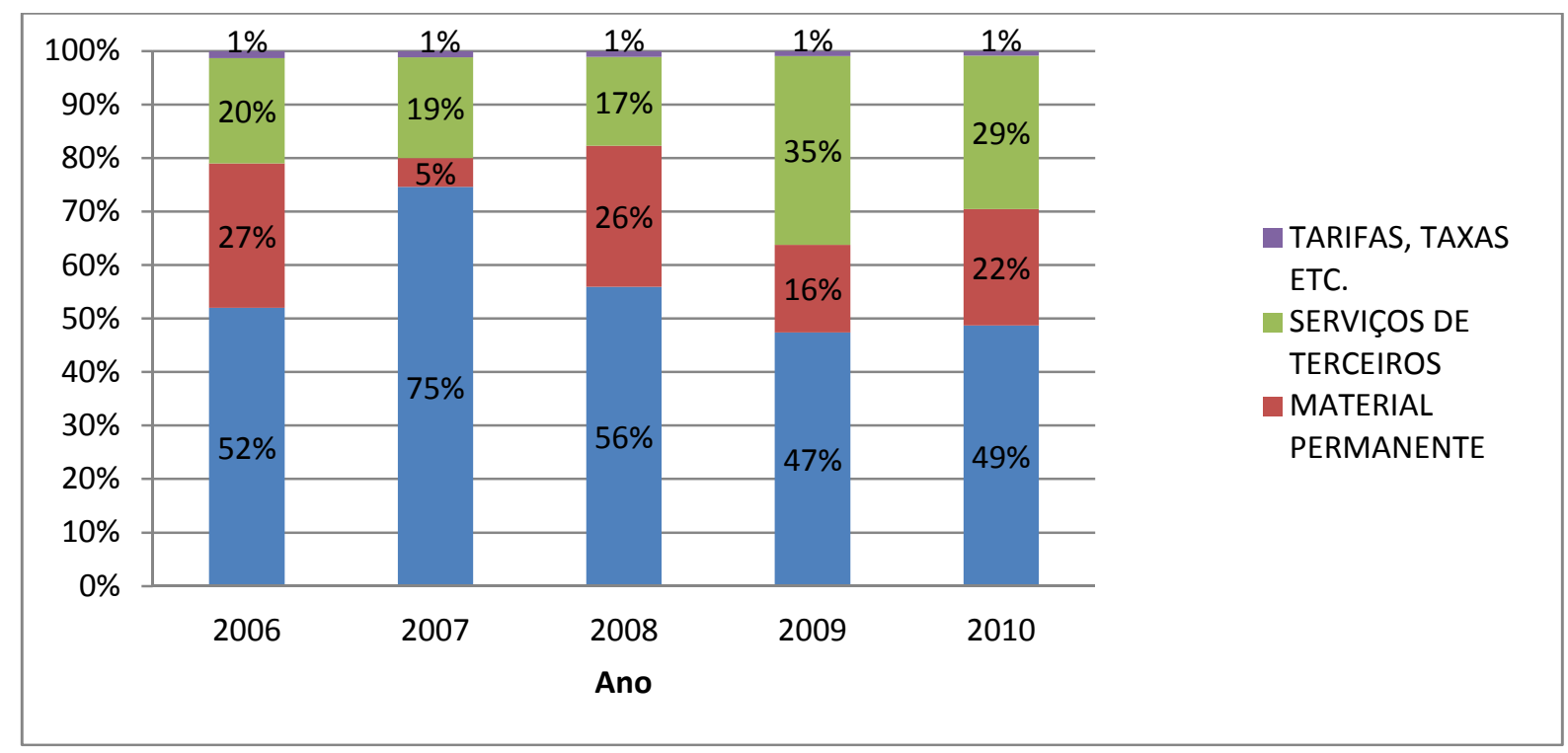

Fonte: Elaborado pelo autor, com base nos dados levantados na pesquisa de campo. Valores deflacionados para 12/2010, pelo INPC (IBGE).

Ao perguntar para a diretora da Emef sobre as principais demandas, ela respondeu que seriam: "Papelaria, equipamento eletroeletrônico, muitas vezes. Adequação de espaços. A gente está fazendo uma brinquedoteca, por exemplo. Tem um pátio, ainda não está totalmente pronto, ainda faltam algumas coisas." A professora entrevistada da Emef destaca que há muita demanda de materiais, chamados por ela de "diferenciados", por exemplo, bússola para as aulas de geografia. A diretora destaca outro tipo de gastos:

E em um primeiro momento, a gente cuidou de trazer coisas bacanas para a escola. Vou dar um exemplo: - Compra duplicadora digital, compra impressora não sei o 
$q u \hat{e}$. Agora, nós estamos em um momento que foi agregando custo fixo para manter. Então, além das coisas bacanas que muita gente colocou dentro da escola.

À medida que a escola passa a adquirir bens permanentes incorpora às suas necessidades a manutenção desses bens patrimoniais, além das de conservação do prédio e imobiliário que recebem da SME. Assim, pode-se observar que essa questão corrobora para o aumento das despesas em serviços de terceiros.

O Quadro 7 sistematiza os gastos da Emef em pedagógicos e não pedagógicos, no período analisado. Foram consideradas despesas com pedagógico: expediente pedagógico, material esportivo, livros, material de informática, equipamentos de multimídia, brinquedos, material para aulas de artes, jogos pedagógicos, serviço de gráfica, material pedagógico. E como não pedagógicos: expediente de secretaria, manutenção predial, adequação de espaços, tarifas bancárias, serviço contábil, tarifas cartoriais e taxas. 
Quadro 7- Despesas em pedagógico e não pedagógico com recursos do PTRF da Emef, por ano (em R\$ e \%)

\begin{tabular}{|c|c|c|c|c|}
\hline Ano & Classificação & Descrição & Despesa & $\%$ \\
\hline \multirow[t]{3}{*}{2006} & Pedagógico & $\begin{array}{l}\text { Material esportivo; expediente pedagógicos; serviço de gráfica para impressão de ficha } \\
\text { de avaliação; material para aulas de educação artística; brinquedos; fantasias; } \\
\text { materiais para artesanato; jogos educativos; lenço para instrumento;camisetas e } \\
\text { estamparia (banda da escola); fones de ouvido e mouse; dicionário inglês c/ CD-ROM e } \\
\text { livro didático; Toner; adaptador de vhs; revelação de foto; cartucho de tinta- impressora; } \\
\text { DVD; Caixa de som amplificada e microfone; atlas geográfico; quadros de cortiça; } \\
\text { aluguel de futebol de sabão, pula-pula e alpinismo inflável; servço e material para } \\
\text { reparo de quadro de aviso e suporte de TV e Vídeo e instalação. }\end{array}$ & $\mathrm{R} \$ 19.766,26$ & $55,54 \%$ \\
\hline & Não pedagógico & $\begin{array}{l}\text { Cartucho para fax; serviço de marcenaria; ar-condicionado e evaporador; material e } \\
\text { instalação de ar-condicionado; manutenção da conta bancária; tarifas bancárias e } \\
\text { CPMF; registro de ata da APM; porta tudo e toalha; caixa plástica e estante de aço; } \\
\text { pratos e cesto multi-uso; caixa organizador; cortina e lona; escada e carrinho; } \\
\text { canteadeira e furador; estante rack multi-uso; material de expediente de secretaria. }\end{array}$ & $\mathrm{R} \$ 15.819,84$ & $44,46 \%$ \\
\hline & & Total & $\mathrm{R} \$ \mathbf{3 5 . 5 8 6 , 1 0}$ & $100 \%$ \\
\hline \multirow{3}{*}{2007} & Pedagógico & $\begin{array}{l}\text { Material esportivo; utensílios de cozinha descartáveis para aula de artes; material para } \\
\text { a orquestra de cordas; expediente pedagógico; flautas plasticas. }\end{array}$ & $\mathrm{R} \$ 9.211,53$ & $26,43 \%$ \\
\hline & Não pedagógico & $\begin{array}{l}\text { Material de expediente secretaria; material para manutenção dos banheiros; material } \\
\text { para manutenção do piso; material para pintura; lata de lixo para coleta seletiva; } \\
\text { carrinho para transporte de materiais; serviços contábeis; senvço de remoção de } \\
\text { resíduos e pintura; tarifa de manutenção de conta bancária e CPMF. }\end{array}$ & $\mathrm{R} \$ 25.635,57$ & $73,57 \%$ \\
\hline & & Total & $\mathrm{R} \$ 34.847,11$ & $100 \%$ \\
\hline \multirow{3}{*}{2008} & Pedagógico & $\begin{array}{l}\text { Brinquedos; expediente pedagógico; manutenção de brinquedos infláveis; fitas VHS e } \\
\text { pilhas para filmadora; carregador de bateria de filmadora; filmadora. }\end{array}$ & $\mathrm{R} \$ 6.518,93$ & $16,62 \%$ \\
\hline & Não pedagógico & $\begin{array}{l}\text { Material de expediente para secretaria; lixeiras; materiais para pintura; material para } \\
\text { conserto de persianas/cortinas; material para manutenção de banheiro; cortina rollon e } \\
\text { instalação; cortinas; material para aquário; tarifa de manutenção de conta bancária e } \\
\text { CPMF; registro de ATA; taxa de fiscalização de estabelecimento. }\end{array}$ & $\mathrm{R} \$ 32.696,55$ & $83,38 \%$ \\
\hline & & Total & $\mathrm{R} \$ 39.215,48$ & $100 \%$ \\
\hline \multirow{3}{*}{2009} & Pedagógico & $\begin{array}{l}\text { Expediente pedagógico; jogos de pedagógicos; tampos de carteiras; cabos para vídeo } \\
\text { e áudio; suporte para som; micro system; projetor e suporte; caixas de som; } \\
\text { amplificador e caixas de som; serviço de gráfica para impressão de ficha de avaliação } \\
\text { de aluno para prontuário; instalação de varal nas salas de aula (para exposição dos } \\
\text { trabalhos); conserto de TV e gravador de CD. }\end{array}$ & $\mathrm{R} \$ 22.049,37$ & $34,61 \%$ \\
\hline & Não pedagógico & $\begin{array}{l}\text { Material de expediente de secretaria; cestos para acondicionamento; assento para } \\
\text { banheiro e capacho; manutenção de banheiro para deficiente; lixeiras; dispensador de } \\
\text { copos; material para preparo e pintura; telefones; bebedouro; ventilador de mesa; } \\
\text { escadas; fragmentadora de papel; suporte de monitor; lavagem de cortina; reparo em } \\
\text { impressora, scanner e fax; serviços contábeis; instalação de toldos; serviço de } \\
\text { serralheria para confecção de portão; tarifa de manutenção de conta bancária; Taxa de } \\
\text { Fiscalização de Estabelecimento. }\end{array}$ & $\mathrm{R} \$ 41.653,84$ & $65,39 \%$ \\
\hline & & Total & $R \$ 63.703,21$ & $100 \%$ \\
\hline \multirow{3}{*}{2010} & Pedagógico & $\begin{array}{l}\text { Material esportivo; expediente pedagógico; jogos e brinquedos; avental de história; } \\
\text { mapas. }\end{array}$ & $\mathrm{R} \$ 24.472,31$ & $49,83 \%$ \\
\hline & Não pedagógico & $\begin{array}{l}\text { Material de expediente da secretaria; manutenção de banheiros; luminária de } \\
\text { emergência; lâmpadas fluorescentes; testeira (borracha de escada); material para } \\
\text { pintura; suporte e placa de sinalização de extintores; disco rígido externo; mesa } \\
\text { professor; cortinas; bebedouro; senvços contábeis; senvço de serralheria conserto de } \\
\text { portas e janelas; chaveiro unificação de segredo de fechadura e instalação; lavagem de } \\
\text { cortinas; colocação de ganchos e placas de extintores; tarifa de manutenção de conta } \\
\text { bancária; Taxa de Fiscalização de Estabelecimento. }\end{array}$ & $\mathrm{R} \$ 24.642,12$ & $50,17 \%$ \\
\hline & & Total & $\mathrm{R} \$ \mathbf{4 9 . 1 1 4 , 4 3}$ & $100 \%$ \\
\hline
\end{tabular}

Fonte: Elaborada pelo autor por base nos dados levantados na pesquisa de campo. Valores deflacionados para 12/2010, pelo INPC (IBGE).

Em 2006, os gastos com pedagógico foram de $\mathrm{R} \$ 19.766,26$, correspondendo a $55,54 \%$ dos recursos utilizados, que, no ano seguinte, caem para apenas $\mathrm{R} \$ 9.211,53$, o que representa um decréscimo de 50\%. Em 2008, a queda na aplicação do recurso continua, perfazendo apenas $\mathrm{R} \$ 6.518,93$. No ano de 2009, a aplicação dos recursos em pedagógico apresenta uma elevação significativa, totalizando $\mathrm{R} \$ 22.049,37$, contudo para os gastos desse ano, os recursos correspondiam a apenas 34,61\% dos utilizados. Em 2010, os recursos foram 
de $\mathrm{R} \$ 24.472,31$, atingindo o maior montante do período analisado e representando 49,83\% dos recursos aplicados nesse ano.

Os recursos classificados como não pedagógicos, em 2006, foram de $\mathrm{R} \$ 15.819,84$. Nos anos seguintes, houve um crescimento nesse tipo de despesa: em 2007, foram R\$ 25.635,57; em 2008, cresceu para $\mathrm{R} \$ 32.696,55$, atingindo o maior montante em 2009, com $\mathrm{R} \$ 41.653,84$, um crescimento de $163 \%$ em relação ao praticado no ano de 2006. Em 2010, houve uma redução, em termos de montante, nos gastos, perfazendo $\mathrm{R} \$ 24.642,12$, contudo ainda representando $50,17 \%$ do gasto anual.

Gráfico 16 - Despesas pedagógicas e não pedagógicas com recursos do PTRF na Emef, por ano (em \%)

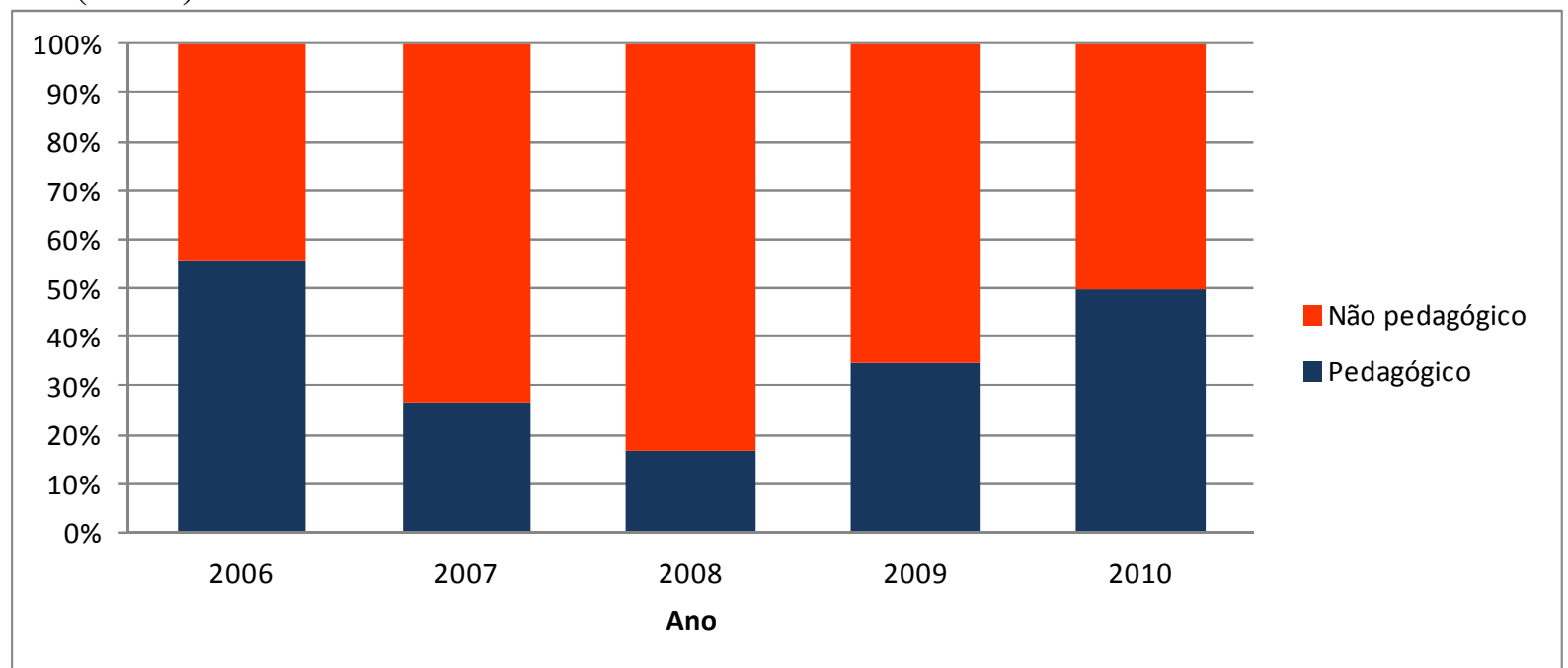

Fonte: Elaborado pelo autor, com base nos dados levantados na pesquisa de campo. Valores deflacionados para 12/2010, pelo INPC (IBGE).

O Gráfico 16, com os percentuais dos gastos classificados em pedagógicos e não pedagógicos, por ano da análise, ilustra que 2006 foi o único ano que a Emef realizou um percentual acima dos 50\% em despesas classificadas como pedagógicas. Em 2007, os gastos em pedagógico foram inferiores aos 30\%. Em 2008, a disparidade acentua-se, sendo apenas $16,62 \%$ realizados em pedagógicos contra 83,38\% com não pedagógicos. Em 2009, ano no qual foi realizado o maior montante ( $\mathrm{R} \$ 63.703,21)$, os recursos ficam em 65,39\% em despesas não pedagógicas e apenas 34,61\% em despesas pedagógicas. No ano de 2010, há um equilíbrio, representando praticamente $50 \%$ para cada tipo de despesa. 
4.2.4 Algumas comparações sobre os recursos do PTRF e seus usos no CEI, na Emei e na Emef

Neste item do trabalho, pretende-se analisar conjuntamente os recursos recebidos pelas três escolas e as despesas realizadas, proporcionando uma breve comparação no emprego dos recursos do PTRF. Primeiro, observam-se as receitas oriundas do programa, posteriormente os valores executados em cada escola e, por fim, o emprego dos recursos classificados em pedagógicos e não pedagógicos.

Por meio da Tabela 15, observa-se que o CEI, em todos os anos da análise, foi a escola que recebeu menor montante de recursos por ano e no total do período, com o valor máximo de $\mathrm{R} \$ 18.884,00$, em 2009. Em contrapartida, a Emef foi a que mais recebeu recursos do programa, tanto por ano como no total do período analisado, sendo o menor valor $\mathrm{R} \$$ 46.167,00, em 2010, e o maior, em 2009, com R 55.672,00. A Emei recebeu montantes intermediários entre as duas escolas. Percebe-se também que o menor valor recebido pela Emei, R\$35.376,00, em 2010, é superior ao maior montante recebido pelo CEI, enquanto que o maior, $\mathrm{R} \$ 42.883,00$, em 2009, é inferior ao menor valor recebido pela Emef.

Tabela 15 - Receitas totais e por aluno do PTRF, no CEI, na Emei e na Emef, por ano (em $\mathrm{R} \$)$

\begin{tabular}{c|rr|rr|rr}
\hline & \multicolumn{2}{|c|}{ CEI } & \multicolumn{2}{c|}{ EMEI } & \multicolumn{2}{c}{ EMEF } \\
Ano & \multicolumn{1}{|c|}{ Receita } & Por aluno & Receita & Por aluno & Receita & Por aluno \\
\hline 2006 & 4.116 & 14 & 41.371 & 60 & 51.452 & 43 \\
2007 & 15.717 & 53 & 40.815 & 58 & 50.921 & 47 \\
2008 & 14.677 & 49 & 37.946 & 55 & 46.271 & 48 \\
2009 & 18.884 & 64 & 42.883 & 62 & 55.672 & 46 \\
2010 & 16.080 & 57 & 35.376 & 55 & 46.167 & 43 \\
Total & $\mathbf{6 9 . 4 7 4}$ & $\mathbf{2 3 8}$ & $\mathbf{1 9 8 . 3 9 0}$ & $\mathbf{2 8 9}$ & $\mathbf{2 5 0 . 4 8 3}$ & $\mathbf{2 2 7}$ \\
\hline
\end{tabular}

Fonte: Tabela elaborada pelo autor, com base nos dados levantados na pesquisa de campo. Valores deflacionados para 12/2010, pelo INPC (IBGE).

Ao dividirmos os montantes recebidos pelo número de alunos, a dinâmica dos valores se altera. Na somatória dos valores recebidos, por aluno, a Emei foi a que recebeu maior valor ( $\mathrm{R}$ \$ 289), seguido pelo CEI ( $\mathrm{R} \$ 238$ ) e a Emef, com menor valor ( $\mathrm{R} \$ 227)$. O menor valor praticado por aluno por ano foi $\mathrm{R} \$ 14$, em 2006, pelo CEI. Cabe lembrar que, nesse ano, o CEI teve problemas para receber na íntegra os valores. Com exceção do ano de 2006, a Emef 
recebeu os menores valores por aluno. Em 2006, 2007 e 2008, a Emei obteve os maiores valores por aluno, enquanto que nos anos de 2009 e 2010, esse registro foi do CEI.

A análise da Tabela 15 permite constatar que, embora a educação infantil receba montantes menores de recursos, os valores por alunos por ano são superiores aos recebidos pela Emef. Cabe lembrar que o fato de os valores por alunos da educações infantil serem maiores que os do ensino fundamental não significa uma priorização, pois a fórmula adotada para o cálculo dos valores a serem destinados não considera o tempo de permanência dos alunos nas escolas.

A seguir, a Tabela 16 sistematiza as despesas realizadas pelas escolas, no período analisado, em valores por ano e por aluno/ano.

Tabela 16 - Despesas totais e por aluno do PTRF, no CEI, na Emei e na Emef, por ano (em $\mathrm{R} \$)$

\begin{tabular}{l|rr|rr|rr}
\hline & \multicolumn{2}{|c|}{ CEI } & \multicolumn{2}{c|}{ EMEI } & \multicolumn{2}{c}{ EMEF } \\
Ano & Despesa & Por aluno & Despesa & Por aluno & Despesa & Por aluno \\
\hline 2006 & 4.058 & 14 & 30.624 & 44 & 35.586 & 30 \\
2007 & 6.328 & 21 & 30.826 & 44 & 34.847 & 32 \\
2008 & 20.085 & 68 & 34.533 & 50 & 39.215 & 41 \\
2009 & 18.633 & 63 & 52.718 & 76 & 63.703 & 52 \\
2010 & 12.440 & 44 & 35.091 & 54 & 49.114 & 46 \\
Total & $\mathbf{6 1 . 5 4 4}$ & $\mathbf{2 1 0}$ & $\mathbf{1 8 3 . 7 9 1}$ & $\mathbf{2 6 8}$ & $\mathbf{2 2 2 . 4 6 6}$ & $\mathbf{2 0 1}$ \\
\hline
\end{tabular}

Fonte: Elaborada pelo autor, com base nos dados levantados na pesquisa de campo. Valores deflacionados para 12/2010, pelo INPC (IBGE).

O CEI, em todos os anos, foi a escola que realizou menor montante de despesas por ano e no total do período, com o valor máximo de R \$18.633,00, em 2009. Ano a ano a Emef foi a que mais utilizou seus recursos, seguida da Emei, que utilizou, em 2009, R\$ 52.718,00. A Emei realizou o maior valor de recursos, por aluno/ano ( $\mathrm{R} \$ 76,00)$, com exceção de 2008, único ano em que o CEI realizou o maior valor aluno/ano, com R \$ 68.

Agora, cabe discutir se esses recursos são suficientes ou não. Nas entrevistas realizadas nas três escolas, foi unânime a afirmação de que os recursos são insuficientes, ainda que sejam superiores aos de outras redes, como lembra a professora do CEI:

É claro que se tivesse mais seria melhor. Mas se eu comparar com alguns outros, como do estado, por exemplo, eu acho que a prefeitura tem mais recursos. Claro que 
falta, tanto é que tem que decidir por prioridades. Se tivesse mais, seria melhor. Lógico.

Entretanto, os depoimentos, de certa forma, contrastam com os dados levantados nas prestações de contas. Observado que as três escolas não executaram todos os recursos disponíveis, as entrevistas apontam outro elemento para a compreensão da não realização total dos gastos. Revelam que há certa dificuldade em realizar determinados gastos, por conta de impedimentos legais e burocráticos para a realização de despesas do orçamento público. Essa questão ilustra um dos obstáculos apresentados por Bobbio (2009), a oposição entre a tecnocracia e a democracia, que dificultam o processo democrático.

[...] o PTRF poderia ser melhor utilizado, do ponto de vista da gestão pedagógica, se não houvesse algumas amarras. Se a gente olhar lá na legislação geral, essas amarras não aparecem. Mas se a gente olhar quem faz a análise da prestação de contas aqui, no nível regional, a gente percebe. Inclusive eu já levei essa conversa para o diretor regional e infelizmente a gente não teve sucesso.

Mas o pessoal daqui é um tanto tacanho, vamos dizer assim, no entendimento sobre o uso do PTRF. Então acabam colocando algumas dificuldades, alguns senões no processo de prestação de contas. A gente acaba deixando de fazer justamente para não ter outras dores de cabeça. (DIRETORA DA EMEI)

A diretora da Emef descreve que o processo de realização das despesas e prestação de contas é tão complexo que gera inseguranças e dificuldades para executar os recursos.

\begin{abstract}
Não é possível, a gente ainda continua com medo, achando que tudo o que a gente vai comprar, a gente precisa consultar o papa, para saber se pode comprar. [...] Por exemplo, ontem. Uma nota de marcenaria, que eu bati o olho na nota e falei: "Essa nota vai dar problema, pelo o que o cara escreveu na nota". A minha assistente ficou apavorada: - E agora? - Corre lá. O setor de PTRF falou uma coisa. Eu tinha dito a ela: - Dependendo o que te falarem, você vai procurar o contador [da DRE]. [...] São três setores que ela foi e cada um falou uma coisa. Ela chegou aqui chorando: O que eu faço agora?
\end{abstract}

Gouveia (2010) em seu trabalho intitulado "Esquerda e Direita na Política

Educacional Municipal" dedica parte a analisa dos programas de descentralização de recursos financeiros nos municípios de Curitiba e Londrina. As gestoras desses municípios apresentaram considerações similares às encontradas nesta pesquisa.

A maioria dos respondentes nas duas cidades deu ênfase à positividade do programa na construção da autonomia da escola, principalmente destacando a agilidade na resolução dos problemas de manutenção, possibilidade de aquisição de material de qualidade e de acordo com as preferências de cada escola. Entretanto, houve também muitas respostas destacando que gestão financeira é apenas um aspecto da autonomia e muitas observações acerca dos problemas quanto a certa rigidez das 
regras de uso dos recursos que poderiam estar impedindo a real autonomia da escola. (GOUVEIA, 2010, p. 281)

A autora destaca que "há de se ponderar que elas estão usando recursos públicos que precisam ser aplicados a partir de critérios que assegurem transparência, economia e a lisura do processo" (GOUVEIA, 2010, p. 282). Embora o rigor na utilização dos recursos públicos seja imprescindível, não deve ser confundido com estabelecer amarras, verdadeiras camisas de força para sua realização. Deve-se cuidar para que os mecanismos/instrumentos internos da burocracia do Estado não sejam empecilhos na realização do trabalho nas escolas e, sim, devem estar a serviço das escolas, com o intuito de garantir o bom uso dos recursos públicos e facilitar a realização dos trabalhos, colaborando para construção de uma educação pública de qualidade.

Segue uma breve comparação da utilização dos recursos, pela classificação em pedagógico e não pedagógico. Trata-se de uma questão de interesse e já foi apresentada neste trabalho, em razão dos objetivos estabelecidos em lei para o programa e pela aprovação da Portaria 1845/2006 e sua revogação, na sequência.

A Tabela 17 reúne os montantes e valor por aluno/ano aplicados em pedagógico. Percebe-se que a Emei e a Emef aplicaram, na somatória do período, em despesas com pedagógico um valor muito próximo, sendo $\mathrm{R} \$ 80.791,00$ e $\mathrm{R} \$ 82.018,00$, respectivamente. O CEI aplicou no total apenas $\mathrm{R} \$ 36.929,00$, por volta de $45 \%$ em relação aos praticados pelas outras escolas. A menor aplicação dos recursos é registrada em 2006, pelo CEI, com R\$ 3.996,00, e a maior, em 2009, pela Emei, com um montante de R \$25.347,00. É interessante observar que o CEI, mesmo recebendo um valor menor de recursos por ano, em 2008, utilizou um montante para despesas com pedagógico $75 \%$ superior ao da Emef. 
Tabela 17 - Despesas totais e por aluno do PTRF, em pedagógico, no CEI, na Emei e na Emef, por ano (em R\$)

\begin{tabular}{c|rr|rr|rr}
\hline & \multicolumn{2}{|c|}{ CEI } & \multicolumn{2}{c|}{ EMEI } & \multicolumn{2}{c}{ EMEF } \\
Ano & Despesa & Por aluno & Despesa & Por aluno & Despesa & Por aluno \\
\hline 2006 & 3.996 & 14 & 8.188 & 12 & 19.766 & 16 \\
2007 & 4.353 & 15 & 19.306 & 27 & 9.212 & 8 \\
2008 & 11.478 & 39 & 16.209 & 24 & 6.519 & 7 \\
2009 & 8.146 & 28 & 25.347 & 36 & 22.049 & 18 \\
2010 & 8.955 & 32 & 11.741 & 18 & 24.472 & 23 \\
Total & $\mathbf{3 6 . 9 2 9}$ & $\mathbf{1 2 6}$ & $\mathbf{8 0 . 7 9 1}$ & $\mathbf{1 1 7}$ & $\mathbf{8 2 . 0 1 8}$ & $\mathbf{7 3}$ \\
\hline
\end{tabular}

Fonte: Elaborada pelo autor, com base nos dados levantados na pesquisa de campo. Valores deflacionados para 12/2010, pelo INPC (IBGE).

Nos valores gastos por aluno/ano do PTRF, observa-se que a escola que mais utilizou recursos com pedagógico na somatória do período foi o CEI, com o valor de R \$126, seguido pela Emei, com R\$117, e, por fim, a Emef com apenas R\$73. O CEI também foi a escola que utilizou o maior valor aluno/ano, R\$ 39, em 2008. A Emef gastou o menor valor aluno/ano, em 2008, com apenas R\$ 7. Em 2006, a Emef teve a maior aplicação do ano, com $\mathrm{R} \$ 16$ por aluno/ano em relação às outras escolas.

A fim de investigar as razões e a dinâmica dos gastos e os procedimentos decisórios com relação a estes, à diretora da Emef foi perguntado: há gastos imprescindíveis para a escola, que o conselho não pode decidir em contrário? Como vocês lidam com essa questão? A diretora da Emef diz:

O que nos guia aqui para levantar as prioridades? Projeto político pedagógico. A gente está sempre se reportando ao projeto político pedagógico. Esse projeto que a gente vem desenvolvendo, vai desencadear mais ações esse ano e, para essas ações, a gente precisa suprir de material. Então, por exemplo, está dentro do meu projeto pedagógico: Identidade e cidadania, formando protagonista. Uma das ações protagonistas bacanas que a gente fez o ano passado foi a reativação do Projeto Rádio na escola.

E, ao reativar a rádio, eu tive que ter toda uma previsão de recursos para aplicar na rádio. Fiz toda a manutenção, adquiri material. Agora, a rádio que foi um sucesso o ano passado, a participação dos alunos foi bastante importante e grande, esse ano ela já requer de manutenção periódica. Então, ela vai virar custo fixo. [...] Só que o projeto é uma ação que está dentro do projeto pedagógico da escola. Então, se a discussão vai para um acirramento, quem decide é o projeto da escola, o que é prioridade dentro do projeto da escola. O projeto da escola tem um trabalho que é feito ao longo do ano, que culmina em um sarau poético. Tem que dar recurso para esse povo trabalhar. Se eu tiver que comprar mais mini system para a sala de aula, para eles ouvirem, se eu tiver que comprar algum livro, se eu tiver que, depois, na hora da apresentação comprar material para eles utilizarem, eu vou ter que comprar. 
$\mathrm{O}$ aluno da Emef participante do CE, na entrevista, disse que decide pelo que é mais urgente, que traria mais benefício para a escola, mas não soube precisar muito bem qual critério se utiliza para resolver os impasses. Ao ser questionado se há tempo antes para pensar nas prioridades, ele respondeu que as coisas eram decididas na hora da reunião e votadas. A mãe da Emef também considera que o que deve ser feito é o mais urgente.

Ao que parece, a escola apresenta muitas demandas emergenciais, o que de certa forma condiciona os gastos. Boa parte delas provém de manutenção predial e adequação de espaços. Por exemplo, uma demanda constatada nos dados das prestações de contas e citado pelos entrevistados com frequência, foi a colocação de cortinas roll-on para fechar o pátio da escola, pois sem estas os alunos ficariam expostos às intempéries climáticas. Essa adequação do prédio requereu um volume considerável de recursos, inclusive foi realizado por etapas, em razão do seu valor.

Ao que parece, não há uma discussão entre pedagógico e não pedagógico. Primeiro, elencam-se as emergências e manutenções, que, geralmente, são os gastos não pedagógicos, e o que sobra é discutido para quais projetos serão gastos ou quais materiais pedagógicos serão comprados.

Sobre isso, foi perguntado à professora da Emef: o que mais conta para você decidir o seu voto, em momentos de decisões difíceis do PTRF, em que há duas propostas, uma ou outra coisa para fazer?

Eu reúno os professores e discuto. Por exemplo, agora, nós estamos numa questão assim com o PTRF. Tem que comprar caixas para o projeto do Educon, caixas de som. Mas eu também estou com um problema seríssimo com as professoras de inglês. Como foi implantada aula de inglês no primeiro ano e inglês no primeiro ano só trabalha com sonoridade elas precisam de televisão. E eu gostaria de colocar, nos primeiros anos, uma televisão em cada sala. Tudo é prioridade, tudo é importante. E as televisões para o primeiro ano também são importantes. E a verba é reduzida. [...] Quem vai abrir mão do quê? Mas quando a situação é difícil, que envolve usar quase toda a verba, eu tenho que sentar com os professores e tirar deles qual é a prioridade que eles têm, no momento.

A fala da professora da Emef ilustra bem a questão. "Quem vai abrir mão do quê?" Então, tiradas as emergências, que projetos serão realizados, quais gastos serão feitos? Essa questão reflete nos números obtidos dos gastos da Emef. Embora nas falas apareça que os gastos são orientados pelo projeto político pedagógico, os gastos pedagógicos vêm depois de sanar as emergências e as manutenções do prédio. Consoante com essa ideia, perguntou-se à funcionária do quadro de apoio: como vocês fazem para decidir quais são as prioridades? Ela 
responde: "É complicado. São muitas. Mas são elencadas as emergenciais, primeiro. [...] Emergenciais vão ser assim, as de estrutura, primeiramente são as emergenciais. Depois, pedagógico. Ambas caminham juntas".

Para os entrevistados da Emei, o bem-estar da criança ganha centralidade. Como exemplo, a mãe da Emei descreve um momento de decisão que ela enfrentou: "Numa eleição democrática, eu optei pelos toldos, porque a reforma do banheiro dos professores seria feita num outro repasse de verba. Mas a prioridade, no meu ponto de vista como mãe, é o bemestar dos alunos." Para a funcionária do quadro de apoio da Emei, também o mais importante na hora de decidir é se vai beneficiar a criança, contudo pondera:

[...] As motocas são importantes para as crianças, mas eles têm outras coisas. Tem parque aqui, tem parque lá em cima [...]. O toldo é prioridade, porque quando venta aqui, venta mesmo, quando chove, chove mesmo. Então, é prioridade isso, vamos dar prioridade. Depois, na outra vez, vamos utilizar outro recurso, vamos ver aquela lâmpada que está queimada, caiu uns reboques ali, e assim vai, tem uma parte do banheiro que emperrou etc.

Para a professora da Emei, o mais importante é a urgência da necessidade. Ela acredita que as despesas com material pedagógico são próximas dos 50\%. A diretora da Emei considera que:

Nunca houve objeção por parte do conselho em termos de utilização dos recursos. Eu acho que existe, inclusive, um entendimento de todos que participam, de que a manutenção tem que ser garantida. A gente, por outro lado, não faz coisas que possam ser consideradas "perfumaria". As principais destinações dos recursos do PTRF nossas são voltadas para o pedagógico. É brinquedo, foi a composição do centro recreativo, foi a montagem e adequação do playground, sempre focados em coisas que revertam para o benefício das crianças. Então, por exemplo, eu estou aqui desde 2005 e desde 2005 nunca se fez pintura geral em salas de aula. Eu poderia ter feito com recursos do PTRF, mas não é prioridade. A prioridade é pedagógica, a prioridade é o atendimento à criança.

Então, essa clareza, eu acho que todos temos de que nós estamos aqui lidando com criança e para fazer um trabalho voltado para um melhor atendimento da criança. Consequentemente, todas as ações voltam sempre para isso, no fórum. Então, isso passa pela questão de organização da linha de tempo, organização dos horários, organização do calendário e destinação dos recursos. Então, o pedagógico acaba sendo sempre prioridade. Para você ter uma noção, em 2005, a gente começou, recebeu o primeiro recurso. Se não me falha a memória, foi só em 2007 que nós começamos a pensar a colocação dessas divisórias aqui no setor administrativo e na sala dos professores, para melhorar a qualidade dos espaços para trabalho nosso. Por quê? Porque antes havia prioridades maiores a serem atendidas, que eram basicamente o quê? A montagem das salas de aula, no que diz respeito aos cantinhos, à composição de todo o acervo de brinquedos que tem nas salas e coisas do tipo. 
As falas afirmam a centralidade nos gastos para as crianças. Contudo, pela análise dos dados coletados das prestações de contas, há duas necessidades classificadas como não pedagógicas que comprometeram parte considerável dos recursos. A primeira foi a necessidade de cortinas roll-on para cobrir o pátio e abrigar os alunos, mesmo sendo uma ação que beneficia diretamente as crianças, foi considerada como adequação do prédio, algo que poderia e deveria ter sido previsto pela prefeitura. A segunda foi a criação de uma miniquadra que, conforme critério adotado, foi considerada adequação do prédio e não equipamento dos espaços.

Nas falas dos membros da comunidade escolar do CEI aparece a centralidade dos recursos para beneficiar as crianças. Para a mãe do CEI, a maior preocupação é com o bemestar das crianças. Para ela, o que conta mais na hora de decidir é "a importância da coisa e a qualidade que ela vai trazer. Então, se tiver que arrumar os banheiros ou comprar um brinquedo, seria arrumar os banheiros a prioridade". Ao ser questionada se a escola gasta muito em manutenção, a mãe relata:

\footnotetext{
Sim, porque é muita criança e, normalmente, banheiro, coisas que caem e quebram. E a manutenção mesmo dos brinquedos, que falta parafuso, aí quebra. Você não vê um brinquedo quebrado. É muito difícil, [as crianças] não usarem porque está quebrado. Deu problema, vai lá e arruma. Você não vê essa escassez de coisa. A criança estar na sala, porque não tem outra coisa para fazer.
}

Então, mesmo a mãe do CEI apontando que a manutenção do prédio, para ela, vem em primeiro lugar, reconhece que há um cuidado com o material pedagógico e, de certa forma, que este não é escasso.

No depoimento da diretora do CEI, ela conta sobre a dinâmica da escola e que se pauta por atender o que é mais urgente.

A escola, como a gente fala, é viva. Então, as necessidades vão aparecendo diariamente. A gente tem o cuidado de ir anotando tudo o que a gente precisa, desde parafuso, porta que está caindo, vidrinho que quebrou, todas as coisas a gente elenca. Quando a gente vai para a discussão, a gente já tem uma pauta imensa de necessidades da unidade. Em conjunto, a gente decide o que é mais urgente, [...] para que a gente possa deixar o que é menos necessário para depois. Por exemplo, no final do ano, a gente decidiu que ia dar um upgrade na unidade. Desde que o CEU foi construído, ele passou por duas reformas, mas elas não contemplaram pintura de parede. Então, as paredes estavam muito desgastadas. E o professor, o educador, ele fica preocupado com essa coisa da beleza, do estético, para que fique mais agradável. Então, a gente decidiu que faria a pintura. A gente conseguiu pintar toda a unidade. Essa pintura foi feita com a mão de obra de gente da unidade, a gente precisa comprar a tinta e ainda pagou uma pessoa para fazer algumas coisas 
bonitas na pintura. Segundo passo é o conserto de armários. Então, a gente foi elencando para que todos se sintam contemplados, senão dá uma guerra danada.

Pelo relato, nota-se que as demandas ainda são focadas na manutenção predial. Mas a diretora do CEI complementa dizendo que a maior parte da manutenção é feita com os recursos do adiantamento bancário e que "a grande maioria [dos recursos do PTRF] é para o pedagógico. Agora, se precisa, temos que usar o PTRF, porque senão o prédio começa a deteriorar".

Considerando os dados orçamentários das escolas e as falas da comunidade escolar, a manutenção predial e as adequações dos espaços são as principais demandas de gastos das escolas. Embora todas as escolas tenham declarado que utilizam os recursos de adiantamento bancário para cobrir os gastos com manutenção, estes não são suficientes e acabam comprometendo os recursos do PTRF também. Assim, percebe-se que o gasto com pedagógico depende do que resta dos gastos com manutenção e adequações dos espaços. Então, se sobra mais recursos, se gasta mais com o pedagógico, por conseguinte, se sobra menos, se gasta menos.

Também pesa o número de alunos que frequentam os espaços. Assim, a Emef, por atender um número grande de alunos, necessita de realizar manutenção com mais frequência e, por isso, tem um gasto percentual e real maior com manutenção e menor com o pedagógico.

\subsection{O que pensa a comunidade sobre o PTRF}

Neste item, a pesquisa pretende verificar o que pensa a comunidade escolar sobre o PTRF, no intuito de levantar informações acerca de uma das condições essenciais que Bobbio (2009) considerou para a aceitação de uma definição mínima de democracia, a condição real para decidir, para isso realizou-se um leque de perguntas para os membros da comunidade escolar.

Ao serem questionados sobre as condições para a tomada de decisões sobre a utilização dos recursos financeiros do programa, os entrevistados membros do CE e da APM 
(aluno, mãe, professora e funcionária do quadro de apoio) das três escolas disseram ter condições para decidir.

Para as diretoras das três escolas, foi perguntado se todos os segmentos da comunidade escolar teriam condições para decidir sobre o PTRF. Para a diretora do CEI, a maior dificuldade de acompanhar é a dos pais, devido à falta de participação. Ela considera que os docentes, por fazerem o acompanhamento no cotidiano e nas tomadas de decisão, têm maiores condições para participar.

\begin{abstract}
Os pais ainda não entendem muito, mas porque eles não participam. Se eles participassem exatamente de todas as reuniões, eles começariam a compreender o processo. Os professores têm. Tanto têm, que todas as compras que nós, aqui no CEI, fazemos, todas as reformas, tudo o que a gente faz aqui é decidido em coletivo. Até porque se não for decidido em coletivo, a cobrança vem para mim também. Então eu não posso arcar com toda a responsabilidade do funcionamento da unidade sozinha. Eu tenho que ter a parceria dos segmentos. Senão, eu não vou conseguir fazer uma boa administração e eles vão estar sempre cobrando de mim uma nova postura. Eles sabem. E a gente vai sempre dando o retorno: - Olha, isso aqui que vocês pediram está aqui, o que vocês pediram está aqui. E a gente procura focar tudo no pedagógico. Desde que o PTRF chegou, o nosso propósito é: -Enquanto pudermos, focaremos no pedagógico. Isso está sendo possível, tanto que todos os brinquedos estão aí, cadernos, é parque, é pintura. (DIRETORA DO CEI)
\end{abstract}

A diretora da Emei explicita a necessidade de esclarecimento aos membros do CE e da APM e exemplifica um recurso que utiliza para tentar resolver esse problema.

\begin{abstract}
Existe uma preocupação quando a gente vai e leva para uma reunião a discussão sobre recursos, de elucidar para todos exatamente o que é. Porque existem terminologias específicas. Quem está chegando não entende. Então, existe o cuidado de esclarecer o que é custeio, o que é capital, o que pode com um, o que pode com outro, o que é PTRF, o que são recursos próprios, o que é adiantamento bancário, que são as três verbas com as quais lidamos. [...] Mas, ao mesmo tempo, eu percebo que para muitos, fica uma coisa ainda meio distante, porque você inclusive apresenta uma ordem de valores que ultrapassa e muito a média de recursos que eles administram no próprio orçamento. Eu tenho o cuidado, inclusive, de trazer comparações mais concretas para que eles possam entender. Por exemplo, decidiu-se uma prioridade, a reposição de material pedagógico em sala, que é basicamente brinquedos. [...] Então, vamos fazer uma compra de brinquedo para as dez salas, às vezes, chega-se a $R \$ 6$ mil ou $R \$ 7$ mil. Na hora que você vai fazer a apresentação das contas, o pai olha: - Nossa, mas tudo isso em brinquedo? A gente tem o cuidado de trazer para um universo mais concreto para eles. -Vamos pensar o seguinte, são $R \$ 7$ mil de compras de brinquedo, mas isso para dez salas. Em torno de $R \$ 700$. Pensando que 35 crianças fazem uso desse brinquedo, você está gastando $R \$ 20$ por criança. [...] Assim, ele chega a uma coisa um pouco mais concreta, com elementos para comparações e entende aquilo.
\end{abstract}

A diretora da Emef considera que, hoje, a comunidade escolar possui condições para discutir o programa, mas ressalta que foi um processo de aprendizado. 
Tem sim. [...] Hoje eles têm mais clareza. Essa discussão já vem acontecendo há bastante tempo, eles já vêm percebendo o que é viável, o que não é viável. Essa questão de que R\$ 12 mil parece muito, mas não é em um universo como um prédio. Eles já estão bastante conscientes, têm uma participação bastante consciente. Eles participam direitinho, com muita clareza. Os alunos inclusive. (DIRETORA DA EMEF)

Todos os entrevistados, ao serem questionados diretamente se possuíam as condições para decidir sobre o PTRF, respondem afirmativamente. Contudo, com o intuito de aprofundar mais a questão, foram feitas outras perguntas, para buscar mais informações sobre a condição para tomar as decisões sobre os recursos do programa. A saber: como a você é informado sobre os recursos financeiros que a escola tem ou receberá? Quais procedimentos são utilizados para elencar as necessidades da escola? E como vocês fazem para decidir quais são as prioritárias?

Os entrevistados foram unânimes em dizer que são informados nas reuniões do CE e/ou da APM. A mãe do CEI conta que também é informada na reunião de pais; a professora da Emei relata que é informada nas reuniões pedagógicas e a funcionária do quadro de apoio da Emef menciona que os recursos são publicados em Diário Oficial.

Sobre os procedimentos para levantar as necessidades, as professoras e as funcionárias do quadro de apoio das três escolas contam que são realizadas consultas internas e que registram também as demandas que vão surgindo no cotidiano. As mães entrevistadas relatam que a discussão é feita diretamente nas reuniões do CE e da APM. A mãe da Emei descreve o procedimento da seguinte forma:

\footnotetext{
Dentro da reunião do Conselho são colocadas as prioridades. A escola traz o que os professores falam nas reuniões de grupo, qual a necessidade da escola, de material pedagógico, tudo... E dentro do Conselho são levantados mais alguns pontos, equipamentos que esteja precisando. Então, é feita uma ata de prioridades para gastos das verbas.
}

Observa-se que o processo é pautado pelas demandas apresentadas pelos docentes e pela gestão da escola. Inclusive, ao perguntar para a professora da Emef se os pais traziam demandas para as escolas, ela diz:

$\mathrm{Na}$ reunião pedagógica, nós levantamos com os professores quais são as necessidades para aquele ano. Depois, essa lista é levada para a reunião do Conselho. E aí, ela é divulgada no Conselho, de como vai ser feito, quais são as prioridades e os pais participam mediante essas prioridades, porque eles acreditam que quem tem mais noção de onde vai ser gasta a verba são os professores que trabalham na unidade. 
As mães contam que decidem na própria reunião, com base no que é levantado pela escola e que, poucas vezes, trazem sugestões.

Foi questionado também sobre a participação dos alunos. A diretora da Emef diz que o procedimento é comunicar aos representantes de sala, para que eles discutam com sua turma e levem para o Conselho. $\mathrm{O}$ aluno da Emef entrevistado conta que eles decidem na própria reunião e que, às vezes, levam propostas para o Conselho; usa o projeto da rádio como um exemplo. No caso do CEI, eles consideram que as crianças são muito pequenas ( 0 a 3 anos) e que os pais as representam. Contudo, quando questionada se consultava a filha para saber o que queria que a escola comprasse ou fizesse, a mãe do CEI respondeu: "A gente conversa sim, mas de comprar ou fazer, não. Ela fala do que já tem, pergunto pra ela se é usado, aqui como é muito grande, se ela vai pro cinema, se ela brinca no escorregador novo, se chegou algum brinquedo novo."

A diretora da Emei, sobre essa questão, diz:

Com as crianças não. É uma discussão que nós estamos travando. Eu sei de experiências exitosas em várias unidades da rede que trabalham com isso. E a gente, inclusive, discutiu na reunião de organização desse ano, da possibilidade de realizarmos os conselhinhos. Tem uma Emei aqui da região que adota isso, tem os representantes de turmas, e periodicamente faz reunião com eles que são os chamados os conselhinhos. Mas aqui não, aqui a gente não tem feito consulta às crianças.

Considerando os depoimentos, a participação dos segmentos de responsáveis e de alunos ainda tem alguns limites a ultrapassar. Somente a diretora da Emei fez uma reflexão sobre os limites do processo de levantamento das prioridades e aponta uma possibilidade para interferir na questão. É preciso pensar em como fazer a discussão de forma a ampliar a participação e não ficar refém das demandas cotidianas. Isso não significa que essas demandas são indevidas ou não legítimas, mas devem-se considerar formas para intensificar a participação dos pais e alunos para que esses se tornem cada vez mais sujeitos dentro da comunidade escolar.

Questionou-se também se eles acreditavam que o fato de a escola receber os recursos financeiros da prefeitura (o PTRF) os motivou a participar dos espaços de decisão da escola. Dos entrevistados, consideraram que o programa as incentivou a participar a mãe do CEI, a mãe da Emef, a funcionária do quadro de apoio da Emei e a funcionária do quadro de apoio da Emef, esta ainda diz que "incentiva bastante saber para onde o dinheiro é gasto". 
O aluno da Emef, a professora da Emei, a professora da Emef, a funcionária do quadro de apoio do CEI, a diretora da Emei, a diretora da Emef consideraram que o fato de a escola receber os recursos do PTRF não foi um motivador para a participação. A mãe da Emei afirmou:

Pela verba, eu acho que não. A verba, em si, acho que não motiva. Motiva, assim, no fato da manutenção da escola e da qualidade do ensino, o material pedagógico e esse tipo de coisa. Mas participar, acho que parte mais de um lado pessoal de querer estar envolvida dentro da vida da escola.

Embora a mãe da Emei tenha dito que não a motivou, relata a importância de ver os resultados de ter esses recursos e aplicá-los na melhoria da escola. A professora do CEI diz que incentiva também a participação, mas que participaria, mesmo se não houvesse o recurso. Já a diretora do CEI julga que o recurso é um facilitador. "Eu acho que ele é um facilitador, na medida em que a comunidade pode participar da prioridade, da prestação de contas e que é um direito do cidadão. Mas mesmo sendo um facilitador, eu ainda acho que falta a consciência da população".

Benevides (1994) considera que a cidadania se aprende na prática. Nesse sentido, as mães entrevistadas e o aluno da Emef foram indagados se tiveram algum aprendizado com a participação na APM e/ou no CE, com relação aos recursos financeiros. Todos responderam que sim, e o aluno conta que aprendeu a decidir quais são as prioridades e o que é emergencial. A mãe da Emef relata que achava que tudo vinha de fora e que a escola não participava dessas decisões e completa dizendo: "Agora eu sei como é gasto o dinheiro que vem, as reformas". A mãe da Emei ressalta a importância da transparência na utilização dos recursos públicos.

\footnotetext{
A gente aprende. Como já trabalhava com administrativo, então já vivia mexendo com isso. É importante ver, eu não sei se acontece só aqui, [mas] todas as reuniões que eu participei, a unidade, a clareza, o lidar com o dinheiro público, você vê pelas pessoas, pelos líderes que estão à frente disso, os presidentes de APM ou do Conselho Administrativo, você vê a clareza e a transparência. Então, você termina aprendendo, você vê que a ética é o melhor trabalho, principalmente com as pessoas que mexem com o dinheiro público.
}

A mãe do CEI diz que, após participar das reuniões do CE e da APM, tem noção das demandas da escola e que é possível trazer experiências de outras escolas e implementar naquela. 
$\mathrm{Na}$ tentativa de descobrir as possibilidades de interferência do PTRF no trabalho pedagógico das escolas, foi perguntado aos entrevistados se os recursos financeiros do programa facilitam ou atrapalham a escola a realizar projetos. Todos consideram que o fato de a escola possuir recursos financeiros para gerir é positivo. A mãe da Emei também julga que os recursos possibilitam a garantia do bem-estar das crianças na escola.

Facilita, com certeza. Porque aí seria mais difícil, por exemplo, você arrecadar uma verba dessas pra fazer um brinquedo, colocar os toldos de proteção, renovar talher, as bandejas que eles usam no self-service, tudo isso. Mesmo a prefeitura mandando, é uma coisa que quebra muito fácil, então tem que repor o tempo inteiro. Para que eles tenham esse bem-estar, a verba vem bem a calhar mesmo.

A professora da Emei destaca ainda a possibilidade de conseguir material e equipamentos para o trabalho pedagógico: "o parque, quando a gente começou aqui, não tinha metade dos brinquedos que tem. Então, ajudou muito sim".

Ao fazer a mesma pergunta para a funcionária do quadro de apoio da Emef, embora ela julgue que o projeto político pedagógico seja uma questão somente das reuniões de Projeto Especial de Ação $\left(\mathrm{PEA}^{21}\right.$ ), detalha algumas ações do projeto político pedagógico da escola.

Como eu te disse, nos PEAs eu não participo. Eu não sei o que acontece lá dentro. Mas nessa parte eu não sei se consigo responder. Por exemplo, como aquela casinha, a gente usava no Projeto Emoções. Tem crianças que têm dificuldade de relacionamento. [A gente] leva assistência para a criança, tem a casinha, ela vai brincar, ela vai mostrar como ela age na casa dela, tem os bonecos, que ela coloca o sorriso, a boca de tristeza. Tinha um menino aqui que ele pegava o menino e socava muito. Hoje ele está no primeiro ano já. Mas através desses brinquedos, que a gente acha que não têm tanta importância, têm sim, às vezes, como a criança que tem problemas em casa, por exemplo, o menino apanhava muito ou batia muito também. Através de brincadeiras, você traz o boneco para a criança, a criança demonstra o que ela vive, a vivência dela.

A diretora da Emef ressalta a importância das escolas possuírem recursos financeiros para o desenvolvimento de atividades.

\begin{abstract}
Ajuda muito, ajuda muito. Nossa, se não fosse o PTRF a gente estava perdida, atualmente. Às vezes eu penso assim: - Como a gente viveu sem? Como viveu tanto tempo sem? O projeto pedagógico da escola é capaz de fazer muita coisa quando você tem recurso. É entender que as coisas da escola não podem ficar só no plano das ideias e das boas intenções. [...] Eu preciso de material, eu preciso de recurso, eu preciso de ambiente, eu preciso de um monte de coisa.
\end{abstract}

\footnotetext{
${ }^{21}$ Elaborado e discutido em reuniões de trabalho coletivo dos professores que estão na Jornada Especial Integral de Formação (Jeif): 25 horas-aula e 15 horas adicionais, sendo que oito são destinadas às reuniões.
} 
Então, sem dúvida nenhuma, deu para a gente fazer várias coisas a partir do PTRF, que, antigamente, ficava no plano das ideias e dos voluntarismos, das boas ações, das doações.

A diretora da Emei também concorda que os recursos financeiros do programa ajudam na realização das atividades, possibilitando que a escola tenha o material adequado para trabalhar. Contudo, ela destaca que, por outro lado, o programa traz um rol de atividades burocráticas, que lhe faz perder um tempo que poderia ser aplicado para a organização e melhoria do trabalho pedagógico. "A burocracia que acompanha a manutenção de uma APM, toma de mim, que no caso faço a gestão direta disso, um tempo enorme" (DIRETORA DA EMEI). Nesse mesmo sentido, a diretora do CEI diz:

\begin{abstract}
Ajuda, na medida em que a gente consegue contemplar a aquisição de recursos que vão realmente implementar todo o projeto pedagógico da escola. A organização dos espaços, por exemplo, é imprescindível para a Educação Infantil. Não tem como não ter a aquisição desses brinquedos, desses recursos, de todas essas coisas para funcionar. Atrapalhar, acho que a burocracia atrapalha. $\mathrm{O}$ excesso de burocracia demanda muito tempo de quem vai prestar contas. Esse prestador de contas, na verdade, sou eu, é o diretor. Então, eu acabo perdendo duas semanas inteiras com PTRF, preocupada, faz conta, refaz conta, acho que isso é uma coisa que atrapalha, a burocracia.
\end{abstract}

Embora sejam necessários alguns cuidados na utilização do dinheiro público, para garantir a transparência e uso para fim do bem comum, devem-se verificar formas de organizar esse processo sem desviar a escola da sua função primeira, que é a educação.

Retomando a discussão já apresentada neste trabalho sobre a necessidade de utilizar a APM como unidade executora dos recursos, pelos dados levantados, verificamos que as escolas realizam um número de reuniões e têm incumbências jurídicas excessivas, decorrentes de manter uma entidade auxiliadora. Inclusive, as escolas-campo desta pesquisa optaram, em alguns momentos, por realizar reuniões em conjunto entre APM e CE, com o intuito de reduzir o desgaste de ter dois espaços de tomada de decisão. Lembrando que as APMs já funcionaram como instrumento de instalação de uma "cidadania sob controle" no período da ditadura militar (SPOSITO, 2000)

Essas informações remetem à questão do tipo de descentralização que o PTRF atende. Do ponto de vista administrativo, percebe-se que essa transferência de incumbências exonera os órgãos centrais e onera as escolas de algumas obrigações. Assim, nota-se um esforço maior de desafogar a administração central do que estabelecer a construção da autonomia das escolas. 
A fim de examinar o que Barroso (1996) chamou de autonomia decretada e o desenvolvimento cotidiano da autonomia escolar, foi perguntado para as professoras entrevistadas se os recursos financeiros provenientes do PTRF ajudavam ou atrapalhavam a autonomia da escola. Todas as professoras disseram que ajudavam, por dar condições de obter materiais para desenvolver trabalhos e projetos. Apontam, no entanto, que atrapalham em relação aos prazos curtos para a realização dos recursos e sua prestação de contas. A professora da Emef também considera que atrapalha a divisão dos recursos por categorias econômicas de capital e custeio (a Emef foi uma das escolas que solicitaram alteração dos percentuais destinados).

Apesar do roteiro de entrevistas não contemplar diretamente a questão da autonomia para as funcionárias, as mães e o aluno, as falas trazem a ideia de que o programa trouxe facilidades para as escolas. As dificuldades, para os entrevistados, eram mais direcionadas à insuficiência de recursos e não da impossibilidade de executar algum gasto ou de tomar certa decisão.

As diretoras concordam que os recursos contribuem com a autonomia das escolas, pois possibilitam maior agilidade e condições para se desenvolver o trabalho pedagógico nas escolas. Por outro lado, elas ponderam que os procedimentos para a utilização e a respectiva prestação de contas, de certa forma, atrapalham a autonomia das escolas.

Pelas falas se evidencia a importância do programa para o cotidiano escolar no desenvolvimento das suas atividades e para implementar seus projetos. Contudo, é impossível negar que o PTRF traz para as escolas atribuições e tarefas complexas das quais não há pessoas habilitadas, ou com conhecimentos para sua realização ou despendem o tempo e trabalho que a gestão teria para garantir a atividade fim das escolas. 


\section{CONSIDERAÇÕES FINAIS}

Ao longo desta dissertação, buscou-se examinar a questão da gestão democrática e sua relação com a gestão financeira das escolas. Também, tentou-se fazer a discussão da necessidade desses dois elementos para a construção de uma educação pública de qualidade, socialmente referenciada. Para tanto, foi-se in locus analisar como as escolas veem os recursos financeiros que são a elas transferidos e o processo de tomada de decisão e execução. Assumiu-se como premissa a de que gestão democrática é um processo e não um estado ou algo em si, que pode ser posta ou transportada. Assim, o desenvolvimento das tomadas de decisão de forma coletiva e participativa é que revela os valores afins da gestão democrática. Paro (2003) afirma que a distribuição do poder concentrado no Estado possibilita o processo de democratização social e, por isso, há resistência a esse movimento.

Ao fim deste trabalho, que se espera instigue outros, têm-se alguns elementos a serem considerados. Em relação ao financiamento da educação, nota-se que os recursos transferidos para as escolas são insuficientes. Ao se observar os cálculos propostos por Carreira e Pinto (2007) para o CAQi, percebe-se que os valores que o PTRF destina para as escolas são insuficientes para o desenvolvimento dos projetos políticos pedagógicos das escolas. $\mathrm{O}$ problema se agrava, ao se considerar que os recursos financeiros do programa também devem cobrir as despesas de manutenção dos prédios. O CAQi considera o valor de R \$100/aluno-ano para o desenvolvimento de projetos de ação pedagógicas para todos os tipos de escolas. Contudo, o maior valor registrado na despesa em pedagógico foi de apenas R $\$ 39 /$ aluno-ano, em 2008 pelo CEI, valor muito inferir ao que o CAQi sugeri. A pesquisa de campo confirmou essa hipótese ao revelar pelos dados da execução das despesas e pelas entrevistas que as necessidades das escolas são superiores às receitas disponíveis e que há necessidades emergenciais que obrigam as instituições a adotarem a política do "apagar incêndio".

Os recursos do PTRF não assumem a mesma taxa de crescimento dos recursos da educação. Enquanto as despesas com MDE assumem, em 2010, uma taxa de crescimento de $26 \%$ em relação ao ano de 2006, as despesas com o PTRF registram uma taxa de apenas $1 \%$. Inclusive, no ano de 2009, a taxa de crescimento das despesas com o PTRF é de $-3 \%$, em relação a 2006. Então, a progressiva autonomia de gestão financeira das escolas, prevista na LDB/96, anda a passos lentos, quando não recuam. Evidentemente, não se espera que 
simplesmente aumentem-se os recursos transferidos. Não se trata apenas de uma redivisão dos recursos financeiros, mas sim do quanto é necessário para se garantir uma educação pública e de qualidade. Assim, é necessário que as receitas destinadas para a educação sejam maiores e, portanto, permitam que as escolas recebam recursos suficientes para a implementação de seus projetos político pedagógicos. Logo, este trabalho também corrobora com os estudos que apontam a necessidade do Brasil investir na educação como uma prioridade de fato.

Outro elemento importante a ser considerado é o dos espaços de tomada de decisão na rede municipal de ensino de São Paulo. Encontra-se na legislação que "o Conselho de Escola é um colegiado com função deliberativa e direcionada à defesa dos interesses dos educandos e das finalidades e objetivos da educação pública do Município de São Paulo" (SÃO PAULO, 2007). Então, a instância máxima de decisão das escolas municipais é o Conselho de Escola. Nesse sentido, também é definido que compete ao Conselho de Escola: “[...] decidir procedimentos relativos à priorização de aplicação de verbas” (SÃO PAULO, 2007).

Entretanto, pela legislação que regulamenta os trâmites do PTRF, as APMs são incumbidas da responsabilidade pelos recursos e da definição de sua destinação. Não por acaso, sabe-se que na rede municipal de ensino de São Paulo, confirmado por alguns dos depoimentos das entrevistas, está presente o pensamento de que as questões financeiras são tratadas pela APMs e as outras questões, como o pedagógico, pelo Conselho de Escola.

Como se sabe, a participação não é uma questão simples. Hipoteticamente essa cultura de dividir as atribuições da APM de do CE podem ser usadas para manipular as tomadas de decisão. Por exemplo, um diretor que julgar ter mais poder de influência na diretoria de APM chamará as reuniões dessa entidade para tomar as decisões sobre os recursos.

Outro aspecto importante, ao pensar na coexistência desses dois espaços de tomada de decisão, está no trabalho, tempo e disponibilidade dos membros da comunidade em participar. O fato de haver dois espaços de decisão requer mais reuniões e isso esbarra na disposição dos membros em participar. Dessa forma, o segmento que possui mais condições de estar presente leva vantagem. Pelo fato de as reuniões acontecerem no espaço da escola e, por vezes, serem realizadas durante a jornada de trabalho dos servidores, estes acabam tendo maior presença.

Então, deve-se fazer o questionamento: é necessário ter o Conselho de Escola e a APM funcionando nas escolas? À luz do princípio da gestão democrática, a coexistência de dois espaços de tomada de decisão não ajuda o processo de democratização da educação. Pode-se pensar que, com a existência de dois espaços com representantes da comunidade, 
haveria mais pessoas participando, assim atendendo um dos elementos que Bobbio (2009) elencou como necessário para uma definição mínima de democracia. Contudo, sabe-se que por vezes a mesma pessoa está nos dois espaços, pois é difícil encontrar pessoas dispostas a participar. Outro problema está relacionado à proporcionalidade, na medida em que as APMs não a tem entre os membros da comunidade escolar. Não por acaso em algumas escolas optase por realizar reuniões conjuntas para reduzir o número de reuniões e aumentar a participação, porém preservando o problema da desproporcionalidade nos espaços de tomada de decisão.

Como descrito nesta dissertação, há outras formas de descentralizar recursos para as escolas sem a necessidade da constituição de uma APM, como a proposta defendida por Polo (2001) de utilização do adiantamento bancário ou como o caso do município de Santo André que tornar os CE em pessoa jurídica. É de suma importância fortalecer o Conselho de Escola como instância máxima de deliberação e mecanismo de democratização da educação. A legislação não deve dar margem para interpretações que questionem a legitimidade deste órgão.

Ao longo desta pesquisa, teve-se também a preocupação de observar se era assegurado à comunidade escolar condições reais para decidir, atendendo a outro critério essencial para a democracia, segundo Bobbio (2009). Dada a insuficiência dos recursos, as escolas acabam por apresentar uma dinâmica de estabelecer as prioridades para as despesas, de acordo com o que é mais emergencial.

Trazer para a escola a responsabilidade da decisão, se será feito a troca de lâmpadas queimadas, por exemplo, não é democrático. Pelo contrário, como demonstrado pelos depoimentos e dados levantados, incumbir a escola de decidir por fazer uma manutenção em detrimento de outras atividades pedagógicas é precarizar ainda mais o ensino público, com o agravante de responsabilizar a comunidade escolar por fazer essa escolha, quando na verdade não há escolha. Ou melhor, há uma escolha do poder público em relegar às escolas condições precárias e inapropriadas de funcionamento e tratar essa questão como problema exclusivo das escolas e não como uma política de sucateamento do ensino público.

As receitas que as escolas recebem do PTRF apresentam um leque muito grande de itens de naturezas distintas para cobrir. Os recursos financeiros transferidos têm que cobrir despesas com atividades-meio, como adquirir material de expediente para a secretaria, parte do material de limpeza, manutenção do prédio e, o que é mais oneroso, fazer as adequações de espaço físico do prédio. É evidente que essas necessidades são muito importantes para o 
andamento das escolas, mas acaba condicionando as tomadas de decisões e as necessidades de despesas com a atividade-fim das escolas ficam em último lugar.

Neste trabalho, foi também realizado o exercício de buscar classificar as despesas com pedagógico e com o não pedagógico. Embora seja complexo delimitar essa divisão, os resultados mostraram que as despesas com pedagógico foram secundarizadas. Apenas o CEI conseguiu realizar gastos em maior volume nessa modalidade do que em não pedagógico. Evidenciou-se também que os recursos do CEI não são suficientes para realizar grandes mudanças, pois receberam um montante muito inferior aos das outras escolas.

$\mathrm{Na}$ análise da regulamentação do PTRF, viu-se que com a Portaria 1845/2006 há uma tentativa de determinar que, no mínimo, 50\% dos recursos do PTRF fossem utilizados no “desenvolvimento de atividades educacionais e na implementação de projetos pedagógicos da Unidade Educacional" (SÃO PAULO, 2006b). Essa exigência, no entanto, persistiu por apenas três meses, e a sua revogação revela que as atividades educacionais não são o foco dessa política.

A determinação de um percentual para ser gasto pelas escolas com atividades pedagógicas cumpre papel importante de garantir que as escolas utilizem ao menos esse percentual. A pesquisa revelou como é importante para a escola possuir recursos para desenvolver suas atividades, entretanto a execução das prioridades ainda é reativa às emergências do cotidiano escolar. Assim, determinar um mínimo, ou mesmo separar os recursos para despesas com pedagógico, garante a aplicação dos recursos na atividade-fim das escolas sem depender das sobras, após atender as despesas com emergências, com a manutenção do prédio, com expediente de secretaria, entre outras.

Também se observou na pesquisa de campo, que está muito presente nas falas dos membros do Conselho de Escola ou APM e mesmo da direção das escolas, a questão dos requisitos burocráticos para a utilização da verba do PTRF. Como os recursos descentralizados para as escolas são dinheiro público, é necessário estabelecer o controle social. Contudo, há no PTRF uma contradição, na medida em que estabelece procedimentos para as escolas realizarem as despesas com o mesmo rigor e procedimentos de órgãos centrais, contrariando a justificativa da descentralização em dinamizar e agilizar a realização das despesas. As escolas devem prestar contas? Com certeza, sim! Entretanto, deve-se lembrar qual é a função social da escola, que é educar. Para se exigir o rigor burocrático para a 
utilização desses recursos é necessário também dar condições técnicas e garantir um quadro suficiente de servidores para realizar essa tarefa.

Hoje, a estrutura das escolas, em termos de recursos humanos e tecnológicos, não dá conta das exigências do programa. Exemplo disso encontrou-se na pesquisa de campo: montantes consideráveis de recursos que não foram gastos, não porque as necessidades já haviam sido supridas, mas pelas dificuldades com os trâmites burocráticos para a realização dos gastos.

Os problemas foram surgindo durante a existência do programa e isso se evidencia também nas suas constantes alterações. É fundamental que haja canais de comunicação entre escola e SME para minimizar esses problemas. Um espaço que poderia cumprir esse papel seria os Creces, que também possibilitariam a formação dos conselheiros.

É interessante notar que nas escolas que fizeram parte da pesquisa apenas uma tinha na pauta do Conselho de Escola a questão da formação dos membros do conselho. A formação política dos conselheiros é fundamental para a compreenderem a função social do conselho e que o espaço tem potencial de interferir nos rumos dos trabalhos das escolas e assim construir uma educação de qualidade. Há a necessidade de pensar um processo pedagógico de construir uma cultura de participação no interior das escolas e fomentar que essa cultura transpasse destas para a sociedade (AGUIAR, 2000).

A formação dos conselheiros se mostra também importante, porque os procedimentos para execução dos recursos são muito complexos e, às vezes, por falta de domínio dos trâmites burocráticos, as escolas têm dificuldades em executar as despesas. Como as escolas, na maioria dos casos, não dão conta das demandas burocráticas do PTRF têm contratado serviços contábeis de terceiros (os recursos do programa podem ser gastos com essa despesa, mas isso significa de antemão comprometer parte dos recursos, independentemente das prioridades estabelecidas). Logo, se é para proceder com os trâmites burocráticos da mesma forma que os órgãos centrais e intermediários seria preferível não descentralizar os recursos, pois nesses órgãos há profissionais técnicos que poderiam assim o fazer. Inclusive, nos órgãos intermediários e centrais ainda há a necessidade de pessoas para fiscalizarem e orientarem a execução dos recursos. Outra possibilidade é ampliar o quadro de servidores nas escolas, oferecer formação técnica para os conselheiros e garantir maior suporte nos órgãos centrais e intermediários.

Uma situação frequentemente encontrada na relação das escolas com os órgãos intermediários ou centrais é que quando a primeira solicita orientações são apresentadas as 
proibições para a realização dos gastos e não qual forma se deve proceder para garantir a execução da despesa e fazer valer a decisão coletiva e democrática da escola.

Resta, então, uma questão: descentralizar recursos financeiros para as escolas ou não?

Primeiramente, é necessário relembrar que a descentralização não é um fim em si mesma e também não é natural a nenhum marco ideológico. Ela busca chegar a determinado fim, por isso, deve-se observar a que fim esse mecanismo está sendo utilizado (ROVERSI, 1992; CASASSUS; 1995). Adotou-se para esta dissertação a definição do termo descentralização na sua forma mais genérica de distribuição de atividades/funções/atribuições centralizadas para o âmbito local.

Portanto, descentralizar, ou não descentralizar, depende dos propósitos dessa ação. Com todos os problemas revelados pela pesquisa sobre o PTRF, nas escolas acredita-se que o fato de possuírem recursos financeiros para gerir é fundamental para o funcionamento das instituições.

Contudo, deve-se ter o cuidado para que a descentralização não se torne uma desresponsabilidade do Poder Público.

É preciso, entretanto, estar atento para, com relação à autonomia administrativa, não
confundir descentralização de poder com "desconcentração" de tarefas; e, no que
concerne à gestão financeira, não identificar autonomia com abandono e
privatização. [...] É preciso principalmente se contrapor a esse movimento que, com
o discurso da autonomia - e da necessidade de participação da comunidade e
passagem do controle das escolas às mãos da sociedade civil -, o que está se fazendo
é justificar medidas tendentes a eximir o Estado de seu dever de arcar com os custos
das escolas, com solução que deixam-nas à própria sorte, induzindo participação da
comunidade, não para decidir sobre seus destinos, mas para contribuir no
financiamento do ensino. (PARO, 2002, p. 83-84)

Embora existam inúmeras armadilhas e ambiguidades sobre a questão da descentralização de recursos financeiros, indiscutivelmente há um ganho muito importante quando se pensa que mais pessoas estão discutindo o dinheiro público. O orçamento público, que por vezes é "público" somente na sua arrecadação, passa a ser público, de fato, quando a mãe, o aluno, a professora, a merendeira e outros começam a discutir sua origem e seu destino.

Cabe destacar a definição de democracia de Coutinho (2000) como valor universal. Valor porque enriquece o homem em qualquer de suas esferas (do trabalho, da socialização, da universalização, da consciência e da liberdade) e universal porque existe em diferentes organizações econômico-sociais, mesmo na sociedade capitalista por meio da luta da classe 
160

trabalhadora. Assim, as oportunidades de ampliação da participação e a formação da população na construção da cidadania são fundamentais para a busca da transformação da nossa sociedade em uma mais justa e igualitária. 


\section{Referências Bibliográficas}

ADRIÃO, Theresa; CAMARGO, Rubens Barbosa. A gestão democrática na Constituição Federal de 1988. In: OLIVEIRA, Romualdo Portela; ADRIÃO, Theresa. (org) Gestão, financiamento e direito à educação: análise da LDB e da Constituição Federal. São Paulo: Xamã, $2^{a}$ ed., 2002.

AGUIAR, Márcia Angela da S. Gestão da Educação e a Formação do Profissional da Educação no Brasil. In: FERREIRA, Naura Syria Carapeto; AGUIAR, Marcia Angela da S. (orgs.) Gestão da educação: impasses, perspectivas e compromissos. $3^{a}$ ed. São Paulo: Cortez, 2000.

ARRETCHE, Marta. Estado federativo e políticas sociais: determinantes da descentralização. São Paulo: FAPESP, 2000.

BARROSO, João. Estudo da Autonomia da Escola: da Autonomia Decretada à autonomia Construída. In: BARROSO, João (org.). O Estudo da Escola. Porto: Porto editora, 1996.

BENEVIDES. Maria Vitoria. Cidadania e Democracia. Lua nova, São Paulo: CEDEC, n. 33, 1994.

BOBBIO, Norberto. O futuro da democracia: uma defesa das regras do jogo. $11^{\text {a }}$ Ed. São Paulo: Paz e Terra, 2009.

BRASIL. Constituição (1934). Constituição da República dos Estados Unidos do Brasil, de 16 de Julho de $1934 . \quad$ Disponível <http://www.planalto.gov.br/ccivil_03/constituicao/constitui\%C3\%A7ao34.htm> acesso em 18/07/2011.

Lei Federal no 4.320, de 17 de março de 1964. Estatui Normas Gerais de Direito Financeiro para elaboração e controle dos orçamentos e balanços da União, dos Estados, dos Municípios e do Distrito Federal. Diário Oficial da União, Brasília, DF, 23/03/1964.

Lei Federal $n^{\circ} 7.398$, de 04 de novembro de 1985. Dispõe sobre a organização de entidades representativas dos estudantes de $1^{\circ}$ e $2^{\circ}$ graus e dá outras providências. Disponível em <http://www.planalto.gov.br/ccivil/LEIS/L7398.htm> acesso em 27/03/2011. 
Constituição Federal (1988). Constituição da República Federativa do Brasil, promulgada em 05 de Outubro de 1988. São Paulo: Imprensa Oficial, 2001.

. Lei Federal no 9.394, de 20 de dezembro de 1996. Estabelece as diretrizes e bases da educação nacional (LDB). Diário Oficial da União, Brasília, DF, 23 dez. 1996.

Medida Provisória ${ }^{\circ}$ 1.784, de 14 de dezembro de 1998. Diário Oficial da União, Brasília, DF, 15/12/1998.

. Lei Complementar Federal $n^{\circ}$ 95, de 26 de fevereiro de 1998. Diário Oficial da União, Brasília, DF, 27/02/1998.

. Medida Provisória n ${ }^{\circ}$ 2.178-36, de 24 de agosto de 2001. Diário Oficial da União (edição extra), Brasília, DF, 25/08/2001.

Constituição (1988). Emenda Constitucional no 53, de 19 de dezembro de 2006. Diário Oficial da União, Brasília, DF, 09/03/2006.

. Lei Federal $n^{\circ} 11.494$, de 20 de junho de 2007. Regulamenta o Fundo de Manutenção e Desenvolvimento da Educação Básica e de Valorização dos Profissionais da Educação - FUNDEB, de que trata o art. 60 do Ato das Disposições Constitucionais Transitórias; altera a Lei $\mathrm{n}^{\mathrm{O}}$ 10.195, de 14 de fevereiro de 2001; revoga dispositivos das Leis $\mathrm{n}^{\text {OS }} 9.424$, de 24 de dezembro de 1996, 10.880, de 9 de junho de 2004, e 10.845, de 5 de março de 2004; e dá outras providências. Diário Oficial da União, Brasília, DF, 21/06/2007.

- Ministério da Educação. Manual de orientação para constituição de unidades executoras. Brasília, DF, 2009a.

. Lei Federal n ${ }^{\circ} 11.947$, de 16 de junho de 2009. Diário Oficial da União, Brasília, DF, $17 / 06 / 2009.2009 b$

BUENO, Belmira A. B. Oliveira Bueno. Associações de pais e mestres na escola publica do estado de São Paulo: 1931-1986. 1987. 319 f. Tese (Doutorado em Educação) - Faculdade de Educação, Universidade de São Paulo, São Paulo, 1987.

CAMARGO, Rubens Barbosa de. Gestão Democrática e Nova Qualidade de Ensino: O conselho de Escola e o Projeto da Interdisciplinaridade nas Escolas Municipais da 
Cidade de São Paulo. 1997. 370 f. Tese (Doutorado em Educação) - Faculdade de Educação, Universidade de São Paulo, São Paulo, 1997.

CASASSUS, Juan. A Centralização e a Descentralização da Educação. Cadernos de Pesquisa, São Paulo, n. 95, p. 37-42, nov., 1995.

Descentralización de la gestión a las escuelas y calidad de la educación: mitos o realidades? In: COSTA, V. L. C. (org.,). Descentralização da educação: novas formas de coordenação e financiamento. São Paulo, Fundap/Cortez, 1999, p. 13-31.

COUTINHO, Carlos Nelson. Contra a corrente - ensaios sobre democracia e socialismo. São Paulo: Cortez, 2000.

CRETELLA JÚNIOR, José. Direito Administrativo. São Paulo: Bushatsky; Ed. da Universidade de São Paulo, 1973.

CRUZ, Silvia Helena Vieira. "A gente não quer só comida", falam as crianças. In: CAMPOS, Maria Malta; CRUZ, Silvia Helena Vieira. Consulta sobre qualidade da educação infantil: o que pensam e querem os sujeitos desse direito. São Paulo: Cortez, 2006.

CRUZ, Rosana Evangelista. Pacto Federativo e Financiamento da Educação: a função supletiva e redistributiva da União - o FNDE em destaque. 2009. 406 f. + anexos. Tese (Doutorado em Educação) - Faculdade de Educação, Universidade de São Paulo, São Paulo, 2009.

CURY, Carlos Roberto Jamil. Os conselhos de educação e a gestão dos sistemas. In: FERREIRA, N. S. C.; AGUIAR, M. A. da S. (orgs.) Gestão da educação: impasses, perspectivas e compromissos. São Paulo: Cortez, 2000.

DA MATTA, Roberto. Cidadania: a questão da cidadania num universo relacional. In: DA MATTA, Roberto. A casa \& a rua: espaço, cidadania, mulher e morte no Brasil. Rio de Janeiro: Guanabara, $4^{\text {a }}$ ed. 1991

FERREIRA, N. S. C. Gestão democrática da educação: ressignificando conceitos e possibilidades. In: FERREIRA, N. S. C.; AGUIAR, M. A. da S. (orgs.) Gestão da educação: impasses, perspectivas e compromissos. São Paulo: Cortez, 2000. 
FISCHMANN, Roseli. Estrutura administrativa da Secretaria Municipal de Educação da Prefeitura do Município de São Paulo: um estudo de fatores condicionantes. Estudos e Documentos, São Paulo: Faculdade de Educação da Universidade de São Paulo, nº 29, 1988.

GOUVEIA, Andréa Barbosa. Esquerda e direita na política municipal: um estudo sobre a administração do PFL em Curitiba e do PT em Londrina. Curitiba: HonorisCausa Editora, 2010.

LUZ, Liliene Xavier. Conselhos escolares: cidadania, participação e gestão democrática na educação? Teresina: EDUFPI, 2000.

MACHADO, Lourdes Marcelino. Autonomia administrativa, financeira, poder local e políticas educacionais: uma análise a partir de artigos de Anísio Teixeira. MARTINS. A. M.; OLIVEIRA, C. de; BUENO, M. S. S. (orgs.). Descentralização do Estado e municipalização do ensino: problemas e perspectivas. Rio de Janeiro: DP\&A, 2004.

MARCONI, Marina de Andrade; LAKATOS, Eva Maria. Técnicas de Pesquisa: planejamento e execução de pesquisas, amostragens e técnicas de pesquisas, elaboração, análise e interpretação de dados. São Paulo: Atlas, 1996.

MARTINS, Angela Maria. Autonomia da escola: a (ex)tensão do tema nas políticas públicas. São Paulo: Cortez, 2002.

MELO, Maria Tereza Leitão de. Gestão educacional: os desafios do cotidiano escolar. In : FERREIRA, N. S. C.; AGUIAR, M. A. da S. (orgs.) Gestão da educação: impasses, perspectivas e compromissos. São Paulo: Cortez, 2000.

PARO, Vitor Henrique. Escritos sobre educação. São Paulo: Xamã, 2001.

O princípio da gestão democrática no contexto da LDB. In: OLIVEIRA, Romualdo P.; ADRIÃO, Theresa. (orgs). Gestão, financiamento e direito à educação: análise da LDB e da Constituição Federal. São Paulo: Xamã, $2^{a}$ ed., 2002.

Eleição de Diretores: a escola pública experimenta a democracia. São Paulo: Xamã, $2^{a}$ ed., 2003.

Educação como exercício do poder: crítica ao senso comum em educação. São Paulo: Editora Cortez, 2008. 
PEPE, Theresa Maria de Freitas Adrião. Gestão Democrática nas Escolas da Rede Municipal de São Paulo 1989-1992. 1995. 154 f. Dissertação (Mestrado em Educação) Faculdade de Educação, Universidade de São Paulo, São Paulo, 1995.

PERONI, Vera M. V. Financiamento da escola à luz do novo papel do Estado: o caso do Rio Grande do Sul. Revista Brasileira de Política Administração da Educação. Porto Alegre, v.22, n.2, p. 331-344, jul./dez. 2006.

POLO, José Carlos. Planejamento e orçamento no município. In: RODRIGUES, M. M.; GIÁGIO. Guia de consulta para o programa de apoio aos secretários municipais de educação - PRASEM III. Brasília: FUNDESCOLA/MEC, 2001.

RIVAS, Ricardo Hevia. Política de descentralización en la educación básica y media en América Latina: Estado del Arte. Santiago, Chile: UNESCO/ REDUC, 1991.

RODDEN, Jonathan. Federalismo e descentralização em perspectiva separada: sobre significados e medidas. Revista de Sociologia e Política, Curitiba, 24, p. 9-27, jun., 2005.

ROVERSI, Fabio. Descentralização e centralização. BOBBIO, N.; MATTEUCCI, N.; PASQUINO,G. Dicionário de Política. Brasília: Editora Universidade de Brasília, $4^{\mathrm{a} e d, ~ v .1, ~}$ 1992.

SANTO ANDRÉ, Lei Municipal no 8.376, de 27 de Junho de 2002. Altera a Lei $\mathrm{n}^{\circ} 7.854$, de 30 de Junho de 1999, que constitui do Conselho de Escola nas unidades escolares do município de Santo André. Diário do Grande ABC, Pag. 05, 28/06/2002. Disponível em

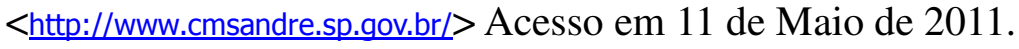

Lei Municipal $n^{\circ} 8.805$, de 16 de Dezembro de 2005. Autoriza a celebração de convênio entre o município de Santo André e os Conselhos de Escola.Diário do Grande ABC no 12.715, Pág. 4, 17/12/2005. Disponível em <http://www.cmsandre.sp.qov.br/> Acesso em 11 de Maio de 2011.

SÃO PAULO (Município). Decreto-Lei $n^{\circ} 430$, de 8 de julho de 1947. Disponível em $<$ http://camaramunicipalsp.qaplaweb.com.br/iah/fulltext/decretoslei/DLEI0430-1947.pdf>, acessado em 18/07/2011.

Lei $\mathrm{n}^{\circ}$ 10.513, de 11 de maio de 1988. Diário Oficial [da] Cidade de São Paulo. São Paulo, SP, 12/05/1988, Folha 1. 
- Lei $\mathrm{n}^{\text {o }}$ 11.229, de 26 de junho de 1992. Disponível em $<$ http://camaramunicipalsp.qaplaweb.com.br/iah/fulltext/leis/L11229.pdf $>, \quad$ acessado em $18 / 07 / 2011$

Lei Orgânica do Município, de 04 de abril de 1990. Disponível em $<$ http://www.camara.sp.gov.br/images/stories/legislacao/Lei-Organica-2009-10-01.pdf> Acesso em 27/03/2011.

Projeto de Lei $n^{\circ}$ 119/2000. Diário Oficial [da] Cidade de São Paulo. São Paulo, SP, 07/04/2000, Folha 55.

. Projeto de Lei no 47/2001. Diário Oficial [da] Cidade de São Paulo. São Paulo, SP, 17/02/2001, Folha 34 .

Projeto de Lei $n^{\circ}$ 155/2002. Diário Oficial [da] Cidade de São Paulo. São Paulo, SP, 22/03/2002, Folha 60. 2002a.

. Comissão de Constituição e Justiça. Parecer $n^{\circ}$ 888/2002. Diário Oficial [da] Cidade de São Paulo. São Paulo, SP, 29/06/2002. 2002b.

. Comissão de Administração Pública. Parecer nº 1.220/2003. Diário Oficial [da] Cidade de São Paulo. São Paulo, SP, 11/09/2003.

Comissão de Educação, Cultura e Esportes. Parecer $n^{\circ}$ 1.539/2003. Diário Oficial [da] Cidade de São Paulo. São Paulo, SP, 31/10/2003.

. Decreto $\mathrm{n}^{\mathrm{o}}$ 46.230, de 23 de agosto de 2005. Diário Oficial [da] Cidade de São Paulo. São Paulo, SP, 24/08/2005, Folha 02. 2005a

. Comissão de Finanças e Orçamento. Parecer s $/ n^{\circ}$. Diário Oficial [da] Cidade de São Paulo. São Paulo, SP, 17/05/2005. Plenário, p. 104. 2005b.

Lei $\mathrm{n}^{\mathrm{o}}$ 13.991, de 10 de junho de 2005. Institui o Programa de Transferência de Recursos Financeiros às Associações de Pais e Mestres das Unidades Educacionais da Rede Municipal de Ensino. Diário Oficial [da] Cidade de São Paulo. São Paulo, SP, 11/06/2005, Folha 01. 2005c.

Razões de Veto Projeto de Lei $n^{\circ}$ 155/2002. Diário Oficial [da] Cidade de São Paulo. São Paulo, SP, 15/06/2005 Folha 3. 2005d. 
Portaria da Secretaria Municipal de Educação nº 6.475. Diário Oficial [da] Cidade de São Paulo. São Paulo, SP, 04/10/2005, Folha 15.

Portaria da Secretaria Municipal de Educação nº 6.686. Diário Oficial [da] Cidade de São Paulo. São Paulo, SP, 19/10/2005, Folha 16.

Portaria da Secretaria Municipal de Educação n ${ }^{\circ}$ 6.889. Diário Oficial [da] Cidade de São Paulo. São Paulo, SP, 10/11/2005, Folha 20.

. Portaria da Secretaria Municipal de Educação no 2810. Diário Oficial [da] Cidade de São Paulo. São Paulo, SP, 29/06/2006, Folha 13. 2006a.

Portaria da Secretaria Municipal de Educação $\mathrm{n}^{\circ}$ 1.845. Diário Oficial [da] Cidade de São Paulo. São Paulo, SP, 30/03/2006, Folha 20. 2006 b.

Portaria da Secretaria Municipal de Educação n 819. Diário Oficial [da] Cidade de São Paulo. São Paulo, SP, 11/02/2006, Folha 16.

Portaria da Secretaria Municipal de Educação no 2.254. Diário Oficial [da] Cidade de São Paulo. São Paulo, SP, 11/05/2006, Folha 21.

Portaria da Secretaria Municipal de Educação nº 2.990. Diário Oficial [da] Cidade de São Paulo. São Paulo, SP, 29/06/2006, Folha 13.

Portaria da Secretaria Municipal de Educação nº 2.991. Diário Oficial [da] Cidade de São Paulo. São Paulo, SP, 29/06/2006, Folha 13.

Decreto n ${ }^{\circ}$ 47.837, assinado dia 31 de outubro de 2006. Diário Oficial [da] Cidade de São Paulo. São Paulo, SP, 01/11/2006, Folha 01.

Portaria da Secretaria Municipal de Educação no 4.351. Diário Oficial [da] Cidade de São Paulo. São Paulo, SP, 07/11/2006, Folha 16.

- Lei $\mathrm{n}^{\mathrm{o}}$ 14.660, de 26 de dezembro de 2007. Disponível em $<$ http://camaramunicipalsp.qaplaweb.com.br/iah/fulltext/leis/L14660.pdf>, acessado em 18/07/2011. 2007a. 
. Portaria da Secretaria Municipal de Educação $n^{\circ} 1.876$. Diário Oficial [da] Cidade de São Paulo. São Paulo, SP, 08/03/2007, Folha 12. 2007 b.

- Portaria da Secretaria Municipal de Educação no 3.887. Diário Oficial [da] Cidade de São Paulo. São Paulo, SP, 19/07/2007, Folha 13.

Portaria da Secretaria Municipal de Educação no 3.615. Diário Oficial [da] Cidade de São Paulo. São Paulo, SP, 30/06/2007, Folha 18.

. Portaria da Secretaria Municipal de Educação $n^{\circ}$ 4.450. Diário Oficial [da] Cidade de São Paulo. São Paulo, SP, 28/08/2007, Folha 12.

Portaria da Secretaria Municipal de Educação n ${ }^{\circ}$ 5.678. Diário Oficial [da] Cidade

de São Paulo. São Paulo, SP, 21/12/2007, Folha 19.

. Lei $\mathrm{n}^{\circ}$ 14.660, de 26 de dezembro de 2007. Diário Oficial [da] Cidade de São Paulo. São Paulo, SP, 27/12/2007, Folha 05.

. Portaria da Secretaria de Finanças/ SUTEM nº 07. Diário Oficial [da] Cidade de São Paulo. São Paulo, SP, 30/03/2007, Folha 17.

. Portaria da Secretaria Municipal de Educação no 4.554. Diário Oficial [da] Cidade de São Paulo. São Paulo, SP, 12/11/2008, Folha 16. 2008a.

. Secretaria Municipal de Educação. Assessoria Técnica e de Planejamento. Procedimentos para aplicação dos repasses referentes ao Programa de Transferência de Recursos Financeiros - PTRF à rede municipal de ensino de São Paulo. São Paulo, 2008.

Portaria da Secretaria Municipal de Educação n ${ }^{\circ}$ 1.505. Diário Oficial [da] Cidade de São Paulo. São Paulo, SP, 14/03/2008, Folha 20.

. Portaria da Secretaria Municipal de Educação n ${ }^{\circ}$ 421. Diário Oficial [da] Cidade de São Paulo. São Paulo, SP, 02/12/2008, Folha 12.

- Portaria da Secretaria Municipal de Educação no 1.758 . Diário Oficial [da] Cidade de São Paulo. São Paulo, SP, 05/03/2009, Folha 16. 
Portaria da Secretaria Municipal de Educação no 2.251. Diário Oficial [da] Cidade de São Paulo. São Paulo, SP, 04/04/2009, Folha 11.

. Portaria da Secretaria Municipal de Educação no 4.023. Diário Oficial [da] Cidade de São Paulo. São Paulo, SP, 22/08/2009, Folha 16.

Portaria da Secretaria Municipal de Educação no 2001. Diário Oficial [da] Cidade de São Paulo. São Paulo, SP, 26/03/2010, Folha 15. 2010a.

Portaria da Secretaria Municipal de Educação no 3.664. Diário Oficial [da] Cidade de São Paulo. São Paulo, SP, 08/07/2010, Folha 08.

SILVA, Pedro Luiz Barros \& MELO, Marcus André Barreto de. O Processo de implementação de políticas públicas no Brasil: características e determinantes na avaliação de programas e projetos. Caderno $\mathbf{n}^{\mathbf{0}} 48$ no NEPP- Núcleo de Estudos de Políticas Públicas. Universidade de Campinas, 2000.

SILVA, Maria Vieira. Gestão Democrática na Educação: as contribuições e omissões da LDB (Lei 9.394/96). In: SILVA, M. V. \& MARQUES, M. R. A.(org.). LDB: balanços e perspectivas para a educação brasileira. Campinas: Alínea, 2008.

SOUZA, Ângelo Ricardo. Reformas educacionais: descentralização, gestão e autonomia escolar. In Educar. Editora UFPR, Curitiba, n. 22, p. 17-49, 2003.

SOUZA, Ângelo Ricardo. O Financiamento da Educação na Escola: Análise dos Recursos Disponíveis em 13 Escolas Públicas no Estado do Paraná. GOUVEIA, A. B.; SOUZA, A. R.; TAVARES, T. M.(orgs.). Conversas sobre Financiamento da Educação no Brasil. Curitiba: Ed. UFPR, 2006.

SPÓSITO, Marília Pontes. Educação, gestão escolar e qualidade do ensino: o que os pais ou responsáveis têm a ver com isso? In: BASTOS, João Baptista (org). Gestão Democrática. Rio de Janeiro: DP\&A editora, 2000.

TEIXEIRA, Anísio. Educação para a Democracia: introdução à administração. Rio de Janeiro: Editora UFRJ, 1997, $2^{\text {a }}$ Ed.

THE WORLD BANK. What is School-Based Management? Washington, DC. Novembro de 
$<$ http://siteresources.worldbank.org/EDUCATION/Resources/278200-

$1099079877269 / 547664-1099079934475 / 547667-1145313948551 /$ what_is_SBM.pdf $>$.

Acesso em 15/12/2009.

WEBER, Max. Conceitos básicos de sociologia. São Paulo: Centauro, 2002. 


\section{ANEXOS}

Anexo A: Número de escolar por tipo e por faixa de alunos

\begin{tabular}{|c|c|c|}
\hline TIPO DE ESTABELECIMENTO & $\begin{array}{c}N^{0} \text { DE } \\
\text { ESCOLAS }\end{array}$ & $\%$ \\
\hline \multicolumn{3}{|l|}{ CEI } \\
\hline DE 1 ATÉ 200 ALUNOS & 302 & $85 \%$ \\
\hline ACIMA DE 201 ALUNOS & 10 & $3 \%$ \\
\hline \multicolumn{3}{|l|}{ CEI (CEU) } \\
\hline DE 1 ATÉ 500 ALUNOS & 45 & $13 \%$ \\
\hline TOTAL & 357 & $100 \%$ \\
\hline \multicolumn{3}{|l|}{ EMEI } \\
\hline DE 1 ATÉ 400 ALUNOS & 300 & $59 \%$ \\
\hline DE 401 ATÉ 800 ALUNOS & 159 & $31 \%$ \\
\hline ACIMA DE 801 ALUNOS & 3 & $1 \%$ \\
\hline \multicolumn{3}{|l|}{ EMEI (CEU) } \\
\hline DE 1 ATÉ 500 ALUNOS & 21 & $4 \%$ \\
\hline DE 501 ATÉ 1000 ALUNOS & 25 & $5 \%$ \\
\hline TOTAL & 508 & $100 \%$ \\
\hline \multicolumn{3}{|l|}{ EMEF } \\
\hline DE 1 ATÉ 800 ALUNOS & 171 & $31 \%$ \\
\hline DE 801 ATÉ 1500 ALUNOS & 292 & $54 \%$ \\
\hline DE 1501 ATÉ 2200 ALUNOS & 27 & $5 \%$ \\
\hline ACIMA DE 2201 ALUNOS & 1 & $0 \%$ \\
\hline \multicolumn{3}{|l|}{ EMEF (CEU) } \\
\hline DE 501 ATÉ 1000 ALUNOS & 22 & $4 \%$ \\
\hline DE 1001 ATÉ 2000 ALUNOS & 23 & $4 \%$ \\
\hline \multicolumn{3}{|l|}{ EMEFEM } \\
\hline DE 1 ATÉ 800 ALUNOS & 1 & $0 \%$ \\
\hline DE 801 ATÉ 1500 ALUNOS & 5 & $1 \%$ \\
\hline DE 1501 ATÉ 2200 ALUNOS & 2 & $0 \%$ \\
\hline TOTAL & 544 & $100 \%$ \\
\hline \multicolumn{3}{|l|}{ EMEE } \\
\hline DE 1 ATÉ 250 ALUNOS & 4 & $67 \%$ \\
\hline DE 251 ATÉ 350 ALUNOS & 2 & $33 \%$ \\
\hline TOTAL & 6 & $100 \%$ \\
\hline \multicolumn{3}{|l|}{ CIEJA } \\
\hline DE 501 ATÉ 1000 ALUNOS & 12 & $86 \%$ \\
\hline DE 1001 ATÉ 2000 ALUNOS & 2 & $14 \%$ \\
\hline TOTAL & 14 & $100 \%$ \\
\hline \multicolumn{3}{|l|}{ CECI } \\
\hline DE 1 ATÉ 500 ALUNOS & 3 & $100 \%$ \\
\hline TOTAL & 3 & $100 \%$ \\
\hline TOTAL GERAL & 1432 & \\
\hline
\end{tabular}

Fonte: elaborada pelo autor com base nos dados no site da SME $<$ http://eolgerenciamento.prefeitura.sp.gov.br/frmgerencial/NumerosCoordenadori a. $\operatorname{aspx}$ ?Cod $=000000>$, acessado em 22/03/2011 
Anexo B: Exemplo de atas escaneadas ou fotografadas.

parabenizanam o traballuo de todos da EMEF. Ogradecendo a todos a Prof.'

encerrou a reuniato, solvicitando aule fosse lawrada ata, por mim a

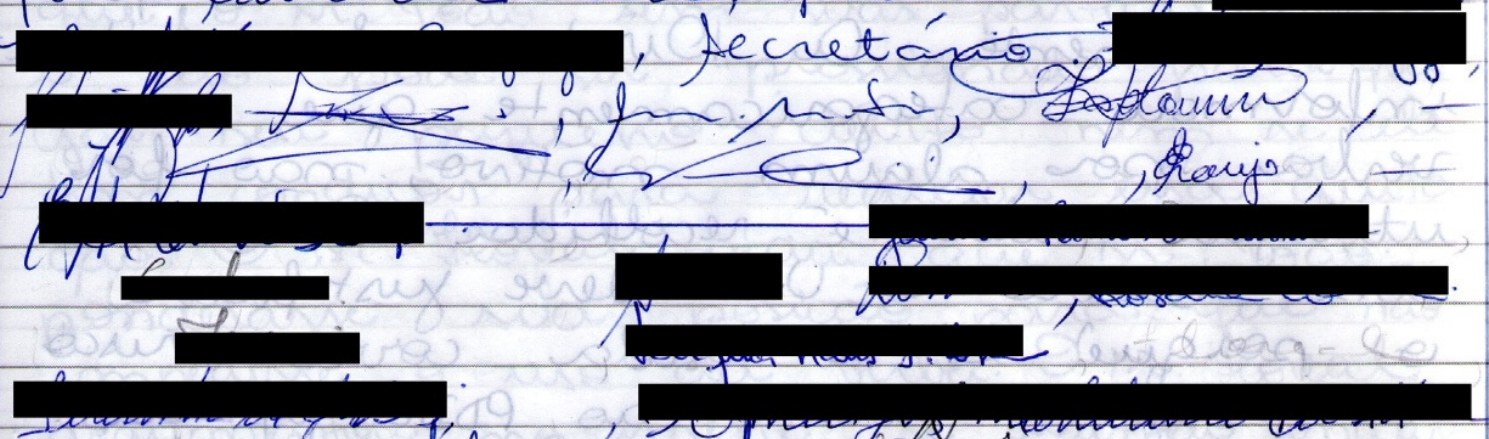

Cos dez dias do mis de novembro realizorse a Reunião Sndinainia da APM. Form contactados todos as membros ellitos da APM e a comunidade tamberm foi notificada. A Profa. iniciou a reuniöo explicando a verba do PDDE detalhadomente (valores i inLensíes) e do PTRF da mesma forma. A Dinetora sra chegou de numiäo ma C.E. trazendo a reguinte informagáo listagem das prioridodes de gastos da verba PDDE que deve ner feita neparadamente do PTRF. Ela informa que a pontin desta data $10 / 11$ a verba fá está disponínel pl uso. a hir lla. explicar que todos as itens que forem elencados p/aquinicão, deverão ter selo menos 2 (dois) orgamentos diferenter e deverao ner guardados ma escda, mesmo depos da compra. Orientar tamberm 


\section{Ata da reunião ordinária do Conselho de Escola da Escola Municipal de} Educacão Infantil de 25/11/2009

Aos vinte e cinco dias do mês de Novembro do ano de dois mil e nove, na sala de aula no 01 da EMEI às $19 \mathrm{~h} 00 \mathrm{em}$ primeira chamada, realizouse a reunião ordinária do Conselho de Escola em conjunto com a Diretoria Executiva, Conselho Fiscal da Associação de Pais e Mestres e demais convidados presentes com a seguinte pauta a ser tratada: Prestação de Contas do PTRF de agosto/ setembro; prioridades de gasto para o próximo repasse do PTRF; total arrecadado com a venda de fotos e configuração das salas de aula para 2010. A senhora diretora

iniciou a reunião demonstrando aos presentes como deverá ser a configuração das salas de aula para o ano letivo de 2010 para atender a demanda oriunda do CEI, da demanda e os casos de inclusão: Período da manhã e tarde: salas $1,2,3$ e $4-1^{\circ}$ estágio; salas 4,6 e 8 - 20 estágio; salas 5,7 e $9-30$ estágio, sendo que em um 10 estágios da manhã e três da tarde, um $2^{\circ}$ estágio da manhã e um da tarde haverá inclusão, portanto, solicitaremos redução do número de alunos. Caso apareçam novos casos de inclusão solicitaremos novas reduções, caso seja possível. Devido a nova configuração da escola, ou seja, formação de mais dois 10 estágios, será necessário a adequação dos brinquedos e mobiliário de mais uma sala de aula. Todos os presentes foram favoráveis à configuração e adequações das salas para o ano de 2010. Dando prosseguimento na pauta a senhora diretora apresentou aos presentes a prestação de contas do PTRF dos meses de agosto a novembro, que por unanimidade foi aprovada por todos. Maiores detalhamentos sobre a prestação de conta encontram-se no livro de Ata da APM. A seguir foi exposto aos pais o período de entrega das fotos para as crianças (30/11 a 05/12) e o total depositado na conta de recursos próprios até o dia $18 / 11$ foi de $R \$ 1.192,00$, totalizando em conta um total de $\mathrm{R} \$ 2.298,71$. Finalizando os itens da pauta da reunião foram discutidas e levantadas as prioridades de gastos para o próximo repasse do PTRF, a saber: 10 manutenção do prédio, $2^{\circ}$ pintura de jogos e brincadeiras no parque, 30 adequação das salas dos $1^{\circ}$ estágios, $4^{\circ}$ reposição dos brinquedos pedagógicos, 50 reparo e manutenção das motocicletas, 60 cortinas, 70 almofadas para as salas, $8^{\circ}$ tatames de EVA, $9^{\circ}$ carrinho de carga e $10^{\circ}$ filmadora digital. Esgotados os assuntos, a senhora diretora, Sra

ofereceu a palavra a quem dela desejasse fazer uso e como não houve manifestação agradeceu a presença de todos, considerando encerrada a reunião, a qual eu,

lavrei-a na presente ata, que vai por mim assinada e pelos demais presentes. ${ }_{\text {n }}$ São Paulo 25 de novembro de 2009.

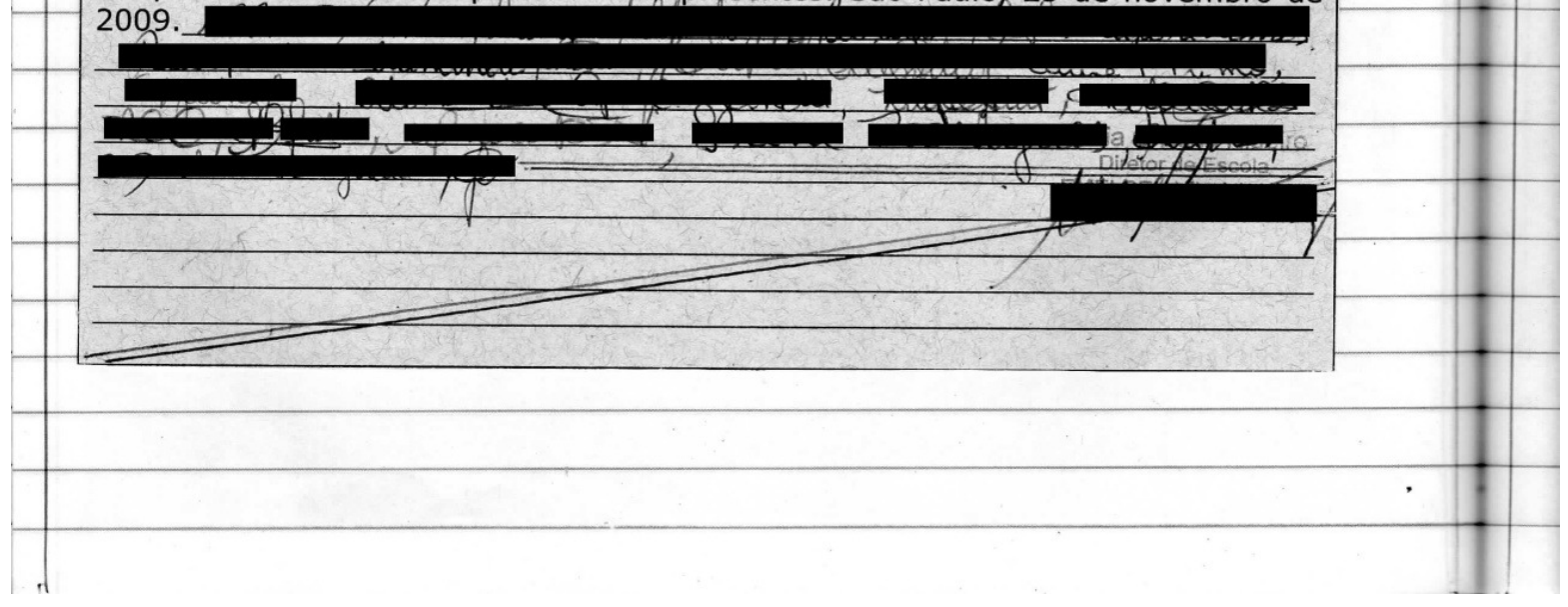

